\title{
Sociaalpsychiatrische verpleegkunde : de ontwikkeling van een verpleegkundig specialisme in het domein van de Nederlandse sociale psychiatrie
}

Citation for published version (APA):

Brouns, G. J. A. M. (2010). Sociaalpsychiatrische verpleegkunde : de ontwikkeling van een verpleegkundig specialisme in het domein van de Nederlandse sociale psychiatrie. [Doctoral Thesis, Maastricht University]. Datawyse / Universitaire Pers Maastricht. https://doi.org/10.26481/dis.20100304gb

Document status and date:

Published: 01/01/2010

DOI:

10.26481/dis.20100304gb

Document Version:

Publisher's PDF, also known as Version of record

Please check the document version of this publication:

- A submitted manuscript is the version of the article upon submission and before peer-review. There can be important differences between the submitted version and the official published version of record.

People interested in the research are advised to contact the author for the final version of the publication, or visit the DOI to the publisher's website.

- The final author version and the galley proof are versions of the publication after peer review.

- The final published version features the final layout of the paper including the volume, issue and page numbers.

Link to publication

\footnotetext{
General rights rights.

- You may freely distribute the URL identifying the publication in the public portal. please follow below link for the End User Agreement:

www.umlib.nl/taverne-license

Take down policy

If you believe that this document breaches copyright please contact us at:

repository@maastrichtuniversity.nl

providing details and we will investigate your claim.
}

Copyright and moral rights for the publications made accessible in the public portal are retained by the authors and/or other copyright owners and it is a condition of accessing publications that users recognise and abide by the legal requirements associated with these

- Users may download and print one copy of any publication from the public portal for the purpose of private study or research.

- You may not further distribute the material or use it for any profit-making activity or commercial gain

If the publication is distributed under the terms of Article 25fa of the Dutch Copyright Act, indicated by the "Taverne" license above, 


\section{Sociaalpsychiatrische verpleegkunde}

De ontwikkeling van een verpleegkundig specialisme in het domein van de Nederlandse sociale psychiatrie 
ISBN 978-90-5278-913-2

C Copyright G Brouns, Maastricht 2010

Layout en druk Datawyse / Universitaire Pers Maastricht Omslagillustratie: Piet Brouns 


\section{Sociaalpsychiatrische verpleegkunde}

De ontwikkeling van een verpleegkundig specialisme in het domein van de Nederlandse sociale psychiatrie

\section{PROEFSCHRIFT}

ter verkrijging van de graad van doctor aan Universiteit Maastricht, op gezag van de Rector Magnificus Prof. Mr. G.P.M.F. Mols

volgens het besluit van het College van Decanen,

in het openbaar te verdedigen

op donderdag 4 maart 2010 om 16.00 uur

door

Gerard Joseph Antonius Maria Brouns

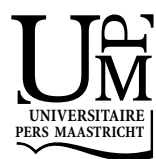




\section{Promotores}

Prof. dr. H. Philipsen

Prof. dr. A. Knotter

\section{Copromotor}

Dr. J.P.M. Diederiks

\section{Beoordelingscommissie}

Prof. dr. L.M.G. Curfs (voorzitter)

Prof. dr. T. Dassen (Charité Universitätsmedizin, Berlin)

Prof. dr. J.P.H. Hamers

Prof. dr. G.I.J.M. Kempen

Dr. W.J.M.J. Rutten (Sociaal Historisch Centrum voor Limburg, Maastricht) 


\section{Inhoud}

$1 \quad$ Introductie 9

1.1 Achtergrond en aanleiding 9

1.2 Sociaalpsychiatrisch verpleegkundigen 11

1.3 Opbouw en indeling van deze studie 12

1.4 Een visie op domeinen, beroepen en professionalisering 15

2 Het ontstaan van de beweging van de sociale psychiatrie: een overzicht tot aan de Tweede Wereldoorlog 21

$2.1 \quad$ Inleiding 21

2.2 Inrichtingspsychiatrie 22

2.2.1 De situatie in de inrichtingen 22

2.2.2 Arbeid in de inrichtingen 25

2.3 Zorg voor psychiatrische patiënten buiten de inrichtingen 26

$2.4 \quad$ Nazorgdiensten 29

$2.5 \quad$ Sociale psychiatrie 30

2.5.1 Duitsland 30

2.5.2 De Verenigde Staten 32

2.5.3 Nederland 34

2.6 Conclusies en discussie $\quad 39$

3 Het ontstaan van het psychiatrisch-sociaal werk in de Verenigde Staten en van de sociaalpsychiatrische verpleegkunde in Nederland 41

3.1 Inleiding 41

3.2 De beroepsmatige verpleegkunde 42

3.2.1 De somatische verpleegkunde 42

3.2.2 De psychiatrische verpleegkunde 44

3.2.2.1 De invloed van de psychiaters 46

3.2.2.2 Het imago van de psychiatrische verpleegkunde 46

3.3 Psychiatrisch-sociaal werk in de Verenigde Staten 49

3.3.1 Het begin 49

3.3.2 De opleiding 50

3.4 Sociaalpsychiatrische verpleegkunde in Duitsland en Nederland 53

3.4.1 Sociaalpsychiatrische verpleegkunde in Duitsland 53

3.4.2 Sociaalpsychiatrische verpleegkunde in Nederland 54

3.4.2.1 Het begin 54

3.4.2.2 De opleiding B-nazorg 57

3.5 Maatschappelijk werkenden in de psychiatrie in Nederland 58

3.6 Conclusies en discussie 59 
$4 \quad$ Vergelijkende analyse en conclusies $\quad 62$

$4.1 \quad$ Inleiding 62

4.2 Het ontstaan van het domein van de sociale psychiatrie 62

4.2.1 De Verenigde Staten 64

4.2.2 Duitsland 65

4.2.3 Nederland 66

4.3 Analyse en conclusies 67

4.4 Terugkoppeling naar de theorie 69

$4.5 \quad$ Vooruitblik 71

5 De ontwikkeling van de sociale psychiatrie en de sociaalpsychiatrische verpleegkunde in Nederland van omstreeks 1940 tot omstreeks $1985 \quad 75$

$5.1 \quad$ Inleiding 75

5.2 Ontwikkelingen in de inrichtingspsychiatrie $\quad 76$

5.3 Ontwikkelingen in de sociale psychiatrie van omstreeks 1940 tot omstreeks 198581

5.4 Van nazorgzuster tot sociaalpsychiatrisch verpleegkundige $\quad 85$

5.4.1 Nazorg en voorzorg 85

5.4.2 Ontwikkelingen in de beroepsopleiding 86

5.4.3 De beroepsvereniging 91

5.5 Conclusies en discussie 92

$6 \quad$ Sociale psychiatrie in de provincie Limburg tot omstreeks 1975: van achterstand tot voorsprong $\quad 97$

$6.1 \quad$ Inleiding 97

6.2 Begin van de psychiatrische nazorg in Limburg 97

6.3 De consultatiebureaus in Limburg 99

6.4 De komst van de nazorgzuster in Limburg 100

6.5 Sociale psychiatrie in de regio Maastricht 102

6.6 Statusonderzoek 104

6.6.1 Aantallen contacten 104

6.6.2 Soorten contacten 105

6.6.3 Inhoud van de contacten 106

6.7 Conclusies en discussie 108

7 Sociaalpsychiatrische verpleegkunde en de beroepsontwikkeling in de periode van omstreeks 1950 tot omstreeks $1985 \quad 113$

$7.1 \quad$ Inleiding 113

7.2 Bronnen 114

7.3 De verpleegkundigen en de patiënten 116 
7.4 De samenwerking van de verpleegkundigen met andere professionals 118

7.5 De opleiding van de verpleegkundigen 121

7.6 De verpleegkundigen en de veranderingen in de gezondheidszorg 125

7.7 De drijfveren van de verpleegkundigen $\quad 130$

7.8 Conclusies en discussie 131

$8 \quad$ Ruim twintig jaar ontwikkelingen in het domein van de geestelijke gezondheidszorg en de sociaalpsychiatrische verpleegkunde van omstreeks 1985 tot $2008 \quad 135$

$8.1 \quad$ Inleiding 135

8.2 Ontwikkelingen in de geestelijke gezondheidszorg 136

8.2.1 Patiëntenstroom 136

8.2.2 Psychotherapie 137

8.2.3 Poliklinieken 138

8.2.4 Biologische oriëntatie 138

8.2.5 Invloed van de overheid 140

8.2.6 Patiëntenbeweging 141

8.2.7 Kritiek 141

8.2.8 Samenwerking 142

8.2.9 Recente ontwikkelingen en plannen 143

8.3 De sociaalpsychiatrische verpleegkunde 145

8.3.1 Groei van de beroepsgroep 145

8.3.2 Werk van de sociaalpsychiatrisch verpleegkundigen 145

8.3.3 Andere verpleegkundigen in het extramurale domein 148

8.3.4 Sociaalpsychiatrisch verpleegkundigen in de eerstelijn 149

8.3.5 Aandacht voor het sociaalpsychiatrische gedachtegoed 150

8.3.6 Het verpleegkundige opleidingslandschap 152

8.4 Conclusies en discussie 153

$9 \quad$ Conclusies en discussie $\quad 160$

9.1 Inleiding 160

9.2 Het ontstaan van het domein van de sociale psychiatrie tot omstreeks 1940160

9.3 De uitgroei van de sociale psychiatrie van omstreeks 1940 tot omstreeks 1985165

9.4 Sociale psychiatrie in de provincie Limburg tot omstreeks $1975 \quad 169$

9.5 De geestelijke gezondheidszorg vanaf omstreeks 1985 tot heden 172

9.6 De sociaalpsychiatrische verpleegkunde vanaf de Riagg-vorming 174

9.7 Terugkoppeling naar de theorie 177

9.9 Methodologische en inhoudelijke kanttekeningen 183

9.10 Tot besluit 185 
Naamgeving van de verpleegkundigen in de sociale psychiatrie door de jaren heen $\quad 187$

Bronnen en literatuur 190

Summary 200

Dank 232

Curriculum vitae $\quad 234$ 


\section{Hoofdstuk 1}

\section{Introductie}

\subsection{Achtergrond en aanleiding}

Op 1 augustus 2006 is de dan goed 2000 leden tellende Nederlandse Vereniging voor Sociaal-Psychiatrisch Verpleegkundigen (NVSPV) opgegaan in de beroepsvereniging Verpleegkundigen en Verzorgenden Nederland (V\&VN). De in 1979 opgerichte NVSPV is daarmee opgehouden te bestaan als zelfstandige vereniging. Ze maakt nu, onder de naam "V\&VN Sociaal-Psychiatrisch Verpleegkundigen" (V\&VN-SPV), deel uit van de koepelorganisatie. Het verenigingstijdschrift Sociale Psychiatrie blijft bestaan. Er bestaat sinds 2003 een register waarin sociaalpsychiatrisch verpleegkundigen zich kunnen laten inschrijven. ${ }^{1}$

Per december 2006 zijn in V\&VN 33 beroepsverenigingen gebundeld met ongeveer 20.000 leden. Deze organisatie kan enerzijds worden beschouwd als een koepel van beroepen, anderzijds als behartiger van de inhoud en de ontwikkeling van de verpleegkundige en verzorgende beroepen in het algemeen. De koepel houdt zich enkel indirect bezig met arbeidsvoorwaarden. ${ }^{2}$ De belangenbehartiging op dat gebied gebeurt door de vakbonden.

Naast de nieuwe beroepsvereniging en verschillende vakbonden bestaat er de beroepsvereniging $\mathrm{Nu}$ '91. Deze richt zich zowel op beroepsinhoud als op arbeidsvoorwaarden en telt zo'n 20.000 leden, zowel verpleegkundigen als verzorgenden. ${ }^{3}$ De beroepsvereniging Sting, enkel voor verzorgenden, heeft een kleine 3000 leden. ${ }^{4}$

Naar schatting twaalf procent van de in totaal ruim 400.000 verpleegkundigen en verzorgenden in Nederland is lid van een beroepsvereniging. ${ }^{5}$

De fusie van 2006 is, naar het zich laat aanzien, een belangrijke gebeurtenis in het ontwikkelingsproces van verpleging en verzorging in Nederland. De toetredende leden geven te kennen dat ze voldoende met elkaar gemeen hebben om belangen en interesses te bundelen in één organisatie. Ze zijn blijkbaar van mening dat er een domein verpleging en verzorging bestaat waarin twee beroepsgroepen actief zijn: de verpleegkundigen en de verzorgenden.

\footnotetext{
${ }^{1}$ www.venvn.nl 30-10-2006.

${ }^{2}$ www.venvn.nl 10-12-2008.

${ }^{3}$ Mededeling ledenadministratie NU'91, 01-12-2008.

${ }^{4}$ www.levv.nl 30-10-2006.

${ }^{5}$ www.venvn.nl 30-10-2006.
} 
Van deze twee groepen heeft de groep verpleegkundigen een bepaalde mate van maatschappelijke erkenning verkregen door opname in het BIG-register. De Wet BIG (Beroepen in de Individuele Gezondheidszorg) van 1993 regelt onder meer de bevoegdheid om een beroep in de individuele gezondheidszorg te mogen uitoefenen. Wie aan de wettelijke opleidingseisen heeft voldaan kan zich laten inschrijven in het register en mag de door de wet beschermde titel verpleegkundige voeren. ${ }^{6}$ Hoewel verzorgende geen beschermde titel is, geldt voor verzorgenden net zoals voor verpleegkundigen dat voor de uitoefening van de werkzaamheden uniforme eisen bestaan, zowel met betrekking tot de opleiding aan erkende onderwijsinstellingen als tot de benodigde praktijkervaring.

Het domein verpleging en verzorging wordt gekenmerkt door grote diversiteit. $\mathrm{Er}$ zijn beroepsbeoefenaren die werken op variërende arbeidsplekken, van zeer medische, op cure georiënteerde afdelingen van ziekenhuizen tot op care georiënteerde omstandigheden zoals de thuiszorg of de verzorgings- en verpleeghuizen. De concrete werkzaamheden variëren met de werkplek van hoog technisch tot basaal verzorgend.

$\mathrm{Er}$ is sprake van wisselende zelfstandigheid in rol en verantwoordelijkheid ten aanzien van de zorgvragers. Verpleegkundigen en verzorgenden die in de periferie van de gezondheidszorg werken, zoals verpleegkundigen in de thuiszorg en gezinsverzorgenden, vormen minder de verlengde arm van de arts dan verpleegkundigen die werken op bijvoorbeeld een afdeling intensieve zorg van een academisch ziekenhuis. $^{7}$

Deze variatie geldt eveneens voor de inhoud en het niveau van de opleidingen. In de Nederlandse verpleging en verzorging werken beroepsbeoefenaren die zijn opgeleid op mbo-, hbo- en universitair niveau. Functiebenamingen variëren van zorghulp, helpende, verzorgende, verpleegkundige, specialistisch verpleegkundige tot verpleegkundig specialist en nurse practitioner. Er is sprake van een groot aanbod in bijscholingsmogelijkheden.

Een laatste punt waarmee de diversiteit kan worden geillustreerd is dat van de organisatiegraad van verpleegkundigen en verzorgenden. Bij V\&VN-SPV is in 2006 met 2070 leden ruim 80 procent van de hele groep aangesloten. Ter vergelijking: V\&VN GGZ-Verpleegkunde telt 236 leden op een geschat totaal van ruim 12.000 psychiatrisch verpleegkundigen. ${ }^{8}$ Dat is net geen twee procent.

\footnotetext{
${ }^{6}$ www.ribiz.nl 01-10-2009. In 2009 zijn 256.435 verpleegkundigen geregistreerd.

${ }^{7}$ Boom, H. van der, Philipsen, H., \& Stevens. F. (2004). Een schets van de professionalisering van de wijkverpleging in Nederland in de laatste vijftig jaar (1950-2004). Gewina, 27, 100-119, 103.

${ }^{8}$ Recentere informatie, uitgesplitst naar de twee genoemde groepen is er niet. V\&VN registreert niet meer naar specialisme. Mededeling ledenservice V\&VN 6-1-2009.

Naar verwachting daalt het ledenaantal van V\&VN-SPV tot onder de 1600 aan het einde van 2008, zo kan worden opgemaakt uit de Toelichting Resultatenrekening 2007 bij het verslag van de Algemene Ledenvergadering mei 2008. http://spv.venvn.nl 1-12-2008.
} 


\subsection{Sociaalpsychiatrisch verpleegkundigen}

De sociaalpsychiatrisch verpleegkundigen hebben, vergeleken met de psychiatrisch verpleegkundigen, niet enkel een hoge organisatiegraad, maar ze zijn ook relatief hoog opgeleid. Volgens een in 2006 uitgevoerde raadpleging van de leden van V\&VN-SPV, heeft 70 procent een opleiding op hbo-niveau (niet nader gespecificeerd) gevolgd en 30 procent de Voortgezette Opleiding (VO). De percentuele verdeling man-vrouw is $42-58$. Tien procent werkt voornamelijk met jeugdigen, 67 procent met volwassenen, inclusief ouderen. Dertien procent werkt met andere cliënten (niet nader omschreven). ${ }^{9}$

Dat de sociaalpsychiatrisch verpleegkundigen, vergeleken met de psychiatrisch verpleegkundigen, een hoog opgeleide beroepsgroep vormen, heeft vooral te maken met het feit dat de groep met de opleiding Maatschappelijke Gezondheidszorg/Geestelijke Gezondheidszorg (MGZ/GGZ) een eigen specialistische beroepsopleiding op hbo-niveau heeft waarvoor het diploma van een verpleegkundige basisopleiding is vereist. De psychiatrisch verpleegkundigen hebben zo'n beroepsopleiding niet; zij kunnen met een basisdiploma, zowel op mbo- als op hbo-niveau, aan de slag. ${ }^{10}$

Wellicht meer nog dan organisatiegraad en niveau van opleiding zijn werkkenmerken typerend voor de sociaalpsychiatrisch verpleegkundigen. Zij zijn merendeels extramuraal actief, met een hoge mate van zelfstandigheid, in multidisciplinaire teams onder eindverantwoordelijkheid van psychiaters. De sociaalpsychiatrisch verpleegkundigen die bij huisartsen werken, doen dat onder verantwoordelijkheid van die huisartsen.

Zowel het werkveld waarin, als de achtergrond van waaruit wordt gewerkt, kunnen worden aangeduid met, zoals later nog zal blijken, de enigszins weerbarstige term sociale psychiatrie. Hoe het ook zij, er is blijkbaar sprake van een domein binnen de gezondheidszorg, meer precies binnen de geestelijke gezondheidszorg, waarop een verpleegkundige beroepsgroep actief is, te weten die van de sociaalpsychiatrisch verpleegkundigen.

Naar de ontwikkeling van de sociaalpsychiatrische verpleegkunde is nog maar weinig onderzoek verricht. Deze studie heeft dan ook als doel het ontstaan en de ontwikkeling van de sociaalpsychiatrische verpleegkunde in Nederland, vanaf haar ont-

\footnotetext{
${ }^{9}$ Ledenraadpleging V\&VN-SPV 2006. Rapport 29-11-2006, Noordam \& De Vries, 11-12.

Het percentage van zeventig is aan de lage kant. Voor een gedeelte kan dat worden verklaard uit het feit dat verpleegkundigen met voortgezette en hogere opleidingen, bijvoorbeeld een VO of een Master, zich niet als HBO-opgeleid beschouwen. Een andere verklaring kan worden gvonden in de tot 1996 vigerende dispensatieregeling van de Inspectie voor de Gezondheidszorg die het mogelijk heeft gemaakt dat niet $\mathrm{HBO}$-opgeleiden toch als sociaalpsychiatrisch verpleegkundige kunnen functioneren.

${ }^{10}$ Met psychiatrisch verpleegkundigen worden hier bedoeld verpleegkundigen die, zonder de opleiding MGZ/GGZ, werkzaam zijn in de psychiatrie.
} 
staan in de jaren twintig van de twintigste eeuw tot omstreeks 1985, in beeld te brengen. Dat gebeurt op basis van drie basale vragen.

- Hoe is in de gezondheidszorg een afzonderlijk domein sociale psychiatrie tot stand gekomen?

- Hoe heeft zich in dit domein een afzonderlijke verpleegkundige beroepsgroep ontwikkeld?

- Valt te verwachten dat in de komende jaren, die gepaard gaan met een (deels al gerealiseerde) aanzienlijke stelselwijziging in zowel de gezondheidszorg als in het onderwijs, de sociaalpsychiatrische verpleegkunde een afzonderlijke beroepsgroep zal blijven?

Aan een studie van de eerste twee vragen is dit proefschrift in hoofdzaak gewijd. De derde vraag zal aan het slot aan de orde worden gesteld in een reflectie op de bevindingen van de studie.

In dit hoofdstuk zal, na de opbouw van de studie, een theoretisch kader worden gepresenteerd dat als uitgangspunt zal dienen voor de analyses in de hoofdstukken daarna.

\subsection{Opbouw en indeling van deze studie}

Tussen dit inleidende en het laatste hoofdstuk bevat deze studie zeven delen die in chronologische volgorde ingaan op de twee eerste vragen.

In hoofdstuk 2 wordt, op basis van literatuuronderzoek, het ontstaan van de beweging van de sociale psychiatrie geschetst. Omdat dat niet goed mogelijk is zonder een idee te hebben van de inrichtingspsychiatrie, wordt daarvan eerst ter inleiding een beeld gegeven. Het hoofdstuk bestrijkt de periode van het begin van de twintigste eeuw, wanneer de term sociale psychiatrie voor het eerst wordt gebruikt, tot aan de Tweede Wereldoorlog. De schets geeft de ontwikkelingen in Duitsland en de Verenigde Staten weer, gevolgd door die in Nederland. De ontwikkelingen in Nederland zijn sterk beïnvloed door die in Duitsland en de Verenigde Staten.

Duidelijk zal worden hoe in de gezondheidszorg, naast de klinische psychiatrie, een afzonderlijk domein sociale psychiatrie ontstaat. In snel en sterk industrialiserende samenlevingen wordt het van belang geacht om psychiatrische patiënten na hun ontslag in hun leefomgeving te begeleiden en om activiteiten te ontplooien waardoor stoornissen en (her)opnames kunnen worden voorkomen. Initiatieven daartoe worden genomen door psychiaters. Zij pogen door het beïnvloeden van de publieke opinie, en met het inschakelen van hulpkrachten, nazorg voor uit de inrichting ontslagen psychiatrische patiënten van de grond te krijgen. In Nederland ontstaat met name omstreeks 1930 een praktijk waarin vanuit psychiatrische inrichtingen, maar ook vanuit stedelijke en provinciale organisaties, verpleegkundigen gaan meewerken aan extramurale psychiatrische spreekuren en huisbezoeken gaan af- 
leggen. Er is weliswaar een specifiek en erkend domein in de gezondheidszorg ontstaan, maar van een afzonderlijke sociaalpsychiatrische beroepsgroep, medisch zowel als verpleegkundig, is dan nog geen sprake. Ook worden de werkzaamheden in dit domein niet of nauwelijks operationeel omschreven.

In hoofdstuk 3 wordt een vergelijking gemaakt tussen de Verenigde Staten en Nederland in ongeveer dezelfde periode als in hoofdstuk 2. Hoewel in beide landen op in grote lijnen overeenkomstige wijze een sociaalpsychiatrisch domein ontstaat, leidt dat tot verschillende ontwikkelingen van daarbij behorende beroepsgroepen. Vanaf het begin van de eeuw worden in de Verenigde Staten maatschappelijk werkenden betrokken bij de extramurale zorg voor psychiatrische patiënten. In Nederland zijn dat, vanaf ongeveer 1920, verpleegkundigen. Beschrijving van beide processen is behulpzaam bij het beantwoorden van de tweede onderzoeksvraag, die luidt: hoe ontwikkelt zich, gegeven een bepaald domein in de gezondheidszorg, een beroepsgroep? Blijkbaar kan de maatschappelijk gevoelde noodzaak tot na- en later voorzorg zowel leiden tot het ontstaan van het psychiatrisch-sociaal werk als van de sociaalpsychiatrische verpleegkunde. Ter oriëntatie wordt er eerst een schets gegeven van de ontwikkeling van de psychiatrische verpleegkunde in het algemeen, dat wil zeggen van het ontstaan ervan in de psychiatrische inrichtingen.

In hoofdstuk 4 wordt de informatie uit de hoofdstukken 2 en 3 nader geanalyseerd. De ontwikkelingen in de Verenigde Staten, Duitsland en Nederland worden samengevat weergegeven en met elkaar vergeleken. Die vergelijking blijkt bruikbaar te zijn om de eerste onderzoeksvraag, te weten hoe in de gezondheidszorg een apart domein sociale psychiatrie tot stand is gekomen, te beantwoorden. De vergelijking blijkt ook bruikbaar om de tweede onderzoeksvraag, namelijk hoe zich in het domein van de sociale psychiatrie een afzonderlijke verpleegkundige beroepsgroep heeft ontwikkeld, in aanzet te beantwoorden. Dat zal gebeuren in termen van het in hoofdstuk 1 gegeven theoretische kader, meer in het bijzonder de van Benson afgeleide ideeën over inter- en intraprofessionele coherentie. In hoofdstuk 4 wordt verder aangegeven hoe in de hoofdstukken daarna vorm zal worden gegeven aan het meer in detail beantwoorden van de tweede onderzoeksvraag.

Hoofdstuk 5 geeft, eveneens op basis van literatuurstudie, inzicht in de ontwikkelingen in Nederland vanaf de Tweede Wereldoorlog tot rond 1985. Tegen die tijd is de uitbouw van de extramurale geestelijke gezondheidszorg in een stelsel van Regionale Instellingen voor Ambulante Geestelijke Gezondheidszorg, de RIAGG's, met inbegrip van de financiering daarvan uit de Algemene Wet Bijzondere Ziektekosten (AWBZ), voltooid. Het domein van de sociale psychiatrie is dan verzelfstandigd. In dat domein nemen de sociaalpsychiatrisch verpleegkundigen een sterke positie in. Aantallen verpleegkundigen zijn toegenomen, de opleidingseisen zijn hoog en de werkzaamheden hebben een professioneel karakter gekregen.

Het domein is niet alleen verzelfstandigd, maar ook in complexiteit toegenomen. Er is een verschuiving opgetreden van zorg voor ex-inrichtingspatiënten naar 
behandeling van cliënten met minder ernstige psychopathologie, die niet eerder met een inrichting in aanraking zijn gekomen. Er zijn meer beroepsbeoefenaren werkzaam dan alleen maar (sociaal-)psychiaters en (sociaal-)psychiatrisch verpleegkundigen. Ook nu wordt eerst voor het goede begrip een achtergrondschets gegeven. In dit geval gaat het om de ontwikkelingen in de psychiatrie in het algemeen, die met name in de jaren zeventig ingrijpend blijken te zijn.

De hoofdstukken 6 en 7 bestaan uit een onderbouwing en verbijzondering van de beschrijving van de Nederlandse situatie, zoals uiteengezet in hoofdstuk 5 . In hoofdstuk 6 wordt geschetst hoe de sociale psychiatrie zich heeft ontwikkeld in de provincie Limburg en hoe de sociaalpsychiatrisch verpleegkundigen daarin een plaats hebben gekregen en welke die plaats is. Dat gebeurt op basis van informatie uit jaarverslagen en archiefstukken van de voormalige Rooms Katholieke Vereniging Het Limburgse Groene Kruis en van de voormalige Venrayse psychiatrische inrichtingen Sint Servatius en Sint Anna. Uit de archieven van de beide inrichtingen is een steekproef getrokken van 382 statussen van patiënten die in de periode 1938-1973 met ontslag zijn gegaan. Uit deze statussen is afgeleid hoeveel en welke typen contacten er zijn onderhouden met welke personen en instanties buiten de inrichting. Vooruitlopend op de resultaten kan worden gemeld dat er zich rond 1960 een fundamentele omslag voordoet. Tot die tijd is er sprake van weinig systematische contacten tussen de inrichtingen en met name de familie van patiënten. Daarna is er in 80 tot 100 procent van de gevallen sprake van contacten tussen de inrichtingen en de sociaalpsychiatrische hulpverlening. Aanwijzingen voor contacten met familie van de patiënten nemen tegelijkertijd fors af. In hoofdstuk 6 zal deze ontwikkeling in detail worden weergegeven. Hoofdstuk 7 berust op in het kader van deze studie gevoerde gesprekken met gepensioneerde sociaalpsychiatrisch verpleegkundigen, aangevuld met informatie uit studies die eerder zijn verschenen. De nadruk ligt op de vragen hoe de verpleegkundigen de beroepsontwikkeling hebben beleefd en hoe ze de relatie met andere beroepsgroepen binnen het domein van de sociale psychiatrie kenmerken. Van belang is hier met name de vraag welke concrete activiteiten en vaardigheden bijdragen aan de professionalisering van de sociaalpsychiatrisch verpleegkundigen binnen de verpleegkundige professie en binnen het domein van de sociale psychiatrie. De gegevens in dit hoofdstuk beslaan de periode van de eerste helft van de jaren vijftig tot halverwege de jaren tachtig van de twintigste eeuw. De groep verpleegkundigen van wie informatie is verkregen, kan worden onderverdeeld in drie subgroepen. De eerste is de groep die vanaf eind jaren veertig, begin jaren vijftig, actief is geweest. Geen van hen heeft de opleiding MGZ/GGZ gevolgd, een deel heeft de overgang naar de Riagg meegemaakt. De tweede groep wordt beroepsmatig actief rond 1960. Ook van deze groep heeft niemand opleiding MGZ/GGZ gevolgd. Wel hebben alle verpleegkundigen uit deze categorie de RIAGGvorming meegemaakt. De derde groep bestaat uit vertegenwoordigers van de generatie die rond 1950 is geboren. Ze hebben met elkaar gemeen dat ze allemaal de 
opleiding EMGZ/GGZ hebben gevolgd, de eerste in 1974, de laatste in 1980. Sommigen hebben de overgang naar de RIAGG's nog meegemaakt, anderen zijn na de RIAGG-vorming beroepsmatig actief geworden. Die RIAGG-vorming is, zoals zal blijken, in alle opzichten een markeringspunt in de ontwikkeling van de sociaalpsychiatrische verpleegkunde.

In hoofdstuk 8 worden de ontwikkelingen in het domein van de geestelijke gezondheidszorg en de sociaalpsychiatrische verpleegkunde vanaf 1985 tot ongeveer 2005, met een enkele uitloper naar de jaren erna tot 2008, globaal weergegeven. De onderscheiden domeinen van de intra- en de extramurale geestelijke gezondheidszorg vermaatschappelijken en de grenzen ertussen worden minder duidelijk. De rol die de overheid speelt is daarbij een zeer bepalende. Aan het begin van de eenentwintigste eeuw kondigt zij beleidsvoornemens aan die, indien uitgevoerd, verregaande gevolgen zullen hebben voor de sectorale structuur van de tweedelijns geestelijke gezondheidszorg. In dit hoofdstuk wordt eveneens duidelijk dat de ontwikkelingen in de sociaalpsychiatrisch verpleegkundige beroepsgroep sterk worden bepaald door ontwikkelingen en gebeurtenissen van buitenaf. De wijziging in het opleidingsstelsel, met onder meer als gevolg het opheffen van de opleiding MGZ/GGZ, is daarvan een voorbeeld. Nieuw is dat de verpleegkundigen, althans een spraakmakende groep, duidelijk stelling nemen in het domeindebat en kiezen voor het werken met moeilijk benaderbare en behandelbare patiënten en voor wat wordt genoemd "het sociaalpsychiatrische gedachtegoed".

Het laatste hoofdstuk bevat een reflectie op de bevindingen van deze studie en, mede op basis van recente en te verwachten ontwikkelingen, een blik vooruit op de toekomst van de sociaalpsychiatrische verpleegkunde.

\subsection{Een visie op domeinen, beroepen en professionalisering}

Beroepsbeoefenaren in de gezondheidszorg hebben als aandachtsgebied, als domein, gezondheidsproblemen. Ze zijn in staat zich op die problemen te richten omdat ze over bepaalde kennis en vaardigheden beschikken waarover anderen niet of in onvoldoende mate beschikken.

De gezondheidsproblemen variëren in complexiteit. Problemen met een lage mate van complexiteit, zoals hulp in de huishouding, kunnen worden aangepakt door het werk op te delen in relatief simpele taken die kunnen worden uitgevoerd door vaak laag opgeleide werkers. Er is dan sprake van arbeidsdeling zonder specialisatie en de organisatie daarvan kan worden samengevat onder de noemer bureaucratisering. Meer ingewikkelde problemen, zoals de extramurale begeleiding van psychiatrische patiënten, lenen zich er niet goed toe om te worden opgelost door middel van een dergelijke taakverdeling. Er is behoefte aan kennis, oordeelsvorming en vaardigheden van beroepsbeoefenaren, verkregen tijdens veelal langdurige 
scholing en door stage en werkervaring. Bij zulke vormen van werkorganisatie kan worden gesproken van professionalisering en professies.

In de loop van de tijd is het verschijnsel professionalisering op verschillende manieren bestudeerd.

In de functionele benadering wordt de vraag gesteld naar het waarom van het ontstaan van professies. Centraal staat de opvatting dat professies hun gezag ontlenen aan hun maatschappelijke functies. Die functies verwerven ze doordat er sprake is van modernisering of toenemende maatschappelijke complexiteit en dus ook van toenemende complexiteit van problemen. Voor de oplossing hiervan is gespecialiseerde kennis nodig en het zijn professionals die daarover beschikken. Er zijn met andere woorden specialisten nodig die het tot hun werk maken om omschreven problemen op te lossen. "Id "Ideology of service" ofwel goed-doen is de kern van professioneel handelen, waarbinnen eigenbelang geen rol speelt. De relatie artspatiënt is er een voorbeeld van. ${ }^{12}$ De arts is de deskundige die affectief neutraal, functioneel specifiek en universeel zijn kennis aanwendt om mensen te helpen. De patiënt is de niet-deskundige die op de arts vertrouwt. ${ }^{13}$

In de kenmerkenbenadering staat niet de vraag centraal hoe professies ontstaan, maar hoe ze kunnen worden gekenmerkt, hoe ze van niet-professies kunnen worden onderscheiden. Tot de kenmerken van professies worden gerekend: het beschikken over wetenschappelijk gefundeerde kennis; het verrichten van activiteiten die het algemeen belang dienen en die door niemand anders mogen of kunnen worden uitgevoerd; het hebben van autonomie over de beroepsuitoefening. Aan het proces van professionalisering kunnen de volgende stadia worden onderscheiden; het streven naar wettelijk erkenning; het inrichten van eigen (universitaire) opleiding en examens; het opstellen van een ethische code en het streven naar internationalisering. ${ }^{14}$ Deze stadia, over de volgorde waarvan in de literatuur geen overeenstemming bestaat, suggereren een begin- en een eindpunt in het ontwikkelingsproces van beroep naar professie. ${ }^{15}$

De machtsbenadering of "strategy of occupational control" concentreert zich op het streven naar macht en de manier waarop een professie die verkrijgt en gebruikt. De medische professie is door Freidson hét voorbeeld genoemd van een beroepsgroep die daarin is geslaagd. Zij heeft veel routinewerk afgestoten, bijvoorbeeld naar verpleegkundigen, wettelijke steun gekregen voor haar machtspositie ten aan-

\footnotetext{
${ }^{11}$ Houten, van D. (2006). Professionalisering en arbeidsdeling. Sociale Interventie, 2, 17-25, 18.

12 Ibidem, 18.

${ }^{13}$ Stevens, F., \& Philipsen, H. (2003). Professionalisering van beroepen in de gezondheidszorg. In C.W. Aakster, \& J.W. Groothoff (eds.), Medische sociologie: sociologische perspectieven op ziekte en zorg. $5^{\mathrm{e}}$ geh. herz. dr. Groningen/Houten: Wolters Noordhoff , 86.

${ }^{14}$ Ibidem, 87.

${ }^{15}$ Boom, van der H. (2008). Home nursing in Europe: patterns of professionalisation and institutionalisation of home care and family care to elderly people in Denmark, France, the Netherlands and Germany. Amsterdam: Aksant, 43.
} 
zien van definiëring en aanpak van problemen, een markt gecreëerd voor haar diensten en het monopolie verkregen over haar opleidingen. ${ }^{16}$ Illich ziet de macht van de medische professie onder meer zichtbaar worden in afhankelijkheid van de patiënten die door experts worden gered. ${ }^{17}$

Deze benaderingen bieden aanknopingspunten voor vruchtbare bestudering van van professies.

Abbott's commentaar op deze professionaliseringsopvattingen is dat de assumpties die eraan ten grondslag liggen, voor kritiek vatbaar zijn. Die assumpties zijn: professies ontwikkelen zich volgens een gegeven patroon; de ontwikkeling van een professie voltrekt zich onafhankelijk van die van andere gerelateerde professies; structuur en culturele claims van professies zijn belangrijker dan het concrete werk; professies zijn homogene, intern weinig gedifferentieerde eenheden en, tot slot, het proces van professionalisering verandert niet in de loop van de tijd. ${ }^{18} \mathrm{Er}$ wordt, volgens Abbott, te veel nadruk gelegd op "empirical facts and structural characteristics (in Abbott's terms: 'external appearances') while the processes and interactions preceding these outcomes (Abbott: 'intrinsic qualities of professions') are far more important to professions". ${ }^{19}$ Om die "processes and interactions" goed in beeld te krijgen, pleit hij ervoor om de inhoud van het werk, die zichtbaar wordt in diagnostiek, besluitvorming en interventie, als uitgangspunt van onderzoek naar professies te nemen. ${ }^{20}$

Professies worden door Abbott zeer ruim omschreven als "exclusive occupational groups applying somewhat abstract knowledge to particular cases". ${ }^{21}$ "Although its precise meaning is not narrowed down, people generally understand what is meant by the term profession, and therefore need no further specification of what a profession 'is' or represents. Instead, it is more useful to focus on their roles and functions in society". ${ }^{22}$

Professies claimen zeggenschap of jurisdictie over de manier waarop ze werken, over de manier waarop ze hun problemen en taken definiëren. De mate van succes van het werk, van de interventies, bepaalt in hoge mate de kracht van die claim en daarmee de mate van succesvol professionaliseren, eventueel van het voortbestaan van een beroepsgroep. Onderbouwing met behulp van een (abstract) kennissysteem is daarbij van belang. Een (abstract) kennissysteem is in staat vragen en taken

\footnotetext{
${ }^{16}$ Stevens F. \& Philipsen, H. Professionalisering van beroepen in de gezondheidszorg, 89.

${ }^{17}$ Illich, I.D., Zola, I.K. \& MacNight, J. (1977). Disabling professions. London: Boyars, 29.

${ }^{18}$ Abbott, A. (1988). The system of professions: an essay on the division of expert labor.Chicago: The University of Chicago Press, 17.

${ }^{19}$ Boom, van der, H. Home nursing in Europe: patterns of professionalisation and institutionalisation of home care and family care to elderly people in Denmark, France, the Netherlands and Germany, 47.

${ }^{20}$ Abbott, A. The system of professions: an essay on the division of expert labor, 40.

${ }^{21}$ Ibidem, 318.

${ }^{22}$ Boom, van der, H. Home nursing in Europe: patterns of professionalisation and institutionalisation of home care and family care to elderly people in Denmark, France, the Netherlands and Germany, 46.
} 
te bepalen, te herdefiniëren en te beschermen tegen eventuele overnames door anderen.

In de werkelijkheid van de complexe hedendaagse gezondheidszorg zijn de professionele claims echter niet absoluut en worden ze niet enkel bepaald door de beroepsgroep in kwestie. Er zijn niet veel complexe problemen die het domein zijn van één professie. ${ }^{23}$ Bij het oplossen van de overlast die bijvoorbeeld iemand die psychotisch is in de buurt veroorzaakt, zijn zowel de probleemdefinitie van de wijkagent als die van de sociaalpsychiatrisch verpleegkundige relevant. Samenwerking en afstemming zijn onontkoombaar, en daarmee zijn de grenzen tussen beroepsgroepen doorlaatbaar. De analyse van de ontwikkeling van aan elkaar gerelateerde beroepen is dan ook onvolledig als niet de bestudering van dat grensgebied en de zich daarop afspelende interprofessionele competitie wordt meegenomen.

Naast het feit dat professies elkaar onderling beïnvloeden, maken ze ook deel uit van een maatschappelijk krachtenveld. ${ }^{24}$ Ook binnen dat veld streven ze naar erkenning van hun professionele praktijk en van de wetenschappelijke onderbouwing daarvan. Ontwikkelingen in dat veld hebben invloed op de aard en de inhoud van de activiteiten van professies. Gedacht kan worden aan wet- en regelgeving en ontwikkelingen bij de afnemers, zoals het ontstaan van cliëntenbelangenverenigingen.

Er kunnen, samenvattend, drie perspectieven worden onderscheiden die leiden tot een vruchtbare studie van professies, in dit geval van de sociaalpsychiatrische verpleegkunde: het intraprofessionele, het interprofessionele en het metaprofessionele perspectief.

Een nadere concretisering van de bestudering van professies kan gebeuren aan de hand van de ideeën van Benson. ${ }^{25}$ Ofschoon die ideeën betrekking hebben op de interactie tussen organisaties, bieden zij aanknopingspunten voor het bestuderen van professies.

Bij het analyseren van de betrekkingen tussen professies kunnen de dimensies domeinconsensus, ideologische consensus, positieve evaluatie en werkcoördinatie worden onderscheiden. Domeinconsensus is de mate waarin er tussen aan elkaar gerelateerde professies overeenstemming bestaat over elkaars taken, rollen en werkterrein. Ideologische consensus is de mate waarin professies het met elkaar eens zijn over de aard van elkaars werkzaamheden, over de visie die aan het werk ten grondslag ligt. Onder positieve evaluatie wordt verstaan de mate waarin er positief wordt geoordeeld over elkaars werk. De mate waarin er onderlinge afstemming

\footnotetext{
${ }^{23}$ Boom, H. van der, Philipsen, H., \& Stevens, F. Een schets van de professionalisering van de wijkverpleging in Nederland in de laatste vijftig jaar (1950-2004), 116.

${ }^{24}$ Abbott, A. The system of professions: an essay on the division of expert labor, 33.

${ }^{25}$ Benson, J.K. (1975). The interorganizational network as a political economy. Administrative Science Quarterly, 20, 229-249, 235-236.
} 
bestaat van de wederzijdse activiteiten wordt geplaatst onder de noemer werkcoordinatie.

Een voorbeeld ter verduidelijking. Verzorgenden en verpleegkundigen zijn betrokken bij de zorg voor patiënten die als gevolg van functie-uitval na een ongeluk zichzelf niet meer kunnen verzorgen. De verzorgenden zijn vooral gericht op het verzorgen in striktere zin, op goede lichaamshygiëne. De verpleegkundigen zijn erop gericht dat de patiënt zo snel en zo goed mogelijk weer voor zichzelf kan zorgen. $\mathrm{Er}$ bestaat in dit voorbeeld consensus over het domein, te weten de zorg voor iemand met functiebeperkingen. Er bestaat geen consensus over de visie van waaruit de werkzaamheden worden verricht, dus geen ideologische consensus. Bij de ene groep gaat het immers om verzorgen, bij de andere om revalidatie of herstel. Het is voorstelbaar dat beide groepen niet onder de indruk zijn van elkaars concrete werkzaamheden. In het verlengde daarvan is het eveneens niet ondenkbaar dat ze die werkzaamheden niet goed op elkaar afstemmen. Met andere woorden: de evaluatie van elkaars werkzaamheden is laag en de werkcoördinatie laat te wensen over.

Het ontwikkelen van mono- en interdisciplinaire richtlijnen kan, ofschoon met name bedoeld als mogelijkheid tot kwaliteitsbeheersing, worden bezien vanuit het oogpunt van intra- en interdisciplinaire coherentie. Met het opstellen en het accepteren van de richtlijnen, bijvoorbeeld de multidisciplinaire richtlijn depressie bij volwassenen, geven beroepsgroepen te kennen dat ze omschreven gezondheidsproblemen op een omschreven wijze benaderen en welke rol ze daarin hebben. Dat de overheid richtlijnontwikkeling stimuleert kan worden gezien als een aspect van metaprofessionele invloed op beroepsgroepen in een domein, in dit geval het domein van de geestelijke gezondheidszorg.

De vier dimensies domeinconsensus, ideologische consensus, positieve evaluatie en werkcoördinatie vertonen, zoals het voorbeeld laat zien, een zekere mate van samenhang. Met samenhang wordt bedoeld dat verandering op de ene dimensie zal leiden tot verandering op de andere dimensies, dat er sprake is van balans in de betrekkingen tussen professies. Balans moet niet worden opgevat in de mechanistische betekenis, waarin een verandering op de ene dimensie automatisch zal leiden tot aanpassing op een andere dimensie. Bedoeld wordt dat er een tendens bestaat tot covariatie op de vier dimensies. ${ }^{26}$ Als twee professies geen consensus hebben over elkaars domein, dan zal er ook niet of nauwelijks sprake zijn van werkcoördinatie. Uitgezet op een continuüm van hoog naar laag, zullen de vier dimensies dicht bij elkaar in de buurt komen. Naarmate er op de dimensies hoger of lager wordt gescoord op dat continuüm, kan er worden gesproken van hogere of lagere interprofessionele coherentie.

Eenzelfde redenering als hiervoor kan ook worden gebruikt voor het vaststellen van de intraprofessionele coherentie. Naarmate er sprake is van meer overeen-

\footnotetext{
${ }^{26}$ Hermans, E. (2000). In het verkeerde bed: het zorgtraject van een cohort CVA-patiënten na ziekenhuisopname. Proefschrift Maastricht. Maastricht: Universiteit Maastricht, 117.
} 
stemming binnen een professie over de vier dimensies domeinconsnsus, ideologische consensus, positieve evaluatie en werkcoördinatie is die coherentie hoger. Daarmee wordt geacht te zijn voldaan aan een belangrijke voorwaarde voor succesvol professionaliseren.

De mate van balans op de vier dimensies is niet enkel de aangelegenheid van de betrokken professies, maar is mede afhankelijk van maatschappelijke krachten. De al eerder genoemde wet- en regelgeving maar ook zich wijzigende opvattingen onder zorggebruikers over goed hulpverlenerschap zijn hiervan voorbeelden. Variatie in het evenwicht is enkel mogelijk binnen de grenzen die factoren uit het maatschappelijke krachtenveld eraan stellen.

Zowel uitgaande van de opvattingen van Abbott als van Benson's ideeën kunnen een intra-, een inter- en een metaprofessioneel perspectief nuttig zijn bij het nader bestuderen van professies. 


\section{Hoofdstuk 2}

\section{Het ontstaan van de beweging van de sociale psychiatrie: een overzicht tot aan de Tweede Wereldoorlog}

\section{$2.1 \quad$ Inleiding}

Rond de overgang van de achttiende naar de negentiende eeuw groeit onder medici die zich bezighouden met psychiatrische patiënten de opvatting dat het runnen van psychiatrische inrichtingen een specialisme is dat specifieke kennis en vaardigheden vereist. In die inrichtingen, zo wordt geclaimd, kunnen mensen door psychiaters worden genezen van hun psychische klachten. ${ }^{27}$ Ofschoon deze claim weinig succesvol is, groeit het aantal opnames vanaf omstreeks 1850 sterk. Tegelijkertijd neemt ook het aantal inrichtingen toe.

Aan het einde van de negentiende eeuw is het domein van de psychiatrie in de westerse wereld praktisch beperkt tot de inrichtingen. Daarin zijn twee beroepsgroepen verantwoordelijk voor de patiëntenzorg: medici, al dan niet psychiatrisch geschoold, en verzorgend en bewakend personeel dat niet is opgeleid om zijn taken uit te voeren. De oorzaken van psychiatrische problemen worden gezocht in afwijkingen aan het zenuwstelsel, meer precies aan afwijkingen in de hersenen. Effectieve interventies zijn er nauwelijks. Onrust, agressie, drang en dwang komen veelvuldig voor en de situatie in de inrichtingen is, zowel voor patiënten als voor verzorgend personeel, slecht. De grote aantallen opnames vormen een groeiende financiële belasting.

Aan het begin van de twintigste eeuw voltrekt zich een belangrijke verandering. Bij psychiaters ontstaat de idee dat patiënten, indien daartoe de omstandigheden worden gecreëerd, buiten de inrichting kunnen verblijven. Die idee kan worden verklaard vanuit het inzicht dat omgevingsfactoren een rol spelen bij het tot stand komen van psychische problemen en, bijgevolg, moeten worden betrokken bij het oplossen daarvan. Ofschoon er al eerder gedachten zijn ontwikkeld en initiatieven zijn genomen in die richting, beginnen die nu meer contouren te krijgen. Een andere verklaring wordt gevormd door de al genoemde onhoudbare omstandigheden in de inrichtingen en de toename van de kosten. Een laatste verklaring is de als gevolg

\footnotetext{
${ }^{27}$ De term "Psychiaterie" wordt in 1808 voor het eerst gebruikt door de Duitse arts Reil. In 1816 wordt het woord door hem ingekort tot "Psychiatrie". Shorter, E. (1997). A history of psychiatry: from the era of the asylum to the age of Prozac. New York: John Wiley, 17.
} 
van industrialisatie, urbanisatie en migratie ontstane maatschappelijke onrust. Die leidt tot bezorgdheid en als gevolg daarvan tot maatregelen ter bescherming van individu en samenleving.

Zo ontwikkelt zich langzamerhand een praktijk van begeleiding na ontslag van psychiatrische patiënten, nazorg genoemd. Doel daarvan is het bekorten van de opnameduur en het voorkomen van heropnames. Preventie van eerste opnames wordt al gauw toegevoegd aan de doelstelling. Daarmee wordt de aanzet gegeven tot het ontstaan van een nieuw domein in de gezondheidszorg: de sociale psychiatrie. Het is, zoals nog zal blijken, vooralsnog een domein van beperkte omvang.

Het bestuderen van de beginperiode van dat nieuwe domein is niet goed mogelijk zonder de inrichtingspsychiatrie erbij te betrekken. Ter inleiding wordt een korte schets gegeven van de inrichtingspsychiatrie van omstreeks 1850 tot aan de jaren twintig van de twintigste eeuw. Ook de aanzetten tot zorgverlening buiten de inrichting worden kort beschreven. Daarna komt het ontstaan van de sociale psychiatrie in Duitsland, de Verenigde Staten en Nederland tot aan de Tweede Wereldoorlog aan de orde. De twee eerste landen worden in de beschrijving meegenomen omdat de ontwikkelingen in Nederland er niet los van kunnen worden gezien.

\subsection{Inrichtingspsychiatrie}

\subsubsection{De situatie in de inrichtingen}

Het verschijnsel psychiatrische inrichting is betrekkelijk jong. Ofschoon er al sinds de Middeleeuwen kleine inrichtingen bestaan en het afzonderen van mensen in de tweede helft van de zeventiende eeuw gaat toenemen, begint wat wel het "grote opsluiten" wordt genoemd, rond de tweede helft van de negentiende eeuw. Het aantal opgenomen patiënten stijgt in Nederland tussen 1849 en 1928 van 39 tot 264 per 100.000 inwoners. Ook in andere Europese landen, zoals Duitsland, Frankrijk en Groot-Brittannië en in de Verenigde Staten voltrekt zich deze ontwikkeling. ${ }^{28}$

De inrichtingspsychiatrie van begin negentiende eeuw kenmerkt zich door ruwe, soms avontuurlijke behandeling, kwellerij en gebrekkige huisvesting. Concreet gaat het om bijvoorbeeld het "bain de surprise" of verrassingsbad, onderdompelingen "so lange als die Hersage des Psalms Miserere dauert" 29 of stortbaden "in einer Anstalt viele Wochen hintereinander täglich 200 bis 300 Eimer kalten Wassers gewaltsam auf den Kopf eines Kranken". ${ }^{30}$ Een rapport van de Inspecteurs der Gestich-

\footnotetext{
${ }^{28}$ Peeters, H.F.M. (1982). Historische fasen in aard en behandeling van geestesziekten. In J.W.M. Binneveld, C. Brinkgreve, A.J. Lameijn, H.F.M. Peeters, P. Vandermeersch, C.P. de Vos, \& J. Vijselaar, Een psychiatrisch verleden: uit de geschiedenis van de psychiatrie. Baarn: Ambo Boeken, 21.

${ }^{29}$ Kraepelin, E. (1918). Hundert Jahre Psychiatrie. Zeitschrift für die Gesamte Neurologie und Psychiatrie, $38,161-275,201$. Een voorbeeld van het verrassingsbad is de val van de patiënt in de vijver, door het openen van een valluik als hij over het bruggetje loopt.

${ }^{30}$ Ibidem, 203.
} 
ten voor Krankzinnigen van 5 oktober 1842 bericht over het Zinnelooshuis te Maastricht. "De ligging voor de armen bestaat uit strozakken, enkelen op los stroo, hetwelk slechts tweemaal per jaar ververscht wordt; de anderen hebben bedden: in eene zaal met 6 kribben sliepen 12, in een andere met 4 kribben 8 krankzinnigen, dus twee bij elkaar in één bed". ${ }^{31}$

De in de eerste helft van de negentiende eeuw opkomende "moral treatment" heeft betrekkelijk weinig gevolgen voor de situatie in de inrichtingen. De beweging is gebaseerd op de opvatting dat psychiatrische patiënten zieke mensen zijn, in principe behandelbaar, en geen beesten of criminelen die vastgebonden of gestraft moeten worden. In zijn meest pure vorm bestaat de "moral treatment" uit een regiem van werken en zelfdiscipline, waardoor een routinematige en gestructureerde omgeving wordt gecreëerd. ${ }^{32}$ De rol van de medicus is erg gewichtig. Volgens Heinroth treedt de psychiater anno 1818 op als helper en redder, als vader en weldoener, als betrokken vriend en vriendelijke opvoeder maar ook als "prüfender, richtender, strafender Gerechtigkeitspfleger und gleichsam als sichtbarer Gott der Kranken. Er wirke wie einem Monarchen vergleichbar". ${ }^{33}$

Het in de praktijk toepassen van de ideeën van de "moral treatment" is niet wijd verbreid geweest. In de Verenigde Staten worden de principes ervan slechts in enkele inrichtingen toegepast en de voordelen komen maar weinig patiënten ten goede. "Moral treatment was, moreover, the original spur to the development of widespread institutionalization of the insane and for nearly a century it remained the model of asylum management" ${ }^{34}$ Op het Europese vasteland is het niet veel anders. In Nederland is, behalve in de in 1849 geopende inrichting Meerenberg te Bloemendaal, van "moral treatment" niet veel te merken. ${ }^{35}$

Als de psychiatrie zich in de tweede helft van de negentiende eeuw, in navolging van de somatische geneeskunde, natuurwetenschappelijk gaat oriënteren, verandert de situatie nauwelijks. De Duitse universitaire psychiatrie wordt toonaangevend. Er wordt veel nagedacht en gefilosofeerd over en onderzoek gedaan naar organische oorzaken van psychische problemen, maar dat levert geen effectieve behandeling op. "University psychiatry's primary goal was the scientific understanding of disorders through systematic observation, experimentation and dissection". ${ }^{36}$

\footnotetext{
${ }^{31}$ Scheer, W. van der (1933). Nieuwe inzichten in de behandeling van geesteszieken. Groningen: J.B. Wolters, 16.

${ }^{32}$ Caplan, R.B. (1969). Psychiatry and the community in nineteenth-century America: the recurring concern with the environment in the prevention and treatment of mental illness. New York: Basic Books, 5.

${ }^{33}$ Kraepelin, E. Hundert Jahre Psychiatrie, 236.

${ }^{34}$ Caplan, R.B. Psychiatry and the community in nineteenth-century America: the recurring concern with the environment in the prevention and treatment of mentall illness, 4.

${ }^{35}$ Vijselaar, J. (1980). De zedenkundige behandeling en de afschaffing van de lijfsdwang in het gesticht Meerenberg. In J.M.W. Binneveld et al., Een psychiatrisch verleden: uit de geschiedenis van de psychiatrie, 147.

${ }^{36}$ Porter, R. (2002). Madness: a brief history. New York: Oxford University Press, 145.
} 
Ideeën over erfelijkheid en over constitutionele en organische degeneratie komen in de belangstelling te staan.

Uit onderzoek van zeventig statussen van vier Nederlandse inrichtingen tussen 1885 en 1920 blijkt onder meer het volgende: binnen twee jaar wordt vierendertig procent van de patiënten genezen ontslagen; negentien procent wordt niet genezen ontslagen, hetgeen in veel gevallen opname elders betekent; zevenenveertig procent sterft binnen twee jaar. ${ }^{37}$

Anno 1917 wordt "de dokter aangetroffen op het laboratorium, terwijl de hoofdverpleegster lijsten invult, de verpleegsters schrobben en de verpleegden, aan zichzelf overgelaten, in den tuin rondwaren". ${ }^{38}$ Uit de periode 1916-1919 zijn de herinneringen van de psychiater Van der Scheer, inspecteur van het krankzinnigenwezen. "In onooglijke kleren loopen ze daar, met vieze pakjes aan, doelloos rond, in een kleurloozen zaal met de door koffie verkleurde crême witte muren, met dikke vastgezette tafels en banken". ${ }^{39}$ Querido schrijft over zijn jaren in de inrichtingspsychiatrie tussen 1927 en 1931: "De taak van de arts in de inrichting was teruggebracht tot die van bewaker, een custos van een postzegelverzameling. De objecten moesten netjes gecatalogiseerd zijn en niet beschadigd worden...". ${ }^{40}$

Bij psychiaters in Nederland en landen zoals Duitsland, Engeland en de Verenigde Staten heerst aan het begin van de twintigste eeuw wat wordt genoemd therapeutisch nihilisme. ${ }^{41}$ De toestand in de inrichtingen is er vrijwel gelijk: groot, overvol, met slechte omstandigheden voor de patiënten en verzorgenden. De groep bewoners bestaat uit een mengeling van psychiatrische patiënten, verstandelijk gehandicapten, onmaatschappelijken en dementen. Grote aantallen patiënten met dementia paralytica, het laatste stadium van de geslachtsziekte syfilis, vergen veel en intensieve verzorging. Het nauwelijks geschoolde personeel kan die verzorging, evenals de zorg aan zwakke ouderen en lichamelijk zieken, niet bieden. De hygiëne laat zwaar te wensen over. De in 1917 door Wagner von Jauregg ontwikkelde malariakuur tegen syfilis vormt een uitzondering op de algehele malaise. Die therapie, die, mits tijdig toegepast, een doorbraak kan worden genoemd, versterkt de opvatting dat ook aan andere ziektes somatische oorzaken ten grondslag liggen en dat de interventies dienovereenkomstig moeten zijn. ${ }^{42}$ Dat levert weinig op.

\footnotetext{
${ }^{37}$ Boschma, G. (1999). High ideals versus harsh reality: a historical analysis of mental health nursing in Dutch asylums, 1890-1920. Nursing History Review, 7, 127-151, 137.

38 Meinema, Th. (1922). Over gezinsverpleging van geesteszieken. Amsterdam: Antonia Wilhelmina Fonds, 33.

${ }^{39}$ Scheer, W. van der. Nieuwere inzichten in de behandeling van geesteszieken, 1.

40 Querido, A. (1980). Doorgaand verkeer: autobiografische fragmenten. Lochem-Poperinge: De Tijdstroom, 86.

${ }^{41}$ Carpenter, M. (1980). Asylum nursing before 1914: a chapter in the history of labour. In C. Davies (ed.). Rewriting nursing history. London: Croom Helm/Totowa: Barnes \& Noble, 128. Querido, A. Doorgaand verkeer: autobiografische fragmenten, 85 . Shorter, E. A history of psychiatry: from the era of the asylum to the age of Prozac, 191.

${ }^{42}$ Shorter. E. A history of psychiatry: from the era of the asylum to the age of Prozac, 194.
} 


\subsubsection{Arbeid in de inrichtingen}

Arbeid is al vroeg een belangrijk onderdeel van het leven van alledag in de inrichtingen. Degenen die dat kunnen, dat wil zeggen de rustige en chronische patiënten, worden geacht bij te dragen in de kosten die met de opname samenhangen.

In Prestwich Asylum in Engeland werken in 1857159 van de 248 mannelijke patiënten onder meer op de boerderij, in de bakkerij en aan het onderhoud van gebouwen en installaties. Van de 260 vrouwen zijn er 193 actief in de wasserij, de linnenkamer en bij schoonmaakwerk. ${ }^{43}$ In de Verenigde Staten werken patiënten in de keuken, de timmerwerkplaats, de kleermakerij, de schoenmakerij, de machinekamer en op de boerderij. ${ }^{44}$

Het Koninklijk Besluit van 23 april 1846, waarbij toestemming wordt verleend tot het oprichten van een geneeskundig gesticht voor krankzinnigen in Maastricht, vermeldt als voorwaarde dat de tuin wordt gebruikt als werkplek voor patiënten. ${ }^{45}$ Ook Duitsland heeft een lange traditie van arbeid in de inrichtingen. ${ }^{46}$

De naam van de Duitse psychiater Simon is vanaf de jaren twintig van de twintigste eeuw nauw verbonden met arbeid in de inrichting onder de naam "aktivere Krankenbehandlung", in het Nederlands vertaald met actieve of actievere therapie. Onder het motto "Die Wurzel des Übels liegt in der Untätigkeit" ontwikkelt Simon een uitgekiend systeem van bezigheden. Het is de bedoeling om de patiënten op te voeden tot redelijke en verantwoordelijke mensen en om rust en orde aan te kweken. ${ }^{47}$ De in zwang zijnde bad- en bedverpleging isoleert de patiënten, volgens Simon, van de werkelijkheid, met negativisme als resultaat. Een gevolg daarvan is het optreden van "Narrenfreiheit". De nieuwe behandeling bestaat dan ook uit bezigheden met als doel alles wat naar ziekte neigt "mit zielbewußter Konsequenz und Energie entgegen zu wirken, andererseits alles, was der Kranke an Betätigungsdrang aufbringt... nach einer normalen, gesunden Richtung hinzudrängen..." ${ }^{48}$ Het bijvoeglijk naamwoord actievere slaat niet enkel op de patiënten, maar ook op de hulpverleners. Zij moeten alles in het werk stellen om bij te dragen aan de genezing van de patiënten, en waar genezing niet mogelijk is aan een rustig en gestructureerd leven. Dat stelt hoge eisen aan zowel psychiaters als verpleegkundigen. ${ }^{49}$

De actievere therapie, later ook wel arbeidstherapie genoemd, wordt in Nederland ingevoerd en gepropageerd door Van der Scheer. Ze zal nog tot ver in de twin-

\footnotetext{
${ }^{43}$ Carpenter, M. Asylum nursing before 1914: a chapter in the history of Labour, 130.

${ }^{44}$ May, M.E. (1893; herdrukt 1949). Nursing the insane. In I.A. Hampton (ed.). Nursing of the sick. New York: McGraw-Hill, 178.

${ }^{45}$ Cornips, J. (1952). Bijdrage tot de geschiedenis van de krankzinnigenzorg te Maastricht. Maastricht: Burgerlijk Armbestuur i.s.m. Sociaal Historisch Centrum voor Limburg, 49.

${ }^{46}$ Simon, H. (1929). Aktivere Krankenpflege in der Irrenanstalt. Berlin: Walter Gruyters, 9.

${ }^{47}$ Ibidem, 7.

Narrenfreiheit is het recht van de nar om zijn meester de waarheid, hoe onaangenaam ook, te zeggen. In de psychiatrie stond het woord voor het gebruiken van de ziekte als excuus voor gek gedrag.

${ }^{48}$ Ibidem, 18.

${ }^{49}$ Ibidem, 162-166.
} 
tigste eeuw hét middel blijven om patiënten bezig te houden en hen structuur te bieden. Het zijn overigens niet enkel behandelinhoudelijke, maar ook financiële motieven die de opmars van deze therapievorm succesvol maken. De patiënten dragen door hun werk op onder andere boerderij en mattenvlechterij, in wasserij en linnenkamer, bij in de opnamekosten. ${ }^{50}$

De behandelmogelijkheden in de psychiatrische inrichtingen blijven tot de jaren vijftig van de twintigste eeuw nagenoeg ongewijzigd onsuccesvol. Ook de opkomst van de psychoanalyse, die in Nederland in de jaren dertig doorzet, biedt de inrichtingspsychiatrie weinig nieuwe mogelijkheden. "Af en toe werden er wel pogingen gedaan om patiënten een analytische behandeling te geven, maar dat werden zelden successen...". ${ }^{51}$

\subsection{Zorg voor psychiatrische patiënten buiten de inrichtingen}

Vrijwel tegelijk met de opkomst van de inrichtingen worden er, zij het sporadisch, buiten die inrichtingen activiteiten ontplooid voor patiënten die zijn ontslagen. $\mathrm{Er}$ ontstaan initiatieven die onder de naam nazorg kunnen worden samengevat. "Before our present day type of social work was organized, psychiatry here and there had probably for a century done a kind of social work under the name of after care. In Switzerland, France and many other regions there where organized provisions to pave way for patients discharged from hospitals for the insane" ${ }^{\prime 2}$

Duitsland kent al in 1829 een vorm van nazorg, Engeland vanaf omstreeks 1870. In de Verenigde Staten is er vanaf het einde van de negentiende eeuw toenemende aandacht voor ontslagen patiënten en hun familie, onder meer door het maatschappelijk werk. ${ }^{53}$

In 1860 verschijnt in Nederland een verhandeling van de Leidse commissaris van politie, getiteld: "Beschouwingen over het plan tot oprichting van een Nederlandsch Genootschap tot ondersteuning van behoeftige krankzinnigen en van herstelden, die uit een gesticht zijn ontslagen, doch onverzorgd zijn". Rond dezelfde tijd ontstaan patronaten met als doel "toezicht op behoeftigen, die krankzinnig zijn geweest, ten einde... de oorzaken welke hen opnieuw krankzinnig konden maken, van hen verwijderd te houden, hen met raad en daad bij te staan, hunnen zedelijke ver-

\footnotetext{
${ }^{50}$ Later wordt er veel inpakwerk gedaan en onder andere kerstboomverlichting vervaardigd. Eind jaren zestig van de twintigste euw wordt in de inrichting Sint Servatius te Venray een schoenfabriek opgezet. Billekens, A.J. et al. (2005). 100 Jaar psychiatrie in Venray: geschiedenis van de psychiatrische instellingen St. Anna en St. Servatius. Zutphen: Walburg Pers, 146.

${ }^{51}$ Brinkgreve, C. (1982). De zorg voor zenuwlijders in Nederland rond de eeuwwisseling en de opkomst van de psychoanalyse. In J.M.W. Binneveld et al., Een psychiatrisch verleden: uit de geschiedenis van de psychiatrie, 198.

${ }_{52}$ Meyer, A. (1922). Historical sketch and outlook of psychiatric and social work. Hospital Social Service, 5, 221-225, 221.

${ }^{53}$ Deutsch, A. (1940). The convergence of social work and psychiatry: a historical note. Mental Hygiene, 24, 92-97, 94
} 
betering te bevorderen, hen godsdienstig onderwijs en geneeskundige raad te verschaffen" ${ }^{54}$

Per brief van 30 januari 1860 vraagt de minister van Binnenlandse Zaken aan de Nederlandse krankzinnigengestichten om de oprichting van patronaten voor behoeftige krankzinnigen te overwegen. Het Burgerlijk Armbestuur te Maastricht, dat het gesticht Calvariënberg beheert, antwoordt dat een patronaat daar niet nodig is omdat er speciale maatregelen zijn genomen. Er bestaat al een afdeling "Gebrekkigenzorg" van waaruit patiënten aangepaste arbeid verrichten en werk buiten de instelling kunnen zoeken. ${ }^{55}$ Veel leveren de patronaten niet op. De middelen zijn ontoereikend en autoriteiten en psychiaters zijn niet erg geïnteresseerd. ${ }^{56}$

Een ander voorbeeld van zorgverlening buiten de inrichting is de gezinsverpleging. In het Belgische Geel worden al sinds de dertiende eeuw patiënten in gezinnen geplaatst. ${ }^{57}$ In Schotland is het opnemen van patiënten in gezinnen, verspreid over het land, sinds eeuwen in gebruik. In 1858 wordt deze vorm van hulpverlening wettelijk geregeld omdat een in 1855 uitgebracht rapport van een Royal Commission laat zien "that there was an ample field and urgent need for improving the condition of the insane poor under private care" ${ }^{58}$

In Nederland wordt de eerste patiënt in 1894, vanuit de inrichting Veldwijk te Ermelo, in een gezin geplaatst. ${ }^{59}$ Zo'n gezin houdt aan de plaatsing van een vrouwelijke patiënt een kleine vergoeding en gratis hulp in de huishouding over. Kleine zelfstandigen, zoals boeren, die patiënten opnemen, hebben goedkope arbeidskrachten. Het zijn enkel de rustige patiënten die voor plaatsing in aanmerking komen.

Een hoge vlucht heeft de gezinsverpleging in en buiten Nederland nooit genomen. Uit verslagen van de inspecteurs van het Staatstoezicht op Krankzinnigen over de periode 1909-1911 blijkt dat er nog geen 150 patiënten in gezinsverpleging zijn. In 1936 gaat het om 1020 en in het topjaar 1939 om ongeveer 1100 personen, iets meer dan vier procent van het aantal inrichtingspatiënten. Daarna daalt het aantal en beweegt het zich rond de 700 in de periode 1950-1966. ${ }^{60}$ In Duitsland is in 1925 anderhalf procent van de psychiatrische patiënten in gezinsverpleging. ${ }^{61}$ De nazorg en de gezinsverpleging, zoals hiervoor omschreven, kunnen ontslag-faciliterend of opnamevervangend worden genoemd. Ze zijn weinig behandel-inhoudelijk en weinig actief van aard.

\footnotetext{
${ }^{54}$ Meijers, F.S. (1939). De voor- en nazorg van geestelijk hulpbehoevenden. Amsterdam: Centrale Vereeniging ter Behartiging van de Belangen van Zenuw- en Zielszieken, 15.

${ }^{55}$ Cornips, J. Bijdrage tot de geschiedenis van de krankzinnigenzorg te Maastricht, 56.

${ }^{56}$ Schepper, R. de (1991). De Pameijer Stichting (1926-1991): een geschiedenis van de sociale psychiatrie en verstandelijk-gehandicaptenzorg te Rotterdam. Rotterdam: Pameijer Stichting, 26.

${ }^{57}$ Meinema, Th. (1922). Over gezinsverpleging van geesteszieken, 9.

${ }^{58}$ Ibidem, 31.

${ }^{59}$ Ibidem, 55.

${ }^{60}$ Esch, P. van der (1975-1980). Geschiedenis van het Staatstoezicht op Krankzinnigen, deel III. Leidschendam: Ministerie van Volksgezondheid en Milieuhygiëne, 96.

${ }^{61}$ Haselbeck, H. (1985). Zur Sozialgeschichte der "Offenen Irren-Fürsorge": vom Stadtasyl zum sozialpsychiatrischen Dienst. Psychiatrische Praxis, 12, 171-179, 174. Absolute aantallen zijn niet vermeld.
} 
Al rond 1850 wordt er door enkele psychiaters de aandacht gevestigd op beperkende aspecten van de inrichtingspsychiatrie en op het belang van omgevingsfactoren voor de behandeling. Leubuscher, enige arts in een Duitse kliniek met jaarlijks 7.000 opnames, zegt in 1848: "Die Psychiater sollen aus den abgelegenen Anstalten ausziehen und sich den Problemen des Lebens Stellen" en zijn vakgenoot Brosius in 1860: "Es müssen die häuslichen Verhältnisse der sozialen Irren anders und so werden, daß diese in ihnen bleiben können". ${ }^{62}$

De Duitse psychiater Griesinger pleit in dezelfde tijd voor de bouw van zogenaamde "Stadtasyle", inrichtingen die niet meer dan een half uur van de stad zijn verwijderd. Vóór elke opname dient een inrichtingsarts de patiënt te bezoeken om zich een beeld te kunnen vormen van de omstandigheden. De opnameduur dient te worden beperkt tot een jaar zodat de familie niet vervreemdt van de patiënt. Ontslag op proef en ambulante nabehandeling moeten mogelijk worden gemaakt. ${ }^{63}$ Ofschoon Griesinger ervan uitgaat dat veel patiënten niet zullen genezen, is verblijf in een inrichting voor een groot aantal echter niet nodig, en onder bepaalde voorwaarden kunnen ze zonder die inrichting, zo meent hij. Hij krijgt echter geen gehoor. Tijdens een bijeenkomst van psychiaters in 1864 wordt het inrichten van "Stadtasyle" afgewezen. Als argumenten worden aangevoerd: enkel de grote inrichting kan voorzien in de variatie van ziektebeelden, nodig voor de opleiding van psychiaters; alleen de grote inrichting voorziet in voldoende toezicht en bewaking; de grote inrichting is goedkoper dan de kleine. ${ }^{64}$

De Zwitserse psychiater Bleuler beschrijft in 1905 dat vroegtijdig ontslag van mensen met schizofrenie goed mogelijk is en dat er voor een lang verblijf in de inrichting geen therapeutische argumenten zijn. ${ }^{65}$

Ook buiten Europa leven opvattingen over de ongewenst grote afstand tussen inrichtingen en de maatschappij. In de Verenigde Staten zegt de voorzitter van de Association of Medical Superintendants in 1896: "This separation from the ordinary, everyday life of our fellow man is an evil. It was far better for us to enter more into the life of the community in which we live ...". ${ }^{66}$

$\mathrm{Er}$ is dus al vanaf het ontstaan van de grote inrichtingen sprake van een bepaalde mate van extramurale oriëntatie. Die krijgt gestalte in de vorm van nazorg/armenzorg na ontslag uit de inrichting, opnamevervangende gezinsverpleging en, zij het bij een beperkt aantal psychiaters, in het besef dat die inrichtingen niet zaligmakend en soms niet nodig zijn en dat het betrekken van de sociale omgeving van patiënten bij

\footnotetext{
${ }^{62}$ Ibidem, 172.

${ }^{63}$ Ibidem, 172.

${ }^{64}$ Ibidem, 172.

${ }^{65}$ Rähmi, L. (1918/1919). Die Dauer der Anstaltsbehandlung der Schizophrenen, Teil 1. PsychiatrischNeurologische Wochenschrift, 45/46, 284-291, 284.

${ }^{66}$ Caplan, R.B. Psychiatry and the community in nineteenth-century America: the recurrent concern with the environment in the prevention and treatment of mental illness, 303.
} 
de behandeling wenselijk is. Veel verder dan het ventileren van hun ideeën komen de psychiaters aanvankelijk echter niet. Daarin komt verandering aan het begin van de twintigste eeuw.

\section{$2.4 \quad$ Nazorgdiensten}

De Duitse psychiater Kolb begint in 1908 in Kutzenberg en in 1911 in Erlangen vanuit de inrichting een nazorgdienst. ${ }^{67}$ In aanmerking komende patiënten worden na ontslag begeleid door de arts, zodat zij hun plaats in gezins- en arbeidsleven weer kunnen innemen. Hoewel het accent ligt op nazorg, is het voorkomen van opneming ook punt van aandacht. ${ }^{68}$ Tijdens de Eerste Wereldoorlog plaatst Kolb patiënten in gezinnen omdat de inrichtingen gebrek hebben aan voedsel, brandstof en personeel. "Na den oorlog echter heeft hij met kracht den opbouw van zijn zoogenaamde 'offene Fürsorge' of 'externe Dienst', zoals hij het noemde, ter hand genomen, waarbij de economische omstandigheden het slagen in hooge mate in de hand hebben gewerkt". 69

Bij het uitbreken van de Eerste Wereldoorlog bestaan er in verschillende Duitse steden "Fürsorgestellen". Deze houden zich bezig met "Arbeit, Beratung der hilfesuchenden Kranken und Angehörigen, Beschaffung von Schlafstellen und Arbeitsgelegenheit, Verteilung von Unterstützungen". ${ }^{70}$ Ze worden, zoals in Frankfurt, onderhouden door de gemeenten. Het doel ervan is het opsporen van mensen met afwijkend gedrag en het voorkomen van opnames. ${ }^{71}$

Op het platteland worden de diensten onderhouden door psychiatrische inrichtingen. Er worden vanuit de gemeentelijke diensten door maatschappelijk werkenden en vanuit de inrichtingen door verpleegkundigen, huisbezoeken afgelegd om problemen te bespreken, de voortgang te bewaken en patiënten te stimuleren de psychiater te bezoeken. $^{72}$

\footnotetext{
${ }^{67}$ Haselbeck, H. Zur Sozialgeschichte der "Offenen Irren-Fürsorge": vom Stadtasyl zum sozialpsychiatrischen Dienst, 174. De ideeën voor zo'n dienst heeft Kolb al in 1902 op papier gezet.

In 1920 wordt oonder leiding van de psychiater Wendenburg in Rheinland-Westfalen psychiatrische zorg onderdeel van de maatschappelijke gezondheidszorg. Dit "Gelsenkirchener Modell" is in 1927 in 33 steden en 10 regio's ingevoerd. Huisbezoeken en preventieve tewerkstelling zijn er onderdeel van.

${ }^{68}$ Pameijer, J. (1928). De buitendienst van "Maasoord". Conferentie gehouden door den Raad van Bestuur van het Antonia Wilhelminafonds, 11-20, 15.

${ }^{69}$ Ibidem, 13.

${ }^{70}$ Raecke (1921). Moderne Irrenfürsorge und soziale Psychiatrie. Westdeutsche Ärzte-Zeitung, 12, 48, 48.

${ }^{71}$ Alem, V. van, Fransman, J., Heijden, H. van der, Jonkers, F., Limbeek, J. van, \& Wouters, L. (1991). Querido's legacy: social psyciatry in Amsterdam from 1932 to 1991. Amsterdam: Municipal Health Service, 1112. De leider van de dienst in Frankfurt, Raecke, claimt dat in tien procent van de gevallen opname in een inrichting wordt voorkomen.

${ }^{72}$ Faltlhauser, V. (1927). Die speziellen Gesichtspunkte für die Organisation der offenen Geisteskrankenfürsorge: Fürsorgepfleger. In H. Roemer, G. Kolb, \& V. Faltlhauser, Die offene Fürsorge in der Psychiatrie und ihren Grenzgebieten: ein Ratgeber für Ärzte, Sozialhygieniker, Nationalökonomen, Verwaltungsbeamte sowie Organe der öffentlichen und privaten Fürsorge. Berlin: Julius Springer, 212, 216.
} 
$\mathrm{Na}$ een onderbreking gedurende de oorlog nemen deze zorgpunten de draad weer op. "Nachgehende Fürsorge", nazorg, wordt een begrip in Duitsland. In 1930 kent ongeveer vijfenzeventig procent van de psychiatrische inrichtingen een of andere vorm van deze zorgverlening. ${ }^{73}$

Het is de nazorg in Duitsland die sterk model staat voor de extramurale zorg aan ontslagen inrichtingspatiënten die vanaf halverwege de jaren twintig in Nederland wordt ingevoerd. Die nazorg wordt aanvankelijk wat aarzelend, vanaf de zestiger jaren consequent sociale psychiatrie genoemd. Het begrip sociale psychiatrie is echter al langer bekend en wordt in de tijd op verschillende manieren gedefinieerd en gebruikt.

\subsection{Sociale psychiatrie}

\subsubsection{Duitsland}

De term sociale psychiatrie wordt, voor zover bekend, voor het eerst door de Duitse psychiater Ilberg in 1904 gebruikt en als volgt omschreven: "Die Lehre von den für die geistige Gesundheit der Gesamtheit verderblichen Umständen und den zu deren Abwehr nützlichen Maßregeln wollen wir soziale Psychiatrie nennen". ${ }^{74}$ Volgens deze definitie is het doel van de sociale psychiatrie de bescherming van de geestelijke volksgezondheid. De term wordt dan in de Duitstalige literatuur een aantal jaren niet meer gevonden.

In 1912 heeft de psychiater Fischer het over "die Psychiatrie außerhalb der Anstalten, oder wie wir sie ihrem Hauptcharakter nach auch nennen können, die soziale Psychiatrie" ${ }^{75}$ In 1919 verbreedt hij de omschrijving, betrekt er de preventie van maatschappelijke misstanden bij en zegt dat sociale psychiatrie een onderdeel is van de psychiatrie. ${ }^{76}$ Ook het voorkomen van voortplanting bij "schwer degenerierte Menschen" wordt als taak van de sociale psychiatrie gezien. ${ }^{77}$

Roemer, psychiater, geeft een aantal argumenten voor de "sociale opdrachten" van de psychiatrie. Het eerste is dat er bezuinigd moet worden; Duitsland zit na de Eerste Wereldoorlog diep in de financiële problemen. Het tweede argument is dat tijdens de oorlog de ervaring is opgedaan dat veel mensen, die wegens gebrek aan

\footnotetext{
${ }^{73}$ Haselbeck, H. Zur Sozialgeschichte der "Offenen Irren-Fürsorge": vom Stadtasyl zum sozialspsychiatrischen Dienst, 175.

Het Duitse woord "Fürsorge" wordt vaak foutief vertaald met voorzorg. "Fürsorge" betekent zorg, ook sociale zorg/maatschappelijk werk. Een "Fürsorgerin" is een maatschappelijk werkster. "Nachgehende Fürsorge" betekent nazorg.

${ }^{74}$ Ilberg, G. (1904). Soziale Pychiatrie. Monatschrift für Soziale Medizin, 1, 321-329, 393-398, 321.

${ }^{75}$ Fischer, M. (1912). Neue Aufgaben der Psychiatrie in Baden. Allgemeine Zeitschrift für Psychiatrie und Psychisch-gerichtliche Medizin, 69, 34-68, 63.

${ }^{76}$ Fischer, M. (1919). Die soziale Psychiatrie im Rahmen der sozialen Hygiene und allgemeinen Wohlfahrtspflege. Allgemeine Zeitschrift für Psychiatrie und Psychisch-gerichtliche Medizin, 76, 529-548, 529.

77 Kolb, G. (1920). Inwieweit sind Änderungen im Betriebe der Anstalten geboten? PsychiatrischNeurologische Wochenschrift, 21/22, 163-176, 164.
} 
voorzieningen noodgedwongen zijn ontslagen, niet langdurig in een inrichting hoeven te worden opgenomen. Ook meent Roemer dat er aandacht moet worden besteed aan het toegenomen maatschappelijke verval in de vorm van criminaliteit, het zich snel uitbreidende aantal gevallen van syfilis en de sterk gestegen middelenafhankelijkheid. $\mathrm{Er}$ is in een tijd van vervlakking behoefte aan een herwaardering van de "denkende beroepen" en daaraan kan de psychiater met zijn kennis van psychologie en psychopathologie een bijdrage leveren. ${ }^{78}$

Van de discussie over sociale psychiatrie in Duitsland is de eugenetica vrijwel vanaf het begin, en later ook de rassenleer, onderdeel. De al genoemde Ilberg schrijft in 1904 dat de sociale psychiatrie de opgave heeft om duidelijk te maken dat het trouwen met een geestes- of zenuwzieke of met iemand die komt uit een belaste familie, schadelijk is voor het nageslacht. ${ }^{79}$ De rapportage in de statussen van de nazorgdiensten over patiënten en hun milieus leveren waardevolle informatie op "für Heriditäts- und Rassenforschung". ${ }^{80}$ Dat dat type onderzoek daadwerkelijk wordt uitgevoerd, blijkt uit een retrospectieve studie, die teruggaat tot 1712, waarin "die Beziehungen von Umwelt und Vererbung in der Struktur der Psychopathien" wordt onderzocht in "die Familie 135". 81

Het begrip sociale psychiatrie wordt in 1932 voor lange tijd voor het laatst in de Duitse literatuur gevonden. ${ }^{82}$ Met de opkomst van het nationaal-socialisme begin jaren dertig komt de psychiatrie helemaal in het teken van de rassenleer te staan. Tussen 1939 en 1945 werken artsen en verpleegkundigen mee aan het doden van, naar recente schattingen, 260.000 psychiatrische patiënten en verstandelijk gehandicapten. "Some of the psychiatrists who participated... had been advocates of mental health care reforms in pre-national socialistic times"..$^{83}$ De uitgebreide administratie van de nazorgdiensten blijkt cynisch genoeg een nuttig hulpmiddel te zijn bij het opsporen van patiënten.

De Duitse psychiatrie, lange tijd internationaal toonaangevend, raakt gaandeweg geïsoleerd van ontwikkelingen elders. Tot ver na de Tweede Wereldoorlog is ze niet in staat zich los te maken van het verleden en wordt ze in haar ontwikkeling

\footnotetext{
78 Roemer, H. (1920/1921). Die sozialen Aufgaben des Irrenarztes in der Gegenwart. PsychiatrischNeurologische Wochenschrift, 45/46, 342-351, 344.

${ }^{79}$ Ilberg, G. Soziale Psychiatrie, 21-22.

${ }^{80}$ Raecke. Moderne Irrenfürsorge und Psychiatrie, 48.

${ }^{81}$ Schweighofer, (1926). Die Familie 135: eine sozialpsychiatrische Untersuchung. Zeitschrift für die Gesamte Neurologie und Psychiatrie, 623-654, 623.

Ook in Nederland en de Verenigde Staten is de eugenetica thema van aandacht. In de Verenigde Staten geeft in 1913 de Mental Health Exhibit inzicht in de erfelijke bepaaldheid van zwakzinnigheid en de snelle voortplanting van zwakzinnigen. Zie Goei, L. de. (2001). De psychohygiënisten: psychiatrie, cultuurkritiek en de beweging voor geestelijke volksgezondheid in Nederland, 1924-1970. Nijmegen: SUN, 47-48, 72.

${ }^{82}$ Hoffmann-Richter, U., \& Finzen, A. (1995). Sozialpsychiatrie-Spezialdisziplin oder Sichtweise?: Entwicklungsgeschichte des Begriffs und seiner Bedeutung. In A. Finzen, \& U. Hoffmann-Richter (Hrsg.), Was ist Sozialpsychiatrie?: eine Chronik. Bonn: Psychiatrie Verlag, 11-19, 13.

${ }^{83}$ Schmiedebach, H., \& Priebe, S. (2004). Social psychiatry in Germany in the twentieth century: ideas and models. Medical History, 48, 449-472, 463.
} 
geremd. ${ }^{84}$ De "Psychiatrie-Enquête" in 1975 geeft de finale aanzet tot schaalverkleining en extramuralisering. ${ }^{85}$

\subsubsection{De Verenigde Staten}

Adolf Meyer, psychiater van Zwitserse afkomst, heeft aan het begin van de twintigste eeuw veel invloed op het denken over en de ontwikkeling van de psychiatrie in de Verenigde Staten. Hij benadrukt, zonder biologische oorzaken te ontkennen, dat de sociale context en de ervaringen van de patiënt onderdeel zijn van de etiologie en aanknopingspunten bieden voor de behandeling. "There are in the life records of our patients certain ever returning tendencies and situations which a psychiatrist of exclusive brain speculation, autointoxications, local injections and internal secretions could never have discovered" ${ }^{87}$

Nazorg is volgens Meyer een veelbelovende ontwikkeling in de psychiatrie. Tijdens een lezing in 1909 zegt hij: "It is bound to lead to an organization which will be able to meet the highest achievement of farsighted social economy prophylaxis". 88 Met zo'n programma bedoelt hij de verregaande samenwerking tussen inrichtingen, overheden, huisartsen, bezorgde burgers en allerlei instanties in overzichtelijke verzorgingsgebieden, districts genoemd, met " $a$ district health officer and a district school committee and a district recreation committee, a district tax committee, a district charity or civic work committee- a tangible expression of what the district stands for". 89

Meyer mag dan in zijn reorganisatie-ideeën ver gaan, hij is ook zo pragmatisch om te zeggen: "See what works and what does not work; mobilize the patient's assets, and they may suffice to counterbalance his deficiencies".$^{90}$ In zijn denken is hij onder meer beïnvloed door James, Dewey en Mead en er zijn naast kenmerken van het pragmatisme ook kenmerken van het symbolisch interactionisme in terug te vinden. Hij is van mening dat het functioneren van de mens wordt beïnvloed door wat hij denkt en "his symbolizations are critical to his functioning as a social organism" ${ }^{\prime 1}{ }^{11}$ Zijn opvattingen zijn tot in de jaren twintig richtinggevend voor de ontwikkeling van de National Committee for Mental Hygiene, opgericht in 1909, en voor het denken van maatschappelijk werkenden en psychiatrisch-sociaal werkenden.

\footnotetext{
${ }^{84}$ Müller, M. (1982). Erinnerungen: erlebte Psychiatriegeschichte 1920-1960. Berlin: Springer, 383.

${ }^{85}$ Schmiedebach, H., \& Priebe, S. Social psychiatry in Germany in the twentieth century: ideas and models, 467.

${ }^{86} \mathrm{Lidz}, \mathrm{T}$. (1966). Adolf Meyer and the development of American psychiatry. American Journal of Psychiatry, 123, 320-332, 322.

${ }^{87}$ Caplan, R.B. Psychiatry and the community in nineteenth-century America: the recurring concern with the environment in the prevention and treatment of mental illness, 307.

${ }^{88}$ Lief, A. (1948). The commonsense psychiatry of Dr. Adolf Meyer. New York: McGraw-Hill, 302.

${ }^{89}$ Caplan, R.B. Psychiatry and the community in nineteenth-century America: the recurring concern with the environment in the prevention and treatment of mental illness, 308.

${ }^{90} \mathrm{Lidz}, \mathrm{T}$. Adolf Meyer and the development of American psychiatry, 327.

${ }^{91}$ Ibidem 326.
} 
Meyer voegt al vroeg de daad bij het woord. Zijn vrouw Mary Meyer begint in 1904 met het afleggen van huisbezoeken aan patiënten en verzamelt zo informatie over woon- en leefmilieu die haar man betrekt in de behandeling. Ze wordt wel de eerste psychiatrisch-sociaal werkster genoemd. ${ }^{92}$

De aandacht voor de relatie tusen ziekte en omgeving is echter niet beperkt tot de psychiatrie. In 1905 betrekt de arts Cabot in het Massachusetts General Hospital als eerste een maatschappelijk werker bij de zorg voor opgenomen patiënten. Cabot is van mening dat de puur biologisch georiënteerde benadering van ziekte is achterhaald en dat de scheiding tussen ziekenhuis en samenleving moet worden opgeheven. ${ }^{93}$ Zo vraagt hij om huishoudelijke hulp voor een hartpatiënte en wil hij informatie over een depressieve man. "This patient tells us stories of abuse at home by his sons... Can you tell us what the conditions are there?" 94

Het maatschappelijk werk doet dus al vroeg in de twintigste eeuw zijn intrede in de intramurale gezondheidszorg en begint daarmee zijn liefdadigheidskarakter te ontgroeien. Het in werking treden van de New York State Act in 1906 biedt ruimte voor het ontstaan van nazorgdiensten aan de state mental hospitals waaraan maatschappelijk werkenden worden verbonden. Er ontstaan ook afdelingen maatschappelijk werk voor klinische patiënten. ${ }^{95}$ Zo ontwikkelt zich langzaam een specialisme binnen het maatschappelijk werk, dat in de tweede helft van het tweede decennium de naam psychiatrisch-sociaal werk krijgt. In hoofdstuk 3 wordt daarop nader ingegaan.

De term sociale psychiatrie wordt in de Verenigde Staten voor het eerst als volgt gebruikt door Southard in 1917: "Social psychiatry (Developing from a conjugation of social and psychiatric concepts as social psychology has already developed from a conjugation of social and psychological concepts - employing modern methods of social service investigation and care and aiming to make characterological and ethological categories and the available facts of the psychology of the instincts, vocational psychology and the like)". ${ }^{96}$ Deze nog weinig heldere omschrijving krijgt een jaar later meer inhoud als Spaulding het heeft over een cursus sociale psychiatrie voor maatschappelijk werkenden. "The course... aimed to show the adjustment which is necessary if man's primitive instincts and desires are to find adequate and

\footnotetext{
92 Ibidem, 328.

${ }^{93}$ Dorgan, R.E. (1970/1971). From demonology to scientific humanitarianism: social casework specializes. International Journal of Social Psychiatry, 17, 20-39, 34.

${ }^{94}$ Lubove, R. (1983). The professional altruist: the emergence of social work as a career 1880-1930. New York: Atheneum, 28. Oorspronkelijk gepubliceerd in 1965 door Harvard University Press.

${ }^{95}$ Dorgan, R.E. From demonology to scientific humanitarianism: social case work specializes, 34.

${ }^{96}$ Southard, E.E. (1917). Alienists and psychiatrists. Mental Hygiene, 1, 567-571, 569.

Finzen wijst erop dat Southard zich een vijftal jaren eerder in Heidelberg, in de buurt van de al genoemde psychiater Fischer, heeft opgehouden, en suggereert daarmee dat Southart de term uit Duitsland heeft overgenomen. Zie Finzen, A.(1998), Das Pinelsche Pendel: die Dimension des Sozialen im Zeitalter der biologischen Psychiatrie. Bonn: Das Narrenschiff, 23-24.
} 
constructive outlet in the environment which modern civilization offers. The course endeavored to show to what degree abnormal and antisocial behavior results from the inability to make such adjustment" ${ }^{97}$ In deze omschrijving wordt een relatie gelegd tussen menselijk gedrag en omgeving, meer precies over problemen die ontstaan als menselijk gedrag niet is aangepast aan de omgeving. Op basis van de cursusinhoud kan worden geconcludeerd dat er geen verschil is tussen sociale en klinische psychiatrie. ${ }^{98}$ Er komen geen thema's aan de orde waarin aanzetten tot sociaalpsychiatrische benadering van gedrag of gedragsproblemen zichtbaar worden.

In "The Kingdom of Evils" van Southard en Jarett, dat in 1924 verschijnt, wordt zowel van psychiatrisch sociaal werk als van sociale psychiatrie een omschrijving gegeven." Social psychiatry is not used as an alternative for psychiatric social work. Psychiatric social work is the special form of social work in which psychiatric knowledge is particularly required. Social psychiatry is an art now in the course of development by which the psychiatrist deals with social problems. Social psychiatry is a branch of psychiatry and a special kind of medical art. That part of knowledge of psychiatry which has a bearing upon social problems is given the social workers in courses named social psychiatry ..."..$^{99}$ Dat de definities van deze twee disciplines in hetzelfde boek worden gegeven is geen toeval. Southard is psychiater, Jarett is een van de voortrekkers van het maatschappelijk werk. Beiden zijn ze betrokken bij de sinds 1918 bestaande opleiding tot sociaalpsychiatrisch werkende.

Vanaf eind jaren twintig tot 1939 verdwijnt het begrip sociale psychiatrie uit de psychiatrische literatuur. In de sociologische literatuur komt het begrip regelmatig voor, maar het wordt slechts zelden gedefinieerd. Een van de uitzonderingen erop vormt de omschrijving van Brown in 1934. "The field of social psychiatry embraces all abnormal forms of social adjustment, made by individuals and groups as well". ${ }^{100}$ Vanaf die tijd eigenen de sociologen zich de sociale psychiatrie toe. "Like social psychology, social psychiatry is a division of sociology". ${ }^{101}$

\subsubsection{Nederland}

In Nederland verschijnt in 1923 voor zover bekend de eerste publicatie over sociale psychiatrie onder die noemer, met als titel "De sociale zijde der psychiatrie" van de hand van Beijerman. Hij pleit daarin voor het organiseren van "een buitendienst aan gestichten ter bevordering van vroegtijdig ontslag... hij zal aan de gemeenschap een aanzienlijk bedrag aan verpleegkosten besparen, hij zal de psychiatrie het nodige

\footnotetext{
${ }^{97}$ Spaulding, E.R. (1918). The training school of psychiatric social work at Smith College, Part 3: The course in social psychiatry. Mental Hygiene, 2, 586-589, 586.

${ }^{98}$ Bell, N.W., \& Spiegel, J.P. (1966). Social psychiatry: vagaries of a term. Archives of Social Psychiatry, 14, 337-345, 338.

${ }^{99}$ Ibidem, 339.

${ }^{100}$ Ibidem, 340.

101 Ibidem, 340.
} 
verband met de samenleving geven" ${ }^{102}$ Beijerman benadrukt dat zijn betoog verband houdt met "de tegenwoordige economische crisis en het streven naar versobering, ook in de krankzinnigenverpleging". ${ }^{103}$ Met zijn ideeën leunt hij zwaar op publicaties van Roemer en Kolb uit Duitsland, hetgeen zowel uit de inhoud van zijn artikel als uit de referenties blijkt.

Eveneens in 1923 verschijnt Querido's “Zeeburgerdorp; een sociaal psychiatrische studie". In die publicatie wordt het begrip sociale psychiatrie niet omschreven. Querido concludeert dat niet erfelijkheid, maar sociale omstandigheden de problemen van de in de woonschool verblijvende mensen veroorzaken, en dat maatregelen dienovereenkomstig moeten zijn. ${ }^{104}$ Beijerman noemt in 1928 als taak van de "moderne 'sociale psychiatrie'... om nauwkeuriger dan vroeger uit te maken door deskundig onderzoek van arts en verpleegster, wie op deze gronden wel en niet voor verpleging in een psychiatrische inrichting in aanmerking komt, voorts om de maatschappij de organen en krachten te geven, die het werk van de inrichting in de maatschappij kunnen voortzetten". ${ }^{105}$

In "Over sociale psychiatrie" omschrijft Bouman het begrip niet, maar heeft hij het over "de maatschappelijke oorzaken, die op het ontstaan van geestesziekten van invloed waren...", waardoor de psychiater "... van verpleger dokter is geworden en zich thans tenslotte ook tot sociaal medicus begint te vormen" ${ }^{106}$

Van der Scheer rekent tot het gebied van de sociale psychiatrie "alle vraagstukken welke samenhangen met de geestelijke volksgezondheid en haar invloed op en beïnvloeding door de maatschappij. Zij streeft daarbij in de allereerste plaats naar het vinden van middelen om geestesstoornissen en geestesziekten te voorkomen. Prophylaxis dus, ook wel psychische hygiëne, 'mental hygiene' genoemd...". ${ }^{107}$ Vier jaar later zegt hij dat de sociale psychiatrie zich bezig houdt met "alle maatschappelijke vraagstukken welke betrekking hebben op de stoornissen der geestelijke gezondheid van individu en gemeenschap". Daaronder vallen wet- en regelgeving, de behandeling en verzorging van patiënten in en buiten de inrichtingen, de preventie van psychiatrische ziekten en van "wilszwakte en maatschappelijke ongeschiktheid...". De aandachtsterreinen van de sociale psychiatrie en de geestelijke volksgezondheid zijn volgens Van der Scheer niet scherp te scheiden. "Hunne terreinen vallen samen daar waar het ziekelijke afwijkingen betreft, doch grenzen aan elkaar

\footnotetext{
102 Beijerman, W. (1923). De sociale zijde der psychiatrie. Nederlands Tijdschrift voor Geneeskunde, 67, 74-78, 78.

${ }^{103}$ Ibidem, 74.

${ }^{104}$ Querido, A. (1933). Het Zeeburgerdorp: een sociaalpsychiatrische studie. Leiden; Amsterdam: Stenfort Kroese, 48-49.

${ }^{105}$ Bijerman, W. (1928). Verzorging van zenuw- en zielszieken in de maatschappij: handleiding in het bijzonder voor wijkverpleegkundigen. Groningen; Den Haag: Wolters, 137.

${ }^{106}$ Bouman, K.H. (1929). Over sociale psychiatrie. Psychiatrische en Neurologische Bladen, 31, 133-148, 133.

${ }^{107}$ Scheer, W. van der (1930). Een blik in het arbeidsveld van den psychiater: klinische en sociale psychiatrie. Groningen; Den Haag: J.B. Wolters, 11.
} 
zoodra het betreft de belangen van den gezonden mensch en de beïnvloeding van de gezonde maatschappij. Dan betreedt men het terrein van de geestelijke volksgezondheid". ${ }^{108}$

Al voor het verschijnen van de eerste Nederlandstalige publicaties begint Meijers in 1917 in Amsterdam het Consultatiebureau voor Zenuw- en Zielszieken. ${ }^{109}$ Dat komt voort uit de pogingen om controle te krijgen op het aantal inwoners van de stad, dat wordt opgenomen in een inrichting. Meijers is adviseur bij de GG \& GD. Zijn bureau richt zich op materiële steun en begeleiding, maar ook op een "sociaalpsychiatrische benadering, waarin de sociale inzichten werden gecombineerd met de klinischpsychiatrische deskundigheid". ${ }^{110}$ Er is een dagelijks spreekuur, er worden door Meijers en een verpleegkundige huisbezoeken afgelegd, patiënten en familieleden krijgen adviezen en er wordt voor behandeling verwezen naar vrijgevestigde psychiaters of de polikliniek van de universiteitskliniek. "Veel meer dan verwijzen of bemiddelen deed men dus gewoonlijk niet, maar dat dit weinige toch in een behoefte voorzag blijkt duidelijk uit het snel stijgende aantal nieuwe ingeschreven gevallen". 111

De door Meijers in 1924 opgerichte Centrale Vereeniging ter Behartiging van de Maatschappelijke Belangen van Zenuw- en Zielszieken stelt binnen enkele jaren zestien van zulke consultatiebureaus in. Dat aantal blijft tot aan het eind van de jaren dertig ongewijzigd. De vereniging verzorgt cursussen voor wijkverpleegkundigen, zodat die kunnen worden ingezet bij de nazorg en bij het vroegtijdig herkennen van psychiatrische problemen. Eerder al, in 1920, ontstaat, uitgaande van de inrichting Het Apeldoornse Bos, het Consultatiebureau voor Joodse Zenuw- en Zielszieken, gevestigd in Amsterdam, waar een psychiater één keer per week spreekuur houdt. Dit bureau kan het best worden getypeerd als een externe polikliniek.

In de inrichting Maasoord in Rotterdam zet Pameijer in 1926 een buitendienst op. De buitendienst van Kolb in Duitsland staat hiervoor model. Ontslagen patiënten worden in hun eigen omgeving bezocht en er wordt wekelijks spreekuur of consultatiebureau gehouden. In 1931 worden voor 1.478 patiënten 11.359 huisbezoeken afgelegd, waarvan 1.482 door de arts en 9.877 "door het overige personeel. De consultatiebureau's werden 2.393 maal bezocht voor 821 gevallen". ${ }^{112}$ De buitendienst

\footnotetext{
${ }^{108}$ Scheer, W. van der (1934). Vraagstukken der sociale psychiatrie en der geestelijke volksgezondheid. Tijdschrift voor Sociale Geneeskunde, januari/februari, 3-12, 35-39, 4.

${ }^{109}$ Eerder, in Brouns et al. 2003 en in Brouns et al. 2007, is vermeld dat Meijers zijn consultatiebureau in 1916 instelt. In dat jaar wordt hij psychiatrisch-neurologisch adviseur bij de GG\&GD van Amsterdam.

${ }^{110}$ Grinten, T.E.D. van der (1987). De vorming van de ambulante geestelijke gezondheidszorg: een historisch beleidsonderzoek. Baarn: Ambo, 43.

${ }^{111}$ Kwast, S. van der (1974). Vijftig plus: de geschiedenis van de Dr. F.S. Meijers-Vereniging. In S. van der Kwast (red.), Het einde van onbegonnen werk?: vijftig jaar sociaalpsychiatrisch reclasseringswerk van de Dr. F.S. Meijers-vereniging. Meppel: Boom, 15.

${ }^{112}$ Pameijer, J.H. (1932). Over voor- en nazorg voor geestesziekten. Inleiding voor het $37^{\text {ste }}$ Gezondheidscongres te Amsterdam, 201.
} 
heeft als resultaat dat ontslag uit de inrichting kan worden bespoedigd, dat heropnemingen worden voorkomen en dat kosten worden bespaard. ${ }^{113}$ Pameijer ziet het financiële belang goed in. "Zoodra er trouwens sprake is van voorkoming van opnamen, komen wij op een vraagstuk, waarvoor de bestuurders van Rijk, Provincie en Gemeente, afgezien van andere overwegingen, levendige belangstelling tonen. Zooals $u$ allen bekend is, worden jaarlijks steeds grotere bedragen geëischt voor de kosten van verpleging in inrichtingen en zal elk middel, dat het aantal verpleegden enigszins drukt, als een welkome verbetering worden beschouwd". ${ }^{114}$ Esser relativeert het belang van het consultatiebureau. "Wat zich op dat spreekuur meldde viel tegen. De volwassen patiënten waren bang weer opgenomen te zullen worden, en bleven weg. Wel zag hij (Pameyer) veel kinderen met leer- en opvoedingsmoeilijkheden". 115

Jelgersma opent in 1928 in Leiden een consultatiebureau voor geestelijke volksgezondheid, dat in 1929 wordt omgevormd tot een nazorgdienst aan de psychiatrische inrichting Endegeest. Hij ontwikkelt ook een vorm van acute psychiatrie, "d.w.z. systematische sociaalpsychiatrische interventies, gericht op het voorkomen van gestichtsopname ${ }^{\prime 1}{ }^{116}$ Andere inrichtingen volgen en organiseren een of andere vorm van nazorg. Begin 1940 bestaan er veertien buitendiensten en wordt er op 30 plaatsen spreekuur gehouden.

In 1931 wordt Querido bij de Amsterdamse GG \& GD aangesteld. Zijn aanstelling komt voort uit de financiële moeilijkheden als gevolg van de economische crisis. Zo'n 3.000 Amsterdammers zijn opgenomen in inrichtingen; de kosten daarvan komen ten laste van de gemeente. Querido bezoekt al deze patiënten en trekt als conclusie: “... er zit er geen een die niet gek is, die ten onrechte in een gesticht zit. Ze zitten er allemaal met een goeie psychiatrische reden. Maar tien procent kan eruit, als de sociale omstandigheden het toelaten" ${ }^{117}$ Querido wordt in 1934 hoofd van de afdeling voor Geestes- en Zenuwziekten. Al in 1927 heeft een Amsterdamse delegatie, de Commissie van Onderzoek inzake de Verpleging en Verzorging van Zenuwzieken, Krankzinnigen en Maatschappelijk Ongeschikten, een oriënterend bezoek gebracht aan de Fürsorgestelle in Frankfurt. ${ }^{118}$ Het door de commissie uitgebrachte rapport is mede de aanzet tot de benoeming van Querido. Er wordt in Amsterdam, met Frankfurt als voorbeeld, een vorm van voor- en nazorg opgezet, inhoudende onder andere hulp bij het vinden van huisvesting, het regelen van financiële ondersteuning, hulp bij het vinden van werk en het geven van voorlichting en van om-

\footnotetext{
${ }^{113}$ Schepper, R.M. de. De Pameijer Stichting (1926-1991): een geschiedenis van de sociale psychiatrie en verstandelijk gehandicaptenzorg te Rotterdam, 14.

${ }^{114}$ Pameijer, J. De buitendienst van "Maasoord", 12.

${ }^{115}$ Esser, P.H. (1970-1971). Sociale psychiatrie. Kampen: J.H. Kok, 12.

${ }^{116}$ Blok, G., \& Vijselaar, J. (1998). Terug naar Endegeest: patiënten en hun behandeling in het psychiatrisch ziekenhuis Endegeest 1897-1997. Nijmegen: SUN, 96.

${ }^{117}$ Heerma van Voss, A.J. (1991). Querido, een levensverhaal. Maandblad Geestelijke Volksgezondheid, 46, 722-811, 730.

${ }^{118}$ Alem, V. van et al. Querido's legacy: social psychiatry in Amsterdam from 1932 to 1991, 11-12.
} 
gangsadviezen aan mensen uit de omgeving van de patiënt. De zorg is zowel bedoeld om ontslag uit de inrichting te bevorderen als om heropnames en eerste opnames te voorkomen. Acute psychiatrie in geval van crisis wordt door Querido "psychiatrie d'urgence" genoemd.

Het succes van het werk wordt, net zoals in Rotterdam, met name gemeten aan de mogelijkheid om patiënten buiten de inrichting te houden. Dat blijkt, volgens Querido, te lukken. "Ik ben erin geslaagd om van '30 tot'39 het aantal geïnterneerden en geesteszieken constant te houden; dat groeide niet meer, dus op die manier kreeg ik prompt de wind mee". ${ }^{119}$ Tot 1950 is ongeveer 23 procent van de patiënten in Amsterdam jonger dan 20 jaar. ${ }^{120}$

Na Amsterdam volgen andere steden zoals Den Haag en Haarlem. Vrijwel tegelijkertijd ontstaan er ook provinciale initiatieven op het gebied van voor- en nazorg, al dan niet in samenwerking met kruisverenigingen. De provincies worden ingedeeld in districten, waarin artsen en verpleegkundigen, ook wel districtsverpleegkundigen genoemd, de zorg voor hun rekening nemen.

Eind jaren dertig bestaan er in vijf provincies voor- en nazorgdiensten, die in meerdere of mindere mate los van de inrichtingen functioneren. ${ }^{121}$ Met de buitendiensten van de inrichtingen geven de stedelijke en de provinciale nazorgdiensten vorm aan de extramurale zorg voor psychiatrische patiënten. De consultatiebureau's, uitgaande van Meijers' Centrale Vereniging, verliezen terrein en verdwijnen in de loop van de jaren veertig uit beeld.

De extramurale zorg kan met recht als nazorg worden gekarakteriseerd. Voorzorg in de zin van opnamepreventie is weliswaar aan de orde, maar komt pas zichtbaar tot ontwikkeling vanaf de jaren vijftig, zoals zal blijken in hoofdstuk 5 .

Hoe er door de diensten concreet wordt gewerkt, kan worden geillustreerd aan de hand van een casus uit 1931. "Het betrof een gezin waarvan de vrouw wegens krankzinnigheid in een gesticht verpleegd wordt... . De man zelf, die vroeger ook reeds korten tijd in een gesticht verpleegd was geworden was een paranoïde schizofreen met eigenaardige waanideeën... Het zag er vuil en verwaarloosd uit; de kleine kinderen vies, doch overigens gezond, het huisraad veelal stuk. Wij kwamen tot de opvatting, dat de verwaarlozing hier niet veroorzaakt werd door de ziekte van den man, doch doordat in dit gezin onvoldoende vrouwelijke hulp aanwezig was, terwijl bovendien de inkomsten van het gezin onvoldoende waren om het huis en den inventaris behoorlijk te onderhouden. Na moeizame pogingen is het ons gelukt voor dit gezin financiële steun te verkrijgen, het huis op te knappen, den inventaris

\footnotetext{
${ }^{119}$ Heerma van Voss, A. J. Querido, een levensverhaal., 746.

${ }^{120}$ Akkermans, C. (2006). Aanspoelen aan de Achtergracht: maatschappelijke ontwikkelingen, clientèlevorming en de psychiatrische patiënten van de Amsterdamse GG \& GD (1933-1988). Amsterdam: Aksant, 57.

${ }^{121}$ Grinten, T.E.D. van der. De vorming van de ambulante geestelijke gezondheidszorg: een historisch beleidsonderzoek, 56 .
} 
enigszins te vernieuwen, terwijl bovendien de buitenshuis werkende dochter nu 2 dagen per week thuis blijft om het huishouden behoorlijk te onderhouden. De zuster voor maatschappelijk werk houdt het gezin onder contrôle, en tot nu toe gaat alles naar wens. In dit geval was de schijn tegen den inderdaad psychotischen man, die zich tegenover ieder, die zich met zijn zaken wilde bemoeien afzijdig en dikwijls onaangenaam gedroeg. In werkelijkheid lag de directe oorzaak van den maatschappelijken toestand ergens anders en gelukte het door een deskundig en tactvol optreden een oplossing te verkrijgen, die uit maatschappelijk oogpunt meer bevrediging geeft en die bovendien het voordeel heeft, dat zij belangrijk goedkoper is dan die, die men zich aanvankelijk gedacht had". ${ }^{122}$

De aanvankelijk gedachte oplossing is opneming van de vader.

\subsection{Conclusies en discussie}

Begin twintigste eeuw speelt de psychiatrie in de Verenigde Staten, Duitsland en Nederland zich met name af in inrichingen. Het zijn grote, overvolle instellingen waarin een gemêleerde groep patiënten verblijft met een grote variatie aan gedragsuitingen en zorgbehoeften. De claim van de nog jonge psychiatrische beroepsgroep, die eruit bestaat dat de inrichtingen de geschikte omgeving vormen om patienten te genezen, wordt nauwelijks tot niet waargemaakt. Met het niet geschoolde verzorgende personeel richten de psychiaters zich met name op somatische zorg, het diagnosticeren van psychiatrische ziektes en het handhaven van rust en orde. De toestand in de inrichtingen is feitelijk onhoudbaar en door de groei van het aantal patiënten nemen de kosten sterk toe.

De als gevolg van industrialisatie, urbanisatie en migratie ontstane maatschappelijke onrust en ontwrichting leidt tot bezorgdheid en vraagt om ingrijpen ter bescherming van individuen en van de samenleving als geheel. Inzichten uit de psychologie en de sociologie bieden aanknopingspunten tot interveniëren en maken tegelijkertijd de urgentie daarvan duidelijk. Belangrijk is het inzicht dat menselijk gedrag niet enkel biologisch gedetermineerd is, maar dat omgevingsfactoren een rol spelen in het veroorzaken en in stand houden van gedragsproblemen én, omgekeerd, dat gedrag invloed heeft op de omgeving. Het voorkómen van gedragsproblemen en het betrekken van de omgeving bij de behandeling van al bestaande gedragsproblemen liggen daardoor als het ware voor de hand. Preventie van psychiatrische problemen wordt een nieuw aandachtspunt dat in de loop van de jaren het centrale thema van de psychohygiëne zal worden.

Het verplaatsen van de zorg van opgenomen psychiatrische patiënten van de inrichting naar de eigen leefomgeving opent nieuwe perspectieven voor wat tot dan de klinische psychiatrie is. De al eerder gesignaleerde onhoudbare omstandigheden

${ }^{122}$ Kwast, S. van der. Vijftig plus: de geschiedenis van de Dr. F.S. Meijers-Vereniging, 13-14. 
in de inrichtingen en de te verwachten financiële voordelen van extramurale behandeling vormen een bijkomende, maar niet onbelangrijke aanleiding om de aandacht te gaan richten op extramurale behandeling. Zo ontstaat in de Verenigde Staten en in Nederland op globaal gelijke wijze een nieuw domein, de sociale psychiatrie.

In de Verenigde Staten zijn psychiaters en maatschappelijk werkenden actief in dat domein, in Nederland zijn het psychiaters en verpleegkundigen. De werkzaamheden die worden verricht zijn nog weinig operationeel omschreven en de verschillende beroepsgroepen staan nog aan het begin van hun ontwikkeling. Hoe dat domein zich ontwikkelt en vooral waarom en hoe daarin maatschappelijk werkenden in de Verenigde Staten en verpleegkundigen in Nederland actief worden en professionaliseren, wordt in het volgende hoofdstuk uiteengezet. 


\section{Hoofdstuk 3}

\section{Het ontstaan van het psychiatrisch-sociaal werk in de Verenigde Staten en van de sociaalpsychiatrische verpleegkunde in Nederland}

\subsection{Inleiding}

In het vorige hoofdstuk is het ontstaan van de sociale psychiatrie aan het begin van de twintigste eeuw beschreven. Dat ontstaan kan worden bezien tegen de achtergrond van het inzicht dat de mens en zijn levensomstandigheden elkaar beïnvloeden. Het individu kan in de knel raken door maatschappelijke ontwikkelingen waar het weinig invloed op heeft. De samenleving op haar beurt kan negatief worden beïnvloed door "onaangepast" gedrag van bepaalde individuen en groepen. Levensomstandigheden en menselijk gedrag kunnen en moeten ten positieve worden beinvloed. Armoedebestrijding en preventie van psychiatrische problemen zijn daarvan voorbeelden.

Onder psychiaters, veelal werkzaam in een klinische omgeving, groeit de opvatting dat patiënten, indien de omstandigheden daartoe worden gecreëerd, buiten de inrichting kunnen leven. Dat idee wordt ook ingegeven door humanitaire en financiele overwegingen. De inrichtingen zijn weinig succesrijk en overvol. Verblijf van patiënten buiten de inrichtingen kan tot besparingen leiden. Er is inzicht nodig in de omstandigheden waarin de patiënten terecht komen en toezicht op de situatie als ze eenmaal extramuraal zijn. Het realiseren daarvan is slechts in beperkte mate een aangelegenheid van de psychiaters zelf. In Duitsland en Nederland gebeurt dat door verpleegkundigen, in de Verenigde Staten door maatschappelijk werkenden. Daarmee ontstaan een verpleegkundig specialisme, de sociaalpsychiatrische verpleegkunde, en een specialisatie van het maatschappelijk werk, te weten het psychiatrisch-sociaal werk.

Wat verwachten de psychiaters van de nieuwe beroepsbeoefenaren? Wat doen de laatsten concreet? Hoe zijn ze opgeleid? Hoe zijn de verhoudingen tussen psychiaters en de nieuwe werkers? Welke positie nemen de nieuwe beroepsgroepen in ten opzichte van enkele gerelateerde disciplines, te weten het maatschappelijk werk en de psychiatrische verpleegkunde? Hoe kunnen de beide groepen ten opzichte van elkaar worden omschreven? Hoe kan de divergentie in aanpak in Europa en de 
Verenigde Staten worden verklaard? Deze onderwerpen en de ontwikkelingen daarin tot aan de Tweede Wereldoorlog komen in dit hoofdstuk aan de orde.

Voor een goed begrip wordt eerst in het kort een schets gegeven van de beroepsmatige somatische en psychiatrische verpleegkunde aan het begin van de twintigste eeuw. Dan volgen het ontstaan en de ontwikkeling van het psychiatrisch-sociaal werk in de Verenigde Staten. Daarna komen het ontstaan en de ontwikkeling van de sociaalpsychiatrische verpleegkunde in Duitsland en in Nederland aan de orde. Duitsland wordt kort meegenomen, omdat de situatie aldaar model staat voor de situatie in Nederland. Het hoofdstuk wordt afgesloten met conclusies en een discussie.

\subsection{De beroepsmatige verpleegkunde}

\subsubsection{De somatische verpleegkunde}

De beroepsmatige somatische verpleegkunde ontstaat in Europa en de Verenigde Staten gedurende de tweede helft van de negentiende eeuw. Aanzetten daartoe zijn gedaan in het, al dan niet religieus geïnspireerde, filantropische werk. De diaconessen in Europa zijn er een voorbeeld van.

Twee grote oorlogen, te weten die op de Krim van 1853-1856 en de FransPruisische oorlog van 1870-1871, laten zien dat verpleegkundigen een rol van betekenis hebben in de zorg voor gewonden. Door het ontstaan van een midden- of burgerklasse neemt de vraag naar betaalde en adequate verpleging toe. Tegelijkertijd groeit het inzicht dat zonder vakbekwame verzorging, met name goede hygiëne, de zieken slecht worden geholpen. Hoewel chirurgie en interne geneeskunde nog aan hun grote opmars moeten beginnen, zijn het de medici in de ziekenhuizen die leiding geven aan het invoeren van nieuwe werkwijzen en technieken. Zij krijgen behoefte aan hulpkrachten die kunnen lezen en schrijven en die kunnen worden geschoold. Die vinden ze in vrouwen uit de "betere kringen". ${ }^{123}$

Onder leiding van artsen wordt scholing opgezet en er ontstaat een langzaam groeiende groep opgeleide verpleegkundigen. In Nederland worden in 1879 de eerste diploma's uitgereikt door de Vereeniging van Ziekenverpleging te Amsterdam. De gediplomeerden worden ingezet voor het leiden en reorganiseren van de Am-

\footnotetext{
${ }^{123}$ Abel-Smith B. (1979). A history of the nursing profession. London: Heinemann, 57. Bakker- van der Kooij, C. (1981). Mara, pleegzuster zijn: ontwikkelingen in de ziekenverpleging en de organisatiepogingen van verpleegsters in Nederland 1870-1920. In J. Blok, M. Elias, E. Kloek, S. Leyesdorff, J. Poelstra, J. Quast, J. Reijs, \& Y. Scherf, Jaarboek voor vrouwengeschiedenis, 1981. Nijmegen: Socialistische Uitgeverij, 195. Wiegman, N. (1998). De verpleegster zij in de eerste plaats vrouw van karakter: ziekenverpleging als vrouwenzaak. In R. van Daalen, \& M. Gijswijt-Hofstra, Gezond en wel: vrouwen en de zorg voor gezondheid in de $20^{\text {ste }}$ eeuw. Amsterdam: Amsterdam University Press, 129. Panke-Kochinke, B. (2001). Die Geschichte der Krankenpflege 1679-2000: ein Quellenbuch. Frankfurt am Main: Mabuse Verlag, 27. Roberts, M.M. (1954). American nursing: history and interpretation. New York: Macmillan.
} 
sterdamse gasthuizen en voor de zorg met betrekking tot besmettelijke ziekten. ${ }^{124}$ In Engeland is de Nightingale Training School, meer nog dan een opleiding tot verpleegkundige, een kweekvijver voor leidinggevenden. ${ }^{125}$ De school, overigens niet de enige opleiding in Engeland reikt 1907 diploma's uit tussen 1860 en 1903. Nederland telt in 1900913 gediplomeerden, waarvan 48 man. De inhoud van de opleidingen is vooral gericht op het praktische werk. "Van anatomie, fysiologie, hygiëne en de beginselen der pathologie zal dan ook slechts zoveel geëist mogen worden als strikt noodzakelijk is om de verpleegsters tot denkende practicae te maken...". ${ }^{126}$

Het werk is zwaar, wordt in de sfeer van roeping getrokken en bestaat voor een groot deel uit het handhaven van basale hygiëne en huishoudelijke arbeid. ${ }^{127}$ Het verloop is groot. Vrouwen die gaan trouwen, mogen veelal niet blijven werken. Anderen gaan aan de slag als vrijgevestigde in de thuiszorg. Met name de Amerikaanse verpleegkundigen doen dat massaal. ${ }^{128}$ Meer nog dan in Nederland, Engeland of Duitsland wordt als gevolg hiervan het werk op de ziekenhuisafdelingen in de Verenigde Staten voor een groot deel gedaan door leerling-verpleegkundigen en door ongeschoolden.

Door de toenemende vraag naar verpleegkundigen stromen er lager of niet opgeleide vrouwen in en neemt de afstand tussen de eerste en de tweede generatie verpleegkundigen toe. De eerste neemt de leidinggevende posities in en handhaaft een strakke discipline, daarbij gesteund door de medici. ${ }^{129}$ Het feit dat de verpleegkundigen bij het ziekenhuis zijn gehuisvest, draagt bij aan bijna 24 uur sociale controle per etmaal. De invloed gaat nog verder, getuige een opmerking uit de kring van de Royal British Nurses Association, namelijk dat het afhangt van de leidinggevende verpleegkundige van het ziekenhuis of verpleegkundigen wel of geen lid van de vereniging worden. ${ }^{130}$

Rond 1920 wordt de bemoeienis van de overheid met de opleidingen een feit. In Engeland wordt in 1919 de opleiding tot somatisch verpleegkundige wettelijk geregeld met de Nurses Registration Act. Vanaf 1921 kent het land Pruisen een tweejarige opleiding die in 1938 in heel Duitsland wordt ingevoerd. ${ }^{131}$ In Nederland komt

\footnotetext{
${ }^{124}$ Bakker-van der Kooij, C. Mara, pleegzuster zijn: ontwikkelingen in de ziekenverpleging en de organisatiepogingen van verpleegsters in Nederland 1870-1920, 197.

${ }^{125}$ Abel-Smith, B. A history of the nursing profession, 24.

${ }^{126}$ Binnenkade, C. (1973). Honderd jaar opleiding tot verpleegkundige in Nederland 1872-1972. Leiden: Stafleu's Wetenschappelijke Uitgeversmaatschappij, 12.

${ }^{127}$ Bakker-van der Kooij, C. Mara, pleegzuster zijn: ontwikkelingen in de ziekenverpleging en de organisatiepogingen van verpleegsters in Nederland 1870-1920, 211. Pancke-Kochinke, B. Die Geschichte der Krankenpflege 1679-2000: ein Quellenbuch, 30.

${ }^{128}$ Davies, C. (1980). A constant casualty: nurse education in Britain and the USA to 1939. In C. Davies (ed.), Rewriting nursing history. London: Croom Helmes/Totowa: Barnes \& Noble, 113.

${ }^{129}$ Wiegman, N. De verpleegster zij in de eerste plaats vrouw van karakter: ziekenverpleging als vrouwenzaak 1898-1998, 305.

${ }^{130}$ Abel-Smith, B. A history of the nursing profession, 65-66.

${ }^{131}$ Weisbrod-Frey, H. (2001). Die Krankenpflegeausbilung im zeitlichen Überblick. In H. Steppe (ed.), Krankenpflege im Nazionalsozialismus. Frankfurt am Main: Mabuse Verlag, 111.
} 
in 1921 de Wet tot bescherming van het diploma voor ziekenverpleging tot stand. "Het diploma kan gelden, hetzij voor de gewone ziekenverpleging in welk geval het als diploma $A$ wordt aangeduid, hetzij voor de verpleging van zenuwzieken en krankzinnigen, in welk geval het als diploma B wordt aangeduid". ${ }^{132}$ Op 1 januari 1924 treedt de wet in werking. De vooropleidingseis wordt landelijk geregeld in 1929; vanaf dan moeten leerling-verpleegkundigen minimaal lagere school hebben gevolgd. Met het wettelijk regelen van de opleiding is dus niet gezegd dat het ontwikkelingsniveau van degenen die de opleiding volgen, hetzelfde is.

Vrijwel meteen na het ontstaan van de opleidingen beginnen verpleegkundigen zich te organiseren in beroeps- en belangenverenigingen en worden vaktijdschriften uitgegeven. Groot-Brittannië kent sinds 1887 de British Nurses' Association, die later het predicaat Royal krijgt. In 1897 wordt de Nurses Associates Alumnae of the United States and Canada opgericht, in 1911 omgedoopt tot de American Nurses' Association. De International Council of Nurses wordt in 1899 opgericht. In Nederland bestaat sinds 1890 het Maandblad voor Ziekenverpleging, later Tijdschrift voor Ziekenverpleging genoemd, nu TVZ Tijdschrift voor Verpleegkundigen geheten. Het is een initiatief van artsen en de "eerste generatie verpleegkundigen" zoals Jeltje de Bosch-Kemper, en is bedoeld om mensen die geïnteresseerd zijn in de ziekenverpleging bij elkaar te brengen. Nosokómos, Vereeniging tot Bevordering van de Belangen van Verpleegsters en Verplegers, wordt in 1900 opgericht. Initiatiefnemers zijn onder anderen Aletta Jacobs, arts, Arnold Aletrino, arts en journalist en zijn vrouw Julia van Stockum, verpleegster. ${ }^{133}$

\subsubsection{De psychiatrische verpleegkunde}

De psychiatrische verpleegkunde als beroepsmatige vorm van zorgverlening ontstaat niet veel later dan de somatische verpleegkunde.

Met de biomedische oriëntatie die aan het eind van de negentiende eeuw opkomt in de psychiatrie, wordt de behandeling van patiënten in toenemende mate op somatische leest geschoeid. Zoals dat ook in het ziekenhuis het geval is, worden rust en hygiëne belangrijk. ${ }^{134}$ Bed- en badverpleging worden belangrijke behandelvormen, naast slaap- en kalmeringsmiddelen. Om de psychiaters te helpen bij het uitvoeren van de somatische therapievormen, is ander en beter opgeleid personeel nodig dan alleen maar oppassers en zaalmeiden.

Net zoals dat het geval is in de somatische gezondheidszorg, gaan ook in de psychiatrie de artsen opleidingen voor verpleegkundigen opzetten. De voor zover

\footnotetext{
${ }^{132}$ Laat, F.C.M. de (s.a.). Van psychiatrisch verpleegkundige naar ... : een historisch overzicht van de ontwikkelingen rond de psychiatrische verpleegkunde in de periode 1920-1980. Doctoraalscriptie Universiteit van Amsterdam, 11.

${ }^{133}$ Binnenkade, C. Honderd jaar opleiding tot verpleegkundige in Nederland 1872-1972, 12.

134 Boschma, G. (1997). Psychiatrische verpleegkunde: een historisch perspectief. Maandblad Geestelijke Volksgezondheid, 52, 959-976, 961-962.
} 
bekend eerste opleidingsschool ter wereld begint met onderwijs in 1882. Het is de McLean Asylum Training School for Nurses in Waverly, Massachusetts. ${ }^{135}$ In 1886 krijgen vijftien vrouwen het diploma en beginnen de eerste mannen aan de opleiding. De opleiding is gericht op basale lichamelijke verzorging, huishoudelijk werk, handhaving van de orde en observatie ten behoeve van de psychiatrische diagnostiek. $^{136}$

In Nederland begint Van Deventer, geneesheer-directeur van het Binnengasthuis in Amsterdam en eerder betrokken bij het opzetten van een opleiding voor somatisch verpleegkundigen, in 1883 een cursus krankzinnigenverpleging. De nadruk ligt ook hier op de praktijk. "De kunst om te helpen verplegen, de verplegingstechniek, moet practisch worden geleerd". ${ }^{137}$ De Nederlandse Vereniging voor Psychiatrie vormt in 1889 een commissie die advies moet geven inzake de verbetering van het niveau van het personeel in de krankzinnigengestichten. Dat niveau is erg laag en er is veel verloop. ${ }^{138}$ In 1892 wordt er een begin gemaakt met een opleiding tot verplegende. In 1893 heeft elk krankzinnigengesticht een opleiding, al dan niet in samenwerking met de Nederlandse Vereniging voor Psychiatrie. Nederland kent in 1908 meer dan zes verschillende mogelijkheden om een diploma te behalen, waaronder die van de Nederlandsche Bond voor Ziekenverpleging, de Vereeniging Nosókomos en de Rooms-katholieke instellingen. ${ }^{139}$

De "Verein Deutscher Irrenärzte" spreekt zich in 1896 uit voor een beroepsmatige verpleging en voor uniformering en verhoging van de kwaliteit van de opleiding. De nieuwe opleiding, die vijf maanden zal gaan duren, moet zich richten op hygiëne, orde, netheid, verpleging van krankzinnigen en algemene ontwikkeling. ${ }^{140}$ Inrichtingen bieden in die tijd bijscholing in lezen, schrijven en rekenen. Vrouwelijke verpleegkundigen krijgen daarbij afwisselend een week les in de keuken en de wasserij. ${ }^{141}$

\footnotetext{
${ }^{135}$ Peplau, H.E. (1989). Future directions in psychiatric nursing from the perspective of history. Journal of Psychosocial Nursing, 27, 18-27, 18.

${ }^{136}$ May, M.E. (1893, herdruk 1949). Nursing of the insane. In I.A. Hampton et al. (eds.), Nursing of the sick. New York: McGraw Hill, 179.

${ }^{137}$ Weisglas, M. (1981). De overgang van oppassers en oppasseressen naar verplegers en verpleegsters in de krankzinnigengestichten 1880-1921. Doctoraalsriptie Nieuwe Geschiedenis, Universiteit van Amsterdam, 69.

${ }^{138}$ Boschma, G. (1999). High ideals versus harsh reality: a historical analysis of mental health nursing in Dutch asylums 1890-1920. Nursing History Review, 7, 127-151, 135.

${ }^{139}$ Geneeskundige Inspectie voor de Geestelijke Volksgezondheid (1993). 100 Jaar diploma Bverpleegkundige. Rijswijk: Staatstoezicht op de Volksgezondheid, 18.

${ }^{140}$ Falkenstein, D. (2000). "Ein guter Wärter is das vorzüglichste Heilmittel... .": zur Entwicklung der Irrenpflege vom Durchgangs- zum Ausbildungsberuf. Frankfurt am Main: Mabuse Verlag, 30.

${ }^{141}$ Möllenhoff, H. (1992). Zur Geschichte des Pflegepersonals. In P. Eller, \& C. Vanja (Hrsg.), Psychiatrie in Heppenheim: Streifzüge durch die Geschichte eines hessischen Krankenhauses 1866-1991. Kassel: Landeswohlfartverband Hessen, 134.
} 


\subsubsection{De invloed van de psychiaters}

Uit de door psychiaters geschreven leerboeken wordt duidelijk hoe zij de rol van de verpleegkundigen zien. Orde, netheid, geduld, het goede voorbeeld geven en bovenal gehoorzaamheid aan de psychiater: dat zijn de eisen die worden gesteld.

Het Engelse "Handbook for the instruction of attendants of the insane" uit 1885 komt pas toe aan de verpleging van psychiatrische patiënten als de andere onderwerpen, zoals anatomie en fysiologie, uitputtend zijn behandeld. ${ }^{142}$ De Royal Medico-Psychological Association begint in 1891 een opleiding waarin de nadruk meer ligt op beheersaspecten dan op het opleiden van beroepsbeoefenaren. ${ }^{143}$

In 1899 verschijnt in Duitsland van de hand van de psychiater Scholz "Leitfaden für Irrenpfleger". De genegenheid en het vertrouwen van de patiënten zullen de verpleegkundigen die voldoen aan het ideaalbeeld ten deel vallen, zo schrijft de auteur. $^{144}$

De door psychiaters geschreven leerboeken die in Nederland tussen 1906 en 1934 worden uitgegeven, zien er in grote lijnen hetzelfde uit als de hiervoor genoemde. ${ }^{145}$ De twee delen van de "Handleiding voor den cursus in de verpleging van Zielszieken" van Cox zijn een mengeling van woordenboek, aandrager van algemene ontwikkeling, reisgids en algemeen leerboek voor de verpleging van geesteszieken. "Lucifer is afgeleid van lux en fere (lat.); het beteekent lichtdrager. De Zweden noemen een lucifer tändstickor, dat overeenkomt met een tondelstokje ..." ${ }^{146}$ Cox drukt zijn lezers op het hart om zich cultureel te oriënteren en, indien ze naar Java op vakantie gaan, vooral de Borobodur te bezoeken.

Ofschoon in de Verenigde Staten in 1920 een door de verpleegkundige Harriet Bailey geschreven leerboek over psychiatrische verpleegkunde wordt uitgegeven, doet dat niet af aan de leidende rol die de psychiaters ook daar hebben als het om de leerboeken en de opleiding gaat. ${ }^{147}$ "By this time the psychiatrist had succesfully co-opted the control of the standardization of the majority of training programs

\footnotetext{
${ }^{142}$ Walk, A. (1961). The history of mental nursing. The Journal of Mental Science, 107, 1-17, 12.

${ }^{143}$ Peplau, H.E. (1982). Historical development of psychiatric nursing: a preliminary statement of some facts and trends. In S.A. Smoyak, \& S. Rouslin (eds.), A collection of classics in psychiatric nursing literature. Thorofare: Charles B. Slack, 12.

${ }^{144}$ Falkenstein, D. "Ein guter Wärter ist das vorzüglichste Heilmittel... .": zur Entwicklung der Irrenpflege vom Durchgangs- zum Ausbildungsberuf, 76.

${ }^{145}$ Scheffer, J.C.Th. (1906). Voorlezingen over zenuwzieken en krankzinnigen en hunne verpleging. Haarlem: De Erven F. Bohn. Schnitzler, G.J. (1915). Krankzinnigen en hunne verpleging: een leidraad voor krankzinnigenverpleegsters. Amsterdam: J.H. Debussy. Schnitzler, G.J. (1926). Krankzinnigen en hunne verpleging: een leidraad voor verplegenden in krankzinnigengestichten. Amsterdam: J.H. Debussy. Cox, W.H. (1927). Handleiding voor den cursus verpleging van zielszieken, Deel 1: Eerste cursusjaar. Amsterdam: Tijdschrift voor Ziekenverpleging/J.H. Debussy. Cox, W.H. (1929). Handleiding voor den cursus in de verpleging van zielszieken, Deel II: Tweede cursusjaar. Amsterdam: Tijdschrift voor Ziekenverpleging/J.H. Debussy. Schim van der Loeff, H.J., \& Barnhoorn, J.A.J. (1932). Zielszieken en hunne verpleging. Roermond; Maaseyck: J.J. Roomen en Zonen.

${ }^{146}$ Cox, W.H. Handleiding voor den cursus in de verpleging van zielszieken, Deel II: Tweede cursusjaar, 77.

${ }^{147}$ Peplau, H.E. Future directions in psychiatric nursing from the perspective of history, 20.
} 
through their self-appointed Committee on Psychiatric Nursing and were firmly entrenched as the authority on psychiatric nursing" ${ }^{148}$

De invloed van psychiaters op het daadwerkelijke gedrag van verpleegkundigen kan overigens worden gerelativeerd. Regenten en bestuurders, in Nederland onder meer van protestantse en katholieke huize, hebben grote invloed op het beleid in de inrichtingen, en daarmee op hun beurt ook op de invloed die psychiaters hebben op verpleegkundigen. Daar komt bij dat verpleegkundigen, zoals dat ook nu nog het geval is, het grootste deel van de tijd werken in afwezigheid van de psychiaters. Ze hebben voldoende ruimte om hun concrete activiteiten naar eigen inzicht in te richten.

De groei van het aantal opleidingen en gediplomeerden verloopt langzaam: in de Verenigde Staten respectievelijk 35 en 471 in $1891 .{ }^{149}$ In 1915 bieden 41 inrichtingen in Amerika een programma aan. Rond die tijd ontstaan de undergraduate programs voor psychiatrisch verpleegkundigen. Volgens de National League of Nursing Education wordt in 1928 de meeste zorg verleend door "trained or untrained attendants, maids, orderlies, or fellow patients". ${ }^{150}$

In Engeland worden aan het eind van de negentiende eeuw per jaar rond de 600 diploma's uitgereikt. ${ }^{151}$ Het land heeft in 1922108.646 psychiatrische bedden en zo'n 2700 gediplomeerd verpleegkundigen. Veel leidinggevenden zijn niet geschoold. ${ }^{152}$

\subsubsection{Het imago van de psychiatrische verpleegkunde}

Het imago van het beroep is slecht. De normen voor de opleiding zijn lager dan die in algemene ziekenhuizen, evenals de salarissen. Werkdagen van veertien uur zijn geen uitzondering. Het werk is zwaar huishoudelijk van aard. De leefomstandigheden zijn slechter dan in de somatische zorg; de instellingen liggen ver van de bewoonde wereld en patiënten en verpleegkundigen wonen vaak op dezelfde afdeling.

De verhoudingen zijn sterk hiërarchisch. Het Duitse blad "Irrenpflege" van 1930 geeft gedragsvoorschriften voor verpleegkundigen. "Ein Sprechen mit Handbewegungen ist zu unterlassen, vielmehr sollen die Arme gerade herunterhängen, die Füße zusammengestellt und der Blick gerade auf den Vorgesetzten gerichtet wer-

\footnotetext{
${ }^{148}$ Church, O.M. (1982). That noble reform: the emergence of psychiatric nursing in the United States, 1882-1963. Ann Arbor: University Microfilms International, 31.

${ }^{149}$ Peplau, H.E. Historical development of psychiatric nursing: a preliminary statement of some facts and trends, 12.

${ }^{150}$ Ibidem, 25.

${ }^{151}$ Nolan, P. (1993). A history of mental health nursing. Cheltenham: Stanley Thornes, 68.

152 Ibidem, 84-85.
} 
den". ${ }^{153}$ De verpleegkundige wordt geacht links van de arts te lopen en diens spullen te dragen.

Bij onrustige en gevaarlijke patiënten worden dwangmaatregelen, zoals het gebruik van het mouwvest, veelvuldig toegepast. Een Nederlandse verpleegkundige in de jaren dertig: "De patiënten smeten met tinnen bordjes en bekers... gooiden met koffie,... sloegen ruiten stuk... De shockbehandeling en badverpleging waren voor patiënt en verpleger een gruwel. Van angst voor deze methode wisten de patiënten door hun woede heen niet wat ze deden en gooiden ze tafels en stoelen omver, en natuurlijk deelden wij ook mee door de schoppen die we kregen...". ${ }^{154}$

Uit een onderzoek in vier inrichtingen in de Verenigde Staten, uitgevoerd door de National League of Nursing Education, komt onder andere naar voren dat op een afdeling voor chronisch verwarden één gediplomeerde werkt op 23 patiënten. ${ }^{155}$ In 1940 zijn er in de state mental hospitals 4.252 psychiatrisch verpleegkundigen, hoofdzakelijk vrouwen, werkzaam op ongeveer 435.000 patiënten. ${ }^{156}$ Bij het uitbreken van de Tweede Wereldoorlog wordt de zorg voor patiënten voor het grootste deel nog steeds verleend door "ignorant, short sighted, bulldozing attendants, whose incompetence, callousness and brutality beggar description". ${ }^{157}$

Het verschil tussen de somatische en de psychiatrische verpleegkunde blijkt niet enkel uit de concrete werksituatie. Pogingen om in 1896 in Engeland psychiatrisch verpleegkundigen met een diploma van de Royal Medico-Psychological Association als verpleegkundige geregistreerd te krijgen, mislukken. Mrs. Bedford-Fenwick, oprichter van de Royal British Nursing Association is tegen. Wie in een inrichting heeft gewerkt, wordt beschouwd niet te zijn opgeleid en kan geen verpleegkundige worden genoemd . "... considering the present class of persons known as male attendants, one can hardly believe that their admission will tend to raise the status of the Association, while we foresee considerable trouble for the executive council from such members". ${ }^{158}$

Omdat de algemene ziekenverpleging meer aanzien heeft en beter wordt beloond dan de psychiatrische verpleging, stappen veel verplegenden uit de psychiatrie na verloop van tijd over. In Nederland bij voorbeeld wordt ook na de wettelijke regeling van de diploma's in 1921 voor de A-opleiding nog steeds geworven onder meisjes en vrouwen van betere standen. Bij de werving voor de B-opleiding wordt

\footnotetext{
${ }^{153}$ Falkenstein, D. "Ein guter Wärter ist das vorzüglichste Heilmittel ...": zur Entwicklung der Irrenpflege vom Durchangs- zum Ausbildungsberuf, 77-78.

${ }^{154}$ Peeters, H.F.M., \& Vos, C.P. de (1982). Een historische analyse van een provinciaal psychiatrisch centrum over de periode 1885-1977. In J.M.W. Binneveld, C. Brinkgreve, A.J. Lameijn, H.F.M. Peeters, P. Vandermeersch, C.P. de Vos, \& J. Vijselaar. Een psychiatrisch verleden: uit de geschiedenis van de psychiatrie. Baarn: Amboboeken, 164.

${ }^{155}$ Bailey, H. (1936). Nursing schools in psychiatric hospitals. American Journal of Nursing, 36, 495-508, 501.

${ }^{156}$ Grob, G.N. (1991). From asylum to community: mental health policy in modern America. Princeton: Princeton University Press, 118.

${ }^{157}$ Ibidem, 120.

${ }^{158}$ Nolan, P. A history of mental health nursing, 69.
} 
geen onderscheid gemaakt naar maatschappelijke afkomst. De B-opleiding gaat fungeren als een opstapje naar de $A .{ }^{159}$

In Duitsland geldt de titel "Krankenschwester" lange tijd enkel voor de vrouwelijke werkers in de somatische zorg en niet voor hun collegae in de psychiatrie. ${ }^{160}$ Pas eind jaren vijftig is er in de Bondsrepubliek sprake van formele gelijkschakeling van somatisch en psychiatrisch verpleegkundigen.

\subsection{Psychiatrisch-sociaal werk in de Verenigde Staten}

\subsubsection{Het begin}

Aan het eind van de negentiende eeuw kennen de Verenigde Staten, met name aan de oostkust, een hoge mate van maatschappelijke onrust, veroorzaakt door onder meer grote aantallen immigranten, een zich snel voltrekkend proces van urbanisatie, rassenproblematiek en armoede. Voor de blanke, protestantse Amerikanen met een sterk ontwikkeld arbeidsethos zijn de immigranten "not merely 'other' but directly threatening: loud, drunken, sexually uninhibited, violent and alltogether a threat to 'decent' values and the structure of the American community". ${ }^{161}$ De overheid stelt zich terughoudend op bij het aanpakken van sociale nood en laat dat over aan het particuliere initiatief. ${ }^{162}$ Voortkomend uit de armenzorg, op filantropische basis uitgevoerd door met name vrouwen uit de hogere sociale lagen, ontstaat het maatschappelijk werk. Dat houdt zich van meet af aan bezig met psychiatrische patiënten. In de jaren tachtig van de negentiende eeuw zijn maatschappelijk werkenden betrokken bij de oprichting van de National Association for the Protection of the Insane and the Prevention of Insanity. ${ }^{163}$

De aanpak van maatschappelijk werkenden is niet altijd even subtiel. Zo is er sprake van vergaderingen waarin de buren van de "hulpbehoevende" mee beslissen over het type hulp en hoe dat gegeven moet worden. Na afloop van zo'n bespreking volgt een "interview of persuasion" waarin de maatschappelijk werkster de cliënt probeert te overtuigen het gemaakte plan te accepteren. ${ }^{164}$

\footnotetext{
${ }^{159}$ Geneeskundige Inspectie voor de Geestelijke Volksgezondheid. 100 Jaar diploma B-verpleegkunde, 2223.

${ }^{160}$ Kukla, R. (1973). Zur Sozialisation der Krankenschwestern in der Psychiatrie. Kölner Zeitschrift für Soziologie und Sozialpsychologie, 25, 484-498, 485.

${ }^{161}$ Ehrenreich, J.H. (1985). The altruistic imagination: a history of social work and social policy in the United States. Ithaca; London: Cornell University Press, 22.

${ }^{162}$ Kamphuis, M. (1948). Amerika en wij: wat valt er voor ons maatschappelijk werk te leren? Tijdschrift voor Maatschappelijk Werk, 2, 49-52, 49.

${ }^{163}$ Deutsch, A. (1940). The convergence of social work and psychiatry: a historical note. Mental Hygiene, 24, 92-97, 94

${ }^{164}$ Kamphuis, M. (1948). Het Amerikaanse social case work. Tijdschrift voor Maatschappelijk Werk, 2, 81$85,82$.
} 
Al vroeg organiseert de beroepsgroep een eigen opleiding. De eerste cursus wordt gegeven in 1898 aan de New York School of Philantropy, de latere New York School of Social Work. Daar begint in 1904 een eenjarige opleiding. ${ }^{165}$

Eveneens in 1904 begint de vrouw van de psychiater Adolph Meyer gezinnen van opgenomen patiënten te bezoeken om ten behoeve van de behandeling door haar man informatie te verzamelen over de leefomstandigheden. ${ }^{166}$ Meyer is, zoals in hoofdstuk 2 is gebleken, de mening toegedaan dat sociale factoren meegenomen moeten worden in diagnostiek en behandeling van psychiatrische problemen.

In 1906 treedt de New York State Care Act in werking, die voorziet in nazorgcomité's bij de state mental hospitals. Voor die nazorg worden maatschappelijk werkenden ingezet. Andere psychiatrische ziekenhuizen volgen. ${ }^{167}$ Het aantal nazorgdiensten in de staat New York is in 1927 gegroeid tot boven de $50 .{ }^{168}$ Zo ontstaat er langzaam vraag naar geschoolde hulpverleners.

Die vraag neemt merkbaar toe als er militairen met psychische problemen terugkeren uit de Eerste Wereldoorlog. De problematiek van de veteranen draagt bij aan de opvatting om veel psychiatrische problemen, evenals andere moeilijkheden, te zien als mede veroorzaakt door omstandigheden. ${ }^{169}$ Ook op andere terreinen, zoals de jeugdzorg en de reclassering, ontstaat vraag naar maatschappelijk werkenden met een psychiatrische achtergrond. Psychiatrie en "mental hygiene" worden in de jaren twintig erg populair. "In the enthousiasm of the moment, psychiatry and mental hygiene came to be regarded as cure-alls for every ill in the world". ${ }^{170}$

\subsubsection{De opleiding}

De eerste opleiding tot psychiatrisch-sociaal werker begint in 1918. Initiatiefnemers zijn de psychiater Southard en de maatschappelijk werkster Jarrett. ${ }^{171}$ Het rooster van de cursus sociale psychiatrie levert de volgende onderwerpen: fysieke oorzaken van geestelijke ziekten, afnemen van de anamnese, lichtbeelden van hersenbeschadigingen, epilepsie en de epileptische make-up, hysterie, constitutionele inferioriteit, psychopathische persoonlijkheden, psycho-neurosen, manisch-depressieve stoornissen, alcoholisme en alcoholpsychose, dementia praecox, paranoïde toestandsbeeld, oorlogsneuroses en psychoses. De opleiding probeert duidelijk te

\footnotetext{
${ }^{165}$ Waaldijk, B. (1996). Het Amerika der vrouw: sekse en geschiedenis van maatschappelijk werk in Nederland en de Verenigde Staten. Groningen: Woltergroep, 148.

${ }^{166}$ Lubove, R. (1983). The professional altruist: the emergence of social work as a career 1890-1930. New York: Atheneum, 62.

${ }^{167}$ Dorgan, R.E. (1970/71). From demonology to scientific humanitarianism: social casework specializes. International Journal of Psychiatry, 17, 20-38, 35.

${ }^{168}$ Frankenstein, G. (1927). Psychiatrische Sozialarbeit in den Vereinigten Staaten von Amerika. Zeitschrift für die Gesamte Neurologie und Psychiatrie, 325-336, 329.

169 Meyer, A. (1922). Historical sketch and outlook of psychiatric social work. Hospital Social Science, 5, 221-225, 223.

${ }^{170}$ Deutsch, A. The convergence of social work and psychiatry: an historical note, 96.

${ }^{171}$ French, L.M. (1940). Psychiatric social work. New York: The Commonwealth Fund, 40.
} 
maken "to what degree abnormal and antisocial behavior results from the inability to make ... adjustments of primitive instincts to modern civilization" ${ }^{172}$

De opleidingen zijn, in navolging van Meyer's ideeën over het ontstaan en de behandeling van psychiatrische problemen, en in het kielzog van de beweging voor Mental Hygiene, sterk op de sociale omgeving georiënteerd. ${ }^{173}$ Dat kan niet enkel worden toegeschreven aan Meyer of de "mental hygiene-movement", maar ook aan het maatschappelijk werk zelf. Dat heeft een eigen methodiek ontwikkeld, het "social case work". Het is in 1917 door Richmond gedefinieerd als "those processes which developed personality through adjustments consciously effected, individual by individual, between men and their social environment ${ }^{\prime \prime}{ }^{174}$ Sociaal onderzoek, diagnostiek en behandeling, met de nadruk op gespreksvoering, maken er deel van uit. De behandeling van psychiatrische problemen kan echter niet worden overgelaten aan maatschappelijk werkenden alleen. Als er een conflict ontstaat tussen sociale en medische belangen beslist de psychiater, omdat de behandeling van psychiatrisch zieken primair een medische aangelegenheid is. ${ }^{175}$

De social workers vormen blijkbaar een zelfbewuste beroepsgroep. Ze zijn, volgens Southard, beschaafder en beter opgeleid dan verpleegkundigen en voelen zich superieur ten opzichte van die laatste groep. Hij noemt het verbazingwekkend dat "the practical social worker has so soon taken her high place in the world alongside the nurse". ${ }^{176}$

De beroepsgroep ontwikkelt zich snel. Er komen opleidingen, waarvan al in 1928 een aantal aan colleges en universiteiten. ${ }^{177}$ Handboeken worden geschreven, een beroepsvereniging wordt in 1926 opgericht. Deze American Association of Psychiatric Social Workers (AAPSW) omschrijft het aandachtsveld. "Social treatment in psychiatric social work, as in other social work, means the supervision of the patient in the community in such a way as to bring about a better adjustment for him". ${ }^{178}$ Soms is er niet meer mogelijk dan het aanpassen van de patiënt aan de omgeving. In een aantal gevallen is het mogelijk gedragsveranderingen bij de cliënt te bewerkstelligen. Vaak echter komen de psychiatrisch-sociaal werkenden niet verder dan het verzamelen van uitgebreide informatie over zowat alle aspecten van het leven van de cliënt, zijn familie en zijn woon- en werkomgeving.

\footnotetext{
${ }^{172}$ Spaulding, E.R. (1918). The training school of psychiatric social work at Smith College: the course in social psychiatry. Mental Hygiene, 2, 585-590, 586.

${ }^{173}$ Dorgan, R.E. From demonology to scientific humanitarianism: social casework specializes, 37.

${ }^{174}$ French, L.M. Psychiatric social work, 34.

${ }^{175}$ Odencrantz, L.C. (1929). The social worker in family, medical and psychiatric social work. New York: Harper \& Brothers, 271.

${ }^{176}$ Southard, E. (1918). Mental hygiene and social work: notes on a course in social psychiatry for social workers. Mental Hygiene, 2, 388-406, 389.

${ }^{177}$ Larkin K.O. (1931). What education does the psychiatric social worker need? Psychiatric Quarterly, 5, 723-732, 724.

${ }^{178}$ Odencrantz, L.C. The social worker in family, medical and psychiatric social work, 292.
} 
Als in de loop van de jaren twintig het psycho-analytische gedachtegoed terrein begint te winnen, treedt er een verschuiving op in het aandachtsgebied van de psychiatrisch-sociaal werkenden. Niet langer is het probleem in relatie tot de omgeving, maar het probleem in relatie tot de persoon het aangrijpingspunt. "Toward the end of the 20', psychiatric casework would 'roaringly' embrace the psychoanalytic model and embarc new spheres and treatment focus". ${ }^{179}$ Psychiatrisch-sociaal werkers vervreemden van niet-psychoanalytisch georiënteerde psychiaters. Velen verlaten de nazorg en gaan werken bij onder andere instellingen voor maatschappelijk werk en medisch-opvoedkundige bureaus, die nieuwe mogelijkheden bieden.

De psycho-analytische oriëntatie blijft niet enkel beperkt tot de psychiatrischsociaal werkenden, maar vindt plaats in de hele beroepsgroep van het maatschappelijk werk. Er wordt gesproken van "Freudianization". Het aanzien van de psychiatrisch-sociale stroming binnen de beroepsgroep groeit daardoor. "The psychiatric social worker has emerged as the queen of case workers, for if her point of view was relevant to all case work, then no other was better qualified by training and experience to speak for the profession" ${ }^{180}$

In 1929 zijn er naar schatting tussen de drie- en vierhonderd psychiatric social workers in de Verenigde Staten, waarvan 175 lid van de AAPSW. De Association heeft in 1938 iets meer dan 500 leden. ${ }^{181}$ De werkomgeving van die leden, en daarmee waarschijnlijk ook van de niet georganiseerde werkers, varieert: sociaalpsychiatrische diensten, child guidance clinics, algemene ziekenhuizen, scholen, bureaus voor maatschappelijk werk, psychiatrische ziekenhuizen, organisaties voor extramurale verpleging enzovoorts. Ongeveer de helft houdt zich nog bezig met maatschappelijk werk in combinatie met psychiatrie in de zin van nazorg. ${ }^{182}$

Voor de beroepsgroep wordt het omschrijven van de taakinhoud er met de psycho-dynamische oriëntatie blijkbaar niet duidelijker op. Tijdens een vergadering van de AAPSW in 1942 lukt het niet goed om te onderscheiden welke gevallen typisch voor de psychiater zijn en welke voor de psychiatrisch-sociaal werker. De conclusie luidt "that we hardly know what it is we psychiatric social workers do". ${ }^{183}$ Voor de praktijk levert dat geen onoverkomelijke problemen op. De psychiatrisch-sociaal werkenden doen veel organisatorisch werk, houden de intakegesprekken en verwijzen op basis daarvan de cliënten al dan niet door. De psychiaters, klein in aantal, komt dat goed uit. Ze geven graag de ruimte. ${ }^{184}$

Anders dan in Duitsland en Nederland spelen verpleegkundigen geen rol van betekenis in de Amerikaanse sociale psychiatrie van voor de Tweede Wereldoorlog.

\footnotetext{
${ }^{179}$ Dorgan, R.E. From demonology to scientific humanitarianism: social case work specializes, 37.

${ }^{180}$ Lubove, R. The professional altruist: the emergence of social casework as a career 1880-1930, 86.

${ }^{181}$ French, L.M. Psychiatric social work, 47.

182 Ibidem, 7.

${ }^{183}$ Grob, G.N. From asylum to community: mental health policy in modern America, 115.

${ }^{184}$ Ibidem, 115.
} 
Psychiatrische verpleegkunde speelt zich af in de inrichtingen. ${ }^{185}$ "It was not the public health nurse but the social worker whose professional equipment was more nearly adequate for the required task". ${ }^{186}$ Het specialisme "community mental health nursing" ontwikkelt zich pas vanaf het van kracht worden van de Community Mental Health (Centers Construction) Act in $1963 .^{187}$

\subsection{Sociaalpsychiatrische verpleegkunde in Duitsland en Nederland}

Met de toegenomen oriëntatie van de psychiaters op de wereld buiten de inrichting en hun pogingen om patiënten buiten de inrichtingen te laten verblijven, ontstaat, evenals eerder bij de artsen in de ziekenhuizen en in de inrichtingen, behoefte aan ondersteunend personeel. In Duitsland en Nederland valt de keuze op verpleegkundigen.

\subsubsection{Sociaalpsychiatrische verpleegkunde in Duitsland}

In Duitsland worden kort voor de Eerste Wereldoorlog in steden als Berlijn, Essen en Frankfurt "Zentralen für private Fürsorge" in het leven geroepen. "Die eigentliche Arbeit, Beratung der hilfesuchenden Kranken und Angehörigen, Beschaffung von Schlafstellen und Arbeitsgelegenheit, Verteilung von Unterstützungen, lag auf den Schultern eines fest angestellten Fürsorgers...". ${ }^{188}$ De bedoeling is dat de inrichtingen patiënten die worden ontslagen, naar deze hulpverlener verwijzen. Na een onderbreking door de oorlog wordt, wat Raecke "die soziale Psychiatrie" noemt, verder ontwikkeld. Indien de nazorg niet wordt geregeld vanuit de inrichting, worden er "Wohlfahrtspflegerinnen" ofwel maatschappelijk werksters ingeschakeld bij de nazorg. Ze richten zich met name op zaken als huisvesting, werk, juridische problemen, belastingen en voogdij. Als voorbereiding op hun werk lopen ze een week stage in een inrichting.

Nazorg vanuit de inrichtingen wordt verricht door psychiatrisch verpleegkundigen. Vrouwen hebben de voorkeur boven mannen en vormen dan ook de overgrote meerderheid. "Um es kurz zu sagen, die Frau eignet sich ceteris paribus besser zum Fürsorgedienst wie der Mann... Da bei ihr die allgemeinen Gefühlsmomente besser ausgeprägt sind als der kühl rechnende Verstand, eignet sie sich besser für soziale

\footnotetext{
${ }^{185}$ Church, O.M. (1986). From custody to community in psychiatric nursing. Nursing Research, 36, 48-55, 51.

${ }^{186}$ Anderson, G.L. (1930). The scope and aim of a mental hygiene program in a public health nursing association. Public Health Nurse, 22, 377-379, 377.

${ }^{187}$ Walgrove, N.J. (1986). Mental health after care: where is nursing? Nursing Clinics of North America, 21, 473-481, 474.

${ }^{188}$ Raecke, J. (1921). Moderne Irrenfürsorge und soziale Psychiatrie. Westdeutsche Ãrztezeitung, 12, 48, 48.
} 
Betätigung...". ${ }^{189}$ Als eis wordt gesteld langdurige ervaring als verpleegkundige in een psychiatrische instelling. Indien blijkt dat men zich heeft verkeken op de geschiktheid van de persoon kan ze weer terug naar de inrichting.

Tot het takenpakket van de verpleegkundige horen: het bezoeken van patiënten in nazorg op aanwijzing van de psychiater; het natrekken van de toestand van patienten die op het punt staan ontslagen te worden en in nazorg te komen; in voorkomende gevallen het uitvoeren van lichamelijke verzorging; het begeleiden van transporten; het bijhouden van de administratie; hulp tijdens het spreekuur en het verrichten van voorkomende werkzaamheden. Bij de huisbezoeken is het belangrijk dat de verpleegkundigen de patiënten motiveren om naar het spreekuur van de psychiater te gaan, zodat deze niet naar de patiënt thuis hoeft, waarmee wordt voorkomen dat hij de vrijgevestigde psychiater voor het hoofd stoot. ${ }^{190}$

De al in het vorige hoofdstuk aangehaalde politieke ontwikkelingen in Duitsland vanaf het begin van de jaren dertig belemmeren de verdere ontwikkeling van de sociaalpsychiatrische verpleegkunde. Het duurt tot in de jaren zeventig eer de sociale psychiatrie, vaak "Gemeinde-nahe Psychiatrie" genoemd, zich weer begint te ontwikkelen. Dat geldt ook voor de sociaalpsychiatrische verpleegkunde.

\subsubsection{Sociaalpsychiatrische verpleegkunde in Nederland}

\subsubsection{Het begin}

In Nederland kan het ontstaan van de sociaalpsychiatrische verpleegkunde worden gesitueerd in 1917, als Meijers bij zijn Consultatiebureau voor Zenuw- en Zielszieken in Amsterdam een verpleegkundige betrekt bij extramurale activiteiten ten behoeve van psychiatrische patiënten.

De in 1924 door hem opgerichte "Centrale Vereeniging ter Behartiging van de Maatschappelijke Belangen van Zenuw- en Zielszieken" heeft binnen enkele jaren zestien consultatiebureaus met een "psychiater-leider" en een "verpleegkundige als assistent". De vereniging richt zich vanaf haar oprichting op het bijscholen van wijkverpleegkundigen. Doel is hen kennis bij te brengen van psychiatrische ziektes, zodat ze kunnen worden ingeschakeld als hulpkrachten bij de consultatiebureaus en bij het opsporen van geesteszieken in de maatschappij. ${ }^{191}$

Het in 1928 gepubliceerde boek "Verzorging van zenuw- en zielszieken in de maatschappij" van Beijerman is een weergave van de cursussen van de Centrale

\footnotetext{
${ }^{189}$ Faltlhauser, V. (1927). Die speziellen Gesichtspunkte für die Organisation der offenen Geisteskrankenfürsorge: Fürsorgepfleger. In H. Roemer, G. Kolb, \& V. Faltlhauser (Hrsg.), Die offene Fürsorge in der Psychiatrie und ihren Grenzgebieten: ein Ratgeber für Ärzte, Sozialhygieniker, Nationalökonomen, Verwaltungsbeamte sowie Organe der öffentlichen und privaten Fürsorge. Berlin: Julius Springer, 214.

190 Ibidem, 213.

${ }^{191}$ Grinten, T.E.D. van der (1987). De vorming van de ambulante geestelijke gezondheidszorg: een historisch beleidsonderzoek. Baarn: Ambo, 46.
} 
Vereeniging. De nadruk ligt op basale psychopathologie, kennis van ziektebeelden, enige wetskennis en kennis van de sociale kaart. Bij "de nerveuze mensch" die nog niet ziek is, maar dat wel kan worden, ziet Beijerman een rol voor de wijkverpleegkundige weggelegd. Belangrijk is het verstrekken van informatie omtrent de sociale toestand van de patiënt en diens omgeving aan de arts. "Meeleven, geruststellen, bemoedigen en beleeren, is de beste verpleegkunde bij den zenuwlijder... Zij zal voorts leiding kunnen geven bij het opvolgen van de voorschriften om systematisch te leven en te arbeiden en onbevredigde verlangens te neutraliseren door het aankweken van liefhebberijen". ${ }^{192}$ Een en ander dient te gebeuren volgens voorschrift van de arts. De verpleegkundige moet beschikken over een warm hart en geschiktheid voor het werk. Een goed karakter is daarbij belangrijker dan verstand en kennis. Beijerman besluit met de waarschuwing dat de "werkelijke" verpleging van psychiatrische patiënten voorbehouden blijft aan psychiatrisch verpleegkundigen en dat de wijkverpleegkundige bij elke verandering in het gedrag van de patiënt de arts dient te consulteren. Behalve de Centrale Vereeniging beginnen ook kruisorganisaties en scholen voor maatschappelijk werk dergelijke cursussen. ${ }^{193}$

Bij de buitendienst van Maasoord in Rotterdam, die Pameijer in 1926 begint, worden ervaren inrichtingsverpleegkundigen aangetrokken. Het diploma krankzinnigenverpleging is voorwaarde en het diploma algemene verpleging wordt aanbevolen. Ook in Rotterdam zijn persoonskenmerken belangrijker dan kennis en vaardigheden. "Voor een functie als deze moet een verpleegster bovenal aanleg hebben, moet ze beschikken over eigenschappen, die niet zijn aan te leeren, in de allereerste plaats een goed hart" ${ }^{194}$ De verpleegkundigen blijven, naar Duits voorbeeld, op de personeelslijst van de inrichting, zodat zij daar weer naar terug kunnen indien nodig.

Ze zitten bepaald niet stil, de verpleegkundigen. In 1926 worden in Rotterdam 1.633 huisbezoeken afgelegd, in 1927 zijn het er 3.015 door twee verpleegkundigen. ${ }^{195}$ Vier verpleegkundigen met een volledige aanstelling leggen in 19319.877 bezoeken af. ${ }^{196}$ De Gemeentelijke Geneeskundige \& Gezondheids Dienst in Breda stelt in 1932 een verpleegster-huisbezoekster aan bij het consultatiebureau voor zenuw- en zielszieken die volgens de psychiater-leider van het nazorgbureau van grote waarde is voor het geven van leiding aan het gezin. In de eerste helft van 1934 brengt zij ruim 100 nazorgbezoeken en bijna 60 voorzorgbezoeken. Voor de laatste activiteit gaat ze regelmatig op dienstbezoek bij kerken, liefdadigheidsverenigingen,

\footnotetext{
192 Beijerman, W. (1928). Verzorging van geestes- en zielszieken in de maatschappij: handleiding in het bijzonder voor wijkverplegenden. Groningen; Den Haag: J.B. Wolters, 33.

${ }^{193}$ Grinten, T.E.D. van der. De vorming van de ambulante geestelijke gezondheidszorg: een historisch beleidsonderzoek, 45.

${ }^{194}$ Overbosch, J. (1928). De nazorg van geesteszieken door het gesticht in het grootestadsmilieu. Psychiatrische en Neurologische Bladen, 32(bijblad Neurotherapie), 17-25, 19.

195 Pameijer, J.H. (1928). Plaatsing in de maatschappij van geestelijk onvolwaardigen. Verhandeling Vereeniging inzake Arbeid van Onvolwaardige Arbeidskrachten, 32, 3-15, 12.

${ }^{196}$ Pameijer, J.H. (1932). Over voor- en nazorg voor geestesziekten. Inleiding voor het $37^{\mathrm{e}}$ Gezondheidscongres te Amsterdam op 8 en 9 Juli 1932, 198-224, 201, 208.
} 
crisiscomité's en armbesturen. ${ }^{197}$ Bij de nazorgdienst in Delft wordt in 1933 een wijkverpleegkundige, opgeleid in het Sint Joris Gasthuis uit die plaats en betaald door het Zuid-Hollandse Groene Kruis, aangesteld. ${ }^{198}$ In Amsterdam schakelt Querido in 1934 twee "sociaalpsychiatrisch werksters" in, die in dat jaar samen 1.791 huisbezoeken afleggen. In 1939 legt een onbekend aantal verpleegkundigen 6.201 bezoeken af. ${ }^{199}$

Er wordt een enkele keer discussie gevoerd over rol en taken van de wijkverpleegkundige in de zorg voor psychiatrische patiënten. Tijdens een conferentie van het Antonia Wilhelmina Fonds in 1932 zegt zuster Schutte, voorzitster van de Neederlandsche Bond van Wijkverpleegsters: "De wijkverpleegster hoeft niet een volledig zenuwverpleegster te worden... Zij moet leiding kunnen geven aan den patiënt en aan het gezin. Dit gezin heeft een moeilijke taak en is meestal in het geheel niet deskundig...". ${ }^{200}$ Ze is van mening dat het feit dat er nog niet veel van de thuiszorg voor psychiatrische patiënten is terecht gekomen, niet veroorzaakt wordt door kennisgebrek van de wijkverpleegkundigen, maar door het feit "dat de huisartsen vaak een te weinig ontwikkelde 'sociaalhygiënische knobbel' hebben... Naar ik uit zeer betrouwbare bron heb vernomen, gevoelen zelfs de meeste psychiaters niets voor dit sociale werk" ${ }^{201}$ Veeger, inspecteur voor de volksgezondheid, meent dat de taak van de wijkverpleegkundige in het sociaal-hygiënische werk vooral moet zijn gericht op het gezin "waar zij als vertrouwde van de moeder en hulp van den huisdokter met haar gaven van geest en hart een der gewichtigsten posten bezet op hygiënisch, sociaal en cultureel gebied". ${ }^{202}$ De wijkverpleegkundige moet in Veeger's optiek functioneren in samenwerking met de aan de consultatiebureaus toegevoegde districtshuisbezoeksters. ${ }^{203}$

Van de verpleegkundigen zelf wordt verder niets meer vernomen. Het zijn medici die het gesprek bepalen. Zij pleiten voor nazorgverpleegkundigen die behalve de diploma's A en B een cursus voor maatschappelijk georiënteerde psychiatrie volgen. ${ }^{204}$ Tot de taken behoren voorbeeldgedrag, voorlichting, controle, milieuonderzoek ten behoeve van de nazorgarts, het zoeken van een geëigende omgeving voor

\footnotetext{
197 Willemsen, C. (2001). De belofte van het hiernumaals: zeventig jaar ambulante geestelijke gezondheidsorg in het gewest Breda 1929-1999. Nijmegen: SUN, 35.

${ }^{198}$ Grinten, T.E.D. van der. De vorming van de ambulante geestelijke gezondheidszorg: een historisch beleidsonderzoek, 55 .

199 Hart de Ruyter, Th. (1950). De afdeling Geestelijke Hygiëne. Tijdschrift voor Sociale Geneeskunde, 28, 538-550, 542.

${ }^{200}$ Antonia Wilhelmina Fonds (1932). Zesde conferentie door den Raad van Bestuur van het Antonia Wilhelmina Fonds. Utrecht, 4.

${ }^{201}$ Ibidem, 5.

${ }^{202}$ Veeger, L. (1933). Geestelijke gezondheidszorg en de wijkverpleegster-huisbezoekster. Katholieke Gezondheidszorg, 4, 158-161, 159.

${ }^{203}$ Het zijn deze districtshuisbezoeksters die vanaf de tweede helft van de jaren dertig gaan fungeren als nazorgverpleegkundigen.

${ }^{204}$ Bouman, H. (1932). Eventuele taak van Het Groene Kruis in de organisatie van de geestelijke volksgezondheid. Het Groene en Witte Kruis, 28, 226-237, 235.
} 
de patiënt, belangenbehartiging bij instanties, het assisteren bij het nazorgspreekuur en het technisch goed uitvoeren van transporten. ${ }^{205}$

\subsubsection{De opleiding B-nazorg}

Die cursus voor maatschappelijk georiënteerde psychiatrie wordt vanaf 1937 aangeboden. In dat jaar begint onder verantwoordelijkheid van de Nederlandse Vereniging voor Psychiatrie en Neurologie (NVPN) een op voor- en nazorg gerichte nascholingscursus ten behoeve van de psychiatrisch verpleegkundigen, de Voortgezette Opleiding Gediplomeerden B, ook wel de B-nazorgcursus genoemd. De NVPN werkt daartoe samen met de Algemene Nederlandse Vereniging Het Groene Kruis.

In het jaar 1941 komen de volgende thema's aan de orde: bouw van het karakter en de neurotische levenshouding, verpleging en poliklinische behandeling van neurologische patiënten, het normale en achterlijke kind, de geesteszieke in de maatschappij en de leidinggevende zuster. De cursisten lopen een stage van vier tot zes weken bij een psychiatrische voor- en nazorgdienst, en, indien ze niet over een wijkaantekening beschikken, een stage van zes maanden in de wijk, een maand op een zuigelingenconsultatiebureau, een maand op een consultatiebureau voor tuberculosebestrijding en drie weken bij een schoolarts. ${ }^{206}$ Blijkbaar wordt het praktische deel van de opleiding belangrijker gevonden dan het theoretische.

Binnen dat praktische deel bestaat veel aandacht voor niet-psychiatrische thema's. Daar doet de invloed van de psychiaters op de opleiding niet aan af. Zoals in het vorige hoofdstuk is betoogd, hebben die psychiaters ook niet veel in handen. Er bestaat geen 'sociaalpsychiatrisch instrumentarium'. En, zoals de B-opleiding lange tijd een soort afgietsel is van de A, is de opleiding B-nazorg lange tijd een aftreksel van de opleiding tot wijkverpleegkundige. Voor de werkzaamheden van de nazorgverpleegkundigen is dat blijkbaar voldoende. Die bestaan onder meer uit "adviezen aan ouders bij de opvoeding van achterlijke of abnormale kinderen; raad en hulp voor het verkrijgen van buitengewoon lager onderwijs,... tegemoetkoming in de kosten van gezinsverpleging voor geestelijk abnormalen, voorlichting aan huisarts of overheid in de kwestie of voor een patiënt internering noodzakelijk is, of zoo mogelijk het aangeven van andere wegen ter behoorlijke verpleging; raad en hulp bij het zoeken van passende arbeid voor geestelijk onvolwaardigen; adviezen aan armbesturen, gemeentelijke geneeskundige diensten, schoolbesturen, sociale vereenigingen, zoo vaak ze te doen hebben of menen te doen te hebben met psychisch abnormalen, een en ander natuurlijk voor on- en minvermogenden" ${ }^{207}$ Het is de vraag of

\footnotetext{
${ }^{205}$ Piebenga, P.J. (1934). Op welke wijze kunnen de Kruisvereenigingen meewerken bij de voor- en nazorg van geesteszieken? Het Groene en Witte Kruis, 30, 172-187, 183.

Met transporten wordt bedoeld het vervoer van patiënten bij opname in een inrichting.

${ }^{206}$ Commissie voor de Voortgezette Opleiding van Gediplomeerden B (1941). Vierde jaarverslag over 1941. Psychiatrische en Neurologische Bladen, 6, 1-2, 1/2.

${ }^{207}$ Willemsen, C. De belofte van het hiernumaals: zeventig jaar ambulante psychiatrie in het gewest Breda 1929-1999, 31.
} 
de verpleegkundigen, indien daartoe al opgeleid, gelet op de grote aantallen bezoeken aan patiënten en instanties en hun aandeel in het draaien van de consultatiebureaus, wel de tijd zouden hebben om diepgaander interventies te plegen.

Uit het verslag van de commissie Voortgezette Opleiding Gediplomeerden B over 1942 blijkt dat tot dan toe in totaal 49 verpleegkundigen de opleiding hebben afgerond. Daarvan hebben er 43 een psychiatrisch-verpleegkundige achtergrond en zes de wijkaantekening. ${ }^{208}$

\subsection{Maatschappelijk werkenden in de psychiatrie in Nederland}

Anders dan in de Verenigde Staten doen de maatschappelijk werkenden in Nederland pas vanaf het eind van de jaren twintig hun intrede in het psychiatrische werkveld. Zij beperken zich tot hulp bij het verkrijgen van werk, materiële steun, een betere woning, plaatsing van kinderen in een tehuis enzovoorts. "Met de psychologische factoren bemoeien zij zich niet. Hun functie ten opzichte van de psychiater was een ondergeschikte en uitvoerende". ${ }^{209}$ Het social casework is aan Nederlandse opleidingen voor maatschappelijk werk vóór de Tweede Wereldoorlog onbekend.

In 1928 wordt in Amsterdam het eerste Medisch Opvoedkundig Bureau (MOB) opgericht naar het voorbeeld van de Child Guidance Clinics in de Verenigde Staten. Naast psychiaters en kinderartsen zijn daar ook maatschappelijk werkenden in dienst. De laatsten hebben aanvankelijk een strikt maatschappelijk werk-taak en houden zich onder andere bezig met verbetering van de woonomgeving, geldelijke ondersteuning en uithuisplaatsing. Zij werken op aanwijzing van de psychiater. Hun taken worden al snel uitgebreid. Zij gaan, volgens Lekkerkerker, de behandeling door de psychiater mee helpen uitvoeren "via een simultane begeleiding en beïnvloeding van de ouders, die echter wel voornamelijk voorlichtend van aard was; ze mochten echter niet duidend optreden". ${ }^{210}$ Ze doen spreekuur, nemen anamneses af, winnen inlichtingen in bij derden en voeren in enkele gevallen psychologische testen uit.

In navolging van wat er in de Verenigde Staten al eerder is gebeurd, worden er in Nederland hogere eisen gesteld aan de opleiding van de maatschappelijk werkenden dan aan die van de verpleegkundigen. Er dient meer aandacht te zijn voor psychologie en psychiatrie. Vanaf 1930 gaan maatschappelijk werkenden in London een cursus Mental Health volgen. De cursus is opgezet naar Amerikaans voorbeeld. Het praktijkgedeelte vindt plaats bij Medisch-Opvoedkundige Bureau's en aan socia-

\footnotetext{
${ }^{208}$ R.K. Vereeniging Het Limburgsche Groene Kruis (1942). Jaarverslag 1942. [S.I.]: R.K. Vereeniging Het Limburgsche Groene Kruis.

${ }^{209}$ Grinten, T.E.D. van der. De vorming van de geestelijke gezondheidszorg: een historisch beleidsonderzoek, 64

${ }^{210}$ Schuurman, K. (1977). De ontwikkeling en de invloed van het beroep van psychiatrisch-sociaal werker 1928-1965. Doctoraalscriptie Sociologie, Universiteit van Amsterdam. Amsterdam: Universiteit van Amsterdam, 8.
} 
le afdelingen van psychiatrische ziekenhuizen. In de opleiding wordt onder meer aandacht besteed aan casework. Daarin ligt de nadruk op de psychologische problemen van de patiënt. Cursisten wordt geleerd niet zozeer te handelen, maar te begrijpen, mee te denken en inzicht te geven. Maar al te vaak is gebleken dat enkel het bieden van materiële hulp niets oplevert omdat er geen inzicht is ontstaan. ${ }^{211}$ In de opleiding wordt ook aandacht besteed aan de houding van de hulpverlener en aan de invloed daarvan op de patiënt. In 1938 begint de Nederlandse Federatie van Medisch Opvoedkundige Bureaus een eigen opleiding tot psychiatrisch-sociaal werkende.

Anders dan in de Verenigde Staten krijgen de psychiatrisch-sociaal werkenden, op een uitzondering na, in Nederland geen rol in de voor- en nazorg van psychiatrische patiënten. ${ }^{212}$

\subsection{Conclusies en discussie}

Aan het begin van de twintigste eeuw ontstaat de beweging van de sociale psychiatrie. Bij psychiaters, die tot dan toe overwegend klinisch georiënteerd zijn, groeit de opvatting dat niet enkel hersen-organische afwijkingen de oorzaak zijn van psychiatrische problemen. Ook de sociale omgeving wordt geacht van invloed te zijn op het ontstaan en het in stand houden daarvan en daardoor op haar beurt weer te worden beïnvloed. Om zicht te krijgen op die wederzijdse beïnvloeding en daarin te kunnen interveniëren, schakelen de psychiaters assistentie in. In de Verenigde Staten betrekken ze maatschappelijk werkenden bij hun activiteiten, in Duitsland inrichtingsverpleegkundigen en een enkele maatschappelijk werkende, in Nederland inrichtings- en wijkverpleegkundigen. Daarmee ontstaan twee nieuwe beroepsgroepen: het psychiatrisch-sociaal werk en de sociaalpsychiatrische verpleegkunde.

De psychiatrie in de Verenigde Staten kan worden omschreven als pragmatisch en gericht op resultaat. Dat kan worden verklaard tegen de achtergrond van de "vermaatschappelijking van het meer cognitieve aspect van 's mensen oriëntatie... die tot uitdrukking is gekomen in de ontwikkeling van de wetenschap... Wetenschap, en zeker sociale wetenschap, is daar vanouds gericht geweest op het oplossen van maatschappelijke problemen". 213

De Verenigde Staten kennen, met name aan de oostkust waar de sociale psychiatrie zich vooral ontwikkelt, grote problemen, veroorzaakt door onder meer immigratie en daarmee samenhangende urbanisatie. Het begrip "melting pot" is daarvan een goede karakterisering. Psychiaters komen met de gevolgen van die problemen in aanraking en zoeken oplossingen. Ook het maatschappelijk werk richt zich

\footnotetext{
211 Ibidem, 9.

212 Ibidem, 10.

${ }^{213}$ Adriaansens, H.P.M. \& Zijderveld, A.C. (1981). Vrijwillig initiatief en de verzorgingsstaat: cultuursociologische analyse van een beleidsprobleem. Deventer: Van Loghum Slaterus, 69.
} 
op die problemen, komt daardoor in aanraking met psychiatrische patiënten en zet zich daarvoor herkenbaar in. Maatschappelijk werkenden proberen om door middel van het aanpassen van de patiënten aan de omgeving of door het beïnvloeden van omgevingsfactoren de mensen zo goed en zo kwaad als het kan in de samenleving te laten functioneren. De psychiaters vinden in het maatschappelijk werk een bijna natuurlijke bondgenoot.

Een andere factor van belang is de toenemende vraag om hulp van veteranen uit de Eerste Wereldoorlog. Voorheen gezonde mannen komen uit de oorlog met problemen. Dat versterkt de opvatting dat het ontstaan van psychiatrische problemen door omgevingsfactoren, in elk geval niet enkel door aandoeningen aan het zenuwstelsel, worden veroorzaakt dan wel worden beïnvloed. Ook dit is een reden om maatschappelijk werkenden te betrekken bij de hulpverlening. Zij hebben een eigen opleiding, met het social case work een hulpverleningsmethodiek en daarmee iets te bieden. Hebben ze zich tot dan toe gericht op problemen die als sociale problemen zijn gedefinieerd, nu gaan ze zich richten op problemen die als sociaalpsychiatrische problemen worden aangeduid. Daarmee betreden ze het terrein van de psychiaters. Ze leveren een deel van hun zelfstandigheid in; hun activiteiten gaan in dienst van de psychiatrie staan.

Met de psychologisering van psychiatrisch-sociaal werk verwijderen de psychiatrisch-sociaal werkenden zich vervolgens van hun oorspronkelijke aandachtsgebied. De nadruk ligt niet langer op de relatie tussen problemen en levensomstandigheden, maar ook op de relatie tussen problemen en de persoonlijkheid van de patiënt. De aandacht richt zich onder invloed van de Mental Hygiene beweging meer dan voorheen op de preventie van problemen. Er komen andere doelgroepen in het vizier, waaronder jongeren en hun opvoeders in de Child Guidance Clinics, scholieren en delinquenten. Dat de psycho-analytische benaderingswijze bij psychiatrische patiënten bij wie sprake is van ernstige vaak chronische psychopathologie, weinig succesvol is, kan mede als verklaring worden gezien voor het feit dat veel psychiatrischsociaal werkenden zich op nieuwe cliëntgroepen gaan richten.

Op het Europese vasteland is de wetenschap, en daarmee de psychiatrie, veel minder gericht op het oplossen van maatschappelijke problemen. Die problemen zijn wat betreft omvang en urgentie minder groot dan in de Verenigde Staten. Er is in de wetenschap, anders dan in de Verenigde Staten, "een veel hardnekkiger restant aan 'idle curiosity' een rol blijven spelen". ${ }^{214}$ Anders gezegd: het denken over psychiatrische problemen en het oplossen ervan is in Duitsland en Nederland eerder filosoferend en theoretiserend. De sociale psychiatrie is er, meer dan in de Verenigde Staten, een voortzetting van de klinische psychiatrie en daarmee custodiaal en controlerend van aard. De beweging van de Mental Hygiene komt in Duitsland nauwelijks en in Nederland aarzelend op gang. Het maatschappelijk werk bestaat er wel, maar heeft zich minder herkenbaar dan in de Verenigde Staten, ingezet voor

${ }^{214}$ Ibidem, 70. 
psychiatrische patiënten. De beroepseigen methodiek, het social case work, wordt in Nederland pas na de Tweede Wereldoorlog onderdeel van de opleiding maatschappelijk werk. Het kleine aantal maatschappelijk werkenden dat zich in het buitenland schoolt, vindt vanaf begin jaren dertig als psychiatrisch-sociaal werkende grotendeels emplooi in de Medisch Opvoedkundige Bureaus.

De sociale psychiatrie in Nederland richt zich vooral op het buiten de inrichting houden van patiënten. De in het vorige hoofdstuk aangehaalde opmerking van Querido dat het hem in de periode 1930-1939 is gelukt het aantal geïnterneerden en geesteszieken constant te houden, onderstreept dit. ${ }^{215}$ De psychiaters zijn niet zozeer geïnteresseerd in "change agents", maar eerst en vooral in werkers die informatie verschaffen ten behoeve van de psychiatrische diagnostiek en die een signalerende en controlerende functie hebben. Meer dan in de Verenigde Staten zijn ze op zoek naar de "ogen en oren". Verpleegkundigen zijn daarvoor geschikt. Ervaring met psychiatrische patiënten is een voorwaarde. Inrichtingsverpleegkundigen hebben die en komen dus in aanmerking. Wijkverpleegkundigen, die bij de mensen thuis komen, informatie kunnen verstrekken en controle kunnen uitoefenen, worden bijgeschoold om die informerende en controlerende functie ten behoeve van de psychiaters te kunnen uitoefenen. Beide groepen verpleegkundigen zijn laag opgeleid. Ze hebben geen kennis van en ervaring met strategieën die zijn gericht op gedragsveranderingen of op veranderingen in levensomstandigheden. Beide groepen zijn uit de aard van hun opleiding sterk doe-gericht, en dan vooral op doen vóór, niet op doen met. Het ligt voor de hand dat ze daarmee in hun omgang met de psychiatrische patiënt en diens omgeving doorgaan. Voor de inrichtingsverpleegkundigen is de grootste verandering die van werkplek. De wijkverpleegkundigen zijn er al aan gewend om extramuraal te werken. De opleiding B-nazorg, die in 1937 van start gaat, wordt met name gevolgd door B-verpleegkundigen zonder wijkaantekening en bestaat voor het grootste deel uit wat als wijkverpleegkundige inhoud kan worden getypeerd.

De concrete werkzaamheden van de verpleegkundigen zullen niet overal gelijk zijn. In steden als Rotterdam of Amsterdam, waar verschillende verpleegkundigen samenwerken met verschillende psychiaters, zal het er, ook gezien de aard van de locatie en de problemen die daarmee samenhangen, anders aan toe gaan dan op het platteland waar een verpleegkundige, al dan niet parttime, samenwerkt met een parttime psychiater. Meer dan in de steden zullen de verpleegkundigen op het platteland een eigen aanpak ontwikkelen. De invloed van de psychiaters op de concrete werkzaamheden van de verpleegkundigen als groep kan daarmee worden gerelativeerd. Het is aannemelijk dat de verpleegkundigen, eerder dan hun collega's in de inrichtingen, tot een meer of minder zelfstandige vorm van beroepsuitoefening komen.

${ }^{215}$ Heerma van Voss, A.J. (1991). Querido, een levensverhaal. Maandblad Geestelijke Volksgezondheid, 46, 722-811, 746. 


\section{Hoofdstuk 4}

\section{Vergelijkende analyse en conclusie}

\subsection{Inleiding}

In hoofdstuk 1 is als eerste onderzoeksvraag geformuleerd: hoe is in de Nederlandse gezondheidszorg een afzonderlijk domein sociale psychiatrie tot stand gekomen? Die vraag kan nu worden beantwoord. Dat gebeurt in eerste instantie aan de hand van de beschrijving van het ontstaan van de sociale psychiatrie in de Verenigde Staten, Duitsland en Nederland gezamenlijk. Daarna volgen een concretisering per land en een vergelijking van de landen onderling. Dat de ontwikkelingen in de Verenigde Staten en Duitsland worden meegenomen, kan worden verklaard uit het feit dat ze van invloed zijn op de ontwikkelingen in Nederland en dat ze verhelderend werken indien ze worden gebruikt ter vergelijking.

De vergelijking brengt een aantal verschillen aan het licht waarmee een aanzet kan worden gegeven tot het beantwoorden van de tweede vraag uit deze studie, die luidt: hoe heeft zich in het domein van de sociale psychiatrie een afzonderlijke verpleegkundige beroepsgroep kunnen ontwikkelen? De beantwoording zal gebeuren in termen van het in hoofdstuk 1 gegeven theoretische kader dat richtinggevend is voor het uitvoeren van dit onderzoek.

In de hoofdstukken hierna zal de gegeven aanzet tot beantwoording van vooral de tweede onderzoeksvraag verder worden geconcretiseerd, zodat de vraag hoe de sociaalpsychiatrische beroepsgroep zich heeft kunnen ontwikkelen, meer in detail kan worden beantwoord. Hoe dit vorm zal krijgen wordt uiteengezet aan het einde van dit hoofdstuk.

\subsection{Het ontstaan van het domein van de sociale psychiatrie}

Voordat aan het begin van de twintigste eeuw de psychiatrie zich extramuraal gaat ontwikkelen, is het domein ervan in de Verenigde Staten, Duitsland en Nederland voornamelijk beperkt tot inrichtingen. Vanaf het midden van de negentiende eeuw zijn die inrichtingen in aantal en in omvang fors gegroeid. De groei wordt enerzijds veroorzaakt door een grote stijging van het aantal opnames, anderzijds door het feit dat de behandeling van de patiënten nauwelijks effectief is. Grote groepen mensen, waaronder verstandelijk gehandicapten, dementen, psychotici, onmaatschappelijken en zeer zorgintensieve patiënten met dementia paralytica, verblijven in overvolle afdelingen waar de hygiëne te wensen overlaat. Agressie, dwang en drang zijn aan de orde van de dag. 
In dat intramurale psychiatrische domein zijn twee beroepsgroepen actief bij de behandeling en de verzorging van patiënten. De ene groep bestaat uit artsen, al dan niet opgeleid tot zenuwarts of psychiater. De andere groep bestaat uit voorlopers van wat nu verpleegkundigen zijn: zaalknechten en zaalmeiden. In de Verenigde Staten heten ze attendants en orderlies. De laatsten zijn mannen die niet worden betrokken in de behandeling van de patiënten. De omschrijving van deze functie kan worden beschouwd als een eufemisme voor het vaak met geweld beteugelen van onrust en agressie.

Het aanzien van beide beroepsgroepen is laag en hun kennisgebieden zijn nauwelijks tot niet ontwikkeld. De oorzaken van psychiatrische ziekten worden verondersteld hersenorganisch te zijn, maar daarmee houdt het meestal op. De psychiaters komen veelal niet verder dan het stellen van diagnoses. Lichamelijke aandoeningen, samengaand met bijvoorbeeld ouderdom en de al genoemde dementia paralytica, maar ook als gevolg van onhygiënische omstandigheden hebben tot gevolg dat het werk van de psychiaters overwegend somatisch van aard is. Ze hebben de zorg voor veel, vaak honderden patiënten per arts.

De zaalknechten en -meiden zijn niet of laag geschoold en kunnen vaak niet lezen en schrijven. Beroepsopleidingen komen pas aan het einde van de eeuw op initiatief van de psychiaters tot stand. De inhoud ervan, bepaald door de psychiaters, is in hoge mate somatisch georiënteerd en gericht op het aandragen van informatie ten behoeve van de psychiatrische diagnostiek. De mogelijkheid tot scholing maakt het beroep er blijkbaar niet veel aantrekkelijker op, want het aantal gediplomeerden groeit maar langzaam. Het verpleegkundige werk bestaat, in het verlengde van het werk van de psychiaters, voor het grootste deel uit somatisch-verzorgende en huishoudelijke activiteiten en, niet te vergeten, uit het handhaven van rust en orde.

Aan het begin van de twintigste eeuw gaat de psychiatrie haar domein uitbreiden, over de muren van de inrichtingen heen. Het is een combinatie van factoren, herkenbaar in zowel de Verenigde Staten als in Duitsland en Nederland, die de aanzet vormt om het aandachtsgebied van de psychiatrie te verbreden tot activiteiten buiten de inrichting. Industrialisatie, urbanisatie en migratie hebben een maatschappelijke dynamiek tot gevolg die volgens velen tot sociale ontwrichting leidt en tot een grote mate van bezorgdheid daarover. Dat vraagt om ingrijpen. Inzichten uit de sociologie en de psychologie maken dat menselijk gedrag niet enkel meer als biologisch gedetermineerd kan worden gezien, maar dat factoren in de omgeving worden geacht bij te dragen aan het ontstaan en het in stand houden van gedragsproblemen. Die factoren dienen bij het voorkomen en oplossen ervan te worden meegenomen. De weinig succesvolle intramurale psychiatrie, de nauwelijks nog hanteerbare situatie in de inrichtingen en de sterk stijgende kosten die gepaard gaan met hospitalisatie van grote groepen mensen zijn aanleiding om op zoek te gaan naar extramurale alternatieven. Er zijn, kort samengevat, meer of minder 
dwingende redenen om tot het verleggen van de aandacht over te gaan én er zijn nieuwe perspectieven om daaraan invulling te geven.

Voor de psychiatrie ontstaan zo twee nieuwe opties. De ene optie is de mogelijkheid om bij te dragen aan de preventie van gedragsproblemen en vroegtijdige interventie. Daarop zal vanaf omstreeks het midden van de jaren twintig de beweging van de psychohygiëne zich gaan richten. De andere optie is de mogelijkheid tot het oplossen of verkleinen van al bestaande problemen, te weten de nauwelijks succesvolle behandeling van grote groepen patiënten in overvolle inrichtingen en de daarmee gepaard gaande kosten én het voorbereiden op ontslag. Dat laatste wordt het aandachtsgebied van de sociale psychiatrie. Naast de beweging van de psychohygiëne en de sociale psychiatrie blijft de inrichtingspsychiatrie bestaan. Er ontstaat een driedeling in de wereld van de geestelijke gezondheidszorg.

De sociale psychiatrie, niet de psychohygiëne, is het nieuwe domein waarop de verpleegkundigen die later sociaalpsychiatrisch verpleegkundigen zullen worden genoemd, actief worden. Daarmee is de reden gegeven waarom de beweging van de psychohygiëne in de volgende hoofdstukken verder buiten beschouwing blijft.

\subsubsection{De Verenigde Staten}

In de Verenigde Staten, met name in de snel groeiende steden, zijn werkloosheid, armoede, afwijkend gedrag, criminaliteit, immigratie en daaraan gerelateerde vraagstukken van multiculturele aard tot moeilijk beheersbare problemen geworden. Ze hebben veel invloed op allerlei facetten van de samenleving en van het leven van individuen, waaronder de psychische en de lichamelijke gezondheid. Bij medici in ziekenhuizen en psychiatrische inrichtingen groeit aan het begin van de eeuw het besef dat het enkel symptomatisch behandelen van gezondheidsproblemen niet langer voldoet. Zij schakelen maatschappelijk werkenden in om informatie te verzamelen over sociale factoren, die kan worden gebruikt bij de medische diagnostiek. Tegelijkertijd moet beïnvloeding van die factoren door de maatschappelijk werkenden ertoe leiden dat de gezondheidsproblemen effectiever kunnen worden aangepakt. Het zorgen voor geschikte huisvesting is er een voorbeeld van.

De overheid, al dan niet daartoe gestimuleerd door psychiaters, draagt door wetgeving vanaf $1906 \mathrm{bij}$ aan het betrekken van maatschappelijk werkenden bij nazorgcomités, verbonden aan de state mental hospitals.

Belangrijk ook zijn de activiteiten van het National Committee for Mental Hygiene vanaf 1909, met aanvankelijk als doel het hervormen van de inrichtingspsychiatrie. Die activiteiten, mede mogelijk gemaakt door financiële ondersteuning van particulieren, zijn vooral gericht op het beïnvloeden van de publieke opinie. In de loop van de daarop volgende jaren gaat de beweging van de psychische hygiëne zich op andere gebieden richten, zoals de zorg voor verstandelijk gehandicapten, het gevangeniswezen, de jeugdzorg en de zorg voor veteranen van de Eerste Wereldoorlog. De "freudianisering" van de Amerikaanse psychiatrie gedurende de jaren 
twintig geeft een nieuwe impuls aan de beweging van de mental hygiëne die zich steeds meer gaat richten op preventie en vroegtijdig interveniëren.

Maatschappelijk werkenden zijn al vanaf het eind van de negentiende eeuw actief in de zorg voor psychiatrische patiënten en zijn dus geen nieuwkomers in de geestelijke gezondheidszorg. Ze ontwikkelen vanaf het begin van de twintigste eeuw eigen opleidingen en in de loop van het tweede decennium een eigen methodiek. Die is gericht op het tot stand brengen van inzicht in de problemen en vervolgens op verandering of aanpassing. Dezelfde methodiek maakt het ook mogelijk om gericht informatie te verzamelen ten behoeve van de psychiaters.

Samen met de psychiaters ontwikkelen de maatschappelijk werkenden in 1918 een nieuwe opleiding. Deze opleiding komt niet toevallig juist dan tot stand. Er is vraag naar geschoolde krachten die ingezet kunnen worden ten behoeve van de militairen die psychische problemen hebben na hun ervaringen aan het front van de Eerste Wereldoorlog in Europa.

Het begin van de opleiding is een markeringspunt in het ontstaan van het vooralsnog kleine specialisme psychiatrisch-sociaal werk. Er worden vervolgens leerboeken geschreven, een beroepsvereniging opgericht en opleidingen ingericht aan colleges en universiteiten. Door de samenwerking met de psychiaters verliest het maatschappelijk werk weliswaar gedeeltelijk zijn eigenstandigheid, maar krijgt het de kans om aan het social casework invulling te geven. Deze invulling heeft aanvankelijk een sociale oriëntatie die in de loop van de jaren twintig verschuift naar een meer psychologische/psychodynamische oriëntatie. Ook al blijft het voor de psychiatrisch-sociaal werkenden moeilijk om hun eigen activiteiten duidelijk af te bakenen, in de praktijk van alledag lijkt dat weinig problematisch. Zij vervullen een rol die de psychiaters niet in staat zijn te vervullen omdat de laatsten dat getalsmatig niet waar kunnen maken en omdat ze er niet voor zijn opgeleid.

Als de psychiatrisch-sociaal werkenden met een overwegend psychodynamische oriëntatie te ver af komen te staan van de meer sociaalpsychiatrische nazorgpraktijk, is er ruimte om elders emplooi te vinden, bijvoorbeeld in de child guidance clinics. Met de voortgaande professionalisering wendt de beroepsgroep zich voor een deel af van zijn oorspronkelijke doelgroep, te weten opgenomen en ontslagen psychiatrische patiënten.

\subsubsection{Duitsland}

De aanzetten tot extramurale psychiatrische zorg in Duitsland vanaf omstreeks 1910 door grotere steden en psychiatrische inrichtingen, worden door de Eerste Wereldoorlog onderbroken. Na de oorlog wordt, onder moeilijke economische en maatschappelijke omstandigheden, de draad weer opgepakt. Er worden met name vanuit nauwelijks nog functionerende inrichtingen nazorgactiviteiten georganiseerd aan ontslagen patiënten, vooral in de vorm van huisbezoeken. Deze zorg is in hoge mate 
inrichtingsvervangend en daarmee structurerend en controlerend van aard. Ze wordt met name gerealiseerd door inrichtingsverpleegkundigen die laag zijn opgeleid, in elk geval niet gericht op sociaalpsychiatrische of maatschappelijke zorgverlening. In hun opvattingen en werkwijzen worden ze sterk gestuurd door de psychiaters. Hetzelfde kan worden gezegd van de maatschappelijk werkenden die worden ingezet in steden, na minimale psychiatrische scholing.

Ontwikkelingen op het gebied van de geestelijke volksgezondheid, zoals die zich voordoen in de Verenigde Staten blijven bij de psychiaters in Duitsland niet onopgemerkt, zoals blijkt uit publicaties in vaktijdschriften. Ze worden echter door de al eerder genoemde behoudende oriëntatie van de psychiatrie, waarschijnlijk ook door de algehele malaise na de Eerste Wereldoorlog en door de maatschappelijke ontwikkelingen die zich vanaf het begin van de jaren dertig voltrekken, onmogelijk gemaakt. Het betrekken van ontwikkelingen en gebeurtenissen in Duitsland in deze studie is daarmee niet meer langer zinvol.

\subsubsection{Nederland}

De sociale psychiatrie in Nederland ontstaat met name vanuit de grootstedelijke problematiek, aanvankelijk uitgaande van gemeentelijk en particulier initiatief. In beide initiatieven speelt de psychiater Meijers een grote rol. Hij begint in 1917 in Amsterdam het Consultatiebureau voor Zenuw- en Zielszieken en betrekt daar een verpleegkundige bij.

De door Meijers in 1924 opgerichte Centrale Vereeniging ter Behartiging van de Maatschappelijke Belangen van Zenuw- en Zielszieken richt binnen enkele jaren zestien consultatiebureaus in. Psychiaters en wijkverpleegkundigen zijn erin werkzaam. Voor de verpleegkundigen wordt door de vereniging beperkt psychiatrische scholing georganiseerd. Aan hen wordt, naast assistentie van de psychiater op het consultatiebureau, een rol toebedacht in het vroegtijdig opsporen van psychiatrische problematiek. Daarmee is de sociale psychiatrie aanvankelijk voor een deel, althans in aanzet, gericht op preventie.

De start van de buitendienst aan Maasoord in Rotterdam in 1926 luidt een belangrijke verandering in. Aan de inrichting verbonden psychiaters en verpleegkundigen houden consultatiebureau en leggen veel huisbezoeken af bij ontslagen patiënten. Het aantal verpleegkundigen is klein, het aantal psychiaters eveneens. De dienst draagt bij aan besparing in de opnamekosten. Het succes wordt daaraan voor een groot deel afgemeten. Andere inrichtingen volgen het voorbeeld van Maasoord. De werkzaamheden van de buitendiensten hebben grotendeels het karakter van nazorg en kunnen als structurerend en controlerend worden aangemerkt.

Bij de afdeling voor Geestes- en Zenuwziekten van de Amsterdamse Gemeentelijke Geneeskundige \& Gezondheids Dienst zijn het ook psychiaters en verpleegkundigen die met ingang van 1934 het werk doen, waarbij de grote aantallen huisbezoeken die de verpleegkundigen afleggen weer in het oog springen. Het voorkómen 
van opnames, voorzorg genoemd, maakt onderdeel uit van de activiteiten. Desondanks heeft het werk in hoge mate het karakter van maatschappelijke dienstverlening, waarvan structurering en controle belangrijke onderdelen zijn, met als doel het aantal psychiatrische opnames te verminderen, in elk geval niet te laten toenemen. Dat gebeurt met succes. In andere steden worden eveneens gemeentelijke nazorgdiensten opgezet.

In de jaren tot 1940 ontwikkelt zich in Nederland het sociaalpsychiatrische domein, uitgaande van het particulier initiatief, inrichtingen, gemeentelijke en provinciale diensten en kruisverenigingen. De activiteiten die op dat domein worden ontplooid zijn met name gericht op de nazorg aan psychiatrische patiënten. In steden zoals Rotterdam en Amsterdam is de urgentie van nazorg duidelijk. Het organiseren ervan is relatief gemakkelijk doordat het centraal kan gebeuren. Eenmaal geëffectueerd zijn de resultaten merkbaar. Buiten de steden is het belang van nazorg minder herkenbaar. Voor zover dat belang wordt onderkend, bemoeilijkt en vertraagt het ontbreken van centrale regie het opzetten van functionerende nazorgdiensten. Daar waar de diensten tot stand komen is weinig menskracht beschikbaar voor geografisch relatief grote verzorgingsgebieden. Een landelijke dekking, zoals in de thuiszorg het geval is, is tegen het begin van de Tweede Wereldoorlog dan ook nog niet gerealiseerd.

In het domein zijn twee beroepsgroepen, te weten verpleegkundigen en psychiaters, prominent aanwezig. De psychiaters leiden de diensten, houden consultatiebureau, verwijzen patiënten en doen, in beperkte mate, huisbezoeken. De verpleegkundigen assisteren bij de spreekuren en leggen grote aantallen huisbezoeken af. Die bezoeken zijn vooral bedoeld om informatie te verzamelen ten behoeve van de psychiater, om te bekijken hoe het gaat met de patiënt, om te instrueren en te controleren en om patiënten te bewegen het spreekuur te bezoeken.

Ofschoon, in de steden duidelijker merkbaar dan daarbuiten, met name door de kostenbesparing de nazorg de wind in de zeilen krijgt, kan de betekenis van het idealisme van voorlopers zoals Meijers, Pameijer en Querido niet onvermeld blijven.

Sociaalpsychiatrisch geschoold zijn zowel de psychiaters als de verpleegkundigen niet. Ze functioneren op basis van persoonlijk inzicht en opgedane ervaringen. De psychiatrie kent geen specialisme sociale psychiatrie. De opleiding B-nazorg voor de verpleegkundigen is zeer praktijkgeoriënteerd met een nadruk op nietpsychiatrische onderwerpen. Begin jaren veertig zijn er 49 gediplomeerden afgeleverd waarvan er zes een wijkaantekening hebben. De klinische oriëntatie van de verpleegkundigen is nog sterk.

\subsection{Analyse en conclusie}

Het zijn psychiaters, voor zover ze onder die naam al bestaan, die, tegen de achtergrond van globaal gesproken overeenkomstige maatschappelijke en beroepsinhou- 
delijke vraagstukken en ontwikkelingen in de drie landen, initiatieven nemen die leiden tot zorgverlening buiten de muren van de inrichtingen. Daarmee ontstaat een nieuw, in omvang beperkt domein in de gezondheidszorg, de sociale psychiatrie. Zo bezien is het, met andere woorden, een samengaan van meta- en intraprofessionele factoren dat de aanleiding vormt tot het ontstaan van het nieuwe domein.

De psychiaters hebben weliswaar ideeën en idealen, maar ze hebben noch de vaardigheden, noch zijn ze voldoende in aantal om er handen en voeten aan te geven. De meesten verrichten de extramurale activiteiten naast hun werk in de inrichting. Dat gegeven kan worden beschouwd als een vorm van horizontale functiedifferentiatie. De psychiaters hebben in het nieuwe domein anderen nodig om mede vorm en invulling te geven aan de activiteiten. Vrijwel vanaf het begin is er dus arbeidsdeling aan de orde.

De keuzes die de psychiaters maken, kunnen worden verklaard tegen de achtergrond van verschillen die er, ondanks de overeenkomsten, bestaan tussen de Verenigde Staten enerzijds en Duitsland en Nederland anderzijds. De problemen in de Amerikaanse samenleving zijn urgenter dan op het Europese vasteland. Daar komt bij dat sociologie en psychologie meer invloed hebben op de Amerikaanse psychiatrie dan op de Duitse en de Nederlandse. Voorts is de Amerikaanse samenleving in het algemeen pragmatischer en meer probleemoplossend georiënteerd dan de Duitse en de Nederlandse. Dat alles maakt dat de Amerikaanse psychiatrie, althans de voorhoede ervan, dynamischer is dan die in Duitsland en Nederland, en de sociale omgeving niet enkel gebruikt als verklaring voor het ontstaan van psychiatrische problemen, maar ook bij het daadwerkelijke oplossen en voorkomen ervan. Het is daarom dat de Amerikaanse psychiaters kiezen voor maatschappelijk werkenden. Het gegeven dat deze laatsten zich al hebben geprofileerd, speelt bij die keuze mee. Zij beschikken over kennis en vaardigheden die de psychiaters niet hebben. De wijze waarop de arbeidsdeling in de Amerikaanse sociale psychiatrie tot stand komt en invulling krijgt, kan dus niet enkel worden verklaard door ernaar te kijken vanuit het perspectief van de psychiaters. Ze is bij nader inzien een interprofessionele aangelegenheid. Binnen de grenzen die de psychiaters aangeven, krijgen en gebruiken de maatschappelijk werkenden de ruimte om actief te zijn en hun eigen accenten te leggen. Er wordt weliswaar gediscussieerd over het invullen en over de afbakening van de activiteiten en de verantwoordelijkheden van de beide beroepsgroepen, maar het primaat van de psychiaters is daarmee niet in het geding. De psychiatrisch-sociaal werkenden verwerven een relatief eigenstandige positie en professionaliseren succesvol. Opleiding, het niveau daarvan plus een daaraan gekoppelde eigen manier van werken zijn de verklarende factoren. Met de professionalisering nemen de psychiatrisch-sociaal werkenden voor een deel afstand van het oorspronkelijke werkveld.

De psychiaters in Duitsland en Nederland zijn ten opzichte van hun Amerikaanse collega's behoudend, gericht op een extramurale psychiatrie die sterk in het ver- 
lengde ligt van de inrichtingspsychiatrie en daarmee veel meer georiënteerd op aanpassing, minder op verandering. Bezien vanuit het perspectief van de psychiaters ligt het inschakelen van verpleegkundigen net zo voor de hand als van de maatschappelijk werkenden in de Verenigde Staten. De rol die de verpleegkundigen hebben in het tot stand komen en de ontwikkeling van de arbeidsdeling is, vergeleken met die van de maatschappelijk werkenden, een weinig actieve.

De verpleegkundigen in Nederland zijn, anders dan de maatschappelijk werkenden in de Verenigde Staten, niet veel meer dan de ogen en oren, zo men wil "de verlengde arm" van de psychiaters met vooral aandacht voor structuur en controle. Dat is wat er van hen wordt gevraagd en blijkbaar doen ze dat naar tevredenheid van de psychiaters en van zichzelf. Van discussie over het invullen en afbakenen van taken en verantwoordelijkheden, zowel binnen als tussen de beroepsgroepen, is nauwelijks sprake. Voor zover die al wordt gevoerd gebeurt dat, op een enkele uitzondering na, door artsen die laten weten wat de verpleegkundigen moeten kennen en kunnen en over welke persoonskenmerken ze dienen te beschikken. Aanwijzingen voor het bundelen van ideeën van verpleegkundigen in een beroepsvereniging zijn er niet.

Vanaf 1937, met de komst van de opleiding B-nazorg, groeit langzaam het aantal nazorgverpleegkundigen met een psychiatrisch-verpleegkundige opleiding, al dan niet aangevuld met een opleiding in de somatiek. De betekenis van de wijkverpleegkundigen voor de nazorg neemt tegelijkertijd af. Daarmee is niet gezegd dat deze laatste groep in de thuiszorg niet meer in aanraking komt met nazorgpatiënten.

\subsection{Terugkoppeling naar de theorie}

In hoofdstuk 1 is de keuze voor het bestuderen van professies met behulp van Abbott's ideeën beargumenteerd. Kern van die ideeën is dat aan elkaar gerelateerde professies met elkaar interacteren rond de zeggenschap die ze claimen over wat ze doen en hoe ze dat doen. De mate van succes van het werk, van de interventies, bepaalt in hoge mate de kracht van de claim en daarmee de mate van succesvol professionaliseren. Het ontwikkelen van een abstract kennissysteem wordt van belang geacht om de claim te kunnen onderbouwen. Omdat professies die op eenzelfde domein actief zijn elkaar beïnvloeden, maar ook omdat ze deel uitmaken van een maatschappelijk krachtenveld, is het niet toereikend om ze enkel te bestuderen vanuit een intraprofessioneel perspectief. Een interprofessioneel en een metaprofessioneel perspectief dienen daaraan te worden toegevoegd.

Benson's opvattingen over interacties tussen organisaties, toegepast op interacties tussen beroepsgroepen, zijn, zoals in hoofdstuk 1 is uiteengezet, behulpzaam bij het nader analyseren van professies. Het centrale thema daarbij is consensus. Die consensus betreft de mate waarin er overeenstemming bestaat over elkaars werk- 
terrein en taken, over de visie die aan het werk ten grondslag ligt, over de mate waarin er positief wordt geoordeeld over elkaars activiteiten en over de mate waarin er afstemming bestaat van de wederzijdse activiteiten. Aangenomen wordt dat de dimensies, uitgezet op een continuüm van hoog naar laag, dicht bij elkaar in de buurt komen. Naar mate dat het geval is kan er worden gesproken van hogere of lagere interprofessionele coherentie. Eenzelfde redenering kan worden toegepast voor het vaststellen van de intraprofessionele coherentie. Hoge intraprofessionele coherentie wordt geacht voorwaarde te zijn voor succesvol professionaliseren.

Geplaatst tegen de achtergrond van Abbott en Benson's ideeën kan het volgende worden gezegd over het nieuwe domein van de sociale psychiatrie en van de twee op dat domein actieve beroepsgroepen in Nederland omstreeks 1940. Dat domein is, gezien het aantal actieve psychiaters en verpleegkundigen, in omvang beperkt en het groeit vooralsnog langzaam. De claim van de sociale psychiatrie is een overzichtelijke, namelijk het buiten de inrichting laten verblijven van psychiatrische patiënten. Die claim wordt, aanvankelijk met name in de steden, met succes overeind gehouden. De activiteiten die door de twee centrale beroepsgroepen worden ondernomen om de patiënten buiten de inrichting te houden, zijn nauwelijks operationeel omschreven. De domeinspecifieke ontwikkeling van beide groepen staat nog in de kinderschoenen.

Er bestaat geen extramuraal georiënteerde opleiding voor psychiaters en een sociaalpsychiatrische methodiek bestaat al evenmin. Vastgesteld kan worden dat er binnen de groep psychiaters overeenstemming bestaat over de opvatting dat nazorgactiviteiten, gericht op het buiten de inrichting houden van patiënten, noodzakelijk zijn. Dat is een aanwijzing voor het bestaan van ideologische consensus. Er bestaat eveneens overeenstemming over de manier waarop daaraan handen en voeten moet worden gegeven, te weten door het instellen van consultatiebureaus en het doen van huisbezoeken. Vastgesteld kan worden dat de psychiaters het er onderling over eens zijn wat hun rol is en welke die van de verpleegkundigen. Dat wijst op domeinconsensus. Gegeven de ideologische consensus en de domeinconsensus en het door Benson veronderstelde evenwicht tussen de vier dimensies kan worden aangenomen dat de psychiaters positief oordelen over elkaars werk en dat hun werkzaamheden op elkaar zijn afgestemd. Ofschoon de visie op en de inhoud van de activiteiten nog weinig zijn uitgekristalliseerd, lijkt er binnen de psychiatrische beroepsgroep een coherente kijk te bestaan op het domein en op de activiteiten van en de verhoudingen tussen de twee relevante beroepsgroepen in dat domein.

De verpleegkundigen ontwikkelen zo bezien eerder dan de psychiaters een zichtbaar eigen manier van werken, die voornamelijk bestaat uit het zelfstandig afleggen van huisbezoeken. Dat, en het gegeven dat zij, hoewel nog in kleine aantallen, vanaf 1937 instromen in een nieuwe opleiding, kan worden opgevat als een signaal van domein- en ideologische consensus in aanzet. Er bestaat, anders gezegd, 
binnen de verpleegkundige beroepsgroep, hoe weinig uitgewerkt dan ook, overeenstemming over een min of meer afgebakend werkveld waarin zij taken hebben waarvoor toegespitste scholing nodig is. Ofschoon het niveau van de nieuwe verpleegkundige scholing laag is en een eigen methodiek niet aan de orde is, kan het ontstaan van de opleiding B-nazorg worden beschouwd als een markering in de beroepsontwikkeling.

Gezien de manier waarop verpleegkundigen en psychiaters hun plaats in het domein van de sociale psychiatrie innemen en daaraan invulling geven, bestaat er overeenstemming over elkaars werkterrein en taken en over de visie van waaruit het werk wordt verricht. Dat vormt een aanwijzing voor interprofessionele domeinen ideologische consensus.

Over de mate waarin de twee beroepsgroepen tot werkcoördinatie komen, dit wil zeggen tot afstemming van de wederzijdse activiteiten, kan het volgende worden opgemerkt. De verpleegkundigen, veelal met een voltijds dienstverband, vervullen de rol die de psychiaters, meestal met deeltijdse aanstellingen, hen toekennen blijkbaar naar verwachting. De psychiaters doen consultatiebureau waarbij de verpleegkundigen assisteren. De verpleegkundigen gaan erop uit voor de huisbezoeken; de psychiaters doen dat, zeker buiten de steden, incidenteel. In de praktijk van alledag zal die afstemming op basis van de concrete situatie tot stand komen tussen individuele psychiaters en verpleegkundigen. Er zijn geen aanwijzingen dat dat tot problemen leidt. De wederzijdse activiteiten zijn op elkaar afgestemd, hetgeen een aanwijzing is voor interprofessionele werkcoördinatie. In het verlengde hiervan kan worden aangenomen dat de beide groepen positief oordelen over elkaars werk.

Samenvattend luidt de conclusie dat in Nederland omstreeks 1940 de beide beroepsgroepen in het domein van de sociale psychiatrie, zowel in termen van intraals interprofessionele coherentie, in evenwicht zijn.

\subsection{Vooruitblik}

Deze conclusie vormt het vertrekpunt van waaruit de periode van omstreeks 1940 tot omstreeks 1985 zal worden bestudeerd. Rond 1985 wordt de rust die is verstoord door de ingrijpende gevolgen van de Riagg-vorming geacht, althans enigszins, te zijn teruggekeerd. Dat bestuderen gebeurt tegen de achtergrond van maatschappelijke ontwikkelingen en van ontwikkelingen in de psychiatrie.

De tweede helft van de jaren veertig en de jaren vijftig laten een sterke groei zien van de extramurale geestelijke gezondheidszorg. Aanvankelijk gebeurt dat met name in de Medisch Opvoedkundige Bureaus en de Bureaus voor Levens- en Gezinsmoeilijkheden. Maar de nazorgfunctie van de extramurale psychiatrie groeit eveneens, mede door de komst van psychofarmaca die het ontslag van patiënten uit de inrichtingen mogelijk maken. Eerst vooral in de steden, later ook elders in het land, wordt naast nazorg de aandacht gericht op het voorkomen van opnames van 
mensen met psychiatrische problemen. In de loop van de jaren, vooral vanaf begin jaren zestig, groeien de nazorgdiensten, dan Sociaal-Psychiatrische Diensten genoemd, uit tot instellingen voor de extramurale behandeling van psychiatrische patiënten.

Onder invloed van ontwikkelingen in onder meer de psychologie en de sociologie ontstaan er nieuwe opvattingen over het ontstaan en de behandeling van psychiatrische problemen. Tussenmenselijke betrekkingen en sociale structuren worden geacht de veroorzakers van die problemen te zijn. De nadruk in de behandeling komt te liggen op het krijgen van inzicht in de problemen en op persoonlijke ontwikkeling en groei. Psychosociale en psychotherapeutische interventies worden geacht daarvoor de aangewezen methoden te zijn. Steeds meer problemen worden gedefinieerd in termen van geestelijke gezondheidsproblemen en komen bijgevolg in aanmerking voor behandeling. Daardoor zet de groei van de extramurale geestelijke gezondheidszorg in de jaren zeventig onverminderd door. De medische psychiatrie, en met name de inrichtingspsychiatrie, komt onder vuur te liggen.

Financieel wordt de uitbreiding mogelijk gemaakt door de toenemende welvaart. De Sociaal-Psychiatrische Diensten worden vanaf 1961 gedeeltelijk door de overheid gefinancierd. De intramurale psychiatrie komt vanaf 1967, de extramurale psychiatrie vanaf 1971 onder de werking van de Algemene Wet Bijzondere Ziektekosten (AWBZ).

Net zoals dat al het geval is in bijvoorbeeld de somatische thuiszorg ontstaat er landelijk een dekkend stelsel van in dit geval extramurale voorzieningen op het gebied van de geestelijke gezondheidszorg. Om de samenhang binnen dat stelsel te versterken en de toegankelijkheid ervan te verbeteren en te waarborgen ontstaan er initiatieven tot regionalisatie, waarvan het eerste in 1956 in Limburg wordt gerealiseerd, die uiteindelijk resulteren in de vorming van de Riagg's in 1982.

De beantwoording van de twee centrale vragen, namelijk hoe ontwikkelt zich het domein van de sociale psychiatrie en hoe evolueert binnen dat domein de verpleegkundige beroepsgroep, wordt in de komende hoofdstukken tegen de achtergrond van het hiervoor geschetste voortgezet.

Om de ontwikkeling van de sociaalpsychiatrische verpleegkunde helder te krijgen zullen aandachtsgebied en werkzaamheden in kaart worden gebracht. Er zal worden verhelderd vanuit welke uitgangspunten of vooronderstellingen er wordt gewerkt, door wie ze worden geformuleerd, hoe en door wie taken worden geoperationaliseerd en afgebakend. Met het beschrijven van de hiervoor genoemde onderwerpen, zowel binnen de verpleegkundige groep als in relatie tot de psychiatrische beroepsgroep, worden de inter- en intraprofessionele coherentie en de werkcoördinatie in beeld gebracht.

De inhoud van de verpleegkundige opleiding, het niveau ervan en het al dan niet ontwikkelen van methodieken komt vervolgens aan de orde. Daarmee wordt 
inzicht gegeven in de vraag of en hoe deze beroepsgroep haar kennisgebied onderbouwt en welke factoren daarop invloed hebben. Ook het zich organiseren van een beroepsgroep, de manier waarop dat gebeurt en de gevolgen daarvan voor het denken over en het uitvoeren van werkzaamheden zijn aanwijzingen voor de mate van professionalisering. Dat onderwerp zal eveneens in hoofdstuk 5 worden behandeld.

Een laatste aandachtspunt in het komende hoofdstuk is de positie van de verpleegkundigen en de psychiaters in het domein van de sociale psychiatrie. In de tot nu toe bestudeerde periode is gebleken dat zij de prominente spelers zijn. Bekeken zal worden of dat zo blijft. De mate waarin dat al dan niet het geval is kan gevolgen hebben voor hetgeen in de voorafgaande vragen aan de orde is gekomen. Anders gezegd: het intra- en het interprofessionele landschap kunnen erdoor worden gewijzigd.

In hoofdstuk 6 wordt een institutionele analyse gemaakt van de sociale psychiatrie in de provincie Limburg tot ongeveer 1975 tegen de achtergrond van ontwikkelingen in de sociale psychiatrie in Nederland. Ontstaan en verloop ervan worden geschetst en verklaard. Er wordt bekeken of er verschillen zijn met de gang van zaken elders in Nederland, en zo ja welke, en hoe die verschillen kunnen worden verklaard. Zoals zal blijken hebben de ontwikkelingen in Limburg hun eigen dynamiek en zijn ze op onderdelen specifiek. Tot halverwege de jaren vijftig komen ze in grote lijnen overeen met wat zich elders in het land eerder en sneller voltrekt. Vanaf dan komen er belangrijke veranderingen tot stand, met name op het gebied van regionalisering, die richtinggevend worden voor de organisatie van de Nederlandse sociale psychiatrie en de extramurale geestelijke gezondheidszorg in de jaren daarna.

De vraag hoe verpleegkundigen de beroepsontwikkeling hebben beleefd en hoe ze de relatie met andere beroepsgroepen in de sociale psychiatrie karakteriseren, komt aan de orde in hoofdstuk 7. Het beeld komt naar voren van concrete, geëngageerde doeners die aan de slag gaan waar dat nodig is en daarbij inventief omgaan met mensen en middelen. Gegeven de mogelijkheden die ze krijgen gebruiken ze de ruimte om naar eigen inzicht op te treden. De vorming van de Riagg's in 1982 heeft gevolgen voor het werk van de groep, voor de verhoudingen binnen de groep en voor de verhoudingen met andere beroepsgroepen in het domein van de sociale psychiatrie. De toenemende therapeutische oriëntatie en de gevolgen daarvan voor de manier waarop patiënten, vanaf dan cliënten, worden benaderd, voeren tot ingrijpende veranderingen. Volgens betrokkenen komen die lang niet altijd ten goede aan de chronisch psychiatrische patiënt.

Uit hoofdstuk 8 wordt duidelijk dat na de Riagg-vorming de rust niet terugkeert. De grenzen tussen de intra- en de extramurale geestelijke gezondheidszorg beginnen te vervagen. In dat proces speelt de overheid een belangrijke rol. Er worden aan het begin van de eenentwintigste eeuw ingrijpende stelselveranderingen aangekondigd die, indien uitgevoerd, vergaande gevolgen zullen hebben voor de tweede- 
lijns geestelijke gezondheidszorg. De sociaalpsychiatrisch verpleegkundigen blijken sterk te worden beïnvloed door ontwikkelingen en gebeurtenissen van buitenaf. Zo verliezen ze hun monopoliepositie in het domein van de extramurale geestelijke gezondheidszorg en wordt de eigen beroeopsopleiding opgeheven. De verpleegkundigen, althans een spraakmakend deel ervan, nemen voor het eerst merkbaar stelling in het domeindebat en kiezen voor de moeilijk benaderbare psychiatrische patiënt en voor wat ze noemen het sociaalpsychiatrische gedachtegoed.

In het laatste hoofdstuk worden de bevindingen van deze studie geformuleerd. Vervolgens wordt op basis van een schets van de stand van zaken en van recente en te verwachten intra- inter- en metaprofessionele ontwikkelingen vooruit gekeken op de toekomst van de sociaalpsychiatrische verpleegkunde in Nederland. Concreet zullen onder meer aan de orde komen het vervagen van de grenzen tussen intramurale en extramurale psychiatrie, de voortgaande rationalisering in de zorgverlening plus de in hoofdstuk 1 al in het kort genoemde wijzigingen in de sociaalpsychiatrisch verpleegkundige opleiding. Er wordt ook stilgestaan bij een vrij recent ontstane tendens binnen de sociaalpsychiatrisch verpleegkundige beroepsgroep, hier gemakshalve samengevat onder de noemer "terug naar het sociaalpsychiatrisch gedachtegoed", bij achtergronden en motieven ervan en bij de betekenis ervan voor de inhoud en de plaats van het beroep sociaalpsychiatrisch verpleegkundige. 


\section{Hoofdstuk 5}

\section{De ontwikkeling van de sociale psychiatrie en de sociaalpsychiatrische verpleegkunde in Nederland van omstreeks 1940 tot omstreeks}

1985

\subsection{Inleiding}

In dit hoofdstuk komt om en nabij 45 jaar ontwikkeling van de sociale psychiatrie en de sociaalpsychiatrische verpleegkunde in Nederland aan de orde, te beginnen rond 1940.

Gedurende de Tweede Wereldoorlog, maar vooral vanaf het einde daarvan, groeit de extramurale geestelijke gezondheidszorg. Die groei gaat aan de sociale psychiatrie niet voorbij. Aantallen nazorgdiensten, psychiaters en vooral verpleegkundigen nemen toe. In het oog springt de groei van het aantal nazorgpatiënten in de jaren vijftig als gevolg van het beschikbaar komen van werkzame medicijnen waardoor meer patiënten kunnen worden ontslagen uit de inrichtingen. In diezelfde jaren groeit, eerst in de steden, later ook elders, de aandacht voor nog niet eerder opgenomen psychiatrische patiënten. De toch al moeizaam verlopende samenwerking tussen inrichtingen en nazorgdiensten wordt er niet beter op en een proces van institutionele verwijdering wordt zichtbaar. Tegen de achtergrond van de toenemende welvaart die financiering mogelijk maakt en van de opvatting dat ook minder ernstige psychiatrische problemen moeten en kunnen worden behandeld, blijft de extramurale psychiatrie groeien. Rond 1970 ontstaat onder invloed van denkbeelden uit de sociologie en de psychologie en door de komst van nieuwe professionals, zoals de psychologen, een psychotherapeutische oriëntatie. Inzicht en zelfontwikkeling worden belangrijke therapeutische doelen. De nazorg oude stijl, uitgevoerd door wat tot dan toe de twee kerndisciplines genoemd kunnen worden, te weten de verpleegkundigen en de psychiaters, raakt in de verdrukking.

Bemoeienis van de overheid, niet enkel financieel maar ook beleidsmatigorganisatorisch, leidt ertoe dat er een landelijk dekkend geheel van voorzieningen begint te ontstaan. Bereikbaarheid en betaalbaarheid worden daarbij nagestreefd. De subsidieregeling voor de Sociaal-Psychiatrische Diensten uit 1961, de financiering volgens de Algemene Wet Bijzondere Ziektekosten (AWBZ) vanaf 1971 en de Riaggvorming in 1982 zijn er voorbeelden van. 
Binnen dat zich ontwikkelende en uitbreidende domein spelen de verpleegkundigen een belangrijke rol. De beroepsgroep groeit in omvang met het domein mee. De taken van de verpleegkundigen blijven echter gedurende jaren betrekkelijk stabiel. In navolging van wat er zich in de sociale psychiatrie afspeelt, ontstaat in de jaren zeventig belangstelling voor zowel theoretische als praktische bijscholing, gericht op het verwerven van psychotherapeutische kennis en vaardigheden.

De ontwikkelingen van de opleiding van de verpleegkundigen, met als mijlpaal de start van een tweejarig voltijds programma op hbo-niveau in 1972, geven een goed beeld van de langzaam veranderende taakopvattingen en werkwijzen van de beroepsgroep. Zoals zal blijken uit onder meer berichten uit de in 1979 opgerichte beroepsvereniging worden de ontwikkelingen vrijwel vanaf het begin niet enkel positief beoordeeld, maar ook met bezorgdheid gevolgd. In hoofdstuk 7 wordt duidelijk hoe dat in de praktijk van alledag, ofschoon niet tot een tweedeling, dan toch tot divergentie leidt.

Vastgesteld kan worden dat de in het vorige hoofdstuk geconstateerde relatieve rust in het domein van de sociale psychiatrie en het evenwicht tussen en binnen de oorspronkelijke beroepsgroepen in dat domein, de psychiaters en de verpleegkundigen, vanaf omstreeks 1970 niet langer meer vanzelfsprekend is. Aan het einde van dit hoofdstuk wordt daarbij, en bij de gevolgen die dat heeft voor de professionalisering van de verpleegkundigen, stilgestaan.

De ontwikkelingen in de extramurale psychiatrie kunnen ook nu niet goed worden begrepen indien ze niet worden bekeken tegen de achtergrond van de inrichtingspsychiatrie. Dat is de reden om eerst een schets te geven van de inrichtingspsychiatrie in het tijdvak van omstreeks 1940 tot ongeveer 1985.

\subsection{Ontwikkelingen in de inrichtingspsychiatrie}

$\mathrm{Na}$ afloop van de Tweede Wereldoorlog is de situatie in de psychiatrische inrichtingen slecht. $\mathrm{Er}$ is schaarste aan middelen, de elementaire verzorging is onder de maat, er is plaatsgebrek en tekort aan personeel. Het duurt tot eind jaren vijftig eer de situatie enigszins is genormaliseerd. Het wegwerken van het personeelstekort duurt nog langer. Pas tegen 1970 wordt het ingelopen. ${ }^{216}$

De nog steeds weinig succesvolle behandeling bestaat, naast veel arbeidstherapie zoals manden vlechten, matten maken en naai-en verstelwerk, uit onder meer insuline-comatherapie en elektroshocktherapie, slaapmiddelen, kalmerende middelen en anti-epileptica. De introductie van de psychofarmaca, met als eerste Largactil, vanaf 1953, is van grote betekenis. Bij veel patiënten kunnen onrust, angst en agressie worden teruggebracht. De situatie in de inrichtingen verandert hierdoor

${ }^{216}$ Abma, R., \& Weijers, I. (2005). Met gezag en deskundigheid: de historie van het beroep psychiater in Nederland. Amsterdam: SWP, 145. 
grondig. Patiënten zijn beter benaderbaar en het gebruik van dwangmiddelen neemt af. "Ik herinner me het begin van het gebruik van Largactil nog heel goed... De invloed was geweldig, de verandering van die katatone beelden; als je dat hebt meegemaakt... het was echt een wonder". ${ }^{217}$ De verhouding tussen patiënten en personeel verandert er ook door. "Na deze revolutie werd het toepassen van lichamelijk geweld door verplegenden tegenover patiënten veel minder noodzakelijk (slechts af en toe in plaats van dagelijks vele malen)". ${ }^{218}$

Onder invloed van wat wordt genoemd het antropologisch perspectief ontstaat er aarzelend een nieuwe kijk op de omgang met patiënten: hun verhalen en behoeften krijgen meer aandacht dan voorheen. ${ }^{219}$ Aan het begin van de jaren vijftig wordt hier en daar geëxperimenteerd met individuele psychotherapie, groepstherapie en sociotherapie, maar zowel het chronische personeelstekort als het gebrek aan scholing van het personeel belemmeren de ontwikkelingen. ${ }^{220}$ In veel inrichtingen zijn geen of weinig psychiatrisch gespecialiseerde artsen. Hun aantal daalt tussen 1940 en 1960 van 195 naar $142 .{ }^{221}$ De geneeskundige inspectie maakt melding van een tekort aan leerling- en gediplomeerd verpleegkundigen van 20 procent in $1957 .{ }^{222}$

De aanwezige verpleegkundigen richten zich met name op huishoudelijke werkzaamheden en op het houden van toezicht op patiënten. "Tijd voor persoonlijke contacten was er vrijwel niet. Maar afgezien van dit tijdgebrek kregen de verplegenden... geen concrete richtlijnen en geen instructies, noch van de leidinggevende verplegende, noch van de afdelingsarts. Bovendien had men geen scholing ontvangen met betrekking tot het aangaan van kontakten met de patiënt". ${ }^{223}$

Het beeld in de inrichtingen wordt in de jaren vijftig bepaald door "grote inerte plassen van patiënten", chronici en ouderen. ${ }^{224}$ De aandacht van de psychiaters richt zich vooral op de nieuw opgenomen patiënten. Degenen die al langer zijn opgenomen gaan deel uitmaken van "het grote leger anoniemen... Men begroet hen vriendelijk op de zaalvisite, men weet zich nog enkele opvallende trekjes te herinne-

\footnotetext{
${ }^{217}$ Ibidem, 148.

${ }^{218}$ Bambang Oetomo, R. (1974). Patiënt, arts en verplegende: hun onderlinge betrekkingen, toen en nu. Tijdschrift voor Psychiatrie, 16, 387-413, 408.

${ }^{219}$ Abma, R., \& Weijers, I. Met gezag en deskundigheid: de historie van het beroep psychiater in Nederland, 150.

${ }^{220}$ Goei, L. de (2001). De psychohygiënisten: psychiatrie, cultuurkritiek en de beweging voor geestelijke volksgezondheid in Nederland, 1924-1970. Nijmegen: SUN, 235.

${ }^{221}$ Abma, R., \& Wijers, I. Met gezag en deskundigheid: de historie van het beroep psychiater in Nederland, 195.

${ }^{222}$ Goei, L. de. De psychohygiënisten: psychiatrie, kultuurkritiek en de beweging voor geestelijke volksgezondheid in Nederland, 1924-1970, 233.

${ }^{223}$ Bambang Oetomo, R. Patiënt, arts en verplegende: hun onderlinge betrekkingen, toen en nu, 408.

${ }^{224}$ Willem Arntsz Stichting (1996). Jaarverslag van de Willem Arntsz Stichting te Utrecht uit 1959. In J. Dankers, \& J. van der Linden, Van regenten en patiënten: de geschiedenis van de Willem Arntsz Stichting: Huis en Hoeve, Van der Hoeven Kliniek en Dennendal. Amsterdam; Meppel: Boom, 94.
} 
ren van de vroegere symptomatologie, doch hun achtergrond verbleekt en verdoezelt". 225

Toch staan de ontwikkelingen niet stil. Onder meer door het gebruik van de psychofarmaca loopt de gemiddelde opnameduur in de loop van de jaren langzaam terug. De inrichtingen beginnen te delen in de algemene welvaartsstijging. Met de invoering van de Algemene Wet Bijzondere Ziektekosten (AWBZ) in 1967 worden de kosten van langdurige opnemingen in psychiatrische inrichtingen helemaal vergoed. Er is sprake van een forse groei van de financiën voor de instellingen en de personeelstekorten kunnen langzaam worden weggewerkt. ${ }^{226}$

Tegelijkertijd groeit de kritiek op de medische oriëntatie en op wat als inhumane omstandigheden in psychiatrische inrichtingen worden beschouwd. Er wordt gepleit voor vernieuwing. Opvattingen van psychiaters en sociologen zoals Laing, Szasz en Goffman, gepubliceerd begin jaren zestig, en van Foudraine uit 1971 hebben veel invloed. ${ }^{227}$ De beweging van de kritische of antipsychiatrie ontstaat. Vanuit de samenleving, met name door de pers, worden de inrichtingen op de korrel genomen. "In een kritisch jargon, al dan niet van antipsychiatrische zijde, werd aangegeven wat er zoal aan de psychiatrische inrichting haperde: een medischbureaucratische structuur, een autoritaire mentaliteit, een massificerend en hospitalisatiesyndroom-bevorderend milieu, een onleefbare en verschraalde leefwereld, het opbergen, de vrijheidberoving, de medicamenteuze en andere dwangbuizerij, etc. etc." 228

De ontwikkelingen gaan ook aan werkers in de psychiatrie niet voorbij. Kritische psychiaters, psychologen en verpleegkundigen pleiten ervoor om de psychische problemen van patiënten in een sociale context te plaatsen zodat duidelijk kan worden waarom iemand in de moeilijkheden is gekomen. "Er moest worden gezocht naar de zin van de waanzin en dat kon door middel van praten". ${ }^{229}$ Patiëntbesprekingen en patiëntstafbesprekingen worden gehouden. In veel inrichtingen ontstaan

\footnotetext{
225 "Causerie gehouden door de geneesheer-directeur van het Willem Arntsz Huis op de vergadering van het College van Regenten op vrijdag 4 oktober 1960". In J. Dankers, \& J. van der Linden. Van regenten en patiënten: de geschiedenis van de Willen Arntsz Stichting: Huis en Hoeve, Van der Hoeven Kliniek en Dennendal, 94.

${ }^{226}$ Goei, L. de. De psychohygiënisten: psychiatrie, kultuurkritiek en de beweging voor geestelijke volksgezondheid in Nederland, 258.

${ }^{227}$ Laing, R.D. (1960). The divided self: a study of sanity and madness. London: Tavistock. Goffman, E. (1961). Asylums: essays on the social situation of mental patients and other inmates. Garden City: Anchor Books. Szasz, T. (1961). The myth of mental illness: foundations of a personal conduct. New York: Harper \& Row. Foudraine, J. (1971). Wie is van hout... . een gang door de psychiatrie. Baarn: Ambo. De Nederlandse edities van Laing, Goffman en Szasz komen vanaf 1969 ter beschikking. De kritiek op de inrichtingspsychiatrie maakt deel uit van de kritiek op de hele psychiatrie, dus ook op de sociale psychiatrie. Zie verderop in dit hoofdstuk onder Ontwikkelingen in de sociale psychiatrie.

${ }^{228}$ Eynde, I.E.I.M. van (1978). Enkele nieuwe woonvormen voor psychiatrische patiënten. Tijdschrift voor Psychiatrie, 20, 79-94, 79.

${ }^{229}$ Blok, G. (2004). Baas in eigen brein:'antipsychiatrie' in Nederland, 1965-1985. Amsterdam: Nieuwezijds, 202.
} 
verschillen van inzicht en, soms zeer heftige, conflicten tussen vernieuwers en behoudenden.

Er worden nieuwe vormen van psychotherapie ingevoerd, zoals groeps- en relatietherapie. Patiënten, die nu cliënten worden genoemd, krijgen in hoge mate de verantwoordelijkheid voor hun eigen functioneren en daarmee ook voor hun motivatie tot genezing en/of verandering en/of zelfactualisatie. "Vanaf het begin van de jaren zeventig heet de mislukte behandeling voortaan: de patiënt was onvoldoende gemotiveerd". 230

De vernieuwingen spelen zich vaak af aan wat wel de voordeur van de inrichtingen wordt genoemd, op de opname-afdelingen en de afdelingen voor kortdurend verblijf. Verblijfsafdelingen voor chronische en bejaarde patiënten zijn veelal niet of oppervlakkig betrokken bij de veranderingen. Het rapport "De chronische patiënt" uit 1973 geeft weliswaar een belangrijke impuls tot aandacht voor deze groep, maar het zal nog jaren duren eer er werkelijk veranderingen worden gerealiseerd. ${ }^{231}$

De patiënten, al dan niet vertegenwoordigd door derden, worden zichtbaarder dan voorheen. In 1971 wordt de Cliëntenbond in de Welzijnszorg opgericht en in 1973 komt voor de eerste keer de Gekkenkrant uit.

Vanaf 1970 groeit het aantal poliklinieken bij de psychiatrische inrichtingen van vijf naar 40, met 65 spreekuuradressen in 1978. ${ }^{232}$ Deze poli's hebben verschillende functies. Behalve het diagnosticeren van verwezen patiënten, opnamescreening en ambulante psychiatrische of psychotherapeutische behandeling vallen daar ook onder de zorg voor ontslagen patiënten en preventie van heropnemingen. De behoefte daaraan is stijgende. Dat is het gevolg van een groeiend aantal ontslagen, veroorzaakt door een stijging van de opname-aantallen en een daling van de opnameduur. De sociaalpsychiatrische diensten raken daardoor overvraagd. Die overvraging heeft overigens ook te maken met het feit dat de diensten zich in de loop van de jaren meer en meer zijn gaan richten op patiënten met zo genoemde psycho-sociale problemen en daardoor onvoldoende capaciteit hebben. Een bijkomende, niet onbelangrijke reden voor het instellen van de poliklinieken is de slechte samenwerking tussen inrichtingen en sociaalpsychiatrische diensten. Die samenwerking wordt er met de komst van de poliklinieken niet beter op. "De grote moeilijkheid is, dat de beide vormen van extramurale psychiatrische zorg zich zo volkomen los van elkaar

\footnotetext{
${ }^{230}$ Lieshout, P. van (1985). Veertig jaar geestelijke volksgezondheid: een analyse van het MGv. Maanblad Geestelijke volksgezondheid, 40, 1243-1274, 1270.

${ }^{231}$ Visiecommissie Psychiatrisch Centrum St. Bavo (1973). De chronische patiënt: tweede rapport van de visiecommissie. Noordwijkerhout: Psychiatrisch Centrum St. Bavo.

${ }^{232}$ Mastboom, J. (1981). Poliklinieken van psychiatrische centra: een beschrijvend onderzoek naar ontstaan, werkwijze, personele opbouw, taken en funkties van psychiatrische poliklinieken van psychiatrische centra ( $p p c$ 's) en een nadere positiebepaling binnen de geestelijke gezondheidszorg in Nederland in 1978. Utrecht: NcGv, 22.
} 
ontwikkeld hebben, terwijl ze, vanuit de essentie van het werk gedacht, een organische eenheid hadden moeten zijn vanaf het begin". ${ }^{233}$

De omvang van de nazorgtaak van de poliklinieken is overigens betrekkelijk klein. "Ongeveer 1 op de 5 ontslagen patiënten wordt door de psychiatrische centra zelf poliklinisch in nazorg gehouden" ${ }^{234}$ In een aantal gevallen komt de nazorg voor rekening van de huisartsen. Zij kunnen dat doen omdat er steeds betere medicijnen op de markt zijn gekomen. Ook vrijgevestigden en psychiaters van algemene en academische ziekenhuizen kunnen door ondersteuning met psychofarmaca begeleiding bieden aan extramurale patiënten. ${ }^{235}$

In 1974 is er voor de helft van de ongeveer 17.500 psychiatrische opnemingen geen poliklinisch of ambulant ggz-contact gedurende drie maanden vóór de opname. 25 Procent van de ongeveer 16.500 ontslagen patiënten heeft in de eerste drie maanden na ontslag geen contact met een poliklinische of ambulante ggzvoorziening. "Er is een aanhoudende stroom van klachten in kranten, weekbladen, vaktijdschriften en andere media over de gebrekkige nazorg en over de moeilijkheden bij opname, het ontbreken van een gedurende 24 uur bereikbare ambulante geestelijke gezondheidszorg. Zelfs de opkomst van de Paaz-poliklinieken biedt in dit opzicht geen soelaas. Immers ook deze instituten zijn zich, naast 'voorzorg' en 'nazorg', al gauw bezig gaan houden met cliënten voor wie een opneming niet nodig is" $^{\prime 236}$

Inmiddels krijgt, na het verschijnen van de "Nota Geestelijke Volksgezondheid" in 1971, de invloed van de overheid op de geestelijke gezondheidszorg duidelijker dan voorheen vorm. Regionalisering en echelonnering worden kernbegrippen. In de jaren erna blijft de overheid druk uitoefenen, bijvoorbeeld via de Structuurnota Gezondheidszorg uit 1974, om te komen tot een bereikbaar, samenhangend en betaalbaar geheel van intra- en extramurale voorzieningen. De nadruk ligt vooral op versterking van de extramurale psychiatrie die in staat moet worden gesteld een breed palet aan activiteiten te verrichten ten behoeve van een brede doelgroep. Opname in een inrichting, bij voorkeur kortdurend, wordt enkel nog op zijn plaats geacht voor mensen met ernstige problemen die tijdelijk extramuraal niet te handhaven zijn. Een en ander leidt in 1982 tot de komst van de Regionale Instellingen voor Ambulante Geestelijke Gezondheidszorg. Er wordt een begin gemaakt met de afbouw van de grote inrichtingen die plaats moeten maken voor allerlei vormen van transmurale en extramurale hulp- en zorgverlening.

\footnotetext{
${ }^{233}$ Lumeij, J.L J. (1961). Het werk van de Sociaal-Psychiatrische Dienst: een kritische bezinning op de huidige werkwijze en inhoud van het werk. Maandblad Geestelijke Volksgezondheid, 16, 207-218, 214/215.

${ }^{234}$ Mastboom, J. Poliklinieken van psychiatrische centra, 36.

${ }^{235}$ Abma, R., \& Weijers, I. Met gezag en deskundigheid: de historie van het beroep psychiater in Nederland, 149.

${ }^{236}$ Horn, G.H.M.M. ten (1979). Voorzorg, nazorg, geen zorg: de samenwerking tussen de ambulante en de klinische GGZ. Maandblad Geestelijke Volksgezondheid, 34, 669-672, 671.

PZ staat voor psychiatrisch ziekenhuis, PAAZ voor psychiatrische afdeling algemeen (en academisch) ziekenhuis.
} 


\subsection{Ontwikkelingen in de sociale psychiatrie van ongeveer 1940 tot omstreeks 1985}

Begin jaren veertig ontstaat er een proces van verzelfstandiging van de aan de inrichtingen verbonden buitendiensten. Hebben in 1940 van de 35 grote inrichtingen er veertien een buitendienst en wordt er op 31 plaatsen spreekuur gehouden, in 1949 zijn er nog elf buitendiensten met zeventien spreekuurlocaties. Het proces van verzelfstandiging van de diensten is in 1953 voltooid, op twee uitzonderingen na: de Valeriuskliniek in Amsterdam en de Willem Arntsz Stichting in Utrecht. ${ }^{237}$ In dat jaar zijn naar schatting "20 psychiaters vast en zo'n 35 psychiaters voor enkele dagen per maand aan deze bureaus verbonden, naast zo'n 65 sociaalpsychiatrisch verpleegkundigen in volledig dienstverband". 238

Een belangrijke reden voor die verzelfstandiging is het feit dat de inrichtingen niet voor een afgebakend verzorgingsgebied werken. De bereikbaarheid van de patiënten is daardoor bemoeilijkt en de kwaliteit van de dienstverlening is onder de maat. Een andere reden, samenhangend met de vorige, is van financiële aard. Gemeenten en provincies, die de zorg betalen, hechten aan goede voor- en nazorg, waarmee het aantal opnames kan worden verlaagd en de duur ervan kan worden beperkt.

Hoewel er sprake is van ontkoppeling van inrichtingen en nazorgdiensten, betekent dat niet dat de rol van de inrichtings- of klinische psychiatrie overal meteen is uitgespeeld. Op veel plaatsen blijven psychiaters, verbonden aan inrichtingen, verantwoordelijk voor de medische inbreng in de voor- en nazorgdiensten. Trimbos typeert hen als "... . psychiaters, die naast veel ander werk ook even het spreekuur van de voor- en nazorg doen, psychiaters met uitgesproken gestichtsmentaliteit, gespeend van psychisch-hygiënisch inzicht, sociaal ongeschoold en zonder belangstelling ...". ${ }^{239}$

Overeenstemming over de visie op de beide subspecialismen is er nog niet. Zo meent Barnhoorn, leider van de sociaalpsychiatrische dienst van de GG\&GD in Rotterdam, dat de belangrijke doelstellingen van de klinische psychiatrie, te weten diagnose, prognose en therapie, voor de sociale psychiatrie van secundair belang zijn. "Haar aandacht gaat in de eerste plaats uit naar de sociale relaties van de zieke in het verleden en het heden, naar zijn opvoedings- en levensmilieu, naar zijn ouderlijk gezin, zijn beroep en zijn arbeidsmilieu en naar de in de menselijke samenleving aanwezige sociale, economische, culturele en politieke factoren die op hem hebben

\footnotetext{
${ }^{237}$ Grinten, T.E.D. van der. (1987). De vorming van de ambulante geestelijke gezondheidszorg: een beleidshistorisch onderzoek. Baarn: Ambo, 184.

${ }^{238}$ Ibidem, 172. Het is moeilijk zicht te krijgen op psychiatrische formatieplaatsen. "Vast" betekent in dienst van de instelling en geheel of gedeeltelijk beschikbaar ten behoeve van voor- en nazorg.

${ }^{239}$ Trimbos, C.J.B.J. (1955). De ontwikkeling der voor- en nazorgdiensten in het kader der geestelijke volksgezondheid. Maandblad Geestelijke Volksgezondheid, 10, 53-62, 54.
} 
ingewerkt". ${ }^{240}$ In de inleiding van het leerboek "Sociale psychiatrie voor maatschappelijk werkenden", geschreven door twee inrichtingspsychiaters, staat daarentegen: "De studie van de sociale psychiatrie stelt kennis van de algemene psychopathologie en de klinische psychiatrie voorop". ${ }^{241}$

Organisatorisch is er aan het eind van de jaren vijftig op het gebied van de voor- en nazorg sprake van een lappendeken. Zo bestaan er provinciale stichtingen in Groningen, Friesland, Drenthe en Noord-Holland; gemeentelijke diensten in Amsterdam, Leiden, Haarlem, Rotterdam en Den Haag; particuliere plaatselijke stichtingen in Amsterdam, Den Haag en Rotterdam; een regionale stichting in Maastricht en omgeving en de voor- en nazorgdiensten van het Wit-Gele Kruis in Noord-Brabant en van het Groene Kruis in Limburg. Overijssel, Gelderland, Utrecht, Zuid-Holland en Zeeland kennen vormen van "provinciale federatieve samenbundeling op organisatorisch en beleidsniveau terwijl de uitvoering van het werk via levensbeschouwelijke zuilen uiteen valt" ${ }^{242}$ De inrichtingen verzorgen de intramurale behandeling, de nazorgdiensten verzorgen de nazorg, vrijgevestigde psychiaters en huisartsen doen de extramurale behandeling, dat wil zeggen: schrijven medicijnen voor. Het voeren van regie is moeilijk. "Veel meer dan uiteindelijk vrijblijvende afspraken over opnemingsen ontslagprocedures tussen de direct betrokkenen (huisarts, gemeentelijke diensten, vrijgevestigde zenuwartsen, voor- en nazorgdiensten en psychiatrische inrichtingen) zat er niet in". ${ }^{243}$

Een gevolg van de komst van de psychofarmaca is dat patiënten eerder dan voorheen uit de inrichtingen kunnen worden ontslagen. De vraag naar nazorg neemt toe, en daarmee ontstaat druk op de nazorgdiensten. Die diensten zijn zich vanaf halverwege de jaren vijftig langzaam, de steden voorop, steeds meer gaan bezighouden met cliënten die niet eerder in een inrichting opgenomen zijn geweest. $^{244}$

De samenwerking met de inrichtingen, voor zover die al naar tevredenheid verloopt, komt verder onder druk te staan. "De persoonlijke contacten tussen de psychiatrische diensten en inrichtingen zijn te oppervlakkig, te incidenteel, te weinig planmatig gericht op hetgeen zich met de patiënt afspeelt...". ${ }^{245}$ Het is lang niet altijd makkelijk om opnames gerealiseerd te krijgen en het komt regelmatig voor dat

\footnotetext{
${ }^{240}$ Barnhoorn, J.A.J. (1955). Sociale psychiatrie, geestelijke hygiëne, geestelijke gezondheidszorg en geestelijke volksgezondheid. Maandblad Geestelijke Volksgezondheid, 10, 1-40, 3.

${ }^{241}$ Havermans, F.M., \& Oosterbaan, W.M. (1954). Sociale psychiatrie voor maatschappelijk werkenden. Roermond; Maaseik: J.J. Romen en Zonen, 9.

Met maatschappelijk werkenden worden in dat boek bedoeld artsen, juristen, verpleegkundigen enz. .

${ }^{242}$ Trimbos, C.J.B.J. (1959). De geestelijke gezondheidszorg in Nederland. Utrecht; Antwerpen: Het Spectrum, 233-234.

${ }^{243}$ Grinten, T.E.D. van der. De vorming van de ambulante geestelijke gezondheidszorg: een historisch beleidsonderzoek, 181.

${ }^{244}$ In Limburg bijvoorbeeld duurt het tot begin jaren zeventig eer de voorzorg goed van de grond komt.

${ }^{245}$ Zuithoff, D. (1959). Samenwerking psychiatrische inrichtingen sociaal psychiatrische diensten. Maandblad Geestelijke Volksgezondheid, 14, 331-340, 336.
} 
ontslagen worden geregeld zonder dat de nazorgdienst voorbereidingen kan treffen of zelfs op de hoogte wordt gesteld. ${ }^{246}$

De samenwerking binnen de voor- en nazorgdiensten rond 1960 laat een vertrouwd beeld zien. "Het was werk in hecht teamverband. Eénmaal per week samen een dag op stap: bezoeken aan huis en aan instanties, spreekuur, gevalsbespreking. De zuster kende de patiënten, de huisartsen, de instanties, de politie; de psychiater zag de patiënten die zij voorstelde en zei hen zonodig wat de zuster hem vroeg te zeggen om de ernst van de boodschap te onderstrepen". ${ }^{247}$

In 1961 wordt de rijkssubsidieregeling voor Sociaal-Psychiatrische Diensten (S.P.D.) van kracht. Het al enigszins in onbruik geraakte begrip voor- en nazorgdienst verdwijnt en wordt vervangen door sociaalpsychiatrische dienst. De subsidieregeling houdt in dat de rijksoverheid 40 procent van de personeelslasten van de diensten voor haar rekening neemt. Als tegenprestatie wordt verlangd dat de diensten zich laten controleren door het Staatstoezicht en dat er minimaal een psychiaterdirecteur, een sociaalpsychiatrisch verpleegkundige en een administrateur aanwezig zijn. Niet verplicht aanwezig, maar wel onder de subsidieregeling vallende, zijn psychologen en psychiatrisch-sociaal werkenden. ${ }^{248}$ Met de regeling wordt de ontstane scheefgroei in financiële middelen voor een deel gecorrigeerd. Om een indicatie te geven, die in 1961 niet meer helemaal zal opgaan: in 1954 heeft de voor- en nazorgdienst in Rotterdam voor 700.000 inwoners $f 144.000$ beschikbaar. In datzelfde jaar heeft de voor- en nazorg in het noorden van Zuid-Holland voor evenveel inwoners $f 29.600$ beschikbaar. $^{249}$

Volgens de sociaalpsychiater Frets is het halverwege de jaren zestig dat de verwijdering tussen inrichtingen en sociaalpsychiatrische diensten, waaraan al eerder aandacht is besteed, haar beslag krijgt. Er worden door de inrichtingen minder patienten verwezen naar de diensten en er is minder overleg dan voorheen. Er ontstaat, ook door de verbeterde financiële situatie bij de diensten, ruimte om zich op nieuwe patiëntgroepen te gaan richten, zoals de groep die moeilijk of niet terecht kan bij de vrijgevestigden of dat niet wil, en de groep "stille thuiszitters, depressieven vooral". ${ }^{250}$ Geen psychotherapie, geen medicatie, maar het bezoeken van "depressieve huisvrouwen in de eigen setting, helpen hen de individuele listige hantering te vinden van het gevoelde onvermogen, zodat ze er niet doorheen poogden te werken,

\footnotetext{
${ }^{246}$ Frets, F.W. (1986). Van verheffing tot behandeling: ontwikkeling van de practische sociale psychiatrie. In J. Vijselaar (red.), Ambulant in zicht: geschiedenis van de ambulante geestelijke gezondheidszorg in Nederland. Utrecht: NcGv, 71 .

${ }^{247}$ Ibidem, 68.

248 Lendering, J., \& Meer, J. van der (2002). Volksgezondheidssubsidies: een institutioneel onderzoek naar het beleidsinstrument subsidiëring op het terrein van de volksgezondheid 1945-1997.

's Gravenhage: Rijksarchiefdienst PIVOT/Ministerie van Volksgezondheid, Welzijn en Sport, 36. Volgens deze bron heeft de rijksoverheid heeft al vóór 1961 incidenteel sociaalpsychiatrische diensten ondersteund en hen daarmee in staat gesteld met de vraag mee te groeien.

${ }^{249}$ Frets. F.W. Van verheffing tot behandeling; ontwikkeling van de practische sociale psychiatrie, 71

${ }^{250}$ Ibidem, 75.
} 
maar (lekker) wat anders deden". ${ }^{251}$ Het ziet ernaar uit dat de diensten buiten de inrichting cliënten vinden zonder ernstig ontregelende psychopathologie, die gebaat zijn bij langdurige begeleiding en ondersteuning.

Zoals dat het geval is bij de inrichtingspsychiatrie, komt ook de sociale psychiatrie rond 1970 onder toenemende kritiek te staan. Ook hier laat Trimbos van zich horen. "De psychiatrie echter, die in de Nederlandse sociaal- psychiatrische diensten wordt toegepast, is voor een overgroot deel klinische psychiatrie. De SPD-psychiatrie zou men een klein broertje kunnen noemen, dat hand- en spandiensten verleent ten eerste aan de 'echte' grote psychiatrie (inrichtingspsychiatrie) en ten tweede aan de volkseconomie door dure opnames te vertragen. De 'echte' zorg is de klinische zorg, terwijl de sociale psychiatrie zich bezighoudt met de voorzorg en de nazorg, dus als het ware niet met een eigen soort zorg" ${ }^{252}$ Trimbos pleit voor aandacht voor de emotionele en relationele conflicten van de patiënten, veroorzaakt door een deviant makende maatschappij, in plaats van het benadrukken van samenwerking tussen therapeut en patiënt die enkel leidt tot aanpassing van de laatste. De samenwerking, door hem agogische arbeid genoemd, "is voor onze samenleving geworden wat Odorex is voor een zwetend iemand, wat slagroom is voor een slechte bak kof$\mathrm{fie}^{\prime \prime}{ }^{253}$

De ontwikkelingen in de sociale psychiatrie gaan vanaf begin jaren zeventig snel. Ook hier worden nieuwe therapievormen zoals partnerrelatietherapie, gezinstherapie en gedragstherapie geïntroduceerd. Eigen verantwoordelijkheid en gemotiveerdheid van de patiënten, voortaan cliënten genoemd, worden, meer nog dan in de inrichtingspsychiatrie, belangrijk. Psychotherapie staat, vergeleken met wat wel het klussenwerk van de nazorgzuster wordt genoemd, in hoog aanzien. ${ }^{254}$ "De aandacht voor de sociale psychiatrie zoals die beoefend werd in de SPD-en verdwijnt nagenoeg geheel. Alles wat in de ambulante GGZ plaatsvindt, lijkt steeds meer op een van de vele vormen van welzijnszorg, namelijk psychosociale hulpverlening" ${ }^{255}$ Ofschoon deze conclusie wel erg kernachtig is geformuleerd, neemt dat niet weg dat de ontwikkelingen zich in een tot dan toe ongekend hoog tempo voltrekken.

Vanaf 1971 wordt ook de extramurale geestelijke gezondheidszorg gefinancierd uit AWBZ-gelden en ontstaat er ruimte om te groeien. In 1972 zijn er naar schatting 75.000 mensen in behandeling, waarvan 20.000 nieuw aangemelden. In 1975 werken er 1385 personen, waaronder 491 sociaalpsychiatrisch verpleegkundigen, 169 psychiaters, 149 psychologen en 91 maatschappelijk werkenden. ${ }^{256}$ Niet alle psychi-

\footnotetext{
${ }^{251}$ Ibidem, 75.

252 Trimbos, C.J.B.J. (1970). Perspektieven en wensen in de sociale psychiatrie. Maandblad Geestelijke Volksgezondheid, 25, 248-262, 249.

${ }^{253}$ Ibidem, 256.

254 Sorel, F.M. (1982). De nazorg nagelaten. Maandblad Geestelijke Volksgezondheid, 37, 1295-1305, 1300.

${ }^{255}$ Lieshout, P. van. Veertig jaar geestelijke volksgezondheid: een analyse van het MGv, 1265.

${ }^{256}$ Romme, M.A.J. (red.) (1978). Voorzieningen in de geestelijke gezondheidszorg: een gids voor consument en hulpverlener. Alphen aan den Rijn; Brussel: Samsom, 24.
} 
aters, psychologen en maatschappelijk werkenden hebben een voltijd aanstelling. Ze zijn ook werkzaam bij Medisch Opvoedkundige Bureaus of Bureaus voor Levensen Gezinsmoeilijkheden.

\subsection{Van nazorgzuster tot sociaalpsychiatrisch verpleegkundige}

\subsubsection{Nazorg en voorzorg}

Hoe vergaat het de verpleegkundigen tussen 1940 en 1985?

Met de groei van het domein van de sociale psychiatrie en de toename van het aantal verpleegkundigen, verandert er vooralsnog weinig aan hun taken en hun manier van werken. ${ }^{257}$ Ze blijven gericht op het buiten de inrichting houden van ontslagen patiënten. De werkzaamheden die ze daartoe verrichten bestaan voornamelijk uit het assisteren van de psychiater bij het spreekuur en het afleggen van vele huisbezoeken die voornamelijk controlerend en structurerend van aard zijn.

Als de nog niet eerder opgenomen patiënten in beeld komen, verandert er niet veel. "Het verschil tussen nazorg- en voorzorgpatiënten zat enkel en alleen in het feit dat de eersten een psychiatrische opname achter de rug hadden en de laatsten niet. In beide gevallen ging het om psychisch wankele personen die thuis, in de eigen omgeving, steun nodig hadden". ${ }^{258}$ Dat wordt nog eens onderstreept door de al eerder vermelde opmerking van een psychiater waaruit blijkt dat werkwijzen en samenwerking in de nazorg stabiel blijven. De eveneens eerder vermelde constatering dat de nazorg zich halverwege de jaren zestig in toenemende mate gaat richten op ondersteuning van de stille thuiszitters wijst ook in die richting. Van dezelfde strekking is de kritische opmerking die Trimbos in 1970 maakt over de SPD-psychiatrie die zich volgens hem bezig houdt met een eigen soort zorg die weinig is gericht op het bewerkstelligen van inzicht en veranderingen.

De verpleegkundigen vervullen een spilfunctie. "In 1972 startte ik met mijn opleiding sociale psychiatrie bij de GG\&GD in Amsterdam. Daar werd de dienst uitgemaakt door de spv-en, al bestond volgens de gebruikelijke medische traditie ook daar het gezag uit het toezicht dat enkele zenuwartsen uitoefenden. Maar het werk werd vooral gedaan door de 'dames' die er ieder een enorm wijkproject op nahielden". 259

De ontwikkeling in de opleiding geeft verder inzicht in de relatief stabiele taakuitoefening van de verpleegkundigen, waarin in de tweede helft van de jaren zeventig langzaam verandering komt. Die verandering geldt echter, zoals ook zal blijken

\footnotetext{
257 De groei van de groep verpleegkundigen kan worden afgeleid van de groei van de beroepsvereniging, zoals blijkt uit voetnoot 72 .

${ }^{258}$ Bakker, H., Goei, L. de, \& Vijselaar, J. (1994). Thuis opgenomen: uit de geschiedenis van de sociale psychiatrie in Nederland. Utrecht: NcGv, 38.

${ }^{259}$ Gersons, B.P.R. (1989). De SPV aan bod: verleden, heden en toekomst. Plektrum, 8 (27), 9-10, 9.
} 
bij bestudering van de beginjaren van de in 1979 op te richten beroepsvereniging, niet voor de hele beroepsgroep.

\subsubsection{Ontwikkelingen in de beroepsopleiding}

Met de opleiding van verpleegkundigen die extramuraal werken met psychiatrische patiënten, is, zoals al vermeld in de hoofdstukken 2 en 3, in 1924 een begin gemaakt. Meijers' Centrale Vereeniging tot Behartiging van de Belangen van Zenuwen Zielszieken start dan met de bijscholing aan wijkverpleegkundigen.

In 1937 ontstaat de opleiding B-nazorg. De opleiding is een initiatief van de $\mathrm{Ne}$ derlandse Vereniging voor Neurologie en Psychiatrie en wordt onder auspiciën van verschillende kruisorganisaties aangeboden, eerst in Utrecht, daarna aan onder meer de Rooms-Katholieke School voor Maatschappelijk Werk te Amsterdam (de latere Katholieke Sociale Academie Aemstelhoorn) en aan de Katholieke School voor Maatschappelijk Werk te Sittard.

Er wordt een heterogeen gezelschap verpleegkundigen afgeleverd, waarvan een deel vóór de beroepsopleiding enkel lagere school heeft gevolgd. "Het enige wat deze gediplomeerden wel gemeen hadden was dat ze geen van allen voor het moderne sociaalpsychiatrische werk waren toegerust". ${ }^{260}$ In 1942 zijn er in totaal 49 diploma's afgegeven. ${ }^{261}$ Het aantal lesuren van de opleiding wordt in 1958 uitgebreid tot 65; de stage duurt vanaf dan twee maanden. ${ }^{262}$ In de jaren 1962 tot en met 1966 krijgen respectievelijk 53, 39, 45, 53 en 41 verpleegkundigen het diplo$\mathrm{ma.}^{263}$

Een commissie van het Centrum Katholieke Psychiatrische Voor- en Nazorgdiensten, onder leiding van Trimbos, brengt in 1961 een "Rapport betreffende de opleiding van de gespecialiseerde verpleegster voor de Sociaal-Psychiatrische Diensten" uit. Zes jaar eerder heeft Trimbos de verpleegkundigen omschreven als "zusters die het veel te druk hebben, met gebrekkige vervoermiddelen hun rayon afjakkeren, in hun contacten soms nauwelijks boven het koffiepraatjeniveau uitstijgen; al te controlerende zusters die familie en buren vragen 'of alles nog goed gaat' en alweer op weg zijn naar het volgende van de vele duizenden huisbezoeken, die ze af te leggen

\footnotetext{
${ }^{260}$ Westhoff, H. (1996). Geestelijke bevrijders: Nederlandse katholieken en hun beweging voor geestelijke gezondheidszorg in de twintigste eeuw. Nijmegen: Valkhof Pers, 526.

${ }^{261}$ Commissie voor de Voortgezette Opleiding van Gediplomeerden B (1942). Vijfde jaarverslag over 1942. In R.K. Vereniging Het Limburgse Groene Kruis. Jaarverslag van de R.K. Vereniging Het Limburgse Groene Kruis. Waarschijnlijk gaat het om een copie uit de Psychiatrische en Neurologische Bladen.

${ }^{262}$ Nederlandse Vereniging voor Psychiatrie en Neurologie/Nationale Federatie voor Geestelijke Volksgezondheid (1969). Rapport betreffende de opleiding tot verpleegkundige voor Sociaal-psychiatrisch werk, 2.

${ }^{263}$ Ibidem. Bijlage, 4.

Onduidelijk is hoeveel verpleegkundigen er daadwerkelijk actief zijn. Aangenomen kan worden dat dat er minder zijn dan de som van de genoemde jaarcijfers. Het is niet ongebruikelijk, zoals ook blijkt uit voetnoot 51 , dat de verpleegkundigen stoppen met werken als ze trouwen.
} 
hebben...". ${ }^{264}$ Het is, volgens de commissie, tijd voor een goed opgeleide sociaalpsychiatrisch verpleegkundige, "niet langer het ondergeschikte verlengstuk, de hulp of assistente van de psychiater, maar een volledig zelfstandige teamkracht". ${ }^{265} \mathrm{Er}$ wordt gepleit voor een tweejarige opleiding met 684 lesuren en 6 maanden stage. Het niveau moet naar dat van de opleiding voor maatschappelijk werk, de vooropleiding naar het niveau van een middelbare opleiding. De eis van de aantekening wijkverpleging kan vervallen. ${ }^{266}$

De Nederlandse Vereniging voor Psychiatrie en Neurologie brengt in 1964 het zo genoemde Romprapport uit. Daarin wordt gesteld dat de opleidingsduur naar twee jaar moet en dat het diploma ziekenverpleging $A$ en de wijkaantekening niet meer nodig zijn. ${ }^{267}$ Op basis van het Romprapport wordt in 1966, op gezamenlijk initiatief van de Nederlandse Vereniging voor Psychiatrie en Neurologie en de Nationale Federatie voor Geestelijke Volksgezondheid, de Commissie Speyer ingesteld. ${ }^{268}$ De commissie bestaat onder meer uit drie psychiaters en twee verpleegkundigen, de directrices van de Aemstelhoorn en van het Seminarium voor Practische Gezondheidszorg in Leusden. Ze brengt in 1969 het "Rapport betreffende de opleiding tot verpleegkundige voor Sociaalpsychiatrisch werk" uit. Als vooropleiding heeft Havo de voorkeur, maar uit vrees voor een te lage instroom van studenten wordt dat Mavo/Mulo. De eis van de diploma's A en B blijft, de opleiding wijkverpleging is niet meer nodig. Het aantal lesuren wordt gesteld op 1320 en er is voorzien in een stage van negen maanden en in 40 uur supervisie. Het theoretische deel bestaat uit de onderdelen theorie en methodiek van het sociaalpsychiatrische werk (460 uur); methoden in relatie tot de vier hoofdtaken van de verpleegkundige voor psychiatrisch- sociaal werk, te weten uitvoerend werk, voorlichting, consultatie en bijdragen tot de beleidsvoering (340 uur); geestelijke en sociale stromingen (120 uur); gedragswetenschappen, te weten sociologie, sociale psychologie, psychologie,

\footnotetext{
${ }^{264}$ Trimbos, C.J.B. De ontwikkeling der voor- en nazorgdienst in het kader der geestelijke volksgezondheid, 54.

${ }^{265}$ Westhoff, H. Geestelijke bevrijders: Nederlandse katholieken en hun beweging voor geestelijke gezondheidszorg in de twintigste eeuw, 527.

${ }^{266}$ Het is aannemelijk dat van die commissie een verpleegkundige lid is. In het artikel SociaalPsychiatrische Dienst in Katholieke Gezondheidszorg, 1962, nr 3, 98-99 (zonder auteur) wordt districtszuster Van der Hek geportretteerd, "die deel heeft uitgemaakt van een commissie welke een plan tot herziening van de opleiding heeft ontworpen". Zij neemt in verband met haar huwelijk afscheid van de sociaalpsychiatrische dienst van de Katholieke Stichting voor Geestelijke Volksgezondheid in Utrecht. Van der Hek meent dat er sprake is van ballast, omdat de cursisten allemaal het B-diploma hebben. "Er is daarentegen veel meer behoefte aan oriëntatie op allerlei maatschappelijke terreinen, zoals b.v. kinderrecht. Er zou ook veel meer aandacht besteed moeten worden aan methodiek, rapportage, gesprekstechniek, case-work enz., want hiermee hebben we in de praktijk dagelijks te maken".

${ }^{267}$ Westhoff, H. Geestelijke bevrijders: Nederlandse katholieken en hun beweging voor geestelijke gezondheidszorg in de twintigste eeuw, 528.

${ }^{268}$ Speijer is hoogleraar sociale psychiatrie in Leiden.
} 
psychiatrie en pedagogiek (350 uur); recht en economie (80 uur). 200 Uur kunnen door de opleidingen naar eigen goeddunken worden ingevuld. ${ }^{269}$

Het rapport is niet zonder slag of stoot tot stand gekomen. Onenigheid onder de commissieleden over onder meer aantallen benodigde sociaalpsychiatrisch verpleegkundigen en over de organisatie en inrichting van de opleiding hebben de commissie doen overwegen de opdracht terug te geven. ${ }^{270}$ In de aanbiedingsbrief bij het rapport aan de minister van Sociale Zaken en Volksgezondheid stellen de besturen van de Nederlandse Vereniging voor Psychiatrie en Neurologie en van de Nationale Federatie voor Geestelijke Volksgezondheid dat ze van mening zijn "dat de tijd nog niet rijp is het voorstel van de commissie zonder meer over te nemen. Zij baseren zich daarbij mede op de overweging dat de opleiding tot verpleegkundige op het ogenblik integraal en verstrekkend wordt herzien, waarbij het zwaartepunt (wat) minder (sterk) bij het (klinisch) psychiatrische komt te liggen, zulks gepaard gaande met mogelijke herstructurering van organisatievormen van sociaalpsychiatrisch werk". ${ }^{271}$

In 1971 krijgt de Aemstelhoorn te Amsterdam van de minister groen licht om de opleiding tot sociaalpsychiatrisch verpleegkundige te beginnen onder de naam opleiding Maatschappelijke Gezondheidszorg afdeling Geestelijke Gezondheidszorg (MGZ/GGZ). De opleiding, tot dan toe gesubsidieerd door de Nationale Federatie voor de Geestelijke Volksgezondheid, wordt vanaf nu door de overheid gefinancierd. Twee jaar later wordt ze aangeboden in zeven plaatsen verbreid over het land, te weten Amsterdam, Leusden, Groningen, Sittard, Enschede, Breda en Nijmegen. Vanaf 1973 vervalt het diploma ziekenverpleging A als toelatingseis; het Bdiploma is voldoende. In 1979 zijn er in totaal 532 gediplomeerden afgeleverd. ${ }^{272}$

In 1974 begint in Leusden de eerste Kaderopleiding Extramurale Geestelijke Gezondheidszorg. De opleiding krijgt begin jaren tachtig de naam Voortgezette Opleiding Sociaal-Psychiatrische Verpleegkunde VO-SPV en wordt door opleidingsinstituten verspreid over het land aangeboden.

Inmiddels kunnen sinds 1965 ook mannen de opleiding wijkverpleging doen. Ze zijn daarmee toelaatbaar tot de B-nazorg. Met het vervallen van de wijkaantekening als toelatingseis tot de opleiding MGZ/GGZ neemt de instroom van mannen verder

\footnotetext{
${ }^{269}$ Nederlandse Vereniging voor Psychiatrie en Neurologie/Nationale Federatie voor de Geestelijke Volksgezondheid. Rapport betreffende de opleiding tot verpleegkundige voor Sociaal-psychiatrisch werk, 22-30.

${ }^{270}$ lbidem, 8 .

271 Ibidem, 1.

272 Doeve, E. (1980). Een analyse van het sociaalpsychiatrisch verpleegkundige beroep volgens het beroeps(vormings)model van Mok. Doctoraalscriptie Sociologisch Instituut, Rijksuniversiteit Groningen. Groningen: Rijksuniversiteit Groningen, 16. In dit aantal is inbegrepen een 20-tal Hbov-ers. Zie ook blz. 68.
} 
toe. In 1995 is de procentuele verhouding vrouwen-mannen in de beroepsgroep 4753 op een geschat totaal van 1500 à $1600 .^{273}$

De opleiding MGZ/GGZ wordt vanaf het begin gekoppeld aan de opleiding Maatschappelijke Gezondheidszorg/Algemene Gezondheidszorg (MGZ/AGZ), de voortzetting van de opleiding tot wijkverpleegkundige. Er bestaat eenzelfde leerplan, dat echter voldoende ruimte geeft om beide programma's afzonderlijk tot hun recht te laten komen. Aan de Aemstelhoorn in Amsterdam wordt deze koppeling al gauw ter discussie gesteld. De trend in de psychiatrie is om los te komen van "het medisch model en het medisch-organisch denken" ${ }^{274}$ Daarom dient het accent niet te zeer op het verpleegkundige gericht te zijn.

Gezamenlijk buigen de landelijke opleidingsinstellingen zich over thema's als eindtermen, toelatingsbeleid, stage, werkterrein van de afgestudeerden en de verhouding van de opleiding tot de opleiding maatschappelijk werk. Daarop hebben sociaal-wetenschappers in toenemende mate invloed. De verpleegkundige methodiek is ontleend aan de andragogie "omdat de opleiding zich richt op begeleidend en helpend bezig zijn". ${ }^{275}$ In de literatuurlijst van de Aemstelhoorn uit 1973 komen geen boeken voor over de vakken psychiatrie, sociale psychiatrie en sociaalpsychiatrische verpleegkunde.

De vraag wat specifiek verpleegkundig is komt regelmatig aan de orde. In 1976 formuleren de gezamenlijke opleidingen het antwoord daarop als volgt. "We kwamen ten slotte op het volgende uit: De EMGZ/GGZ onderscheidt zich van de opleiding M.W. (= maatschappelijk werk) door de andere gerichtheid. De kursisten hebben een klinische ervaring achter de rug die essentieel is voor de verdere opleiding omdat daardoor dingen anders geplaatst kunnen worden. Dit herkennen van ziektebeelden is zeker een pluspunt, in zekere zin ook het ermee om kunnen gaan, maar het gevaar ten aanzien hiervan is weer dat er teveel stigmatiserende elementen in kunnen zitten vanuit de B-opleiding". ${ }^{276}$

Er bestaat een Begeleidingscommissie voor de Opleiding tot SociaalPsychiatrisch Verpleegkundige, waarin participeren vertegenwoordigers van de opleidingen, de Nederlandse Vereniging voor Psychiatrie en Neurologie en de Nederlandse Vereniging van Sociaal-Psychiatrische Diensten. In 1975 wordt de commissie vervangen door de Begeleidingscommissie Opleiding SPV, die functioneert binnen de Nederlandse Vereniging voor Ambulante Geestelijke Gezondheidszorg. In deze commissies is de nagestreefde autonomie van de opleidingen ten opzichte van het werkveld regelmatig thema van discussie.

\footnotetext{
${ }^{273}$ Hoof, F. van, \& Wolf, J. (1995). Beroep: SPV: een onderzoek naar werk en toekomstperspectieven van sociaalpsychiatrisch verpleegkundigen. Utrecht: NcGv, 11.

${ }^{274}$ Palm, A.F.B.L. (1997). De opleiding tot sociaalpsychiatrisch verpleegkundige 1970-1995: een historisch onderzoek. Doctoraalscriptie Gezondheidswetenschappen, Universiteit Maastricht. Maastricht: Universiteit Maastricht, 40.

${ }^{275}$ Ibidem, 47.

${ }^{276}$ Notulen vergadering van de zeven opleidingsinstituten d.d. 5-1-1976, geciteerd in Palm, 54.
} 
Met het werkveld wordt moeizaam overlegd over de eisen waaraan de stageplaatsen en de begeleiding ter plekke moeten voldoen. Veel hebben de opleidingen niet te vertellen. "leder jaar bleken de opleidingsinstituten al blij te zijn als hun inspanningen om voldoende stageplaatsen te verwerven werden beloond, laat staan dat men toekwam aan een zekere mate van kwalitatieve toetsing" ${ }^{277}$ De opleidingen leggen dan ook elk hun eigen accenten omdat blijkt dat de functie van de verpleegkundigen sterk afhangt van de doelstellingen van de verschillende werkplekken. ${ }^{278}$

In 1979 stellen vertegenwoordigers uit het werkveld voor om een aangepaste opleiding voor sociaalpsychiatrisch verpleegkundige op te zetten, gericht op de oorspronkelijke nazorgpatiënten. Niet op het bewerkstelligen van veranderingen bij de patiënt, maar op revalidatie en milieubeïnvloeding moet de nadruk worden gelegd. De opleidingen zijn van mening dat daaraan voldoende aandacht wordt besteed en wijzen de gevraagde verandering af.

De Nederlandse Vereniging voor Ambulante Geestelijke Gezondheidszorg stelt in 1979 een werkgroep in die antwoord moet geven op de vragen welke taken een beginnend sociaalpsychiatrisch verpleegkundige moet kunnen uitvoeren, welke deskundigheden daarvoor nodig zijn, hoe die deskundigheden optimaal gerealiseerd kunnen worden en welke opvang een praktijkinstelling moet geven aan beginnende sociaalpsychiatrisch verpleegkundigen. In deze commissie hebben onder andere zes sociaalpsychiatrisch verpleegkundigen zitting. Het is voor het eerst dat er geen psychiater bij is. De sociaalpsychiatrisch verpleegkundige wordt in het door de commissie uitgebrachte rapport omschreven als "een hulpverlener binnen de GGZ, die is gericht op de totale kontekst van de hulpvrager, met name op de leefomgeving. De SPV probeert een beïnvloedend proces aan te gaan, dat vooral gericht is op de kliënt en diens omgeving". ${ }^{279}$ Omdat de verpleegkundige kennis heeft over lichamelijke, geestelijke en sociale aspecten van de mens, is hij een sleutelfiguur binnen de GGZ. "De opleiding tot verpleegkundige in de maatschappelijke gezondheidszorg biedt een voorbereiding op het uitoefenen van het verpleegkundige beroep in funkties op het terrein van de algemene resp. de geestelijke gezondheidszorg en biedt een verdere scholing aan verpleegkundigen $A$ en $B$. De vereiste attitude-ontwikkeling voor de beroepsuitoefening in de sektor van de maatschappelijke gezondheidszorg staat centraal in de opleiding". ${ }^{280}$

\footnotetext{
${ }^{277}$ Palm, A.F.B.L. De opleiding tot sociaalpsychiatrisch verpleegkundige 1970-1995: een historisch onderzoek, 45.

278 Doeve, E. Een analyse van het sociaalpsychiatrisch verpleegkundig beroep volgens het beroeps(vormings)model van Mok, 15.

${ }^{279}$ Werkgroep Eindpunt Opleiding SPV (1981). De SPV tussen opleiding en werkveld: nota van de Werkgroep Eindpunt Opleiding SPV. Nederlandse Vereniging voor Ambulante Geestelijke Gezondheidszorg: Utrecht, 4.

${ }^{280}$ Ibidem, 37.
} 
Volgens de erkenningsnormen voor Riagg's uit 1984 kunnen als sociaalpsychiatrisch verpleegkundige functioneren degenen met de opleiding Ziekenverpleging $A$, $B$, Kraamzorg, Wijkaantekening plus B-nazorg en degenen met de opleiding MGZ/GGZ. Houders van het diploma van de Hogere Beroepsopleiding voor Verpleegkundigen HBOV, waarvan de eerste zijn uitgestroomd in 1976, kunnen voor een ontheffing in aanmerking komen. Er zijn halverwege de jaren tachtig formeel dus drie mogelijkheden om sociaalpsychiatrisch verpleegkundige te worden. Daar de HBOV-ers met een geschat aantal van nog geen 20 ver in de minderheid zijn, bestaat de groep sociaalpsychiatrisch verpleegkundigen per saldo uit verpleegkundigen met twee verschillende typen opleiding: de B-nazorg en de MGZ/GGZ. ${ }^{281}$

Omstreeks 1970 komt de verdiepende nascholing op gang. Trainingen in gespreksvoering worden belangrijk. In de serie "Verpleegkundige Studies" verschijnt de publicatie "De spv en gezinsbehandeling". Daarin wordt onder meer uiteengezet waarom sociaalpsychiatrisch verpleegkundigen zich op gezinsbehandeling zouden moeten richten. ${ }^{282}$ Andere scholing, zoals op het gebied van gedrags- en relatietherapie, volgt. In 1985 brengt dat een sociaalpsychiatrisch verpleegkundige tot de constatering: "Ze willen allemaal therapeut worden. Ze willen op deze manier hun beroepsidentiteit verkrijgen". ${ }^{283}$

De vice-voorzitter van de Nederlandse Vereniging van Sociaal-Psychiatrisch Verpleegkundigen (NVSPV) reageert in 1981 op het "Advies inzake een beleid voor psychotherapie" van de Commissie Verhagen. ${ }^{284}$ Daaruit kan worden opgemaakt dat volgens het advies sociaalpsychiatrisch verpleegkundigen niet dienen te worden toegelaten tot de opleiding psychotherapeut. De auteur van de reactie is het daarmee niet eens. Er bestaat volgens haar te veel waardering voor een theoretische opleiding en te weinig voor specifieke vaardigheden die verpleegkundigen zich eigen maken door het werken in de praktijk van de extramurale geestelijke gezondheidszorg. Sociaalpsychiatrisch verpleegkundigen blijven echter uitgesloten van een registratie als psychotherapeut, omdat daarvoor een academische opleiding is vereist. $^{285}$

\subsubsection{De beroepsvereniging}

De zojuist genoemde NVSPV wordt in 1979 opgericht. De vereniging komt voort uit de Vergadering Contactpersonen SPV, een groep verpleegkundigen binnen de sectie

\footnotetext{
${ }^{281}$ Nederlandse Vereniging voor Ambulante Geestelijke Gezondheidszorg, Nederlandse Vereniging van Sociaal-Psychiatrisch Verpleegkundigen, \& Vereniging ter Behartiging van de Belangen van het Gezondheidszorgonderwijs (1987). Inzetbaarheid HBO-verpleegkundigen als spv. Utrecht, 10-11.

${ }^{282}$ Koppert, C. (1976). De spv en gezinsbehandeling. Lochem: De Tijdstroom, 35-36.

${ }^{283}$ Klinische les: verschrikkelijke ziektes (1985). Sociale Psychiatrie, 5(16), 13.

${ }^{284}$ Advies inzake een beleid voor psychotherapie (1981). Bulletin Nederlandse Vereniging van SociaalPsychiatrische Verpleegkundigen, 1-2.

${ }^{285}$ Hutschemaekers, G.J.M. \& Oosterhuis, H. (2004). Psychotherapy in The Netherlands after the Second World War. Medical History, 48, 429-449.
} 
sociale psychiatrie van de Nederlandse Vereniging voor Ambulante Geestelijke Gezondheidszorg.

Belangrijke reden om de vereniging op te richten is de behoefte aan meer invloed op de arbeidsvoorwaarden. Al gauw echter richt de vereniging zich vooral op beroepsinhoudelijke zaken. In de oprichtingsfase wordt duidelijk dat er ongerustheid heerst over de trend dat sociaalpsychiatrisch verpleegkundigen "te veel de richting van therapeut opgingen, en dat daarmee de nazorg, de zorg voor kansarmen, en de acute psychiatrie in het slop zouden komen. Bovendien vond men dat vanuit de opleidingen een positieve houding moest uitgaan naar de curatieve werkzaamheden voor de zogenaamde uitzichtsloze gevallen". ${ }^{286}$

Vanaf het begin wordt er gewerkt aan een beroepsprofiel, dat er na tien jaar, in 1989 , komt. Het thema beroepsidentiteit staat van meet af aan op de agenda, maar ook onderwerpen zoals de betekenis van religie in de hulpverlening, 24-uurs bereikbaarheid, en later vrouwenhulpverlening en aspecten van multi-culturaliteit.

De vereniging geeft een eigen tijdschrift uit en organiseert regelmatig studiemiddagen voor de leden. In 1980 heeft ze 300 leden. Dat aantal groeit tot 550 in $1985 .^{287}$

\subsection{Conclusies en discussie}

De periode waarover verslag is gedaan, wordt gekenmerkt door toenemende dynamiek en complexiteit. Maatschappelijke ontwikkelingen en ontwikkelingen in de geestelijke gezondheidszorg verlopen sneller dan voorheen, zeker vanaf de jaren zestig. De sociale psychiatrie raakt daarbij sterk betrokken en gaat er, meer dan voorheen, onderdeel van uitmaken.

Een in het oog springende ontwikkeling is de ontkoppeling van de buitendiensten en de psychiatrische inrichtingen. Die begint krap vijftien jaar nadat het verschijnsel buitendienst, bij Maasoord in Rotterdam in 1926, is ontstaan en is tegen de tweede helft van de jaren vijftig vrijwel voltooid. Er kunnen twee redenen worden gegeven voor de ontkoppeling. De eerste is de lage kwaliteit van de nazorg, veroorzaakt door de moeilijk te bedienen omvangrijke verzorgingsgebieden van veel van de buitendiensten. De tweede reden is het daarmee samenhangende kostenvraagstuk. Als goede nazorg niet is gegarandeerd, wordt tijdig ontslag verhinderd en groeit het risico op heropname. Dat kost geld en beheersing wordt noodzakelijk geacht. Vanaf 1953 wordt de sociale psychiatrie, op twee uitzonderingen na, uitge-

\footnotetext{
${ }^{286}$ Padt, I. van der (1999). Hoopvol bezorgd: sociaalpsychiatrische verpleegkunde van de $20^{e}$ naar de $21^{e}$ eeuw. Eindhoven: Nederlandse Vereniging van Sociaal-Psychiatrisch Verpleegkundigen, 148.

${ }^{287}$ Het ledenaantal loopt op van 680, 810, 1200 tot 2070 in resp. 1990, 1995, 2000 en 2005. Deze aantallen zijn ontleend aan het colofon van het blad van de NVSPV, met ingang van 1986 Plektrum en sinds 1991 Sociale Psychiatrie geheten. Uitgaande van de in hoofdstuk 1 vermelde hoge organisatiegraad van de sociaalpsychiatrisch verpleegkundigen geven deze cijfers een aanwijzing voor de groei van de beroepsgroep door de jaren heen.
} 
voerd door gemeentelijke en provinciale instanties en door kruisverenigingen. In de loop van het decennium komen daar nog enkele particuliere lokale en een regionale stichting bij.

Met de scheiding is de invloed van de klinische psychiatrie op de sociale psychiatrie niet voorbij. Er bestaat enkel klinische psychiatrie; zoiets als een praktijkdiscipline sociale psychiatrie is nog niet aan de orde. ${ }^{288}$ Daar komt nog bij dat lange tijd inrichtingspsychiaters, veelal parttime, de rol van sociaalpsychiater blijven vervullen. Het zijn ook inrichtingspsychiaters die bepalen of en welke patiënten met ontslag kunnen of met proefverlof ter voorbereiding daarop, en die bepalen of nazorg is geïndiceerd. In hoofdstuk 6 over de ontwikkelingen in Limburg en hoofdstuk 7 over ervaringen van sociaalpsychiatrisch verpleegkundigen, zal blijken dat er binnen de inrichtingen nauwelijks concrete denkbeelden bestaan, althans niet worden geuit, over mogelijkheden tot zorgverlening extramuraal.

De sociale psychiatrie als domein, waarvan de omvang groeiend maar nog steeds beperkt is, is tot ongeveer halverwege de jaren vijftig vrijwel uitsluitend gericht op het buiten de inrichting houden van ontslagen patiënten en de naam nazorg is een adequate typering van de functie. Met de oriëntatie op een andere categorie patienten, te weten de groep die nog niet opgenomen is geweest, ontstaat in de jaren vijftig voorzichtig aan de voorzorg. Die ontwikkelt zich eerst in de steden, later ook in de periferie, en wijkt niet veel af van de nazorg. De claim van de sociale psychiatrie is nog steeds een relatief overzichtelijke.

Tegen de achtergrond van de moeizame samenwerking met de inrichtingen, en zeker nadat door de Rijkssubsidieregeling voor Sociaal-Psychiatrische Diensten van 1961 daartoe financiële voorwaarden worden gerealiseerd, neemt en krijgt de sociale psychiatrie de ruimte om het domein verder uit te breiden. Aan de manier van werken verandert vooralsnog weinig. Ook aan de professionele bezetting van het domein verandert, op een uitzondering na, niets. Het blijven psychiaters en verpleegkundigen die het werk doen. De psychiaters houden consultatiebureau, bezoeken incidenteel patiënten in hun woonomgeving en geven adviezen. De verpleegkundigen leggen grote aantallen huisbezoeken af en, in mindere mate, bezoeken aan instanties om voorwaarden voor het extramurale verblijf van de patiënten mogelijk te maken. Gedacht kan worden aan huisvesting, financiële ondersteuning of werk.

De genoemde rijkssubsidiëring is niet alleen belangrijk vanwege de ruimere financiële armslag. Ze is bovenal de maatschappelijke erkenning van de noodzaak en het belang van de sociale psychiatrie. Sociale psychiatrie is een gevestigd onderdeel van de gezondheidszorg geworden.

\footnotetext{
${ }^{288}$ Sociale psychiatrie wordt vanaf 1960 als vak aan de universiteit gedoceerd. In 1982 wordt in de opleiding tot psychiater een stage sociale psychiatrie ingevoerd. De neurologiestage verdwijnt dan. Abma, R., \& Weijers, I. Met gezag en deskundigheid: de historie van het beroep psychiater in Nederland, 165.
} 
In een aantal gevallen, zoals in de provincie Limburg en in Amsterdam, komt het tot een vooralsnog organisatorische bundeling van vormen van extramurale geestelijke gezondheidszorg, waaronder Sociaal-Psychiatrische Diensten, MedischOpvoedkundige Bureaus en Bureaus voor Levens- en Gezinsmoeilijkheden. Daarmee wordt vooruitgelopen op de Riagg-vorming die in 1982 wordt geëffectueerd.

De grote veranderingen voltrekken zich vanaf begin jaren zeventig. Daaraan geeft de AWBZ-financiering van de sociale psychiatrie met ingang van 1971 een belangrijke impuls. Het aantal werkers groeit in de jaren daarna sterk en die groei is niet beperkt tot psychiaters en verpleegkundigen. Nieuwe beroepsbeoefenaren maken hun entree, zoals psychologen en maatschappelijk werkenden.

De invloed van onder meer de antipsychiatrie en van de groeiende vraag naar hulp bij wat wel psycho-sociale problemen of levensproblemen worden genoemd, dragen eveneens bij aan de veranderingen. Het aandachtspunt van de sociale psychiatrie verschuift van voor- en nazorg "oude stijl" naar extramurale behandeling van mensen met psychiatrische problemen. Dat wil overigens niet zeggen, zoals wel vaker is gesuggereerd, dat de nazorg "oude stijl" in korte tijd tot het verleden behoort.

De opleiding tot psychiater is nog steeds een opleiding tot klinisch psychiater en daarmee weinig maatschappelijk georiënteerd. De opleiding tot sociaalpsychiatrisch verpleegkundige is nog altijd de B-nazorg, die weinig aanknopingspunten biedt tot extramurale zorgverlening. Specifieke deskundigheid, anders dan voortkomend uit persoonlijke kenmerken, vaardigheden en ervaring, is nog steeds niet voorhanden. Het zal tot in de tweede helft van de jaren zeventig duren eer daar, met de uitstroom van de nieuwe opleiding MGZ/GGZ en de beginnende inhoudelijke bijscholing, verandering in komt. Het is niet aannemelijk dat psychiaters en verpleegkundigen hun manier van werken zo maar kunnen of willen aanpassen. Ze, althans een deel van hen, blijven hun oude stiel nog jaren uitoefenen, ook al zullen ze ongetwijfeld worden beïnvloed door de veranderingen. De hegemonie van de psychiaters en de verpleegkundigen binnen de Sociaal-Psychiatrische Diensten mag dan weliswaar voorbij zijn, dat wil nog niet zeggen dat daarmee ook een einde komt aan hun opvattingen over en concretisering van de sociale psychiatrie. Het is eerder zo dat er binnen de Sociaal-Psychiatrische Diensten een tweedeling ontstaat tussen gevestigde en vernieuwende opvattingen en dat die tweedeling ook ontstaat binnen de psychiatrische en de verpleegkundige beroepsgroep. Meer concreet: er ontstaat een zekere mate van divergentie tussen sociale psychiatrie en extramurale psychiatrie en tussen sociaalpsychiatrisch werkenden en extramuraal psychiatrisch werkenden. Uitspraken van sociaalpsychiatrisch verpleegkundigen die in de jaren zeventig werkzaam zijn, geven mede aanleiding tot het trekken van deze conclusie. In hoofdstuk 7 wordt hier nader op ingegaan. Ook de ontwikkelingen in de opleiding tot sociaalpsychiatrisch verpleegkundige en opmerkingen uit de kring van de in 1979 opgerichte NVSPV onderbouwen de hiervoor gemaakte gevolgtrekking. 
De inspanningen om te komen tot een nieuwe opleiding dateren van begin jaren zestig en resulteren in de eerste gediplomeerden in 1974. Daarmee wordt een belangrijke stap in het professionaliseringsproces van de verpleegkundigen gezet. Aanvankelijk zijn de psychiaters duidelijk betrokken bij het plannen en het inrichten van de opleiding, maar ook verpleegkundigen nemen eraan deel. Er komt een breed en gevarieerd programma op Hbo-niveau tot stand, dat in inhoud en omvang duidelijk afwijkt van de oude B-nazorg.

De opleiding, die gelet op het aantal uitstromers blijkbaar in een behoefte van de verpleegkundigen voorziet, streeft met succes, maar niet zonder problemen, naar autonomie. Vanaf het begin wordt door het werkveld van de sociale psychiatrie de zorg geuit dat er in het curriculum te weinig aandacht is voor de oorspronkelijke nazorgpatiënten. Het moeizaam vinden van stageplaatsen voor studenten kan in dat licht worden gezien. Pogingen van de opleiding om aan te geven wat er specifiek is aan het curriculum en aan de opgeleiden, blijven beperkt tot vrij algemeen geformuleerde, weinig operationele omschrijvingen. Het is niet duidelijk of het gaat om een politieke stellingname, bedoeld om rekening te houden met de geluiden uit het werkveld. Niet uitgesloten is dat het nog niet goed lukt om een min of meer afgebakende omschrijving te geven van het domein van de sociaalpsychiatrische verpleegkunde. De opmerking dat sociaalpsychiatrisch verpleegkundigen zich onderscheiden van maatschappelijk werkenden door het feit dat ze ervaring hebben in de kliniek, lees met psychopathologie, is in dit verband veelzeggend. Dat die ervaring zowel een voordeel als een nadeel kan zijn in het dagelijkse werk zegt iets van de ambivalentie die er bij de opleiders bestaat in het denken over zowel de opleiding als het werk van de sociaalpsychiatrisch verpleegkundigen. Diezelfde ambivalentie wordt gevonden in geluiden uit de pas opgerichte sociaalpsychiatrisch verpleegkundige beroepsvereniging. De constatering dat teveel verpleegkundigen zich tot therapeut ontwikkelen en dat daardoor te weinig aandacht blijft voor de "kansarmen en de zogenaamde uitzichtloze gevallen" geeft aan dat het, al is het maar in het praten over, niet afgelopen is met de nazorgfunctie van de sociaalpsychiatrisch verpleegkundigen.

Vooruitlopend op wat er in hoofdstuk 7 en 8 aan de orde komt, kan nu al worden gesteld dat wat hier wordt genoemd "de oude nazorgfunctie", en in de jaren negentig wordt aangeduid als "het sociaalpsychiatrisch gedachtegoed", in welke vorm dan ook, ondanks alle veranderingen en ontwikkelingen, nooit helemaal verdwijnt.

In de periode van omstreeks 1940 tot omstreeks 1985 ontwikkelt de sociale psychiatrie zich tot een zelfstandig en gevestigd domein in de Nederlandse gezondheidszorg. Het domein groeit gestaag; het aantal werkzame psychiaters en verpleegkundigen neemt toe. De claim van de sociale psychiatrie blijft, net als voor de oorlog, vooralsnog overzichtelijk, te weten het buiten de inrichting laten verblijven van psychiatrische patiënten. Dat gebeurt, gezien de gestage groei, blijkbaar succes- 
vol. Net als voor de oorlog zijn de activiteiten van de twee actieve beroepsgroepen, de psychiaters en de verpleegkundigen, nauwelijks operationeel omschreven. De domeinspecifieke ontwikkeling van beide groepen is nauwelijks verder gekomen.

Ook in de verdeling van de werkzaamheden tussen de twee groepen is niet veel veranderd. De psychiaters leiden de diensten en houden consultatiebureau, de verpleegkundigen leggen grote aantallen huisbezoeken af. Binnen en tussen de twee beroepsgroepen bestaat nog steeds domeinconsensus en ideologische consensus, tussen de groepen bestaat werkcoördinatie en klaarblijkelijk een positief oordeel over elkaars activiteiten. Anders gezegd: er is evenwicht tussen en binnen de beide groepen, of, in de van Benson afgeleide termen: er bestaat intra- en interprofessionele coherentie.

Aan het begin van de jaren zestig dienen zich veranderingen aan. De subsidieregeling kan worden beschouwd als een mijlpaal in de maatschappelijke erkenning van de sociale psychiatrie. Ze kan worden gezien als een voorbeeld van metaprofessionele invloed op het domein en de daarin opererende beroepsgroepen. Het belang daarvan, met name op de formatieruimte, moet niet worden onderschat.

Niet onderschat moeten echter ook worden activiteiten van psychiaters, die in 1961 en in 1964 in rapporten kenbaar maken dat ze van mening zijn dat er iets moet veranderen aan de opleiding, en dus ook aan de manier van werken van de verpleegkundigen. De eerder geconstateerde interprofessionele congruentie is niet meer zo vanzelfsprekend als voorheen. Maar er is meer. Gezien het belang van het functioneren van de verpleegkundigen voor de hele sociale psychiatrie kunnen de rapporten ook worden gezien als een signaal van de psychiaters dat er verandering nodig is in de sociale psychiatrie als zodanig. Daarmee is ook de intraprofessionele coherentie binnen de psychiatrische beroepsgroep niet langer meer vanzelfsprekend.

De nieuwe opleiding voor de verpleegkundigen komt er begin jaren zeventig. Dat is, zoals al eerder gezegd, een belangrijk moment in de professionalisering van de beroepsgroep. Voor het eerst hebben de verpleegkundigen in de sociale psychiatrie, althans heeft een vertegenwoordiging van de beroepsgroep, duidelijk inbreng in de inhoud en de organisatie van de opleiding. Dat zegt iets over de verschuiving in de verhouding tussen verpleegkundigen en psychiaters, maar ook over verschuivingen binnen de verpleegkundige groep. Er zijn blijkbaar verpleegkundigen die van mening zijn dat er aan de opleiding, en dus ook aan de manier van werken van de verpleegkundigen, iets moet veranderen. De intraprofessionele coherentie is niet langer meer vanzelfsprekend. 


\section{Hoofdstuk 6}

\section{Sociale psychiatrie in de provincie Limburg tot omstreeks 1975: van achterstand tot voorsprong}

\subsection{Inleiding}

In dit hoofdstuk ${ }^{289}$ wordt geschetst hoe zich in de provincie Limburg de sociale psychiatrie heeft ontwikkeld en hoe daarin de sociaalpsychiatrisch verpleegkundigen een positie hebben gekregen en welke die is. Daartoe wordt een institutionele analyse gemaakt van de sociale psychiatrie in de provincie Limburg. Bekeken wordt hoe ontstaan en ontwikkeling in Limburg verlopen en hoe ze kunnen worden verklaard. Dat gebeurt aan de hand van literatuur, van jaarverslagen en archiefstukken van het toenmalige Limburgse Groene Kruis en van de voormalige Venrayse inrichtingen Sint Servatius en Sint Anna. Daarnaast worden de resultaten van een analyse van statussen van patiënten uit beide inrichtingen uit de periode 1938-1973 gepresenteerd. De analyse spitst zich toe op de in de statussen terug te vinden vermeldingen van contacten tussen de inrichtingen en instanties erbuiten.

Aan het einde van het hoofdstuk wordt de vraag beantwoord in hoeverre de ontwikkelingen in Limburg overeenkomen met de ontwikkelingen elders in Nederland. Daarop vooruitlopend kan worden gezegd dat de ontwikkelingen in Limburg hun eigen dynamiek hebben en op onderdelen specifiek zijn voor de omstandigheden aldaar. In grote lijnen komen ze echter overeen met wat zich elders in het land, hoewel eerder en sneller, voltrekt. Ze kunnen worden gezien als bevestiging van de ontwikkelingen in het grotere geheel van de Nederlandse sociale psychiatrie tot omstreeks 1975.

\subsection{Begin van de psychiatrische nazorg in Limburg}

De nazorg voor psychiatrische patiënten in de provincie Limburg ontstaat relatief laat en ontwikkelt zich aarzelend. De, voor zover bekend, eerste vermelding ervan stamt uit 1929. De directie van de Venrayse inrichting Sint Anna laat in het jaarverslag weten dat het door een tekort aan geneeskundig personeel niet is gekomen van

\footnotetext{
${ }^{289}$ Dit hoofdstuk is een bewerking van Brouns, G., Philipsen, H., Diederiks, J. \& Meertens, P. (2007). Sociale psychiatrie in de provincie Limburg tot omstreeks 1975: van achterstand tot voorsprong. In Knotter, A. \& Rutten, W, (red.). Studies over de sociaal-economische geschiedenis van Limburg. Maastricht: Sociaal Historisch Centrum voor Limburg.
} 
een buitendienst. Daarna wordt er pas in 1936 weer melding gedaan van nazorg, beter gezegd van het nog niet van de grond komen ervan. ${ }^{290}$ De directie van Sint Anna staat op het standpunt dat de organisatie van de nazorg niet door de inrichting dient te worden georganiseerd, "maar door een algemeener lichaam, zij het ook in overleg en met medewerking van de inrichting". ${ }^{291}$ Die medewerking kan worden gerealiseerd door het beschikbaar stellen van een psychiater als leider van het consultatiebureau, en een verpleegkundige die hem als hulp terzijde staat. Het "algemeener lichaam" bestaat al in de vorm van de Rooms Katholieke Vereeniging Het Limburgsche Groene Kruis. $^{292}$

Dat Groene Kruis ziet voor zichzelf, behalve op het gebied van somatiek, taken weggelegd op het terrein van de geestelijke gezondheidszorg en hygiëne. In 1935 heeft het, na drie jaar voorbereiding, de Commissie voor Geestelijke Volksgezondheid ingesteld waarin de twee Limburgse inrichtingen, Sint Servatius voor mannen en Sint Anna voor vrouwen, een belangrijke rol spelen. ${ }^{293}$ De commissie komt tot stand in navolging van de in 1930 opgerichte Rooms Katholieke Charitatieve Vereeniging voor Geestelijke Volksgezondheid. Deze vereniging, opgericht door de Brabantse psychiater Kortenhorst, is een koepelorganisatie van katholieke inrichtingen, organisaties en verenigingen op het gebied van de geestelijke gezondheidszorg en kan worden beschouwd als de katholieke tegenhanger van de in 1924 opgerichte Nederlandse Vereniging voor Geestelijke Volksgezondheid. ${ }^{294}$ De taken van de commissie bestaan uit het oprichten van consultatiebureaus, het organiseren van cursussen en het geven van bekendheid aan het werk van de Geestelijke Volksgezondheid. Aan het hoofd van de consultatiebureaus zal een psychiater staan die, naast het leiden van het bureau, tot taak heeft het geven van cursussen aan wijkverpleegkundigen en aan opvoeders in de voogdij, het geven van adviezen aan schoolartsen en kinderpolitie en het adviseren bij de nazorg van psychiatrische patienten. ${ }^{295}$ Het honorarium van de psychiater wordt vastgesteld op vijf gulden per zitting "terwijl de beambte uit uw inrichting... daarvoor een vergoeding van $f$ 1-per dag zal genieten. Voor het door deze beambte te verrichten huisbezoek zal... naast vergoeding voor reis- en verblijfskosten, $f$ 1- per dag dat hij werkzaam is, betaald

\footnotetext{
${ }^{290}$ Verslag St. Anna. In Vereeniging van R.K. Gestichten en Inrichtingen (1936). Achtste jaarboek der Vereeniging van R.K. Gestichten en Inrichtingen 1936, 26.

${ }^{291}$ Ibidem, 26.

292 Ibidem, 27.

${ }^{293}$ R.K. Vereeniging Het Limburgsche Groene Kruis (1935). Jaarverslag R.K. Vereeniging Het Limburgsche Groene Kruis 1935, 153.

De geneesheer-directeur van Sint Anna is jaren voorzitter van de commissie.

${ }^{294}$ Grinten, T.E.D. van der. De vorming van de ambulante geestelijke gezondheidszorg: een historisch beleidsonderzoek, 83.

${ }^{295}$ R.K. Vereeniging Het Limburgsche Groene Kruis (1934). Jaarverslag R K. Vereeniging Het Limburgsche Groene Kruis 1934.
} 
worden" ${ }^{296}$ De eerste beambte bij aanvang van de nazorg voor vrouwen én voor mannen is een vrouwelijke verpleegkundige in dienst van Sint Anna. ${ }^{297}$

\section{3 De consultatiebureaus in Limburg}

Op 5 mei 1936 wordt in Venray, onder de vlag van het Groene Kruis, het Consultatiebureau voor Geestelijke Volksgezondheid geopend. Voor nazorg kunnen patiënten terecht op een spreekuur, dat twee keer per maand plaatsvindt in het Sint Elisabethziekenhuis; één keer voor mannen, één keer voor vrouwen. Het spreekuur voor mannen wordt gehouden door een psychiater van Sint Servatius, dat voor vrouwen door een psychiater van Sint Anna. De psychiaters worden tijdens het spreekuur geassisteerd door de verpleegkundige, die in voorkomende gevallen ook patiënten thuis bezoekt.

Het loopt aanvankelijk allerminst storm bij de spreekuren. In 1936 komen bij het bureau voor mannen onder anderen zes kinderen met leer- en opvoedingsmoeilijkheden. ${ }^{298}$ Het bureau voor vrouwen wordt door zeventien patiënten, waaronder vijf kinderen, 34 keer bezocht. Twee verwijzingen gebeuren vanuit de inrichtingen. ${ }^{299}$ De lage bezoekersaantallen voldoen niet aan de verwachtingen, zoals blijkt uit een brief van de geneesheer-directeur van Sint Anna aan de secretaris van het Groene Kruis. "Het lijkt me dat meer propaganda gemaakt moet worden, eventueel gemeentebesturen of huisartsen in Limburg in kennis gesteld van het bestaan van het bureau". ${ }^{300}$ Daarop wordt actie ondernomen. Patiënten die met ontslag gaan zullen een kaart meekrijgen met gegevens van de bureaus erop én de aansporing de bureaus te bezoeken. ${ }^{301}$ Aan de plaatselijke afdelingen van het Groene Kruis en alle gemeenten in de provincie Limburg gaat in 1937 een brief over het bestaan van het consultatiebureau in Venray en het inmiddels in 1937 opgerichte bureau in Maastricht. $^{302}$ Het aantal patiënten dat de bureaus bezoekt blijft ook in de jaren 1937, 1938 en 1939 laag. Het aantal kinderen, veelal verstandelijk gehandicapt, blijft verhoudingsgewijs hoog.

\footnotetext{
${ }^{296}$ Brief d.d. 23-3-1936 van de secretaris van het Groene Kruis aan de directeur van St. Servatius. In R.K. Vereeniging Het Limburgsche Groene Kruis (1936). Archief R.K. Vereeniging Het Limburgsche Groene Kruis, map 120.

${ }^{297}$ Geschiedenis St. Anna en St. Servatius en Paschalis (2002). Gebundelde reader. Vincent van Gogh Instituut: Venray, 10.

Niet duidelijk is of het een religieuze of een lekenverpleegkundige is. In de gezinsverpleging van St. Anna zijn in die tijd zowel religieuze als lekenverpleegkundigen actief.

${ }^{298}$ R.K. Vereeniging Het Limburgsche Groene Kruis (1936). Jaarverslag R.K. Vereeniging Het Limburgsche Groene Kruis 1936, 150.

${ }^{299}$ Ibidem, 151

${ }^{300}$ R.K. Vereeniging Het Limburgsche Groene Kruis. Brief d.d. 21 mei 1936. In Archief R.K. Vereeniging Het Limburgsche Groene Kruis, map 120.

${ }^{301}$ R.K. Vereeniging Het Limburgsche Groene Kruis. Jaarverslag R.K. Vereeniging Het Limburgsche Groene Kruis 1936, 151.

${ }^{302}$ R.K. Vereeniging Het Limburgsche Groene Kruis. Archief R.K. Vereeniging Het Limburgsche Groene Kruis, map 121.
} 
Omdat het bureau in Venray moeilijk bereikbaar is, wordt het per 1 juli 1940 gesloten. Ter vervanging worden vestigingen in Venlo en Roermond geopend. Ook in Heerlen wordt in 1940 een consultatiebureau opgericht. De drie plaatsen krijgen in dat jaar ook een bureau voor opvoedingsmoeilijkheden. In Maastricht bestaat dat al sinds 1937. Deze bureaus kampen vanaf het begin met personeelsproblemen en functioneren na 1943 feitelijk niet meer. ${ }^{303}$ Het zal tot in de tweede helft van de jaren vijftig duren eer daar verandering in komt.

De nazorgdiensten zijn er niet voor behandeling, voor dat wat in later jaren gedragsverandering zal worden genoemd. De directie van Sint Anna formuleert in 1940 als functies van de dienst: het voorbereiden van proefverlof en ontslag; het, al dan niet via de wijkverpleegkundige, controleren van de patiënt zodat die geen gevaar voor zijn omgeving is; het geven van omgangsadviezen aan naasten van de patiënt; het geven van informatie aan de psychiaters; het treffen van sociale voorzieningen zoals het regelen van financiële steun, huisvesting, huishoudelijk hulp en passend werk. ${ }^{304}$ Indien er medicijnen worden voorgeschreven gebeurt dat door de huisarts of een andere medicus, in elk geval niet door de nazorgpsychiater. Hoewel de aantallen bezoeken niet overweldigend zijn, wordt er door nazorgpsychiaters toch behoefte geuit aan uitbreiding van de diensten.

\subsection{De komst van de nazorgzuster in Limburg}

Een belangrijke gebeurtenis is de indiensttreding van een verpleegkundige bij het Groene Kruis op 1 juni $1940 .^{305}$ Het belang van de komst van de verpleegkundige, aanvankelijk provinciaal huisbezoekster, later nazorgzuster genoemd, blijkt uit de grote aantallen huisbezoeken die door haar worden afgelegd. In 1940 zijn er dat 339. Daarna stijgt het aantal tot 1604 in 1943, waarna, waarschijnlijk als gevolg van de oorlog, een daling inzet tot 473 in 1945 . Met de komst van een tweede nazorgzuster in 1946 stijgt het aantal bezoeken tot 1915 in dat jaar en tot 2135 in $1947 .^{306}$

De verhouding tussen voor- en nazorghuisbezoeken begint meteen aanzienlijk te verschuiven richting nazorg. Bij bezoeken aan de consultatiebureaus is het aantal voorzorgcontacten iets groter dan het aantal nazorgcontacten. De hoeveelheid acti-

\footnotetext{
${ }^{303}$ Philips, J.F.R. (1960). 50 Jaar Limburgse Groene Kruis: 50 jaar sociale gezondheidszorg in Limburg: de R.K. Vereniging Het Limburgse Groene Kruis in het goud, 1910-1960. Sittard: R.K. Vereniging Het Limburgse Groene Kruis, 208.

${ }^{304}$ Verslag St. Anna. In Vereeniging van R.K. Gestichten en Inrichtingen (1940). Twaalfde jaarboek der Vereeniging van R.K. Gestichten en Inrichtingen, 33.

${ }^{305}$ R.K. Vereeniging Het Limburgsche Groene Kruis. Archief R.K. Vereeniging Het Limburgsche Groene Kruis, map 123.

Uit de advertentietekst waarmee voor de functie wordt geworven, blijkt dat de kandidate de diploma"s A (somatische verpleging), B (psychiatrische verpleging) en de wijkaantekening moet hebben. Ter voorbereiding loopt de verpleegkundige twee weken stage bij het consultatiebureau in Rotterdam.

${ }^{306}$ De cijfers zijn samengesteld aan de hand van de jaarverslagen van de R.K. Vereeniging Het Limburgsche Groene Kruis over de betreffende jaren.
} 
viteiten ten behoeve van kinderen, zowel de bezoeken aan de bureaus als de huisbezoeken, daalt. Het wel erg grote aantal huisbezoeken gebeurt tot 1946 per fiets, bus en trein. Vanaf dan is er de beschikking over een auto. ${ }^{307}$

Naast toezicht en controle op ontslagen patiënten zijn de huisbezoeken, zij het in kleinere omvang, ook bedoeld als voorbereiding op proefverlof en ontslag. Er wordt zogenoemd milieuonderzoek verricht om te bekijken of de voorwaarden voor terugkeer van de patiënt gunstig zijn. ${ }^{308}$ Over proefverlof, ontslag en eventuele heropname wordt overlegd tijdens de maandelijkse nazorgbijeenkomsten in de inrichtingen. De nazorgdiensten worden vertegenwoordigd door de psychiaters en de verpleegkundigen. De inrichtingen vinden na verloop van tijd de weg naar de nazorg, ook al is dat niet altijd om behandel-inhoudelijke overwegingen, maar bijvoorbeeld door plaatstgebrek. In 1954 worden door Sint Servatius 104 patiënten verwezen. ${ }^{309}$ In 1958 gaat het om 137 verwijzingen, waarvan er negentien weer teruggaan naar de inrichting. ${ }^{310}$

$\mathrm{Er}$ is overigens sprake van discrepantie tussen dat wat als wenselijk wordt beschouwd en de werkelijkheid van alledag. Het komt regelmatig voor dat er patiënten worden ontslagen zonder dat de nazorgdiensten daarvan tijdig op de hoogte zijn. Ook gebeurt het dat heropnames, noodzakelijk volgens de nazorgdienst, niet worden gerealiseerd. ${ }^{311}$

Anno 1959 zijn er in Limburg zes nazorgverpleegkundigen, ook districtszusters geheten, actief die meer dan 6200 huisbezoeken afleggen. In 1960 wordt er een psychiater aangesteld als hoofd van de provinciale voor- en nazorgdienst bij het Groene Kruis. ${ }^{312}$ Aan de hand van informatie uit de regio Maastricht kan een indruk worden gegeven van het vervolg van de ontwikkelingen.

\footnotetext{
${ }^{307}$ De aantallen huisbezoeken die door de verpleegkundigen worden afgelegd, zijn niet kenmerkend voor Limburg. Ook in Rotterdam en Amsterdam is dat het geval, zij het dat het daar gaat om een beduidend kleiner verzorgingsgebied.

Aantallen sociale bezoeken, ook wel bezoeken voor propagandistische doeleinden genoemd, zijn niet meegenomen omdat nadere informatie niet is gevonden.

${ }^{308}$ Verslag St. Servatius. In Vereeniging van R.K. Gestichten en Inrichtingen (1946). Dertiende Jaarboek der Vereniging van R.K. Gestichten en Inrichtingen, 12.

${ }^{309}$ Verslag St. Servatius. In Vereeniging van R.K. Gestichten en Inrichtingen (1954). Zeventiende Jaarboek van de Vereeniging van $R$ K. Gestichten en Inrichtingen, 16.

${ }^{310}$ Verslag St. Servatius. In Katholieke Vereniging voor Behandeling en Verpleging van Geestelijk Gestoorden (1958). Jaarboek van de Katholieke Vereniging voor Behandeling en Verpleging van Geestelijk Gestoorden.

${ }^{311}$ Deze informatie is afkomstig uit het statusonderzoek, waarover verderop in deze tekst wordt bericht, en uit interviews, gehouden met in die tijd actieve nazorgverpleegkundigen. Over deze interviews wordt elders bericht.

${ }^{312}$ Philips, J.F.R. 50 Jaar Limburgse Groene Kruis: 50 jaar sociale gezondheidszorg in Limburg: de R.K. Vereniging Het Limburgse Groene Kruis in het goud, 1910-1960, 220.
} 


\subsection{Sociale psychiatrie in de regio Maastricht}

Op 29 mei 1956 komt de Stichting Centrum Maastricht en omgeving voor Geestelijke Gezondheidszorg, later de Stichting Geestelijke Gezondheidszorg Maastricht en omgeving, tot stand. Ze stelt zich ten doel "de behartiging en bevordering van de geestelijke volksgezondheid in haar werkgebied, overeenkomstig de katholieke beginselen en ten bate van iedereen, zonder onderscheid om godsdienstige, maatschappelijke of politieke instelling; voor niet katholieken naar vermogen aangepast aan eigen levensbeschouwing en met bijstand van zielzorgers en deskundigen van eigen richting".313 In de stichting zijn ondergebracht het Medisch-Opvoedkundig Bureau, het Bureau voor Huwelijksaangelegenheden ook wel Bureau voor Leven(s)en Gezin(smoeilijkheden) genoemd en de Sociaal-Psychiatrische Dienst. De laatste is de voortzetting van de voor- en nazorgdienst.

In 1956 en 1957 worden er respectievelijk 1498 en 1473 huisbezoeken afgelegd. Er wordt bemiddeld bij het vinden en het behouden van werk, bij het vinden van nieuw en vervangend onderdak en er wordt geholpen bij het regelen van financiële hulp. Er worden contacten onderhouden met wijkverpleegkundigen en het plaatselijke charitatieve centrum. "Al deze contacten vragen echter veel tijd, waardoor het huisbezoek weer in het gedrang komt". ${ }^{314}$ De Sociaal-Psychiatrische Dienst is betrokken bij vijftien (her)opnames. Bij verschillende opgenomen patiënten wordt milieuonderzoek gedaan ter voorbereiding op proefverlof en ontslag.

In september 1958 wordt een tweede verpleegkundige aangesteld, die zich speciaal richt op de zorg voor patiënten van Calvariënberg, meer in het bijzonder met het opzetten van de gezinsverpleging. In 1961 treedt zij in dienst bij Calvariënberg. ${ }^{315}$ De psychiater van de Sociaal Psychiatrische Dienst werkt nog steeds parttime. De verpleegkundigen houden vanaf 1960 voor het eerst zelfstandig spreekuur, en zien dan meteen een aanzienlijk aantal patiënten: 485. In 1961 zijn het er 419. Ze leggen in die jaren respectievelijk 993 en 1270 huisbezoeken en 296 en 530 sociale bezoeken af. ${ }^{316}$

Even ziet het ernaar uit dat er een nieuwe beroepsgroep bij de sociale psychiatrie betrokken gaat worden. In 1962 wordt een maatschappelijk werkster aangesteld. Deze blijft echter maar anderhalf jaar. Blijkbaar heeft het ontbroken aan voorbereiding "waarbij een behoorlijke taakomschrijving werd geformeerd waar-

\footnotetext{
${ }^{313}$ Stichting Centrum Maastricht en omgeving voor de Geestelijke Gezondheidszorg (1956). Jaarverslag 1956 (1). In R.K. Vereeniging Het Limburgsche Groene Kruis (1955). Jaarverslag R. K. Vereeniging Het Limburgsche Groene Kruis.

${ }^{314}$ R.K. Vereeniging Het Limburgsche Groene Kruis (1956). Jaarverslag R.K. Vereeniging Het Limburgsche Groene Kruis, 20.

${ }^{315}$ Persoonlijke mededeling P. Boren-Scholtes, maart 2002.

${ }^{316}$ Stichting Geestelijke Gezondheidszorg Maastricht e.o. (1961). Jaarverslag Stichting Geestelijke Gezondheidszorg Maastricht e.o. 1960-1961, 14
} 
mede én het bestaande team én de betreffende nieuwe kracht zich konden verenigen". 317

In het tekort aan psychiaters wordt gedeeltelijk voorzien door de al genoemde leider van de provinciale nazorgdienst en door twee interim-psychiaters, gedetacheerd vanuit Calvariënberg. ${ }^{318}$ Pas in 1965 zal er een fulltime psychiater in dienst komen. Naast het verrichten van direct patiëntgebonden activiteiten is de Sociaal Psychiatrische Dienst op de een of andere manier betrokken bij de Stichting Bijzondere Sociale Zorg, de kinderbescherming, de BLO-nazorg, de reclassering en het jongensinternaat in Heer. De dienst werkt ook mee aan de totstandkoming van een LOM-school. De Stichting GGZ Maastricht en omgeving heeft in 1967 een fulltime psychiater en drie verpleegkundigen in dienst.

Met de groei van het aantal personeelsleden neemt het aantal patiënten in voorzorg toe en groeit in die groep het aantal adolescenten, jong volwassenen en mensen met minder ernstige psychopathologie. Maar ook de nazorgpopulatie is aan het veranderen. Onder meer door de beschikbaarheid van effectievere medicijnen zijn langdurige opnames steeds minder noodzakelijk. Een groot deel van de ontslagen patiënten is laaggeschoold en werkloos; arbeidsbemiddeling en het vinden van huisvesting verlopen moeizaam. ${ }^{319}$ Deze groep wordt ook wel aangeduid met de term draaideurpatiënten. Er ontstaat behoefte aan bijzondere woonvormen, beschutte pensions genaamd. Samenwerking met een goed geoutilleerde psychiatrische polikliniek, waar een begin kan worden gemaakt met resocialisatie, wordt gemist.

In 1972 zijn in de regio Maastricht zes sociaalpsychiatrisch verpleegkundigen werkzaam, twee sociaalpsychiaters en twee psychologen, voor zover bekend allen fulltime. ${ }^{320}$ Met de komst van de psychologen komt er ook hier een einde aan het monopolie van de verpleegkundigen en de psychiaters en wordt er, net zoals elders in het land, een begin gemaakt met een actievere, meer psychotherapeutisch georienteerde werkwijze van de sociaalpsychiatrische diensten.

Inmiddels zijn in 1960 regionale Stichtingen voor Geestelijke Gezondheidszorg in Heerlen, Sittard, Roermond, Venlo en Weert opgericht. De functie van provinciaal nazorgpsychiater is overbodig geworden en vervalt in 1965. Met de regionalisering wordt in Limburg vooruitgelopen op de vorming van Regionale Instellingen voor Ambulante Geestelijke Gezondheidszorg, de Riagg's, die in 1982 landelijk wordt geeffectueerd.

\footnotetext{
${ }^{317}$ Stichting Geestelijke Gezondheidszorg Maastricht e.o. (1963). Jaarverslag Stichting Geestelijke Gezondheidszorg Maastricht e.o. 1962-1963, 5.

${ }^{318}$ Ibidem, 10.

${ }^{319}$ Stichting Geestelijke Gezondheidszorg Maastricht e.o. (1967). Jaarverslag Stichting Geestelijke Gezondheidszorg Maastricht e.o. 1964-1967, 35.

${ }^{320}$ Stichting Geestelijke Gezondheidszorg Maastricht e.o. (1972). Jaarverslag Stichting Geestelijke Gezondheidszorg Maastricht e.o. 1968-1972, 66-67.
} 


\subsection{Statusonderzoek}

Met dit statusonderzoek wordt beoogd inzicht te krijgen in de vragen of er sprake is van contacten tussen de inrichting enerzijds en personen en instanties extramuraal anderzijds, wat de omvang ervan is, om welke personen en instanties het gaat en wat de inhoud van die contacten is. Onderzocht wordt ook of en in hoeverre de antwoorden op de vragen in de loop van de jaren veranderen en met name of en in hoeverre ontwikkelingen en gebeurtenissen in de nazorg daarbij een rol spelen.

Voor zover bekend bestaan er geen statussen van de voor- en nazorgdiensten. Een andere informatiebron vormen de statussen van inrichtingspatiënten. Uit de periode die aan de orde is, zijn patiëntstatussen onderzocht van de voormalige inrichtingen Sint Servatius en Sint Anna te Venray. Het hierna gepresenteerde materiaal is dus beperkt tot wat er in de inrichtingsstatussen is gevonden. Er zijn statussen getrokken uit de jaren 1938, 1943, 1948, 1953, 1958, 1963, 1968 en 1973. De jaartallen geven het jaar aan waarin (her)opname is gerealiseerd. Daar het onderzoek is gericht op nazorg, zijn alleen statussen van patiënten die binnen drie jaar vanaf (her)opnamedatum met proefverlof of ontslag zijn gegaan, onderzocht. ${ }^{321}$ Van de genoemde jaren zijn in een eerste trekking statussen opgehaald van tien vrijwillig en tien onvrijwillig opgenomen mannen en van tien vrijwillig en tien onvrijwillig opgenomen vrouwen, in totaal veertig per jaar. Van het jaar 1943 zijn er in de categorie "vrouwen vrijwillig" slechts acht statussen gevonden, vallende binnen het gestelde criterium van ontslag binnen drie jaar na (her)opname. Het aantal statussen komt daarmee op 318.

\subsubsection{Aantallen contacten}

Tabel 1 geeft een overzicht in procenten van statussen waarin informatie is gevonden over contacten buiten de inrichtingen. Opvallend is de sterke stijging in het totale aantal contacten vanaf 1958. Over de hele periode is het aantal contacten bij vrouwen iets groter dan bij mannen en in de categorie onvrijwillig opgenomen groter dan in de categorie vrijwillig opgenomen.

\footnotetext{
${ }^{321}$ Als gevolg van de toegepaste werkwijze is informatie over patiënten die langer dan drie jaar ononderbroken zijn opgenomen, niet meegenomen.

Van onderzoek naar statussen van de voormalige inrichting Calvariënberg, ondergebracht in het PsychoMedisch Streekcentrum Vijverdal te Maastricht, is afgezien vanwege de beperkte toegankelijkheid ervan. De archieven, met daarin patiëntstatussen van Sint Servatius en Sint Anna, ondergebracht in het SociaalHistorisch Centrum voor Limburg in Maastricht, zijn toegankelijk. Statussen van recenter datum dan 1973 zijn, uit het oogpunt van privacy, niet in het archief ondergebracht.
} 
Tabel 1: percentages contacten buiten de inrichting in statussen van 318 patiënten, 1938-1973, 40 per jaar, uitgezonderd 38 in 1943, naar geslacht en juridische status van opname

\begin{tabular}{lccccc}
\hline jaar & man & vrouw & onvrijwillig & vrijwillig & totaal \\
\hline 1938 & 70 & 55 & 70 & 55 & 62 \\
1943 & 60 & 39 & 60 & 39 & 50 \\
1948 & 65 & 45 & 65 & 45 & 55 \\
1953 & 35 & 85 & 65 & 25 & 45 \\
1958 & 45 & 65 & 45 & 65 & 55 \\
1963 & 85 & 85 & 90 & 80 & 85 \\
1968 & 90 & 75 & 80 & 80 & 83 \\
1973 & 70 & 75 & 80 & 65 & 72 \\
totaal & 65 & 69 & 70 & 57 & 64 \\
\hline
\end{tabular}

\subsubsection{Soorten contacten}

In tabel 2 zijn de aanwijzingen voor contacten uitgesplitst naar soorten, te weten: familie, huisarts, zenuwarts, maatschappelijk werk, nazorginstantie, autoriteiten (wereldlijk en kerkelijk) en overigen. In alle gevallen is er sprake van contacten in meer dan één categorie. Dat verklaart waarom de percentages in de kolom "totaal" groter zijn dan 100 .

Tabel 2: percentages contacten naar soort contact voor alle patiënten met contacten naar jaar, 318 patienten. fam=familie, ha=huisarts, $z a=z e n u w a r t s, ~ m w=m a a t s c h a p p e l i j k$ werk, aut=autoriteiten (wereldlijk en kerkelijk), ov=overige

\begin{tabular}{lrrrrrrrr}
\hline jaar & fam & ha & za & mw & nazorg & aut & ov & totaal \\
\hline 1938 & 84 & 8 & 0 & 0 & 0 & 12 & 16 & 120 \\
1943 & 74 & 16 & 0 & 5 & 21 & 0 & 11 & 126 \\
1948 & 59 & 5 & 14 & 5 & 9 & 8 & 9 & 109 \\
1953 & 89 & 17 & 0 & 11 & 6 & 0 & 6 & 128 \\
1958 & 45 & 36 & 0 & 0 & 45 & 0 & 9 & 136 \\
1963 & 24 & 56 & 18 & 6 & 100 & 0 & 9 & 212 \\
1968 & 27 & 67 & 12 & 6 & 82 & 6 & 21 & 221 \\
1973 & 17 & 55 & 21 & 14 & 86 & 0 & 10 & 203 \\
$1938 / 73$ & 48 & 37 & 9 & 6 & 51 & 3 & 12 & 165 \\
$1938 / 53$ & 65 & 11 & 4 & 5 & 8 & 6 & 11 & 120 \\
$1958 / 73$ & 27 & 55 & 14 & 7 & 85 & 2 & 13 & 198 \\
\hline
\end{tabular}

In 1938 gaat het in 84 procent van de gevallen waarbij contacten buiten de inrichting zijn gevonden, om familie. Dat aantal daalt daarna gestaag, met een uitschieter 
naar boven in 1953. Aantallen contacten in andere categorieën, met uitzondering van de verzamelcategorie overigen, zijn met praktisch één op tien of met nul beduidend lager. Vanaf 1958 stijgt het aantal contacten in meer dan één categorie sterk. Dat is vooral toe te schrijven aan de stijging in de categorieën nazorg, huisarts en, in mindere mate, in de categorie zenuwarts. Contacten met maatschappelijk werk zijn er over de hele periode weinig tot niet, met uitzondering van 1953 en 1973. Absoluut komt dat, afgerond naar boven, neer op twee respectievelijk vijf gevallen.

Voor de stijging in de categorie nazorg kunnen twee verklaringen worden gegeven. De eerste is dat de nazorg regulier deel begint uit te maken van de zorg. Dat kan worden opgemaakt uit de al vermelde toename van het aantal verpleegkundigen tot zes in 1959. De tweede verklaring zou de komst van de provinciale nazorgpsychiater in 1960 kunnen zijn.

Om die hypothese te toetsen is een tweede trekking uitgevoerd. Er zijn van de jaren 1954 tot en met 1957 en van 1959 tot en met 1962 telkens acht statussen getrokken, twee voor vrijwillig en twee voor onvrijwillig (her)opgenomen mannen en vrouwen, samengevoegd tot zestien per twee jaar. Daaruit wordt duidelijk dat de grote stijging in het aantal contacten met de nazorg inderdaad begint na de komst van de provinciale nazorgpsychiater in 1960 . Het percentage vermelde contacten met de nazorg stijgt van 56 in 1959/1960 tot 100 in 1963. De inrichtingspsychiaters hebben in de persoon van de nazorgpsychiater blijkbaar een instantie waaraan ze hun berichten kunnen adresseren.

Het percentage contacten algemeen neemt toe van 75 tot 85 . Ook het aantal contacten per contactgeval stijgt: van 1,4 tot 2,1 . Met deze toenames voltrekt zich een daling in het percentage contacten met familie, en wel van 56 in 1959/1960 tot 24 in 1963. De conclusie kan worden getrokken dat met de komst van de nazorgpsychiater de rol van de familie als contactinstantie van de inrichtingspsychiaters afneemt, en dat de frequentie van de contacten in de overige categorieën toeneemt. Het is de vraag of de komst van de nazorgpsychiater en de afname van de contacten tussen inrichtingspsychiater en familie verband met elkaar houden en of de hypothese voor de hand ligt dat de nazorg die contacten overneemt.

\subsubsection{Inhoud van de contacten}

De contacten tussen inrichtingspsychiaters en familie zijn van velerlei aard. De psychiaters vragen aan de familie om informatie over de patiënt en zijn leef-, woon- en werkomstandigheden. Omgekeerd worden er ook vragen gesteld aan de psychiater, onder meer over de toestand van de patiënt, hoe lang de opname nog zal duren, of er verlof kan worden geregeld, of wordt er meegedeeld dat de familie alles in het werk wil stellen om de patiënt weer thuis te kunnen hebben, dat er zal worden gezorgd voor bezigheden of dat de werkgever de patiënt weer een werkplek wil bieden. De vragen en opmerkingen getuigen niet altijd van evenveel welwillendheid 
ten opzichte van de patiënt, zoals blijkt uit verschillende brieven van een vrouw die de behandelaar onder meer vraagt om haar man "maar eens goed onder handen te nemen, b.v. met spuiten... Rusten alleen zal wel niet helpen". ${ }^{322}$

Een enkele keer beklaagt de familie zich over de gang van zaken in de inrichting, bijvoorbeeld dat de patiënt als proefkonijn wordt gebruikt of dat het verplegend personeel niet deskundig is. Dankzeggingen aan de psychiater voor de goede behandeling van het familielid, waarin soms ook het verplegend personeel wordt betrokken, komen vaker voor.

Een paar keer is een bedankje gevonden van ontslagen patiënten. Soms schrijven patiënten hoe het hun na het ontslag is vergaan. Een patiënt schrijft tijdens het proefverlof dat hij verkering heeft en vraagt naar de mening van de psychiater over zijn trouwplannen. De psychiater meent dat het verstandiger is "even af te wachten of uw toestand goed blijft. Daarom is het beter dat u met verkering en trouwen minstens een aantal jaren wacht". ${ }^{323}$

Een overste van een klooster vraagt per brief aan de geneesheer-directeur van St. Anna of het verantwoord is om de dochter van de vrouw die onder behandeling is, in de orde te laten intreden. De reactie luidt dat moeder en grootmoeder bekend zijn met psychiatrische verschijnselen en een tante van moederszijde met krankzinnigheid. "Het enige wat het voorgaande mij in casu zegt, is dat bijzondere voorzichtigheid in acht moet worden genomen... Deze voorzichtigheid vraagt m.i. niet zonder meer afwijzen, wel nader onderzoek door een psychiater". ${ }^{324}$

In de brief van een psychiater aan de huwelijkskandidaat van een patiënte wordt vastgesteld dat "een samentrekking van twee gezinnen met elf en vijf kinderen objectief onmogelijk is". De psychiater verzoekt de man, namens patiënte, niet meer op bezoek te komen. In een brief wordt dat toegezegd. ${ }^{325}$

Van geheel andere, zakelijke aard, zijn de ontslagbrieven en aankondigingen van proefverlof, gericht aan de nazorgdienst c.q. de sociaal psychiater. De brieven gaan ook naar huisartsen en, in mindere mate, naar zenuwartsen. Het gaat bijna altijd om zenuwartsen verbonden aan ziekenhuizen, zelden om vrijgevestigde. De inhoud van de ontslagbrieven is min of meer standaard: reden voor opname, verloop van de opname, soms een psychiatrische diagnose, soms een mededeling omtrent gebruikte medicatie en het advies om deze voort te zetten. Zelden tot nooit wordt er geadviseerd over verdere behandeling. Indien dat wel gebeurt gaat het niet veel verder dan de opmerking dat nazorg dringend is geïndiceerd of dat toezicht door de verpleegkundige bij de inname van medicijnen door een alcoholist gewenst is.

\footnotetext{
${ }^{322}$ SHCL. Archief St. Servatius 1958, status 1066.

${ }^{323}$ Ibidem, 1943, status 4755.

${ }^{324}$ SHCL. Archief St. Anna 1953, status 1425.

${ }^{325}$ Ibidem, 1968, status 6367.
} 
Er zijn nauwelijks aanwijzingen voor samenwerking tussen inrichting en nazorgdienst, anders dan het voorbereiden van proefverlof en ontslag. Een uitzondering is de vraag van een inrichtingspsychiater aan een verpleegkundige om eens poolshoogte te nemen tijdens een verlof, (niet te verwarren met het proefverlof van een patiënt die met machtiging is opgenomen), om informatie te verstrekken over de leefomstandigheden van de patiënt in kwestie. "Gaarne zie ik dus aan het eind van de tweede week uw bericht tegemoet". ${ }^{326}$

Concrete activiteiten van de verpleegkundigen komen bijna zonder uitzondering neer op toezicht/controle, informatie verzamelen ten behoeve van de inrichtingsen de sociaalpsychiater, het regelen van ontslagvoorwaarden zoals huisvesting en het informeren/instrueren van de omgeving van de patiënt. De berichtgeving van de verpleegkundigen doet er blijkbaar toe. Gunstige berichten over de patiënt en diens omgeving kunnen leiden tot proefverlof of ontslag. ${ }^{327}$ De verpleegkundigen schrijven, zeker in latere jaren, regelmatig sociale rapporten. Daarin komen veel en verscheiden aspecten van het leven van de patiënt en diens omgeving aan de orde. Uit aantekeningen van een inrichtingspsychiater blijkt dat een zeer gedetailleerd rapport van een verpleegkundige over onder meer het seksuele gedrag van een patiënte bijna integraal in de medische status wordt overgenomen. ${ }^{328}$ Uit 1973 stammen brieven waarin verpleegkundigen om opname van patiënten verzoeken en over de condities waaronder, dat wil zeggen met of zonder Rechterlijke Machtiging. ${ }^{329}$ Uit het schrijven van dit soort brieven kan worden opgemaakt dat er iets aan het veranderen is in de rol die de verpleegkundigen hebben, zowel ten opzichte van de inrichtingspsychiaters als binnen de sociaalpsychiatrische diensten.

Een enkele keer blijkt dat activiteiten van de verpleegkundigen én van de psychiaters op wel erg praktische, maar daarom niet onbelangrijke zaken gericht zijn. Zo is er correspondentie tussen een verpleegkundige en de geneesheer-directeur van Sint Anna over een kunstgebit dat tijdens de opname van een patiënte verloren is gegaan. De verpleegkundige kan op rekening van Sint Anna een nieuw gebit regelen. ${ }^{330}$

\subsection{Conclusies en discussie}

In de provincie Limburg ontstaat in de tweede helft van de jaren dertig van de twintigste eeuw aarzelend het domein van de sociale psychiatrie. Aanvankelijk maken met name kinderen en kleinere aantallen volwassen niet-inrichtingspatiënten er gebruik van. Nazorg is nauwelijks aan de orde. Psychiaters houden spreekuur, een verpleegkundige assisteert en legt incidenteel huisbezoeken af.

\footnotetext{
${ }^{326}$ Ibidem, 1963, status 2271.

${ }^{327}$ Ibidem, status 6108; 1968, status 6373 .

${ }^{328}$ Ibidem, status 6367.

${ }^{329}$ Ibidem ,1973, status 6573, status 6575, status 10. 2985.

${ }^{330}$ Ibidem,1968, status 2852.
} 
Vanaf 1940 zet de groei in. Die hangt samen met de komst van de fulltime provinciale huisbezoekster. De grote aantallen huisbezoeken van de verpleegkundige zijn met name gericht op (ex)-inrichtingspatiënten, en daarmee op nazorg. Met de komst van meer verpleegkundigen na de Tweede Wereldoorlog zet de groei door. Het aantal psychiaters blijft tot de tweede helft van de jaren zestig laag. Hun activiteiten beperken zich voornamelijk tot het houden van spreekuren.

Aan het eind van de jaren vijftig ontstaat er een duidelijke toename van het aantal contacten tussen inrichting enerzijds en de nazorg anderzijds. Die toename hangt samen met de komst van de provinciale nazorgpsychiater in 1960 en kan voor een beduidend deel worden toegeschreven aan brieven met aankondiging van proefverlof en ontslag. Tegelijk met voornoemde groei daalt de hoeveelheid contacten van inrichtingspsychiaters met familie van de patiënten.

De positie van de inrichtingspsychiater blijft door de jaren van gewicht. De echte psychiatrie speelt zich af in de inrichting; de sociale psychiatrie blijft lange tijd een afgeleide van de inrichtingspsychiatrie. Sociale psychiatrie berust in hoge mate op ervaring en inzicht en is in wezen een vorm van maatschappelijke dienstverlening.

De rol van de nazorgverpleegkundigen is zeer belangrijk. Zij zijn het die de patienten bezoeken en controleren en die patiënten zien en informatie verstrekken aan de psychiaters. Die informatie speelt een doorslaggevende rol bij de besluitvorming rond proefverlof, ontslag en heropname. De verpleegkundigen zijn van belang voor het functioneren van de nazorg. Zonder verpleegkundigen is er van nazorg en sociale psychiatrie geen sprake.

Met de regionalisering vanaf 1956 wordt de extramurale geestelijke gezondheidszorg grondig gereorganiseerd. Limburg loopt daarmee vooruit op de Riaggvorming die in 1982 landelijk wordt geëffectueerd.

Omstreeks 1970 dient zich het einde aan van een betrekkelijk stabiel tijdperk. In de nazorgpopulatie groeit de groep die kan worden omschreven als jonge chronici. Het zijn patiënten die intensieve begeleiding behoeven. Het aantal voorzorgcontacten neemt toe en daarmee dient zich een nieuw type patiënt aan met andere problemen en vragen. Met de komst van psychologen maakt in Limburg een nieuwe beroepsgroep zijn opwachting, die duidelijk anders is opgeleid en georiënteerd dan de verpleegkundigen en de psychiaters. De nazorg in Limburg, goed dertig jaar oud, heeft in haar bekende vorm de langste tijd gehad.

In hoeverre komen de ontwikkelingen in Limburg overeen of wijken ze af van de ontwikkelingen elders in Nederland, zoals weergegeven in hoofdstuk 3 en 5 ?

Vooropgesteld moet worden dat het in dit verband moeilijk is om te spreken van "elders in Nederland". Er zijn aanzienlijke verschillen tussen steden en provincies, en er zijn weer verschillen tussen steden onderling en tussen provincies onderling. 
Dat gezegd hebbende kan worden geconcludeerd dat de ontwikkelingen in de sociale psychiatrie in Limburg in grote lijnen niet verschillen van de ontwikkelingen elders, behalve dat ze later beginnen en lange tijd langzamer verlopen. Daarvoor kunnen verschillende verklaringen worden gegeven.

Met name in de snel groeiende steden is wat tegenwoordig wel de grotestedenproblematiek wordt genoemd, omvangrijk en zichtbaar. Dat maakt het nemen van initiatieven op het gebied van de geestelijke hygiëne en van de voor- en de nazorg vooral daar urgent. Met een beduidend homogenere bevolkingsopbouw en veelal op religieuze grondslag functionerende maatschappelijke verbanden is de problematiek in Limburg in die tijd minder actueel.

De steden hebben een stevige regiefunctie die bijdraagt aan de succesvolle start van de sociale psychiatrie. Rotterdam heeft met zijn "stadsinrichting" Maasoord maar één partner waarmee zaken moeten worden gedaan. In Amsterdam wordt elke patiënt bij wie opname wordt overwogen, bij de GG\&GD aangemeld en gescreend. Waar mogelijk worden opnamevoorkomende maatregelen genomen. In Limburg, en ook in andere provincies, is dat nauwelijks het geval. Er is geen instantie die een vuist kan maken.

Ook hebben de grote steden een direct merkbaar financieel belang bij opnamepreventie en -verkorting. Amsterdam bijvoorbeeld bekostigt begin jaren dertig de opname van zo'n 3000 burgers en is gebaat bij kostenreductie. Voor de relatief kleine gemeentes in de provincie is dat belang minder groot. Als gevolg daarvan draagt niemand de kosten die gepaard gaan met een goed opgezette voor- en nazorg. Het Groene Kruis is daartoe in Limburg niet in staat. De provincie draagt in 1939 een onbekend bedrag bij, waardoor waarschijnlijk de verpleegkundige in 1940 kan worden aangesteld en de psychiaters van de verschillende consultatiebureaus kunnen worden betaald. In Noord-Brabant daarentegen subsidieert de provincie al in 1936 de Provinciale Dienst voor Geestelijke Volksgezondheid met een bedrag van $f$ 16.000, gekort op de subsidie aan instellingen. ${ }^{331}$ Het Limburgse Groene Kruis draagt uit de contributiegelden vanaf 1954 f 0,85, vanaf 1957 f 1,50 per lid per jaar bij aan de kosten van de psychiatrische voor- en nazorg. In 1957 besluit het provinciebestuur een toeslag op de verpleegprijs van opgenomen patiënten van $f 0,30$ per verpleegdag te heffen, die ten goede komt aan de voor- en nazorg. In 1960 wordt de zogenaamde " 30 cent-bijdrage" vervangen door een nieuwe provinciale subsidie. ${ }^{332}$ De financiering vormt jaren een belemmering voor de ontwikkeling van de sociale psychiatrie in Limburg. Dat is elders buiten de grote steden ook het geval. ${ }^{333}$ Voor

\footnotetext{
${ }^{331}$ Westhoff, H. (1996). Geestelijke bevrijders: Nederlandse katholieken en hun beweging voor geestelijke gezondheidszorg in de twintigste eeuw. Nijmegen: Valkhof Pers, 71.

${ }^{332}$ Philips, J.F.R. 50 Jaar Limburgse Groene Kruis: 50 jaar sociale gezondheidszorg in Limburg: de R.K. Vereniging Het Limburgse Groene Kruis in het goud, 1910-1960, 213.

Hoe hoog die subsidie is, is in de bron niet vermeld.

${ }^{333}$ Grinten, T.E.D. van der. De vorming van de ambulante geestelijke gezondheidszorg: een historisch beleidsonderzoek, 174.
} 
een deel komt daarin verandering met de rijkssubsidieregeling van 1961, maar vooral in 1971 als de financiering wordt geregeld via de AWBZ.

Samenhangend met de financiën kan het voortdurende tekort aan psychiatrische mankracht als een volgende oorzaak van de trage ontwikkeling in Limburg worden gezien. Deels kan dat tekort echter ook worden verklaard uit de lage status die de sociale psychiatrie heeft, waardoor het moeilijk is om psychiaters aan te trekken, deels uit het algemene tekort aan psychiaters, al dan niet met een katholieke achtergrond. In Sint Servatius komt pas in 1957 de eerste zenuwarts in dienst. Tot dan toe werken er artsen met psychiatrische ervaring. ${ }^{334}$

De houding van de inrichtingen is een belangrijke verklaring voor de relatief late start van de nazorg. Gebleken is dat de directie van Sint Anna de nazorg vanuit de inrichtingen niet bepaald heeft gestimuleerd. Van de directie van Sint Servatius wordt in de beginperiode niets gehoord. De nazorg wordt in handen van het Groene Kruis gegeven. Bij de voorbereidingen in de Commissie voor Geestelijke Volksgezondheid spelen de beide inrichtingen een belangrijke rol. De niet voor de nazorg geporteerde geneesheer-directeur van Sint Anna is jarenlang voorzitter van de commissie. Ook het gegeven dat er aanvankelijk vanuit de inrichtingen zo weinig patiënten naar de nazorg worden verwezen kan worden gezien als uiting van een weinig enthousiaste opstelling. Die opstelling verklaart mogelijk ook waarom er in Limburg geen "sterke figuren" zijn opgestaan, hetgeen elders met personen zoals Meijers en Querido in Amsterdam, Pameyer in Rotterdam en Kortenhorst in NoordBrabant wel het geval is.

Er kan een vraag worden gesteld naar de invloed van de Rooms Katholieke Kerk, die in Limburg in die tijd groot is. De geestelijkheid heeft een rol in het bestuur van het Provinciale Groene Kruis en maakt zich daar herhaaldelijk sterk voor de geestelijke gezondheid in de provincie. ${ }^{335}$ Niet duidelijk is of er rechtstreekse invloed van de kerk is op de ontwikkeling van de sociale psychiatrie in Limburg en zo ja, of die verband houdt met de relatief late start en de trage ontwikkeling ervan. In NoordBrabant, waar de kerk ook een sterke rol heeft, is dat laatste, zoals uit het voorbeeld van Breda en omstreken laat zien, blijkbaar niet het geval.

Een bijzondere ontwikkeling in Limburg is de regionalisering die al in 1960 haar beslag krijgt met de oprichting van stichtingen voor geestelijke gezondheidszorg in Venlo, Roermond, Weert, Sittard en Heerlen. Vanaf begin jaren vijftig zijn de katholieke activiteiten op het terrein van de geestelijke gezondheidszorg landelijk gebundeld in het Katholiek Nationaal Bureau voor Geestelijke Gezondheidszorg. Dat bureau beijvert zich om te komen tot katholieke organisatorische verbanden op het gebied van de geestelijke gezondheidszorg. In het betrekkelijk homogene Limburg,

\footnotetext{
${ }^{334}$ Billekens, A.J., Boeck, L. de, Els, T. van, Jaarsveld, T. van, Jansen, P., Kroft, A., Lucassen, G., Marlet, J. en Vriens, H. (2005). 100 Jaar psychiatrie in Venray: geschiedenis van de psychiatrische instellingen Sint Anna en Sint Servatius. Zutphen: Walburg Pers, 136.

${ }^{335}$ Philips, J.F.R. 50 Jaar Limburgse Groene Kruis: 50 jaar sociale gezondheidszorg in Limburg: de R.K. Vereniging Het Limburgse Groene Kruis in het goud, 1910-1960, 208.
} 
waarin geen dominante gemeentes zijn, en waarin twee katholieke inrichtingen en het katholieke Groene Kruis een grote rol spelen, vindt dat streven navolging. Er komt in de institutionele leegte, ofschoon niet zonder slag of stoot, relatief gemakkelijk een moderne infrastructuur voor extramurale geestelijke gezondheidszorg tot stand. Als daarna het proces van secularisatie op gang komt en de rol van kerk en religie minder prominent wordt, blijft de regionale infrastructuur overeind. De extramurale geestelijke gezondheidszorg in Limburg loopt vanaf dan jarenlang vooruit op de ontwikkelingen elders in Nederland. 


\section{Hoofdstuk 7}

\section{Sociaalpsychiatrisch verpleegkundigen en de beroepsontwikkeling in de periode van omstreeks 1950 tot omstreeks 1985}

\subsection{Inleiding}

Voor zover de ontwikkeling van de sociaalpsychiatrische verpleegkunde tot nu toe in dit onderzoek aan de orde is gekomen, is dat voornamelijk gebeurd op basis van informatie die niet rechtstreeks afkomstig is van verpleegkundigen zelf. Het gaat om indirecte informatie, die afkomstig is uit literatuur, jaarverslagen en patiëntstatussen.

Een relevante gegevensbron, de verpleegkundigen, is daarmee tot nu toe onbenut gebleven. Die bron is van belang om een zo volledig mogelijk beeld te krijgen van het domein van de sociaalpsychiatrische verpleegkunde, van de werkzaamheden die de verpleegkundigen op hun domein verrichten, van de manier waarop ze aan die werkzaamheden vorm en inhoud geven en van veranderingen op genoemde terreinen. Met informatie uit die bron kan de beantwoording van de tweede vraag van deze studie, die luidt: hoe heeft zich in het domein van de sociale psychiatrie de verpleegkundige beroepsgroep ontwikkeld, verder worden uitgediept.

In dit hoofdstuk wordt geschetst hoe de sociaalpsychiatrisch-verpleegkundige beroepsontwikkeling zich in de periode van omstreeks 1950 tot ongeveer 1985 heeft voltrokken vanuit het perspectief van de verpleegkundigen. Er zal antwoord worden gegeven op de vragen: voor welke patiënten zijn de verpleegkundigen actief; wat doen ze concreet voor die patiënten; met welke professionals en instellingen werken ze samen en hoe verloopt die samenwerking; hoe zijn ze opgeleid of anders gezegd, over welke kennis en vaardigheden beschikken ze; vinden ze dat ze voldoende zijn toegerust voor hun taken; wat is de betekenis van de veranderingen die zich in de loop van de jaren voltrekken in de geestelijke gezondheidszorg en, ten slotte, vanuit welke achtergronden en opvattingen werken ze en met welke bedoelingen? Aan het einde van dit hoofdstuk wordt de verkregen informatie besproken in termen van de in hoofdstuk 1 beschreven dimensies van Benson, te weten ideologische en domeinconsensus, werkcoördinatie en positieve evaluatie, zowel binnen de verpleegkundige professie als tussen de verpleegkundige en andere professies die in het domein van de sociale psychiatrie actief zijn. 
Zoals zal blijken zijn de verpleegkundigen tot omstreeks 1970 op het tot dan toe redelijk stabiele domein van de sociale psychiatrie, samen met de psychiaters, de centrale actoren. Ze werken met een hoge mate van autonomie, eerst enkel in de vorm van nazorg, later ook van voorzorg, aan het faciliteren van het verblijf van psychiatrische patiënten buiten de inrichting. Ze doen dat vooral door het afleggen van grote aantallen huisbezoeken en het assisteren van de psychiaters tijdens de spreekuren. Ofschoon de verpleegkundigen breed zijn opgeleid, is die opleiding nauwelijks afgestemd op de aard van het werk.

In de loop van de jaren zestig gaan zich veranderingen aftekenen. Met de komst van psychologen is de hegemonie van verpleegkundigen en psychiaters verleden tijd. Het accent van de sociale psychiatrie als werkveld verschuift van generieke begeleiding van patiënten met psychiatrische problemen, al dan niet maatschappelijk onaangepast, naar psychotherapeutische behandeling van mensen met psychosociale problemen. De verpleegkundigen gaan deels mee in de ontwikkelingen en beginnen zich langzaam aan bij te scholen.

De komst van de Riagg's in 1982 is in alle opzichten een markeringspunt. In de relatief grote en bureaucratische Riagg's raakt de autonomie van de verpleegkundigen in de verdrukking. Behandeling met nadruk op psychotherapie komt steeds meer in de belangstelling te staan. De begeleiding van de oorspronkelijke voor- en nazorgpatiënten raakt sterk op de achtergrond.

Binnen de verpleegkundige beroepsgroep treedt een zekere mate van divergentie op. Er is een groep die van mening is dat voor- en nazorg "oude stijl" de kern van het taakgebied is, en er is een groep die zich meer gaat richten op de nieuwe cliënten en op de daarvoor in aanmerking komende nieuwe therapeutische werkwijzen. Die divergentie blijft niet beperkt tot de groep oudere verpleegkundigen, maar is ook zichtbaar bij de groep die vanaf 1974 uitstroomt uit de nieuwe beroepsopleiding.

\subsection{Bronnen}

De informatie die voor dit hoofdstuk wordt gebruikt is afkomstig uit verschillende bronnen.

De eerste bron bestaat uit interviews die ten behoeve van deze studie zijn gehouden met acht gepensioneerde sociaalpsychiatrisch verpleegkundigen, allen vrouw. Ze zijn geboren tussen 1925 en 1942 en vanaf omstreeks 1960 actief geweest in de sociale psychiatrie. Ze hebben alle acht de overgang naar de Riagg's, begin jaren tachtig, meegemaakt. De vrouwen zijn in verschillende werkvelden actief geweest: in de jeugdpsychiatrie, de volwassenen- en de bejaardenzorg. Ze hebben gewerkt bij GG\&GD's in de Randstad, bij provinciale en regionale nazorgdiensten en bij psychiatrische ziekenhuizen, één aanvankelijk bij de nazorgdienst, een ander bij de gezinsverpleging. Allen hebben ze als opleiding de A, de B, de wijkaan- 
tekening en de B-nazorg. Drie hebben de kraamaantekening, twee de kaderopleiding, één de Voortgezette Opleiding-SPV en twee hebben andere opleidingen gevolgd, te weten een gestaltcursus en een cursus systeemtherapie. Eén respondent heeft een psychoanalytische leertherapie gedaan. Een ander die als maatschappelijk werkende is begonnen, heeft later de A, de B, de wijk en de B-nazorg gedaan. Geen van de geïnterviewden heeft de opleiding MGZ/GGZ, die in 1972 van start is gegaan, gevolgd. ${ }^{336}$ De informatie die van deze groep afkomstig is, is herkenbaar aan de verwijzingen tussen haakjes (. .) na de citaten.

De tweede bron bestaat uit gesprekken met sociaalpsychiatrisch verpleegkundigen zoals weergegeven in "Thuis opgenomen: uit de geschiedenis van de sociale psychiatrie in Nederland". ${ }^{337}$ De oudsten van deze groep zijn beroepsmatig actief vanaf eind jaren veertig, begin jaren vijftig.

De derde bron is de informatie van verpleegkundigen zoals verwoord in "Hoopvol bezorgd: sociaalpsychiatrische verpleegkunde van de $20^{\mathrm{e}}$ naar de $21^{\mathrm{e}}$ eeuw". ${ }^{338}$ De informatie beslaat twee groepen. De eerste groep komt in leeftijd overeen met de groep van acht die ten behoeve van deze studie is geïnterviewd. ${ }^{339}$ De tweede groep bestaat uit vertegenwoordigers van de generatie verpleegkundigen die rond 1950 is geboren. Zij hebben de nieuwe opleiding MGZ/GGZ gedaan, de eerste in 1974, de laatste in 1980, en hebben de overgang naar de Riagg's meegemaakt of zijn kort na de totstandkoming van de Riagg's beroepsmatig actief geworden. De beschikbare informatie van de groep jongeren is weliswaar minder uitgebreid dan die van hun oudere collegae, maar geeft niettemin een goede indruk van de kijk van de jongere generatie op aspecten van de beroepsontwikkeling.

Al met al zijn er voor dit hoofdstuk gegevens beschikbaar vanaf omstreeks begin jaren vijftig tot halverwege de jaren tachtig van de twintigste eeuw. De informatie wordt geordend aan de hand van de volgende thema's: de taken van de verpleegkundigen, de samenwerking van verpleegkundigen met andere professionals, de verpleegkundigen en de opleiding, de verpleegkundigen en de veranderingen in de gezondheidszorg en, tot slot, de verpleegkundigen en hun motieven. Ofschoon deze thema's elkaar niet geheel wederzijds uitsluiten, zijn ze toch bruikbaar als uitgangspunt voor ordening.

\footnotetext{
${ }^{336}$ De vervolgscholing (kaderopleiding, Voortgezette Opleiding VO, cursussen gestalt- en systeemtherapie en de leertherapie) komt voor rekening van vier respondenten.

${ }^{337}$ Bakker, H., Goei, L. de, \& Vijselaar, J. (1994). Thuis opgenomen: uit de geschiedenis van de sociale psychiatrie in Nederland. Utrecht: NcGv.

${ }^{338}$ Padt, I. van der (1999). Hoopvol bezorgd: sociaalpsychiatrische verpleegkunde van de $20^{e}$ naar de $21^{e}$ eeuw. Eindhoven: Nederlandse Vereniging van Sociaal-Psychiatrisch Verpleegkundigen.

${ }^{339}$ Drie van de acht komen ook in "Hoopvol bezorgd ..." aan het woord.
} 


\subsection{De verpleegkundigen en de patiënten}

In de jaren na de Tweede Wereldoorlog pakken de nazorgdiensten, die zeker in de laatste oorlogsjaren nauwelijks hebben kunnen functioneren, de draad langzaam weer op.

Voor de verpleegkundigen betekent dit dat ze zich, net als voorheen, voornamelijk richten op patiënten die uit de inrichtingen zijn ontslagen. "Vooral in het begin waren het in hoofdzaak mensen die opgenomen waren geweest in een psychiatrische inrichting". ${ }^{340}$ Maar daar blijft het niet bij. "Daarnaast hadden we demente bejaarden... Voor hen was praktisch geen opname mogelijk, die begeleidde je thuis. Dan hadden we een groot aantal zwakzinnigen, diep zwakzinnigen die allemaal wachtten op een plaatsje in een inrichting. En verder ... het CAD was er nog niet, dus je had veel van die randgevallen. En altijd ook nog een groepje psychisch gestoorde delinquenten die in de maatschappij verbleven. In grote lijnen waren dat onze patienten". ${ }^{341}$ Het type patiënt kan per werkplek variëren. Daar waar bijvoorbeeld een Jeugd-Psychiatrische Dienst actief is, wordt er nauwelijks gewerkt ten behoeve van kinderen.

Vanaf halverwege de jaren vijftig, nadat de psychofarmaca beschikbaar zijn, wordt de controle op medicijngebruik een nieuw aandachtsgebied van de verpleegkundigen. Vanaf diezelfde tijd komen er, eerst in de steden, later ook daarbuiten, patiënten bij "... die nog niet opgenomen waren geweest. Ze kwamen bijvoorbeeld bij een psychiater in het ziekenhuis op spreekuur. Die vroeg dan begeleiding van ons. Geleidelijk aan kregen we meer verwijzingen via de huisartsen. Ze vroegen aan ons: wilt $u$ daar niet even gaan kijken, want daar zijn problemen thuis". ${ }^{342}$ Voorzorg, waarmee wordt bedoeld het voorkomen van opnames, wordt een nieuw thema. ${ }^{343}$ Behalve dat de ene groep niet, de andere wel opgenomen is geweest, zijn er in wezen geen verschillen tussen de voor- en de nazorgpatiënten. ${ }^{344}$

Aan de werkzaamheden van de verpleegkundigen verandert dan ook tot in de tweede helft van de jaren zestig weinig tot niets. Ze zijn zeer concreet en zeer variërend, zoals stimuleren van patiënten om naar het spreekuur te gaan; motiveren tot (her)opname in de inrichting; voorbereiden op ontslag; helpen bij het vinden van huisvesting zoals pension, kosthuis en pleeggezin; bemiddelen bij het vinden van gepast werk; helpen bij het vinden van nieuwe huisraad na een ruzie; regelingen treffen met sociale diensten en kredietbanken; mee boodschappen doen; patiënten

\footnotetext{
${ }^{340}$ Bakker, H., Goei, L de, \& Vijselaar, J. Thuis opgenomen: uit de geschiedenis van de sociale psychiatrie in Nederland, 42-43.

${ }^{341}$ Ibidem, 42-43.

${ }^{342}$ Ibidem, 38,

${ }^{343}$ In hoofdstuk 5 is aan de orde gekomen dat het in Limburg tot begin jaren zeventig duurt tot de voorzorg goed van de grond komt.

${ }^{344}$ Bakker, H., Goei, L. de, \& Vijselaar, J. Thuis opgenomen: uit de geschiedenis van de sociale psychiatrie in Nederland, 38.
} 
leren omgaan met geld; als het helpt om contact te leggen samen de was doen; zorgen dat de kinderen naar school blijven gaan, als het niet anders kan ze zelf brengen op de fiets; "er zijn, de tuin harken, schaapjes voeren, niet loslaten".(6) Het "er zijn" gaat een enkele keer zover dat patiënten in huis worden genomen als er elders geen onderdak is. In de jeugdpsychiatrie gaat het er vaak om dat ouders leren structuur aan te brengen in het leven van hun kinderen. Op tijd naar bed, op tijd opstaan, op geregelde tijden eten, tijd en ruimte creëren om huiswerk te maken. Schoolbezoeken en het geven van voorlichting en omgangsadviezen aan leerkrachten zijn ook regelmatig aan de orde en hebben blijkbaar resultaat. "Menige leerkracht presteerde meer dan een psychiater".(1) Contacten met kinderrechters en voogdijinstellingen horen erbij.

Crisisinterventie zit ook in het takenpakket. Een man op een boerderij is verward en staat op het punt gewelddadig te worden. De sociaalpsychiatrisch verpleegkundige blijft er de hele nacht want ze voelt "als ik hier wegga, dan gaat het helemaal fout, dan vallen er slachtoffers".(2) Ze weet de man zover te krijgen dat de psychiater langs mag komen. Uiteindelijk kan er dan een kortdurende opname worden geregeld. In de steden komt crisisinterventie vaker voor dan op het platteland, deels omdat die in de steden beter is georganiseerd, deels omdat het op het platteland door de afstanden vaak niet mogelijk is om bij crises tijdig te interveniëren: de afstanden zijn er te groot. Met de komst van 24-uursdiensten, eerst in de steden, wordt de crisisinterventie steeds meer een aparte tak van dienst.

In de tweede helft van de jaren zestig kondigen zich veranderingen aan. "In de loop der jaren ging men zien dat de ziekte in veel gevallen niet alleen veel moeilijkheden met zich meebracht bij het weer ingepast raken van de patiënt in zijn milieu, maar vooral dat in bepaalde gevallen de verstoorde relatie tussen mensen tot manifestatie van ziekteverschijnselen leidde". ${ }^{345}$ Het werk van de verpleegkundigen verandert langzaam van inhoud en beperkt zich niet langer tot de bekende controlerende en faciliterende activiteiten. Sommigen gaan zich specialiseren, bijvoorbeeld in groepswerk en, later, in vrouwenhulpverlening. "De overgang van groepswerk naar vrouwenhulpverlening was eigenlijk niet zo groot. Door het groepswerk waar ook veel chronische vrouwen zaten, lag dat voor de hand ... Ik had er altijd al een hekel aan dat deze vrouwen het etiket 'zeur' kregen. In die groepen hoorde je dan wat er achter de façade zat ....". ${ }^{346}$

De veranderingen voltrekken zich op de ene plaats later dan op de andere. "Eind jaren zeventig kwam de groep mensen die een meer therapeutische benadering vroeg. Deze groep was groeiende, en die periode heeft lang geduurd. Dat was

\footnotetext{
${ }^{345}$ Citaat afkomstig uit de eindscriptie voor de urgentieopleiding maatschappelijk werk aan de Katholieke Sociale Academie De Aemstelhoorn te Amsterdam, geschreven door de sociaalpsychiatrisch verpleegkundige mevr. R. Nouwens. In I. van der Padt, Hoopvol bezorgd: sociaalpsychiatrische verpleegkunde van de $20^{\text {ste }}$ naar de $21^{\text {ste }}$ eeuw, 136.

${ }^{346}$ Padt, I. van der. Hoopvol bezorgd: sociaalpsychiatrische verpleegkunde van de $20^{e}$ naar de $21^{e}$ eeuw, 39.
} 
heel dankbaar werk". ${ }^{347}$ Niet iedereen is met de "therapeutisering"onverdeeld gelukkig. "Ze willen allemaal therapeut worden. Ze willen op deze manier hun beroepsidentiteit verkrijgen". ${ }^{348}$ Ook later, begin jaren tachtig, is er verschil in opvatting over het al dan niet therapeutisch bezig zijn. Bij degenen die gezinstherapeutische behandeling toepassen "... heerste wel zoiets van wij zijn met het echte werk bezig ... Dat waren de mensen die ècht bezig waren en wij waren maar wat aan het klungelen". 349

\subsection{De samenwerking van de verpleegkundigen met andere professionals}

De werkzaamheden van de meestal fulltime werkende verpleegkundigen krijgen grotendeels vorm in het assisteren van de veelal parttime werkende psychiaters bij de spreekuren en bij het afleggen van huisbezoeken.

Assisteren bij de spreekuren houdt in het bijhouden van de administratie en het samen zien van patiënten.(12) De spreekuren worden lang tijd niet altijd onder gunstige omstandigheden gehouden. "We zaten te midden van opgezette reigers en roerdompen, die stonden heel knus om me heen. Ik ruik nog de conserveringsgeur van al die opgezette vogels. Een stank van jewelste". ${ }^{350}$ Soms is er zelfs geen ruimte beschikbaar. "Feitelijk werkte je vanuit je huis. 's Morgens van half negen tot half tien kon iedereen bellen. Daarna stapte ik in de auto. Op huisbezoek" ${ }^{351}$ Het zal tot ver in de jaren zestig duren eer de huisvesting van de diensten op niveau komt. Tegen die tijd houden bij sommige diensten de verpleegkundigen zelf open spreekuur waar patiënten zonder afspraak binnen kunnen lopen.(8)

Binnen de nazorgdiensten zijn de verpleegkundigen de spil en de constante factor. Ze kennen de patiënten en hun woon- en werkomgeving, zijn goed op de hoogte van de sociale kaart en beschikken over een uitgebreid netwerk van personen en instanties. Het komt erop neer dat het overgrote deel van het werk wordt gedaan door de verpleegkundigen. "In Noord-Holland zei men wel eens: de dokters kunnen wat ons betreft wel weg, maar de zusters, die hebben we nodig". ${ }^{352}$ De psychiaters leunen dan ook zwaar op de verpleegkundigen.

Ofschoon de psychiater formeel de baas is, hebben de verpleegkundigen veel ruimte om hun activiteiten naar eigen kunnen en inzicht uit te voeren. Bij de dienst van een GG\&GD krijgen ze, "afhankelijk van de baas, meer of minder ruimte. Op het

\footnotetext{
${ }^{347}$ Ibidem, 136.

${ }^{348}$ Klinische les: verschrikkelijke ziektes. Sociale Psychiatrie, 1985, 5(16), 13.

${ }^{349}$ Padt, I. van der. Hoopvol bezorgd: sociaalpsychiatrische verpleegkunde van de $20^{\text {ste }}$ naar de $21^{\text {ste }}$ eeuw, 94.

${ }^{350}$ Bakker, H., Goei, L de, \& Vijselaar, J. Thuis opgenomen: uit de geschiedenis van de sociale psychiatrie in Nederland, 83.

${ }^{351}$ Ibidem, 83.

352 Ibidem, 89.
} 
ochtendrapport werd het beleid uitgestippeld maar binnen dat beleid was je je eigen baas".(1) Bij een provinciale dienst krijgt de verpleegkundige "erg veel ruimte waarvoor je dan ook verantwoordelijk was".(2) Die ruimte is in dit geval zo groot dat zij zonder tussenkomst van de psychiater opnames kan regelen. Zij doet er altijd alles aan op opnames te voorkomen, dus als zij vindt dat een opname nodig is, dan wordt dat aangenomen. De verwijzing naar de inrichting wordt naderhand door de psychiater geformaliseerd.

Het gebeurt ook, met name in de provincie, dat verwijzers rechtstreeks contact opnemen met de relatief makkelijk bereikbare verpleegkundigen die dan later de psychiaters informeren. In een situatie, begin jaren zestig, waar geen psychiater beschikbaar is, draait de verpleegkundige zelfstandig de nazorgdienst. Voor de behandeling, dat wil zeggen het voorschrijven van medicijnen, neemt ze contact op met de huisarts van de patiënt. Het is ook een huisarts die haar vraagt om bij een van zijn patiënten langs te gaan om de situatie ter plekke te beoordelen. Voor de rest vult de verpleegkundige haar werk zelf in.(8)

Overleg tussen verpleegkundigen en psychiaters gebeurt in grote lijnen, tijdens de teambijeenkomsten bij de grotere diensten of tijdens ontmoetingen tussen psychiaters en verpleegkundigen van de provinciale en regionale diensten. Daar waar de diensten gebrekkig zijn gehuisvest, kan de plaats van overleg variëren van de woning van de psychiater, een hotelkamer naast de kamer waar hij zijn tijdelijk onderkomen heeft tot een ruimte in een school of in een ziekenhuis. Als het niet anders kan, bijvoorbeeld in geval van een acute situatie, verloopt het contact telefonisch.

Schriftelijk rapporteren door de verpleegkundigen is niet vanzelfsprekend. "Ik heb nooit veel geschreven. Aanvankelijk had ik er de tijd niet voor, te druk. Later hing er een sfeer van niet te veel opschrijven want je weet nooit wat anderen er mee doen". (9) Waar wel schriftelijk wordt gerapporteerd, zoals bij de GG\&GD in Amsterdam, gebeurt dat anekdotisch. ${ }^{353}$ De verpleegkundigen hebben het rapporteren niet geleerd, anders dan de maatschappelijk werkenden. "Zij konden uitstekend rapporteren en brieven schrijven, in tegenstelling tot de toen (jaren zestig) werkzame spv-en die daar maar heel matig in waren". 354

Op verschillende werkplekken stellen de verpleegkundigen de sociale anamnese op ten behoeve van de psychiater. Daarin komen zaken aan de orde als gezinssamenstelling, woonomstandigheden, opleiding, werk, salaris, lichamelijke en psychische gezondheidstoestand, het vóórkomen van erfelijke belasting en de levensloop. In de jeugdpsychiatrie wordt in de anamnese ook uitgebreid aandacht besteed aan het verloop van zwangerschap en geboorte, de ontwikkeling van het kind in het ge-

\footnotetext{
${ }^{353}$ Akkermans, C. (2006). Aanspoelen aan de Achtergracht: maatschappelijke ontwikkelingen, clientèlevorming en de psychiatrische patiënten van de Amsterdamse GG\&GD (1933-1988), 181.

${ }^{354}$ Padt, I. van der. Hoopvol bezorgd: sociaalpsychiatrische verpleegkunde van de $20^{e}$ naar de $21^{e}$ eeuw, 133.
} 
zin en op school. De inhoud van de anamnese wordt vooral ter informatie van de psychiater gebruikt. "Daar werd niet zoveel mee gedaan, omdat dat niet goed kon. Wat moet je? Je kan mensen niets verbieden. Als ze willen trouwen dan trouwen ze. Gesprekken over geboortebeperking verliepen moeilijk".(1)

In het al dan niet hebben van contacten met professionals en instanties buiten de nazorgdiensten, evenals in de aard van die contacten, bestaat door de jaren heen veel variatie. De ene sociaalpsychiatrische verpleegkundige heeft veel contact met wijkverpleegkundigen. "Die in de kleine dorpen kenden iedereen en alles en boden vaak goede ingangen".(9) Er worden ook contacten onderhouden met de gezinszorg, ook nu weer op het platteland. "Daar besprak je moeilijke situaties mee en adviseerde je hoe ze met patiënten konden omgaan. Die mensen waren helemaal niet opgeleid en zaten er vaak dicht bovenop".(7) Een verpleegkundige die werkzaam is in de jeugdpsychiatrie in de stad, heeft die contacten nooit. "Het waren toch wel gescheiden circuits, de GGZ en de AGZ(Algemene Gezondheidszorg)".(1)

De samenwerking met de psychiatrische inrichtingen verloopt moeizaam, met name rond het ontslag van patiënten. Volgens een verpleegkundige bij een GG\&GD was "het een gunst als je voor het ontslag van iemand iets te horen kreeg. Voorbereiding was er dan ook niet bij".(1) Ook in de provincie is "het besluit tot ontslag vaak al genomen zonder dat wij ervan wisten. Het was vaak vragen om erbij betrokken te worden, een volgende keer. Erg moeizaam allemaal".(6). Voor zover de nazorgverpleegkundigen contact hebben met collega's in de inrichtingen gaat het om afdelingshoofden. Die hebben weinig idee van de mogelijkheden buiten. "Ze hadden vaak dat wat ze de patiënten graag gunden tot uitgangspunt gemaakt. Dat is wel aardig, maar vaak niet realistisch. Als de patiënt zelf dat niet kan of wil, dan heb je een probleem".(7) Bij uitzondering zijn de contacten met de inrichtingen beter. "Ik kon vaak informatie geven over een thuissituatie, die zij niet hadden. Daarmee konden ze dan hun voordeel doen".(2) De ene dienst is dan de andere waard. Als de nazorgverpleegkundige goed wordt geïnformeerd, dan weet ze dat een inrichting nog ruimte heeft voor een opname, ook al wordt dat officieel ontkend, en kan die opname alsnog worden gerealiseerd. In de beginjaren van de nazorg zijn er rechtstreekse contacten tussen inrichtingspsychiaters en nazorgverpleegkundigen; formeel verlopen ze echter via de sociaalpsychiaters. ${ }^{355}$

Het ontwikkelen en onderhouden van een goed netwerk is voor de verpleegkundigen voorwaarde om het werk goed te kunnen doen. Dat betekent veel praten, veel overleg en het gezicht laten zien. "Ik kwam overal, ze kenden me overal en als er iets te doen was, werd ik altijd uitgenodigd".(9) Er zijn contacten met velerlei personen en instanties, even gevarieerd als de werkzaamheden die de verpleegkundigen ten behoeve van de patiënten verrichten. Het gaat onder meer om werkgevers, verhuurders van woningen, eigenaren van pensiontehuizen, ambtenaren van de sociale dienst, scholen, algemeen maatschappelijk werkenden, jeugdrechters, inter-

${ }^{355}$ Niet zelden zijn inrichtingspsychiater en sociaalpsychiater dezelfde persoon. 
naten en niet te vergeten de politie in crisissituaties. "Die waren al lang blij als je kwam, die waardeerden ons".(8)

Ook, misschien juist, als er, begin jaren tachtig, in buurtteams wordt gewerkt, blijft het belangrijk om een netwerk te hebben. " $k$ vond dat een SPV gewoon in de buurt moest werken en contact moest hebben met de huisarts, bouw- en woningtoezicht, de politie, de sociale dienst en ook met de afdeling groenvoorziening en de meteropnemer" ${ }^{356}$

\subsection{De opleiding van de verpleegkundigen}

De meeste verpleegkundigen uit de twee eerste lichtingen, dus zowel uit de groep die omstreeks 1950 als uit de groep die omstreeks 1960 begint, zijn dertig jaar of ouder als ze hun entree in de nazorg maken. Ze hebben veelal een lange opleidingsroute doorlopen, inhoudende de A, B, wijk- en kraamverpleging, eventueel de kinderaantekening plus de B-nazorg en ze hebben vaak al enige jaren werkervaring opgedaan. $^{357}$

De motieven om in de nazorg te gaan werken variëren. Voor sommigen is het werk in de somatische gezondheidszorg lichamelijk te zwaar. Ze komen via de psychiatrische verpleging terecht in de nazorg waar de lichamelijke belasting laag is. $(1,2)$ De sfeer in het ziekenhuis en de inrichting is ook een reden om er weg te gaan. "Het was er verstikkend. In de wijkopleiding kwam ik in aanraking met andere godsdiensten, levensovertuigingen ... Het was een openbaring. Je leerde je te verplaatsen in een ander, of ze nou wel of niet moeten of willen veranderen".(7) Het zich niet kunnen verenigen met de gang van zaken in de afdeling psychiatrie van het ziekenhuis waar ze hoofd is, is een argument voor een ander om over te stappen. "De diagnostiek rammelde. De psychiater had op zijn kamer een groot modelspooremplacement, dat in tweeën was gedeeld. Als hij echtpaartherapie deed, liet hij die mensen met de treintjes spelen".(6)

Er worden echter ook bewuste keuzes voor de nazorg gemaakt. Een verpleegkundige merkt dat ze als maatschappelijk werkende kennis van somatiek en psychopathologie mist. Ze doet de A, de B en haalt de wijk-, kraam- en kinderaantekening, alvorens ze de B-nazorg gaat doen.(8) Een ander kiest voor de jeugdpsychiatrie omdat ze affiniteit heeft met kinderen.(3) Min of meer toevallig in aanraking komen met de nazorg, en er dan willen blijven, of gewoon, erin rollen, komt ook voor.

Bij de verpleegkundigen die de opleiding EMGZ/GGZ volgen, variëren de motieven om actief te worden in de sociale psychiatrie al evenzeer als bij hun voorgan-

\footnotetext{
${ }^{356}$ Ibidem, 95.

${ }^{357}$ Een verpleegkundige die haar B-diploma heeft gehaald, wordt gevraagd of ze de B-nazorg wil doen. Meteen na het afronden daarvan gaat ze aan de slag. "Ik wilde ook mijn Witte Kruis ( de 'A') halen, omdat $i k$ vond dat dat erbij hoorde. Maar in Gouda was meteen iemand nodig, dus ik ben er in december 1943 naartoe gegaan". Ze is dan 25 jaar. Bakker, H., Goei, L. de, \& Vijselaar, J. Thuis opgenomen: uit de geschiedenis van de sociale psychiatrie in Nederland, 80.
} 
gers. Sommigen willen weg uit de inrichtingen omdat ze het daar niet zien zitten. "Als verpleegkundige was je alleen maar aan het poetsen en schoonmaken, tafels dekken en mensen wassen. Daadwerkelijk een bijdrage leveren aan het bevorderen van het welzijn van de mensen was er niet bij". ${ }^{358}$ Anderen kiezen om wat meer uitgesproken redenen voor een nieuwe start. "... ik was van mening dat het systeem invloed had op het disfunctioneren van de cliënt en ook bij de behandeling invloed op het functioneren kon uitoefenen. Om die reden wist ik al snel dat ik extramuraal wilde gaan werken". 359

Over de opleiding B-nazorg wordt met weinig enthousiasme gesproken. "Die laatste opleiding vond ik flut, het was maar een half jaartje en het stelde niet veel voor". ${ }^{360}$ De verpleegkundigen krijgen door de opleiding wel aandacht voor het belang van sociale en maatschappelijke factoren zoals armoede, woonomgeving, gezinssamenstelling en arbeidsomstandigheden. "Je had kennis van en ervaring met psychopathologie en die gebruikte je in combinatie met de kennis en het inzicht van sociaal-maatschappelijke zaken. Het was heel practisch allemaal".(1) Voor de praktijk van alledag biedt de opleiding weinig houvast en van een kennisdomein is geen sprake. "Er bestond niet zoiets als het vak sociale psychiatrie... Het zit voor een groot deel in je, en dan komt daar de ervaring bij".(8)

Als ze beginnen met werken in de nazorg, zijn de verpleegkundigen dan ook niet altijd even goed voorbereid op wat ze tegenkomen. "Veel dingen herkende ik helemaal niet. Dan was ik in een pension geweest en vertelde dat eerder een zwaar opgemaakte zwarte dienstbode opendeed, en nu een blonde. Het was natuurlijk een bordeel, maar dat zag ik niet" ${ }^{361}$ Het ontbreekt niet enkel aan een goede opleiding, maar ook aan inwerken en begeleiding op de nieuwe werkplek. "Je was dus eigenlijk niet opgeleid, maar moest meteen beginnen. Op mijn eerste werkdag lag er een stapel dossiers op mijn bureau. Daarmee ging ik aan de slag".(3)

Rond 1970 ontstaat bij de sociaalpsychiatrisch verpleegkundigen belangstelling voor bijscholing. "Er kwam een psycholoog bij. Die sprak een andere taal dan de psychiater, en wij konden daarin niet zo goed mee. (7) Er schort iets aan hun opleiding en vaardigheden, zo realiseren ze zich. "Om te beginnen was ik goed opgeleid, vond ik. Later bleken we toch wel erg verzorgend opgeleid". (7) De scholing blijkt ruimte te bieden voor een bredere kijk op de zaken. "Er werd meer ingegaan op de normaal functionerende mens, op psychologische aspecten en mechanismen, niet meer enkel redeneren vanuit de psychopathologie... In de verpleegkundige opleidingen kreeg je niet de beschikking over woorden, je leerde niet verbaliseren wat je $z^{\prime \prime}$.(6)

\footnotetext{
${ }^{358}$ Padt, I. van der. Hoopvol bezorgd: sociaalpsychiatrische verpleegkunde van de $20^{\text {ste }}$ naar de $21^{\text {ste }}$ eeuw, 17.

${ }^{359}$ Ibidem, 13.

${ }^{360}$ Ibidem, 60 .

${ }^{361}$ Bakker, H., Goei, L. de, \& Vijselaar, J. Thuis opgenomen: uit de geschiedenis van de sociale psychiatrie in Nederland, 76.
} 
De behoefte aan scholing en aan andere werkwijzen wordt ook gevoed door contacten met maatschappelijk werkenden. In de loop van de jaren nemen die toe, met name met de maatschappelijk werkenden van de Medisch Opvoedkundige Bureaus en van de Bureaus voor Levens- en Gezinsmoeilijkheden. De verpleegkundigen merken dat die goed zijn opgeleid en over andere vaardigheden beschikken dan zijzelf. "Ik herinner me een mevrouw bij wie ernstige incestproblematiek naar boven kwam. Ik wist niet hoe daarmee verder, en toen heeft een maatschappelijk werker van het bureau voor Levens- en Gezinsmoeilijkheden me goed geholpen".(7) De verpleegkundigen zien ook dat de maatschappelijk werkenden methodischer aan de slag gaan dan zijzelf. "Die bespraken alles, planden het aantal activiteiten, maakten uitgebreid verslagen en hadden een kleine case load... Ik dacht altijd: dan ga ik daar en daar naar toe, en dan ga ik meteen even bij die en die langs, en dan snel een kop soep met een broodje en dan verder".(2) Een enkele keer is er sprake van verschil in opvattingen tussen sociaalpsychiatrisch verpleegkundigen en maatschappelijk werkenden. Dat wordt door de eersten geweten aan de te theoretische oriëntatie van de laatsten.(8) ${ }^{362}$ Maar er zijn ook verpleegkundigen die dat anders zien. Sommigen gaan de opleiding tot maatschappelijk werkende doen. "Mijn motivatie hiervoor was dat ik altijd meer wilde weten als daartoe gelegenheid was... Naar mijn mening boden de maatschappelijk werk opleidingen materiaal dat zeer bruikbaar was voor de uitdieping en de professionalisering van het verpleegkundig beroep". ${ }^{363}$

Niet iedereen voelt overigens voor bijscholing en het is een zaak van persoonlijke afwegingen om er al dan niet aan te beginnen."Nee, ik ben niet psychotherapeutisch geschoold. Ik was bang toen, denk ik, dat ik dat niet aankon. Ik heb wel dingen opgepikt van anderen, maar ik geloof dat ik dat niet aankon".(8) Het kan ook anders worden uitgedrukt. "Ik heb dat niet gewild; niets voor mij. Als anderen dat willen, vind ik het goed. Je maakt je eigen keuzes".(1) Daar komt nog bij dat sommige vaardigheden blijkbaar niet aangeleerd kunnen worden. "Zaken goed en begrijpelijk uitleggen, kort bij de mensen blijven staan, steun bieden, luisteren, bevestigen... Psychiaters en psychologen kunnen dat vaak niet. Misschien is het wel het type mens

\footnotetext{
${ }^{362}$ In 1972 verschijnt de nota "Taak en plaats van de maatschappelijk werkende bij de SPD". In de nota wordt gepleit voor het inschakelen van maatschappelijk werkenden ter getalsmatige maar ook inhoudelijke aanvulling op de verpleegkundigen die "de neiging hadden patiënten te infantiliseren vanwege de sterk verzorgende gerichtheid van het werk. De SPV beschikt gemiddeld over een geringe kennis van het methodisch werken met het mogelijke nadeel van de vlucht in het ziektemodel, de verzorging en infantiliseren van de patiënt met nogal eens een te negatief beeld over zogenaamde groeimogelijkheden". De nota wordt een discussiestuk, onder meer binnen het sociaalpsychiatrisch studiegezelschap waaraan psychiaters deelnemen. Een verpleegkundige, die zelf de opleiding maatschappelijk werk heeft gedaan, is betrokken bij het tot stand komen van de nota zonder dat haar duidelijk is dat er "over dit punt een strijd gaande was en dat het in hogere regionen ook een 'politiek' item was... . Ik heb nooit directe confrontaties met hen (maatschappelijk werkenden) meegemaakt... . Elders was daar al veel meer gesprek over dan ik besefte". Padt, I. van der. Hoopvol bezorgd: sociaalpsychiatrische verpleegkunde van de $20^{e}$ naar de $21^{e}$ eeuw, 138.

${ }^{363}$ Ibidem,120-121.
} 
dat kiest voor dit werk, waardoor je er geschikt voor bent... Maar je moet ook goed opgeleid zijn, anders verdrink je".(1)

Er wordt op sommige werkplekken ook aan "training on the job" gedaan, bijvoorbeeld in de vorm van werkbegeleiding door de psychiater. "Was hij klinisch georiënteerd, dan viel dat wat tegen. Als hij wat moderner was, dan werd gedrag van patiënten meer geduid en verklaard, of dan werd jouw eigen rol in het geheel betrokken. Dat was vaak verhelderend".(7)

Kennis van en ervaring met psychopathologie blijven belangrijk. De verpleegkundigen hebben gauw in de gaten als er iets mis is of dreigt te gaan, bijvoorbeeld als iemand psychotisch begint te worden. Het hebben van ervaring in de somatiek biedt vaak een makkelijke ingang. "Je kon bij wijze van spreken het bedplassen als aanknopingspunt nemen".(3) Dat geldt ook nog in de jaren zeventig. "Ik weet nog goed dat een huisarts uit mijn rayon me belde om te vragen om bij een bepaalde man te gaan kijken omdat hij zo in de war was. Ik heb toen een huisbezoek afgelegd en ik zag dat hij inderdaad in de war was maar het ook benauwd had. Ik heb toen zijn pols gevoeld... Het bleek dat deze man een ernstig gedecompenseerd hart had waardoor hij in de war raakte". ${ }^{364}$

Vanaf 1974 komen de eerste verpleegkundigen-nieuwe-stijl beschikbaar na het volgen van de opleiding EMGZ/GGZ. Zoals uit hoofdstuk 5 duidelijk is geworden, is die opleiding een breuk met de opleiding B-nazorg. In de geest van "de jaren zeventig" staat in de nieuwe opleiding zelfontwikkeling voorop. "Ik heb de opleiding ('72'74) gevolgd in Groningen en ik had alle tijd om mezelf te ontwikkelen. Dat kreeg toen veel aandacht, daar werd veel tijd aan besteed door middel van trainingen en supervisie" ${ }^{365}$ Het verwerven van kennis en theoretisch inzicht is blijkbaar minder belangrijk en niet iedereen is onverdeeld tevreden over de opleiding. "Ik maakte kennis met vakken als sociologie en filosofie, dat interesseerde me... Anderzijds vond $i k$ het gênant hoe weinig structuur er in die opleiding zat en hoe weinig concrete eisen er werden gesteld. Niet aan persoonlijke geschiktheid maar ook niet aan theoretische kennis". ${ }^{366}$ Het komt voor dat docenten vragen wat studenten nodig hebben voor hun vak. "Waar het op neer kwam was dat hij gewoon niet wist wat hij ons moest bijbrengen... Er waren grote verschillen tussen docenten, van sommigen kon je echt veel leren en anderen gingen uit hun dak omdat ze speed gebruikten. Zo was die tijd, heel turbulent". ${ }^{367}$

De opleiding sluit niet aan op de praktijk. "Het verschil was te groot. Het doen van onderzoek, systematisch leren werken, daar gaat het om in de praktijk, maar dat heb ik zelf moeten leren, dat heb ik niet meegekregen van de opleiding..." ${ }^{368}$

\footnotetext{
${ }^{364}$ Ibidem, 49.

${ }^{365}$ Ibidem, 115.

${ }^{366}$ Ibidem, 93

${ }^{367}$ Ibidem, 141.

${ }^{368}$ Ibidem, 54.
} 
Anders dan in die jaren vaak wordt benadrukt, komt het belang van de sociale omgeving in de opleiding niet altijd tot uitdrukking. "Ik heb niet de ervaring dat die opleidingen werkten vanuit het sociaalpsychiatrisch gedachtegoed en je dat meegaven als student". ${ }^{369}$ Met sociaalpsychiatrisch gedachtegoed wordt bedoeld: de patient niet enkel als individu zien en werken vanuit en met de sociale context, bijvoorbeeld door het betrekken van de familie in de behandeling.

De stage, die onderdeel is van de opleiding, wordt positiever beoordeeld dan het theoretische gedeelte. "In die zin was de stage een belangrijk onderdeel van de opleiding, zo niet het belangrijkste deel... Je kunt nog zoveel oefenen, maar op het moment dat je eigen eerste klant voor je zit, wordt het echt". ${ }^{370}$

Ook na het afronden van de opleiding is de praktijk van veel invloed op het individuele proces van professionaliseren. "In de praktijk heb ik geleerd hoe ik met cliënten aan de slag moest". ${ }^{371}$ Aan werkbegeleiding en het opdoen van ervaring wordt veel waarde gehecht. "In onze Riagg had een nieuwe collega recht op een jaar mentorschap, pas na twee jaar ervaring mocht hij of zij deelnemen aan de crisisdienst. Tenzij iemand aangaf dat al eerder te kunnen en de club SPV-en dat ook verantwoord vond". ${ }^{372}$ Niet enkel coaching door verpleegkundigen is aan de orde. "Ik heb veel gehad aan de samenwerking met andere disciplines zoals de psychotherapeuten, we consulteerden elkaar wederzijds, dat was heel gebruikelijk in ons team". ${ }^{373}$ Ervaren werkers, van welke professionele achtergrond dan ook, hebben een belangrijke voorbeeldfunctie voor de beginnende verpleegkundigen. ${ }^{374}$ Maar het is niet overal even goed geregeld. "Vanuit de praktijk op de Riagg werd je weinig aangeboden. Je moest alles zelf maar uitzoeken, dat vond ik lastig. Intervisie bijvoorbeeld was er niet ..." 375

\subsection{De verpleegkundigen en de veranderingen in de gezondheidszorg}

In de sociaalpsychiatrische diensten, die in de loop van de jaren zestig beginnen te veranderen, worden aan de verpleegkundigen langzaamaan nieuwe eisen gesteld. De veranderingen gaan langzaam en ook nu weer voltrekken ze zich niet overal in hetzelfde tempo, in de provincie langzamer dan in de grote steden. "Toen de eerste binnen onze dienst kwam, was dat één psycholoog voor de hele provincie. Dus je kunt je wel voorstellen dat er niet meteen therapie aan te pas kwam. Het was meer onderzoek en advies aan ons. Pas later kreeg je echtpaartherapieën, gezinstherapie-

\footnotetext{
${ }^{369}$ Ibidem, 105-106,

${ }^{370}$ Ibidem, 54.

${ }^{371}$ Ibidem, 108.

${ }^{372}$ Ibidem, 81.

${ }^{373}$ Ibidem, 91.

${ }^{374}$ Ibidem, 161

${ }^{375}$ Ibidem, 163.
} 
$e n^{\prime \prime} .{ }^{376}$ De aandacht voor gezinnen is weliswaar niet nieuw, "maar dat je ook wat kunt veranderen door te praten, dat was nieuw" ${ }^{377}$

Het onderscheid tussen begeleiden en therapie is niet erg duidelijk. "Als ik met iemand een gewoon gesprek heb, ben ik soms bezig te behandelen. Ja, de patiënt werd natuurlijk wel eens teruggevraagd, maar of je dat nou therapie moet noemen?" 378

Een groot deel van de activiteiten van de verpleegkundigen blijft bestaan uit het afleggen van huisbezoeken. "Die werden vooral besteed aan praten, veel praten, adviezen geven aan de patiënt en betrokkenen, steunen, begrip tonen, structuur bieden. Gewoon praktisch doen, plat Amsterdams praten".(1) De taal van de ander spreken is belangrijk. "Als het nodig was, dan kon ik heel fijntjes doen bij de chiq van de goede buurt".(6)

In de jaren zeventig beginnen de verpleegkundigen ook met spreekuur op afspraak. Dat levert, vergeleken met het doen van huisbezoeken, tijdwinst op. Voordeel is ook dat de omgeving van de patiënt niet weet dat er contacten zijn met iemand uit de wereld van de psychiatrische hulpverlening. "Misschien kwam het ook wel door de therapeutische oriëntatie die in de mode kwam, waaraan je zelf ook niet helemaal ontkwam, waardoor het aantal huisbezoeken terugliep". (7) Maar er zijn ook inhoudelijke afwegingen om niet op huisbezoek te gaan. "Ik ging ervan uit dat als ik mensen door huisbezoeken of langerdurende schriftelijke communicatie op het bureau had binnengehengeld er vijf stappen vooruit waren gezet in het hulpverleningsproces". ${ }^{379}$

De antipsychiatrie die in de tweede helft van de jaren zeventig op haar hoogtepunt is, heeft weinig diepe sporen achtergelaten. Veel enthousiasme wordt er evenwel ook weer niet voor opgebracht. "Met de antipsychiatrie kwam alles in een stroomversnelling. Het rare was dat je toen zowat niemand meer mocht laten opnemen. Het was eigen verantwoordelijkheid voor iedereen, ook als ze die niet konden dragen".(8)

Een verpleegkundige die in de ogen van een psycholoog niet de juiste houding heeft aangenomen ten opzichte van een psychotische vrouw meent "dat het geen enkele zin had haar op die andere manier te benaderen. Dat was de invloed van de antipsychiatrie dat je iedereen altijd de waarheid moest zeggen. Dat was niet altijd goed en voor sommige mensen zelfs slecht. De ideologie werd een dogma, daar heb ik niet aan meegedaan hoor". Ze vervolgt dan laconiek: "Ik zou die periode als volgt willen karakteriseren: als er een veiligheidsspeld verkeerd had gezeten en je werd geprikt, dan was je, bij wijze van spreken, gefrustreerd voor de rest van je leven" 380

\footnotetext{
${ }^{376}$ Ibidem, 116

${ }^{377}$ Ibidem, 116.

${ }^{378}$ Ibidem, 115

${ }^{379}$ Padt, I. van der. Hoopvol bezorgd: sociaalpsychiatrische verpleegkunde van de $20^{\text {ste }}$ naar de $21^{\text {ste }}$ eeuw, 4.

${ }^{380}$ Ibidem, 61.
} 
Volgens een ander speelt de antipsychiatrie geen grote rol in haar werk. Trimbos heeft dan wel belangrijke ideeën ontwikkeld, maar dat gegeven heeft weinig consequenties gehad voor haar werk, in dit geval in de jeugdpsychiatrie.(1) Misschien is het zo, dat de verpleegkundigen zich er niet zo mee bezighouden, omdat ze vinden dat hun "doelgroep" er niet veel aan heeft. "lk heb me in de periode er sterk voor gemaakt dat de chronische patiënten niet verstoken bleven van de hulp waarvan ik vond dat ze die echt nodig hadden". ${ }^{381}$ Wat de patiënten echt nodig hebben is wat vanaf begin jaren negentig ook wel bemoeizorg wordt genoemd.

Maar de veranderingen hebben ook goede kanten. "Ik kreeg minder cliënten en durfde meer de diepte in, om meer bij het verdriet van de mensen uit te komen. Het is meer therapie, zeker. Vroeger was het alleen maar sociale psychiatrie, begeleiden, praktische dingen doen. En dat is nog steeds van belang, maar je doet sommige mensen tekort als je daar bij blijft. Als je niet de diepte ingaat" ${ }^{382}$

De komst van de Riagg's in 1982 is van een heel andere orde. "Later, toen het Riagg kwam, toen werd het allemaal anders. De leidinggevenden, dat waren zulke macho's. Ze waren ontzettend op zichzelf gericht... Er werd heel veel vergaderd, geouwehoerd... Productieafspraken! Je werkt toch niet in een fabriek. Al die energie die er werd verknoeid, als we die eens in het werk hadden kunnen stoppen".(1)

Bureaucratisch is een woord dat meer dan één keer wordt gebruikt. "Later werd het allemaal bureaucratisch, zeker met de komst van het Riagg. ledereen ging toen zo presteren, de sfeer werd een stuk haniger". (8)

De tot dan toe redelijk solistisch werkende sociaalpsychiatrisch verpleegkundigen voelen zich op hun vingers gekeken. "Tot de Riagg-vorming was het erg goed. Daarna is het wel zó bureaucratisch geworden. Die jonge psychiaters, alles wilden ze onder controle houden. Alsof ik niet wist wanneer een situatie ernstig was en een arts moest worden ingeschakeld... . Er moest wel gesaneerd worden, want het was een speeltuin geworden... maar de manier waarop... Om de wachtlijsten te bekorten kregen patiënten vijf gesprekken en moesten ze opdrachten uitvoeren. Van speeltuin naar vijfgesprekkenmodel ... Ik ben er nu mee rond, maar toen vond ik dat ze mijn baan hadden afgenomen".(7)

Hoewel de noodzaak tot veranderen wel wordt gezien, wordt daaraan niet altijd van harte meegewerkt. "De fusies en reorganisaties hebben veel energie en ellende gekost. Het kwam allemaal van bovenaf, zonder overleg... Natuurlijk, er moest worden gerationaliseerd. De tijd vraagt om veranderingen, maar het lijkt wel of het nooit meer rustig is geworden... Je gaat voor jezelf zorgen in al die turbulentie, anders red je het niet... Ik heb er ook wel goed onderuit zien gaan omdat het ze te veel werd". (6) Het gaat er dan ook niet altijd even fijnzinnig aan toe. Zo noemt een ma-

\footnotetext{
${ }^{381}$ Ibidem, 101.

${ }^{382}$ Bakker, H., Goei, L de, \& Vijselaar, J. Thuis opgenomen: uit de geschiedenis van de sociale psychiatrie in Nederland, 128.
} 
nager de sociaalpsychiatrisch verpleegkundigen " omgevallen boekenkasten... die weer terug in de praktijk moeten".(7)

In de nieuwe omstandigheden kunnen de verpleegkundigen hun eigen gang niet meer gaan. "Ik was heel moeilijk in de Riagg-structuur te passen. Ik heb een totaal andere manier van werken gekend. Dat zelfstandig werken van vroeger, je eigen gang kunnen gaan, je eigen creativiteit gebruiken, niet gebonden zijn aan allerlei regeltjes en wetjes, dat is verdwenen. Dat is een groot verschil met vroeger" ${ }^{383}$

Er wordt veel, soms te veel verantwoordelijkheid gelegd bij de patiënt. "Als hij geen medicijnen wilde hebben, dan hoefde dat ook niet. Als hij niet wilde komen, dan kwam hij maar niet. Maar de patiënt kan vaak niet overzien wat goed voor hem is en wat niet". ${ }^{384}$

Het is ook onpersoonlijker geworden, zowel voor klant als hulpverlener. Nabijheid en betrokkenheid raken uit de mode. "Ik vond dat echter een goede benaderingswijze omdat het een menselijke benadering is, vanuit deskundigheid maar ook vanuit een menselijke bewogenheid. Ik vond het grote nadeel van al die organisatorische veranderingen... dat betrokkenheid tot de cliënt veroordeeld werd... Ook dat kreeg je te horen van psychiaters die net twee jaar klaar waren, dat vond ik erg moeilijk". ${ }^{385}$ De patiënt moet voortaan gemotiveerd zijn voor de behandeling, terwijl dat lang niet altijd mogelijk is. "Een schizofreen die in z'n huis nergens toe komt, is niet gemotiveerd. Die komt niet naar de Riagg, al komt ie om... Daar moet je naartoe, die moet je opzoeken". ${ }^{386}$

Toch veroorzaakt de komst van de Riagg's niet enkel weerstand."Wij hadden vroeger geen psychologen in dienst, alleen af en toe een arts die voor het spreekuur kwam. Je hebt nu veel meer mogelijkheden. Al die soorten therapieën, die waren er niet. Wij hadden er geen kaas van gegeten" ${ }^{387}$ Ook de bundeling van verschillende diensten wordt positief gewaardeerd. "De Riagg staat in een bepaalde wijk en heeft één telefoonnummer. Dat is heel belangrijk, zo is de dienst direct bereikbaar". ${ }^{388}$

Voor de jonge garde is de overgang naar de Riagg's een interessante gebeurtenis. "Het was erg boeiend om in zo'n tijd in een instelling te werken. Er gebeurde ontzettend veel op het gebied van samenwerking en er werd veel aandacht besteed aan de wijze waarop het werk inhoudelijk vorm moest krijgen". ${ }^{389}$ Dat is overigens geen garantie voor instemming met de manier waarop dat laatste gebeurt. "De hulp vond vooral op kantoor plaats, en dat was niet mijn idee van hulpverlenen. Als men-

\footnotetext{
${ }^{383}$ Padt, I. van der. Hoopvol bezorgd: sociaalpsychiatrische verpleegkunde van de $20^{e}$ naar de $21^{e}$ eeuw, $23 / 24$.

384 Ibidem, 27.

${ }^{385}$ Ibidem, 78.

${ }^{386}$ Bakker, H., Goei, L. de, \& Vijselaar, J. Thuis opgenomen: uit de geschiedenis van de sociale psychiatrie in Nederland, 28.

387 Ibidem, 126.

${ }^{388}$ Ibidem, 125.

${ }^{389}$ Padt, I. van der. Hoopvol bezorgd: sociaalpsychiatrische verpleegkunde van de $20^{e}$ naar de $21^{e}$ eeuw, 141.
} 
sen zich moeten handhaven in de maatschappij, en dat was eigenlijk de voornaamste doelstelling, dan moet je er mijns inziens uit" ${ }^{390}$

$\mathrm{Er}$ is onderscheid merkbaar tussen oudere en jongere verpleegkundigen. "Je had SPV-en die de assistenten van de dokter waren, dat waren mensen die tegen hun pensioengerechtigde leeftijd aanzaten. Daarnaast waren er SPV-en waarvan ik erg onder de indruk was vanwege hun professionaliteit" ${ }^{391}$ Daarmee is echter niet gezegd dat alle jongeren meteen therapeut willen zijn. " $k$ hield niet van peuteren en had dan ook weinig affiniteit met collegae SPV-en die therapeut wilden worden. Ik vond dat je daar niet voor opgeleid was". ${ }^{392}$

Voor de groep minder redzame patiënten wordt individuele psychotherapie, gericht op inzicht en veranderen, niet geschikt geacht. De systeemtherapie biedt voor deze groep betere mogelijkheden. "Die is helemaal niet zo druk bezig met de pijn van het individu maar veel meer met het gezonde te verbreden en niet te pathologiseren en dat is het uitgangspunt van het sociaalpsychiatrisch gedachtegoed". ${ }^{393}$

Naast persoonlijke en meer inhoudelijke opvattingen over de taakinvulling blijft de werkomgeving van invloed op de activiteiten van de verpleegkundigen. "De pretenties waren niet hooggesteld bij de GGD... We pakten het pragmatisch aan, huizen ontruimen en mensen begeleiden die ernstig vervuild waren". ${ }^{394}$ Dat is anders bij een Riagg in Limburg "... waar heel breed gewerkt werd. Dat betekende dat je intakes deed, begeleidingen en behandelingen van ernstig psychiatrische patiënten maar ook echtpaarrelatie-therapie". ${ }^{395}$

De weerstand van veel oudere verpleegkundigen tegen de komst en de werkwijze van de Riagg's is, grofweg gesproken, tweeërlei. Belangrijk is dat veel verpleegkundigen zich in een sterk gerationaliseerde en bureaucratische structuur in hun professionaliteit miskend voelen. $\mathrm{Er}$ is een eind gemaakt aan de mogelijkheid om naar eigen inzicht en overwegend solistisch te werken. Ze voelen zich niet gehoord en niet betrokken bij de veranderingen die de komst van de Riagg's met zich meebrengen. Belangrijk ook is de opvatting dat een groep patiënten, de niet mondigen, de sociaal weinig redzamen, in de kou blijven staan. Die opvatting wordt kernachtig weergegeven met de vraag "Waar blijft de zorg voor de doodgewone mens?". 396

\footnotetext{
${ }^{390}$ Ibidem, 108.

${ }^{391}$ Ibidem, 141.

392 Ibidem, 161

${ }^{393}$ Ibidem, 84.

${ }^{394}$ Ibidem, 94.

${ }^{395}$ Ibidem, 108

${ }^{396}$ Bakker, H., Goei, L. de, \& Vijselaar, J. Thuis opgenomen: uit de geschiedenis van de sociale psychiatrie in Nederland, 131.
} 


\subsection{De drijfveren van de verpleegkundigen}

Met welke bedoelingen hebben de verpleegkundigen gewerkt, wat hebben ze bereikt, wat hebben hun activiteiten opgeleverd? Het beeld is dat van pragmatische doeners, van werkers die roeien met de riemen die ze hebben. Een paar voorbeelden van de oudere groep ter verheldering.

"Ik had een jongen in begeleiding uit een echte zwartekousenfamilie. De ouders waren zo stijf dat ze zowat van de bank vielen. Geen tv., een bijbel van 200 jaar oud... Het was duidelijk dat die jongen het niet zou trekken als hij door de ouders zou worden uitgestoten. Dan moet je binnen de gegeven kaders een leefbare situatie zien te bereiken".(7)

Tijdens een poliogolf moeten de kinderen worden gevaccineerd. De vader, een psychotische man die achterdochtig is, weigert dat. De verpleegkundige komt met hem aan de praat en geeft de risico's en het belang van de injectie aan. De man geeft toestemming onder voorwaarde dat de verpleegkundige erbij is als de spuit wordt gezet. Zo gebeurt het.

Als er uithuisplaatsing voor een jongen wordt aangevraagd, gaat een sociaalpsychiatrisch verpleegkundige het gezin bezoeken waar oma, die inwoont, de jongen als een gewoon kind beschrijft. De verpleegkundige ziet "in de woonkamer een prachtige vaas met zonnebloemen op de grond. Ik vroeg me af hoe dat nu toch kon bij zo'n ontzettend druk kind dat eigenlijk thuis niet te handhaven was ...". Moeder, die later met haar zoontje thuiskomt, "was erg druk en trok maar aan het kind zijn jas en zijn broek. Hij werd helemaal nerveus van zijn drukke moeder. Ik ben met het verhaal teruggegaan naar de staf en heb gezegd dat ik het niet eens kon zijn met een uithuisplaatsing". ${ }^{397}$

Als ze het doel van het werk omschrijven dan gebruiken de verpleegkundigen woorden als solidariteit, schade voorkomen, mensen niet laten vallen, troost geven, zorgen dat ze meetellen, het bestaan menswaardig maken en de situatie leefbaar houden. "Sommige mensen hebben lang, misschien hun leven lang hulp en aandacht nodig. Dat hoeft niet elke dag, maar je moet het lijntje open houden".(7) Beter maken of genezen zijn geen doelstellingen. "Spv-en hebben niemand beter gemaakt... Je probeerde de voorwaarden zo goed mogelijk te laten zijn en je perkte gedrag in, zodat mensen geen of zo weinig mogelijk problemen hadden... Maar dat ging wel met zorg, en dan moet er iemand zijn als dat nodig is ...".(8)

Of ze de patiënt aanpassen aan de samenleving of omgekeerd? "We pasten mensen op een bepaalde manier voor een stuk aan aan de samenleving... niet voor de samenleving, maar voor de mensen zelf... We probeerden de onaangepaste te helpen zodat hij zichzelf niet altijd tegenkwam".(1) Er zit niet veel anders op, want

${ }^{397}$ Padt, I. van der. Hoopvol bezorgd: sociaalpsychiatrische verpleegkunde van de $20^{e}$ naar de $21^{e}$ eeuw, 65-66. 
de samenleving laat zich moeilijk veranderen. "Daarover is veel geschreven, gepraat en gekletst, maar dat is eigenlijk niet gelukt".(6)

Dat de sociaalpsychiatrisch verpleegkundigen wel eens ver zijn gegaan, wordt niet uitgesloten. "Het was op een bepaalde manier sociale controle die we uitoefenden, maar dat was dus ook een vangnet. Dat zal zeker wel eens zijn doorgeschoten. Maar sociale controle is belangrijk ... dat hebben mensen ook nu nog nodig".(2) Soms moet er gewoonweg iets gebeuren, wordt de keuze om niets te doen niet verantwoord geacht. "Het hoefde niet op mijn manier, maar het moest wel op 'n manier".(1) Door de jaren heen, ook in het begin van de jaren tachtig, blijft de werkwijze op zijn tijd indringend. "Met betrekking tot de privacy van mensen was dat, in het licht van hoe we nu met privacy omgaan, natuurlijk volstrekt onverantwoord. We bespraken alles wat we tegenkwamen in de buurt ... Ik was er heilig van overtuigd dat dit goed was, het werkte ook ...". ${ }^{398}$

\subsection{Conclusies en discussie}

De generatie verpleegkundigen die kort na de Tweede Wereldoorlog actief wordt in de extramurale psychiatrie vormt een kleine twee decennia lang een stabiele beroepsgroep. Onder leiding van de psychiaters, maar met een grote mate van autonomie, verrichten de verpleegkundigen een breed scala aan activiteiten op het overzichtelijke en eveneens stabiele domein van de sociale psychiatrie.

In de kern zijn de werkzaamheden van de verpleegkundigen gericht op het faciliteren van ontslag van patiënten uit de inrichting en op het voorkomen van heropnames. Het informeren van de psychiaters, het uitoefenen van controle, het bieden van structuur en, in mindere mate, het beïnvloeden van omgevingsfactoren zijn daartoe belangrijke instrumenten. Ook als in de loop van de jaren vijftig langzaam het aandachtsveld wordt uitgebreid met het voorkomen van eerste opnames, voorzorg genoemd, verandert er aan werkzaamheden en instrumentarium weinig. Datzelfde geldt ook voor het soort problematiek waarop de verpleegkundigen zich richten. De activiteiten van de breed opgeleide verpleegkundigen zijn, net zoals het domein van de sociale psychiatrie, niet tot nauwelijks theoretisch onderbouwd en hebben een hoog praktisch, zo men wil common sense-gehalte.

Tussen verpleegkundigen en psychiaters heerst een hoge mate van overeenstemming omtrent het werkterrein waarop ze actief zijn en omtrent elkaars taken op dat werkterrein. Het gaat om de extramurale begeleiding van veelal chronische psychiatrische patiënten met een scala aan diagnoses en om wat in die tijd wel onmaatschappelijken worden genoemd. Doel is het verblijf buiten de inrichting mogelijk te maken. De in deeltijd werkende psychiaters geven leiding en houden consultatiebureau, de voltijd werkende verpleegkundigen gaan erop uit voor huisbezoe-

${ }^{398}$ Ibidem, 95. 
ken en assisteren bij de consultatiebureaus. Afhankelijk van de werkplek kunnen er nuanceringen worden aangebracht, bijvoorbeeld in enkele grote steden en in de jeugdpsychiatrie, maar het beeld is hiermee geschetst. Uit het gegeven dat beide beroepsgroepen gedurende jaren zonder noemenswaardige veranderingen met elkaar samenwerken kan worden geconcludeerd dat er onderlinge werkcoördinatie bestaat, dat ze elkaars werk positief evalueren en dat de interprofessionele ideologische en domeinconsensus hoog is.

Hetzelfde kan worden gezegd van de nazorgverpleegkundigen. Op nagenoeg vergelijkbare wijze geven ze invulling aan hun werkzaamheden voor een in grote lijnen gelijk blijvende groep patiënten. Ook indien er wordt gewerkt ten behoeve van een bijzondere groep, zoals in de jeugdpsychiatrie, bestaat er een grote mate van overeenkomst in de wijze waarop de werkzaamheden worden ingevuld en in de achtergrond van waaruit dat gebeurt. Begeleiden, controleren en structureren zijn de kernbegrippen. De intraprofessionele ideologische en domeinconsensus is hoog. Het feit dat de verpleegkundigen gedurende jaren op vrijwel dezelfde manier hun activiteiten vormgeven kan worden gezien als een aanwijzing voor werkcoördinatie en voor positieve evaluatie van elkaars werk. De nazorgverpleegkundigen, die vanaf begin jaren zestig sociaalpsychiatrisch verpleegkundigen worden genoemd, vormen een coherente beroepsgroep.

De veranderingen die zich in de sociale psychiatrie beginnen af te tekenen in de loop van de jaren zestig, te weten een meer methodische, meer (psycho)therapeutische oriëntatie, hebben gevolgen voor de verpleegkundigen. Die zich wijzigende oriëntatie wordt, voor zover dat al van elkaar losstaande gebeurtenissen zijn, onder meer bepaald door de komst van psychologen, de opkomst van de antipsychiatrie, dat wat wel de "jaren zestig" wordt genoemd en van een groep patiënten met eerder psycho-sociale dan psychiatrische problemen. Een in het oog springend gevolg van alle veranderingen is dat de hegemonie van psychiaters en verpleegkundigen niet langer meer vanzelfsprekend is.

In het veranderende domein van de sociale psychiatrie volgen de verpleegkundigen de ontwikkelingen aarzelend. Ze beginnen zich, zij het in beperkte mate en in beperkte aantallen, te richten op een nieuwe patiëntengroep, bij te scholen, te specialiseren en (psycho)therapeutisch te oriënteren. Niet alle beroepsgenoten bezien dat met instemming. De bezwaren richten zich tegen de cliëntgroep op wie de nieuwe werkwijzen zijn gericht; de verpleegkundigen zijn bezorgd dat de oorspronkelijke groep tekort gedaan zal worden. Ze zijn bovendien van mening dat de nieuwe werkwijzen niet des verpleegkundige zijn of dat ze daarvoor zelf niet de aangewezen personen zijn.

Niet helemaal duidelijk is welke gevolgen de veranderingen hebben voor de tot dan toe grote mate van autonomie van de verpleegkundigen. Het ziet ernaar uit dat ze vooralsnog voldoende ruimte vinden hun eigen gang te gaan, in elk geval de groep die het bekende voor- en nazorgwerk blijft doen. De groep die makkelijker 
met de veranderingen meegaat, geeft dan misschien zijn autonomie niet prijs, maar het is wel aannemelijk dat het werk minder "onbekeken" wordt verricht.

Binnen de verpleegkundige beroepsgroep ontstaat een zekere mate van divergentie waar het gaat om overeenstemming omtrent elkaars werkterrein en omtrent de taken die daarop verricht zouden moeten worden. Het gaat niet langer alleen maar om het buiten de inrichting houden van psychiatrische patiënten door middel van begeleiding, structurering en controle. Het gaat nu ook om het extramuraal behandelen van een groep mensen met relatief lichte problemen. De intraprofessionele ideologische en domeinconsensus is daarmee niet langer meer vanzelfsprekend. Het feit dat sommige verpleegkundigen het niet eens zijn met de veranderingen en van mening zijn dat ze er niet in mee moeten gaan, is een aanwijzing voor verminderde positieve coördinatie en evaluatie van elkaars activiteiten. De intraprofessionele coherentie van de verpleegkundigen neemt, vergeleken met de periode daarvoor, in de loop van de jaren zestig af.

Met de komst van de Riagg's in 1982 breken er turbulente tijden aan voor de verpleegkundigen, zeker voor de groep ouderen. In een zich sterk bureaucratiserende en rationaliserende omgeving wordt verwacht dat ze zich in toenemende mate richten op een cliëntgroep die ze niet de "hunne" achten. Ze worden geacht, eveneens in toenemende mate, activiteiten te verrichten waarvan ze vinden dat die niet door hen verricht kunnen of moeten worden of dat die niet ten goede komen aan hun oorspronkelijke patiëntgroep. Veranderingsgericht behandelen, individuele benadering los van de sociale context van de patiënten en psychotherapie, dat zijn de zaken waarop binnen de Riagg's de nadruk wordt gelegd. De groep voor- en nazorgpatiënten "oude stijl" wordt, althans voor een deel, uit het oog verloren. Patienten komen in toenemende mate naar de Riagg's, huisbezoeken raken in onbruik.

Zowel de leidinggevenden in de Riagg's, nu managers, als psychologen en een nieuwe generatie psychiaters, niet altijd even ervaren naar de mening van de verpleegkundigen, mengen zich nadrukkelijk in de verpleegkundige beroepsuitoefening. De autonomie van de verpleegkundigen staat in toenemende mate onder druk. Dat geldt overigens niet alleen voor het deel van de groep ouderen dat met de vernieuwingen grote moeite heeft. De bureaucratisering en de rationalisering hebben gevolgen voor alle beroepsgroepen en voltrekken zich door het hele Riaggbedrijf heen.

De nieuwe generatie verpleegkundigen heeft tegen de tijd dat de Riagg-vorming wordt ingevoerd, nog weinig historie. Ofschoon heel anders opgeleid dan hun oudere beroepsgenoten, zijn de jongeren niet onverdeeld van mening dat die opleiding voldoende voorbereiding biedt op het werk in de sociale psychiatrie. In de praktijk leren ze pas hoe ze daadwerkelijk vorm en inrichting moeten geven aan hun activiteiten. Die geluiden zijn, zoals al duidelijk is geworden, niet typerend voor de groep jongeren. Een deel van de jongeren is, evenals een deel van de ouderen, van mening dat binnen de Riagg's te weinig aandacht bestaat voor wat wel de "kansarme 
psychiatrische patiënt" wordt genoemd en, voor zover dat wel gebeurt, dat aan die aandacht niet adequaat vorm wordt gegeven. Dat deel van de jongeren maakt, naar het zich laat aanzien makkelijker dan een deel van zijn oudere collega's, gebruik van in aanmerking komende nieuwe inzichten en werkwijzen. Die nieuwe inzichten en werkwijzen moeten de patiënt expliciet zien in samenhang met zijn sociale context, dus niet als de "geïdentificeerde probleemeigenaar".

Er bestaat goed beschouwd zowel binnen de groep oudere als binnen de groep jongere verpleegkundigen voortgaande divergentie in opvattingen op een drietal onderdelen. Als eerste zijn er de patiënten waarop de aandacht zich zou moeten richten: de groep kansarme, al dan niet chronische psychiatrische patiënten versus de groep mensen met relatief lichte psychiatrische en psycho-sociale problemen. Vervolgens zijn er de activiteiten die ten behoeve van de patiënten moeten worden ontplooid: begeleiding versus behandeling/psychotherapie. Tot slot bestaat er divergentie in de visie van waaruit de werkzaamheden moeten worden verricht: de noodzaak tot het expliciet betrekken van de sociale omgeving in de benadering van de patiënt versus een geïndividualiseerde aanpak. Ideologische en domeinconsensus staan verdergaand onder druk. Datzelfde geldt voor positieve evaluatie van elkaars werkzaamheden. Die conclusie geldt bijgevolg, samenvattend, voor de intraprofessionele coherentie van de sociaalpsychiatrisch verpleegkundige beroepsgroep.

Uit het voorafgaande valt op te maken dat de mate van balans op de dimensies domeinconsensus, ideologische consensus, werkcoördinatie en positieve evaluatie van werkzaamheden, kortom de mate van intraprofessionele coherentie van de sociaalpsychiatrisch verpleegkundige beroepsgroep, slechts in beperkte mate wordt bepaald door de beroepsgroep zelf.

Aanvankelijk, als het domein van de sociale psychiatrie overzichtelijk en stabiel is, is daarmee de coherentie binnen de verpleegkundige beroepsgroep relatief hoog. Dat wordt anders als dat domein, onder invloed van een complex van factoren, aan veranderingen onderhevig raakt. Aan een relatief weinig geprofileerde en niet specialistisch opgeleide beroepsgroep worden nieuwe verwachtingen gesteld waaraan die groep, althans een deel ervan, niet kan of niet wil voldoen. De groep is niet meer, in elk geval onvoldoende, in staat zijn eigen domein succesvol te claimen en daaraan zowel praktisch als theoretisch inhoud te geven. Dat verandert vooralsnog niet als er een nieuwe beroepsopleiding tot stand komt en dat wordt nog moeilijker door en na de ingrijpende reorganisatie van de extramurale geestelijke gezondheidszorg, de Riagg-vorming.

In het volgende hoofdstuk, waarin onder meer een schets wordt gegeven van recente ontwikkelingen, zal blijken hoe belangrijk factoren en ontwikkelingen buiten de beroepsgroep zelf en/of waarop de beroepsgroep weinig invloed heeft, zijn voor de professionalisering van de sociaalpsychiatrisch verpleegkundigen. 


\section{Hoofdstuk 8}

\section{Ruim twintig jaar ontwikkelingen in het domein van de geestelijke gezondheidszorg en de sociaalpsychiatrische verpleegkunde van omstreeks 1985 tot 2008}

\subsection{Inleiding}

Zoals in het vorige hoofdstuk is gebleken, zijn ontwikkelingen en gebeurtenissen buiten de beroepsgroep van grote invloed op de sociaalpsychiatrische verpleegkunde. Met de RIAGG-vorming in 1982 wordt het tot dan toe relatief autonome domein van de sociale psychiatrie, waarin de verpleegkundigen samen met de psychiaters prominent aanwezig zijn, onderdeel van een groter organisatorisch geheel. Gevolg daarvan is onder meer dat zowel de patiëntgroep, de activiteiten die ten behoeve van de patiënten worden verricht als de werkplaats van de verpleegkundigen, veranderen. Het gaat, in tegenstelling tot wat de verpleegkundigen gewend zijn, in toenemende mate om patiënten zonder inrichtingsverleden met relatief lichte problemen die vanuit een psychotherapeutische oriëntatie worden benaderd, gericht op het verkrijgen van inzicht en de bewerkstelliging van gedragsverandering bij het individu. Plaats van handeling is de RIAGG-spreekkamer en niet meer de leefomgeving van de patiënt. Bij een deel van de oudere verpleegkundigen roepen de veranderingen weerstand op. Een ander deel ziet nieuwe mogelijkheden en past zich relatief makkelijk aan. Ook bij de nieuwe lichting verpleegkundigen, die vanaf 1974 uitstroomt uit de specialistische hogere beroepsopleiding, is verschil in opvattingen waarneembaar. Een deel van die groep past zich aan aan de manier van werken. Een ander deel is van mening dat er te weinig aandacht wordt gericht op de groep moeilijk benaderbare en moeilijk behandelbare patiënten en dat de geïndividualiseerde benadering, los van de context van de patiënt, niet geëigend is voor die groep.

$\mathrm{Na}$ de RIAGG-vorming komt er allesbehalve een einde aan de veranderingen. Daarover gaat dit hoofdstuk. Eerst worden enkele ontwikkelingen geschetst die van belang zijn voor het domein van de geestelijke gezondheidszorg. Dat domein, waarvan het intra- en extramurale subdomein langzaam in elkaar opgaan, "vermaatschappelijkt" in toenemende mate en is in afnemende mate autonoom. De overheid heeft daarin niet de enige, maar wel een doorslaggevende rol. Aan het begin van de eenentwintigste eeuw, krap 20 jaar na de RIAGG-vorming, worden er ingrijpende 
veranderingen aangekondigd die, indien ze worden gerealiseerd, een vergaande afbouw van de sectorale structuur van de tweedelijns geestelijke gezondheidszorg tot gevolg zullen hebben.

Vervolgens worden belangrijke ontwikkelingen in de sociaalpsychiatrische verpleegkunde weergegeven. De beroepsgroep blijkt nog steeds sterk te worden beïnvloed door ontwikkelingen en gebeurtenissen van buitenaf. De entree van inrichtingsverpleegkundigen in de extramurale zorg, de opheffing van de MGZ/GGZberoepsopleiding en de uitbreiding van het sociaalpsychiatrisch verpleegkundige domein met de eerstelijnsgezondheidszorg zijn daarvan goede voorbeelden. Vanaf begin van de jaren negentig nemen de verpleegkundigen, en dat is nieuw, merkbaar stelling in het domeindebat. Zij, althans de spraakmakers, kiezen voor de moeilijk benaderbare en behandelbare patiënt en voor wat wordt aangeduid als "het sociaalpsychiatrisch gedachtegoed".

Aan de betekenis van dit alles en aan de mogelijke gevolgen ervan voor de ontwikkeling van de beroepsgroep in de nabije toekomst is het laatste deel van dit hoofdstuk gewijd.

\subsection{Ontwikkelingen in de geestelijke gezondheidszorg}

\subsubsection{Patiëntenstroom}

De RIAGG's ontwikkelen zich binnen enkele jaren na oprichting tot de voornaamste verstrekkers van extramurale geestelijke gezondheidszorg in Nederland en bedienen sterk groeiende aantallen cliënten. In het eerste jaar van hun bestaan in 1982 komen er zeven op 1.000 inwoners om hulp. In 1988 is dat aantal gegroeid tot veertien op 1.000, in 1996 tot bijna zeventien op 1.000. ${ }^{399}$ Uitgedrukt in absolute getallen zijn er in 198295.000 mensen bij de RIAGG's in zorg en worden er 109.000 nieuw ingeschreven. In 1995 gaat het om respectievelijk 277.000 en 245.000 cliënten. ${ }^{400}$ De jaarprevalentie van het aantal cliënten in de hele Nederlandse geestelijke gezondheidszorg, intra- semi- en extramuraal is in 1997 naar schatting meer dan een miljoen. In 2004 en in 2006 wordt anderhalf procent van de bevolking, rond de 247.500 personen, ingeschreven bij de RIAGG's. ${ }^{401}$

Het aantal opnemingen in de algemene psychiatrische ziekenhuizen stijgt tussen 1980 en 1997 van 22.250 naar 41.440. Een groeiend deel van de opnames komt voor rekening van dezelfde patiënten. In 1997 bijvoorbeeld worden er 12.000 heropnemingen gerealiseerd. ${ }^{402}$

\footnotetext{
${ }^{399}$ Hutschemaekers, G.J.M. \& Oosterhuis, H. (2004). Psychotherapy in The Netherlands after the Second World War. Medical History, 48, 429-448, 443.

${ }^{400}$ Sociaal Cultureel Planbureau (1998). Sociaal cultureel rapport 1998. Den Haag: SCP, 310.

${ }^{401}$ Centraal Bureau voor de Statistiek (2004). Statistisch jaarboek 2004. Voorburg; Heerlen: CBS, 94. Centraal Bureau voor de Statistiek (2007). Statistisch jaarboek 2007. Voorburg; Heerlen: CBS, 81.

${ }^{402}$ Hutschemaekers, G. (2000). Wordt Nederland steeds zieker?: kengetallen en achtergrondanalyses. Maandblad Geestelijke Volksgezondheid, 55 , 314-335, 315.
} 
Ofschoon beduidend kleiner in omvang dan de psychiatrische ziekenhuizen, nemen de psychiatrische afdeling van algemene ziekenhuizen, de PAAZ-en, een niet onaanzienlijk deel van de zorgverlening in de geestelijke gezondheidszorg voor hun rekening. In 1994 worden er ruim 17.000 opnames gerealiseerd, tegenover ongeveer 36.000 in de algemene psychiatrische ziekenhuizen. Op de poliklinieken van de PAAZ-en worden in 199428.000 eerste consulten verricht. De PAAZ-poli's nemen acht procent van de totale productie van de ambulante geestelijke gezondheidszorg voor hun rekening. ${ }^{403}$

Ook de personeelsomvang van de Nederlandse geestelijke gezondheidszorg groeit. In 1989 zijn er iets meer dan 35.000 volledige arbeidsplaatsen. In 1996 zijn het er omstreeks 45.400 en de aantallen nemen daarna nog toe. ${ }^{404}$ Ondanks de personeelstoename die zich ook bij de RIAGG's voltrekt, kunnen deze instellingen de groeiende hulpvraag niet aan. Een gevolg is dat er wachtlijsten ontstaan.

\subsubsection{Psychotherapie}

In de RIAGG's neemt in korte tijd de psychotherapie een belangrijke plaats in. Het zijn de psychotherapeuten en niet de psychiaters die de toonaangevende beroepsgroep worden. ${ }^{405}$ "In the late 1980s the position of psychotherapy and psychotherapists seemed unassailable. Psychotherapists were formally recognized and the psychotherapeutic tradition dominated the RIAGG". ${ }^{406}$ Binnen de psychiatrische ziekenhuizen en meer nog binnen de psychiatrische afdelingen van algemene ziekenhuizen krijgt de psychotherapie door de jaren heen minder vaste voet aan de grond dan binnen de RIAGG's. ${ }^{407}$

In dezelfde periode gaan de psychiatrische ziekenhuizen de afdelingen voor langdurig verblijf afbouwen en vervangen door kleinschalige woonvormen op het terrein en in de regio. ${ }^{408}$ Zo ontstaat het beschermde wonen dat onder de naam Regionale Instelling voor Beschermd Wonen (RIBW) uitgroeit tot een eigenstandig deel van de geestelijke gezondheidszorg.

Omdat het aantal opnames in de psychiatrische ziekenhuizen toeneemt en het beleid erop is gericht de opnameduur zo kort mogelijk te houden, stijgt het aantal ontslagen fors. De mogelijkheden tot het verlenen van nazorg houden met die stij-

\footnotetext{
403 Jabaaij, L., \& Hutschemaekers, G. (1998). Vraag en aanbod in de Paaz: een praktijkstudie vanuit het perspectief van patiënten en behandelaars op de psychiatrische afdelingen van algemene ziekenhuizen. Utrecht: Trimbos-instituut, 3.

${ }^{404}$ Hutschemaekers, G.J.M., \& Tiemens, B.G. (2006). Het einde van de sectorale GGZ: ontwikkelingen, trends en controverses in Nederland. Tijdschrift voor Psychiatrie, 48, 27-37, 29/30.

${ }^{405}$ Met psychiaters wordt hier bedoeld: psychiaters-niet psychotherapeuten.

${ }^{406}$ Hutschemaekers, G.J.M., \& Oosterhuis, H. Psychotherapy in The Netherlands after the Second World War, 443.

${ }^{407}$ Hutschemaekers, G.J.M., \& Tiemens, B.G. Het einde van de sectorale GGZ: ontwikkelingen, trends en controverses in Nederland, 31.

${ }^{408}$ Wennink, H.J. ( 1998). De ongelukkige relatie tussen maatschappij en geestelijke gezondheidszorg: een bezinning op 25 jaar rumoer in de (sociale) psychiatrie. Maarssen: Elsevier; De Tijdstroom, 34.
} 
ging geen gelijke tred; de RIAGG's kunnen de toestroom niet aan. ${ }^{409}$ Als gevolg daarvan gaan de inrichtingen de nazorg, zij het in beperkte mate, zelf organiseren. Daartoe worden de poliklinieken uitgebreid. Desondanks ontstaat een groep patiënten die pendelt tussen (her)opname in de inrichting, de polikliniek en het RIAGG en voor wie continuïteit in de zorgverlening niet of onvoldoende wordt gerealiseerd.

\subsubsection{Poliklinieken}

In vrij korte tijd ontwikkelen de poliklinieken van de psychiatrische ziekenhuizen zich tot afdelingen voor brede extramurale hulpverlening. Ze gaan steeds meer lijken op de afdelingen voor volwassenenzorg van de RIAGG's, zowel in aantallen patiënten als in patiënttypen en in werkwijzen. "Als we de specifieke functie van de RIAGG-crisisdiensten buiten beschouwing laten (bijna 28.000 inschrijvingen in 1989) is het zeker gerechtvaardigd om in de reguliere ambulante volwassenzorg een 60-40 verdeling te postuleren. De psychiatrische poliklinieken nemen dus een aanzienlijk aantal van de extramurale zorg voor volwassenen voor hun rekening en de RIAGG heeft hier zeker geen monopoliepositie verworven". ${ }^{410}$ De RIAGG-populatie bestaat voor ongeveer de helft uit patiënten met "neurotische en psychosociale problematiek en anderzijds ernstige psychiatrie. De RIAGG-cliëntèle wijkt dus in principe niet of nauwelijks af van de patiënten van poliklinieken... De nazorgfunctie is net zo goed een taak van de RIAGG als van de polikliniek... .Ook de zorg voor chronische patiënten is niet een exclusief terrein voor de een of de ander...". ${ }^{411}$ In de poliklinieken zijn psychotherapie en methoden zoals gezinsbegeleiding, netwerkinterventies en psycho-educatie onderdeel geworden van de hulpverlening. Deze ontwikkelingen geeft de hoogleraar psychiatrie Gersons in 1995 aanleiding om te concluderen dat de psychiatrische ziekenhuizen zó ambulant werken dat de RIAGG's in feite overbodig zijn geworden. $^{412}$

\subsubsection{Biologische oriëntatie}

In de loop van de jaren tachtig, zich voortzettend in de jaren negentig doet zich in de geestelijke gezondheidszorg een belangrijke ontwikkeling voor: de wederopkomst van de biologisch georiënteerde, ook wel medische psychiatrie genoemd. Deze richting is ten gevolge van de overwegend geesteswetenschappelijke oriëntatie van de psychiatrie-opleiding rond 1960 ondergesneeuwd geraakt. ${ }^{413}$ Later, in de periode van de antipsychiatrie, is ze naar de marge van de praktijk van de geestelij-

\footnotetext{
${ }^{409}$ Ibidem.

${ }^{410}$ Beek, H. van, \& Hutschemaekers, G. (1992). De psychiatrische polikliniek voor het voetlicht. Maandblad Geestelijke Volksgezondheid, 47, 939-954, 941-942.

${ }^{411}$ Ibidem, 951.

${ }^{412}$ Boer, N. de (1995). RIAGG's hebben hun doel bereikt. De Gazet, 8, 6-8.

${ }^{413}$ Abma, R., \& Weijers, I. (2005). Met gezag en deskundigheid: de historie van het beroep psychiater in Nederland. Amsterdam: WSP, 176.
} 
ke gezondheidszorg verwezen. Toch is ze niet helemaal verdwenen, met name niet aan de universiteiten zoals die van Groningen en Utrecht. In die laatste plaats wordt Van Praag in 1978 hoogleraar biologische psychiatrie nadat hij tien jaar in Groningen heeft gewerkt. In de jaren negentig, de Decade of the Brain genoemd, neemt de belangstelling voor de biologische psychiatrie verder toe. In 1992 concludeert een door de hoofdinspecteur voor de geestelijke volksgezondheid ingestelde "Kerngroep biologische psychiatrie" dat het specialisme zowel wetenschappelijk als klinisch relevant is. ${ }^{414}$ Met het beschikbaar komen van nieuwe technieken wordt nietinvasief hersenonderzoek mogelijk naar de oorzaken van psychiatrische stoornissen. ${ }^{415}$ Van grote invloed op de medicalisering is ook het beschikbaar komen van nieuwe en snel werkzame psychofarmaca, waarvan Prozac het bekende voorbeeld is. De medicamenteuze behandeling van psychiatrische problemen krijgt daarmee een impuls. Niet enkel door de voorschrijvers, maar ook door de gebruikers worden medicijnen vanaf begin jaren negentig weer een geaccepteerd alternatief. "Veel patiënten die... behandeld werden met 'inzichtgevende' psychotherapie, waren het gebrek aan snelle resultaten beu, en grepen de komst van de nieuwe medicijnen aan om zich snel weer beter te kunnen voelen" ${ }^{416}$ Biologische psychiatrie, jaren verguisd vanwege haar vermeende reductionistische en inhumane karakter, is duidelijk terug.

Met dit alles krijgt de rol van de psychiater, die met name in de RIAGG's fors aan belang heeft ingeboet, weer meer betekenis. De psychiaters die zich vanaf de tweede helft van de jaren tachtig psychotherapeutisch zijn gaan oriënteren, zijn nu niet enkel meer op dat terrein en op het gebied van de psychiatrische diagnostiek deskundig, maar ook op het aspect van de medisch-psychofarmacologische behandeling. Ze krijgen weer een meer centrale positie als behandelcoördinator of teamleider. "Ik zie in het werk een ommezwaai van het therapeutisch denken naar het medisch denken. Er worden veel meer medicijnen voorgeschreven. In het sociaalpsychiatrische team werken we alleen maar met psychiaters samen, er zijn geen andere disciplines in het team", zo vat een sociaalpsychiatrisch verpleegkundige de situatie samen. $^{417}$

Binnen de algemene psychiatrische ziekenhuizen en vooral binnen de psychiatrische afdelingen van algemene ziekenhuizen heeft de centrale rol van de psychiaters minder ter discussie gestaan dan in de RIAGG's. Ze zijn daar door de jaren heen meer dan in de RIAGG's hun stempel op de behandelfilosofie blijven drukken en hebben er de rol van medisch specialist beter weten te behouden. ${ }^{418}$

\footnotetext{
${ }^{414}$ Ibidem, 179.

${ }^{415}$ Ibidem, 233-234.

${ }^{416}$ Ibidem, 238.

${ }^{417}$ Padt, I. van der (1999). Hoopvol bezorgd: sociaalpsychiatrische verpleegkunde van de $20^{\text {ste }}$ naar de $21^{\text {ste }}$ eeuw. Eindhoven: Nederlandse Vereniging van Sociaal Psychiatrisch Verpleegkundigen, 47.

${ }^{418}$ Hutschemaekers, G.J.M., \& Tiemens, B.G. Het einde van de sectorale GGZ: ontwikkelingen, trends en controverses in Nederland, 31.
} 


\subsubsection{Invloed van de overheid}

Een ander belangrijke ontwikkeling is de toenemende overheidsbemoeienis met de inrichting van de (geestelijke) gezondheidszorg in Nederland. Ofschoon niet pas beginnend met, is ze duidelijk herkenbaar vanaf het verschijnen van beleidsstukken zoals de Nota Geestelijke Volksgezondheid in 1971, de Structuurnota Gezondheidszorg in 1974 en de Nieuwe Nota Geestelijke Gezondheidszorg in 1984. In die laatste wordt de nadruk gelegd op kleinschaligheid en substitutie van klinische zorg door extramurale zorg. ${ }^{419}$ In wezen gaat het in het overheidsbeleid door de jaren heen om hetzelfde: "the organization of mental health care as an integrated system providing comprehensive care to a community in a circumscribed area". ${ }^{420}$

In de Beleidsvisie Geestelijke Gezondheidszorg 1999 van de minister van VWS is die lijn doorgetrokken, onder meer door nadruk te leggen op versterking van de eerstelijn voor de opvang van GGZ-problematiek, de beëindiging van de RIAGG's en de psychiatrische ziekenhuizen als aparte voorzieningen aan te kondigen, evenals een herziening van de beroepenstructuur in de GGZ. ${ }^{421}$

Opnamepreventie en -vervanging, vermaatschappelijking, continuïteit van zorg en zorgketens, zorg op maat, vraagsturing in plaats van aanbodsturing, cliëntparticipatie, volume- en kostenbeheersing, evidence based practice, het zijn onderwerpen waarop beleid wordt ingezet. Ze kunnen, voor zover er al geen overlap tussen bestaat, niet los van elkaar worden gezien. Dat wordt ook duidelijk uit maatregelen die worden genomen om de belangen van de cliënten te waarborgen. De vervanging van aanbodgestuurde door meer vraaggestuurde zorg is niet enkel ingegeven door cliëntbelangen, maar ook uit overwegingen van efficiency en beheersbaarheid. De gedachte hierachter is dat als de patiënt krijgt wat hij of zij vraagt of waaraan hij of zij behoefte heeft, het probleem snel en naar tevredenheid zal worden opgelost.

Net zoals elders in de gezondheidszorg krijgen ook in de geestelijke gezondheidszorg ontwikkelingen als objectivering en systematisering toenemende aandacht. In de diagnostiek wordt dat zichtbaar door het toenemend gebruik van de Diagnostic and Statistical Manual for Mental Diseases DSM III en volgende versies, ontwikkeld door de American Psychiatric Association. ${ }^{422}$ Er ontstaat aandacht voor het formuleren van disciplinaire en multidisciplinaire consensusdocumenten, voor standaardisering en protocollering. Evidence based medicine krijgt ook hier voet aan de grond.

\footnotetext{
${ }^{419}$ Londen, J. van (2001). Opkomst en neergang van de sociale psychiatrie: kan het boek van de sociale psychiatrie al worden gesloten en terzijde gelegd? Trimbos-lezing 2001. Utrecht: Trimbos-instituut, 15.

${ }^{420}$ Schnabel, P. (1998). Dutch psychiatry after World War II: an overview. In M. Gijswijt-Hofstra, \& R. Porter, Cultures of psychiatry and mental health care in postwar Britain and the Netherlands. Amsterdam: Rodopi, 41.

${ }^{421}$ Ministerie van Volksgezondheid, Welzijn en Sport (1989). Beleidsvisie geestelijke gezondheidszorg 1999. Den Haag: Minsterie van VWS, 5-6.

${ }^{422}$ Schnabel, P. Dutch psychiatry after World War II: an overview, 37-38.
} 


\subsubsection{Patiëntenbeweging}

Een niet te onderschatten factor die van invloed is op het domein van de geestelijke volksgezondheid is de patiënten(recht)beweging. In de loop van de jaren zijn patiënten, wellicht meer nog hun belangenbehartigers, partij geworden in het denken over en het vorm geven aan behandeling en zorgverlening. Ypsilon, de vereniging voor familieleden van mensen met schizofrenie of een psychose, is daarvan een goed voorbeeld. De vereniging heeft onder meer niet opgehouden om, jaren tegen de stroom in, te benadrukken dat het geven van (te) veel verantwoordelijkheid aan mensen met een psychose contra-effectief en in bepaalde gevallen zelfs gevaarlijk is. $^{423}$

Andere belangrijke ontwikkelingen zijn het tot stand komen van de Wet Bijzondere Opnemingen Psychiatrische Ziekenhuizen (BOPZ) in 1992 en de Wet op de Geneeskundige Behandelovereenkomst (WGBO) uit 1995. De Wet BOPZ regelt onder meer de rechten van patiënten die onvrijwillig zijn opgenomen. In de WGBO worden de relaties tussen patiënten en hulpverleners geregeld, onder andere in termen van het recht op informatie, de noodzaak van toestemming voor een bepaalde behandeling en het recht op inzage in het dossier.

Van recenter datum is het betrekken van (ex)-patiënten bij de behandeling. Als ervaringsdeskundigen worden zij ingeschakeld bij onder meer het geven van voorlichting over ziektebeelden en bij het inrichten van zorgprogramma's. De patiëntenbeweging is ook betrokken bij het tot stand komen van behandelrichtlijnen.

\subsubsection{Kritiek}

Vrijwel vanaf het begin bestaat er naast waardering voor de RIAGG's ook kritiek. ${ }^{424}$ Die kritiek bestaat er onder meer uit dat er te veel aandacht wordt besteed aan clienten met relatief lichte problematiek en aan jonge, goed opgeleide en gemotiveerde hulpvragers, yavis-cliënten (young, attractive, verbal, intelligent, successful) genoemd. Voor beide groepen is langdurige, meer fundamentele en inzichtgevende psychotherapie een veel toegepaste vorm van behandeling. Daarin komt vanaf het begin van de jaren negentig langzaam verandering. De psychotherapie komt onder druk te staan en wordt vervangen door beperkte series van frequente contacten, gericht op minder hoog opgeleide cliënten met meer ernstige problemen. Er ontstaan vormen van pragmatische, probleemgeoriënteerde psychotherapie. ${ }^{425}$ Deze worden in toenemende mate uitgevoerd door psychologen-niet psychotherapeuten en sociaalpsychiatrisch verpleegkundigen.

\footnotetext{
${ }^{423}$ Wunderink, L. (2005). Zorg met kleefkracht: over organisatie van de zorg voor mensen met ernstige psychotische stoornissen. Sociale Psychiatrie, 24 (75), 15-23, 16.

${ }^{424}$ Festen, T., \& Heringa, M. (1997). Van dichtbij en veraf: 15 jaar RIAGG/25 jaar NVAGG. Utrecht: Nederlandse Vereniging voor Ambulante Geestelijke Gezondheidszorg, 104.

${ }^{425}$ Hutschemaekers, G.J.M., \& Oosterhuis, H. Psychotherapy in The Netherlands after the Second World War, 445.
} 
Met de opkomst van de "evidence-based beweging" raakt de psychotherapie verder in de verdrukking. Uit de in 2003 afgekondigde multidisciplinaire richtlijn voor angststoornissen bijvoorbeeld zijn de meer persoonsgerichte werkwijzen zoals psychodynamische, cliëntgeoriënteerde en groepstherapieën verdwenen als gevolg van onvoldoende aangetoond effect. ${ }^{426}$ Cognitieve therapie wordt bij een gegeneraliseerde angststoornis als de meest effectieve psychologische interventie aanbevolen. ${ }^{427}$

\subsubsection{Samenwerking}

De al eerder genoemde hiaten in de continuïteit van zorg leiden tot vormen van samenwerking tussen intra- en extramurale instellingen. Er worden zorgketens gevormd die beogen te voorzien in geïntegreerde zorg. Vanaf begin jaren negentig ontstaan projecten voor psychiatrische thuiszorg. ${ }^{428}$ Zorgprogramma's worden ontwikkeld, omschreven activiteiten voor groepen hulpvragers met overeenkomstige zorgbehoeften. $^{429}$

Langzaam aan beginnen de grenzen tussen intra- en extramurale psychiatrie te vervagen. Onder druk van de landelijke overheid gaan de RIAGG's en de psychiatrische ziekenhuizen vanaf begin jaren negentig fuseren. ${ }^{430}$ Gevolg daarvan is dat aan het begin van de eenentwintigste eeuw, goed twintig jaar na de RIAGG-vorming, het merendeel van de RIAGG's en de ziekenhuizen onderdeel zijn van geïntegreerde regionale instellingen voor geestelijke gezondheidszorg. Van de 41 RIBW's maken er 14 deel uit van een geïntegreerde instelling. Tussen de hiervoor genoemde instellingen en categorale psychiatrische ziekenhuizen, psychiatrische afdelingen van algemene ziekenhuizen en overige GGZ-instellingen ontstaan allerlei vormen van samenwerking. $^{431}$

De fusies leiden weliswaar tot meer samenhang in het zorgaanbod, maar desondanks komt naar schatting een derde van de mensen met ernstige psychische problemen niet in aanraking met de geestelijke gezondheidszorg. Voor lichte en matige problemen zijn de cijfers nog hoger. ${ }^{432}$

Voor de professionals in de geestelijke gezondheidszorg betekenen al deze ontwikkelingen dat het in toenemende mate niet enkel zorginhoudelijke factoren in de meer strikte zin zijn die hun functioneren sturen. De tijd dat een psychiater, al

\footnotetext{
${ }^{426}$ Ibidem.

${ }^{427}$ Multidisciplinaire richtlijn angststoornissen, 142. www.cbo.nl 21-9-2008.

${ }^{428}$ Vesseur, J. (1997). Activiteiten van de verpleegkundige in de psychiatrisch-intensieve thuiszorg: een evaluatieonderzoek naar de PIT-projecten Maastricht en Sittard. Maastricht: Wetenschapswinkel Universiteit Maastricht, 3.

${ }^{429}$ Peters, A., Thiesen, Y., Verburg, H., Schene, A., \& Schrijvers, G. (2007). Zorgprogrammering in de GGZ zet door: de stand van zaken in 2006. Maandblad Geestelijke Volksgezondheid, 62, 500-511, 500.

${ }^{430}$ Hodiamont, P.P.G., Berting, M., \& Hezewijk, W.J.M. van (1998). Cultuurverschillen binnen een integrerende GGZ-instelling. Tijdschrift voor Psychiatrie, 40, 231-237, 231.

${ }^{431}$ GGZ-MZ: feiten en cijfers: zorgaanbod en capaciteit. www.brancherapporten.minvws.nl 01-08-2008.

${ }^{432}$ Ibidem.
} 
dan niet op basis van informatie van de verpleegkundige, de behandeling uitzet en bepaalt hoe lang die moet worden voortgezet, is, zo die ooit al op deze manier heeft bestaan, voorbij. Mutatis mutandis geldt dat ook voor andere disciplines. Dat leidt tot zorgen omdat te veel zaken buiten het contact patiënt-zorgverlener de aandacht afleiden, omdat het bovenindividuele te veel nadruk krijgt waardoor de patiënt tekort wordt gedaan. ${ }^{433}$

Dat leidt ook tot de constatering dat het "eigene" van de diagnostiek, in dit geval van de psychiatrische diagnostiek, niet meer bestaat omdat "iedere GGZmedewerker met een DSM-IV boekje op zak loopt" ${ }^{434}$ En als vraaggestuurde zorg zo ver gaat dat de cliënt zelf het best kan bepalen wat goed voor hem is, "... dan ben ik het daar niet mee eens... Als mijn deskundigheid er niet toe doet, dan zou die cliënt mij toch niet om hulp hoeven vragen?" 435

\subsubsection{Recente ontwikkelingen en plannen}

Het ziet er voorlopig niet naar uit dat de rust in het domein van de geestelijke gezondheidszorg terugkeert.

In 2002 verschijnt het advies "Zorg van velen" van de Landelijke Commissie Geestelijke Volksgezondheid. ${ }^{436}$ De commissie constateert onder meer dat ontwikkelingen in de welzijnszorg en de geestelijke gezondheidszorg onvoldoende op elkaar zijn afgestemd en dat er een te sterke en exclusieve relatie is gecreëerd tussen de institutionele geestelijke gezondheidszorg en het domein van de geestelijke volksgezondheid. Samenhangend met deze twee constateringen worden enkele aanbevelingen geformuleerd waarvan de in dit bestek meest relevante nu volgen.

De eerste aanbeveling is dat de organisatie van de geestelijke gezondheidszorg moet worden gedecategoriseerd en aansluiting moet zoeken bij voorzieningen voor welzijnszorg en algemene gezondheidszorg. Verder beveelt de commissie aan om experimenten op te zetten die zijn gericht op het ontwikkelen van een nieuw partnership tussen hulpverleners en burgers. Er dienen met voorrang nieuwe contextuele zorgarrangementen te worden ontwikkeld waarin het klassieke onderscheid tussen professionals en leken wordt doorbroken. "Dit is mogelijk door het opstellen van nieuwe opleidingsprofielen, in eerste instantie van de agogische beroepen in de ge-

\footnotetext{
${ }^{433}$ Abma, R., \& Weijers, R. Met gezag en deskundigheid: de historie van het beroep psychiater in Nederland, 184.

${ }^{434}$ Koerselman, F. (1998). Classificatie en psychotherapie. Maandblad Geestelijke Volksgezondheid, 53, 1064-1068., 1065.

${ }^{435}$ Padt, I. van der. Hoopvol bezorgd: sociaalpsychiatrische verpleegkunde van de $20^{\text {ste }}$ naar de $21^{\text {ste }}$ eeuw, 114.

${ }^{436}$ Landelijke Commissie Geestelijke Volksgezondheid (2002). Zorg van velen: eindrapport van de Landelijke Commissie Geestelijke Volksgezondheid. Den Haag: Ministerie van Volksgezondheid, Welzijn en Sport.
} 
zondheidszorg en sociaal psychiatrisch verpleegkundigen". Tot slot wordt uitbreiding van het aantal contextuele hulpverleners bepleit. ${ }^{437}$

In de reactie van de minister van Volksgezondheid, Welzijn en Sport van 2003 op het advies "Zorg van velen" wordt onder meer aangekondigd dat de geestelijke gezondheidszorg zal gaan bestaan uit twee lagen. De eerste is de geïntegreerde algemene eerstelijnszorg voor het grootste deel van mensen met psychische stoornissen. Daar wordt kortdurende generalistische hulp geboden door huisarts, maatschappelijk werker of eerstelijnspsycholoog. De tweede laag is de gespecialiseerde ambulante en klinische geestelijke gezondheidszorg. Die is er voor de behandeling van stoornissen die vanwege ernst of complexiteit niet in de eerste lijn kunnen worden behandeld en richt zich op het genezen dan wel hanteerbaar maken van psychische stoornissen. ${ }^{438}$ In deze tweede laag gaat het onder meer om de naar schatting 60.000 mensen die als gevolg van de complexiteit van hun stoornis en de daarmee gepaard gaande sociale problemen en gedragsproblemen langdurig zorg en begeleiding nodig hebben, waarvan zo'n 25.000 intensief. Doel is niet genezing en herstel, maar het bieden van zorg en begeleiding bij het leren omgaan met de beperkingen als gevolg van de stoornis. ${ }^{439}$ "Geestelijke gezondheidszorg", aldus de minster, "heeft dezelfde missie als de somatische gezondheidszorg: het behandelen van ziekten en het zoveel mogelijk beperken van de schadelijke effecten van deze ziek$t_{e n}{ }^{440}$ Die lijn wordt doorgetrokken in de brief van de minister aan de Tweede Kamer van 11 juli 2007 waarin de overheveling per 1 januari 2008 "van de geneeskundige geestelijke gezondheidszorg" van de Algemene Wet Bijzondere Ziektekosten (AWBZ) naar de Zorgverzekeringswet (ZW) wordt aangekondigd. De overheveling wordt door de minster gezien als instrument ter vergroting van de zorginhoudelijke samenhang in de hele curatieve zorg en ter bevordering van de doelmatigheid daarvan. ${ }^{441}$ Binnen de geestelijke gezondheidszorg zal dezelfde verrekeningssystematiek worden gebruikt als in de somatische gezondheidszorg, te weten die van de diagnose-behandelcombinatie, kortweg dbc genoemd.

Met de beleidsmatig-technocratische stellingname van de minister worden psychiatrische problemen op één lijn gesteld met somatische problemen en als me-

\footnotetext{
${ }^{437}$ Ibidem, 128.

${ }^{438}$ Deze maatregelen kunnen worden gezien als een concretisering van wat wordt genoemd "getrapte zorg" (stepped care): bij gelijk effect verdient de minst invasieve zorg de voorkeur.

${ }^{439}$ Ministerie van Volksgezondheid, Welzijn en Sport (2003). Brief van de Minister van Volksgezondheid, Welzijn en Sport aan de Tweede Kamer der Staten-Generaal van 28-11-2003. [Den Haag]: Ministerie van VWS, 4.

${ }^{440}$ Ibidem, 7.

${ }^{441}$ Ministerie van Volksgezondheid, Welzijn en Sport (2007). Brief van de Minister van Volksgezondheid, Welzijn en Sport aan de Tweede Kamer der Staten Generaal van 11-7-2007. Den Haag: Ministerie van VWS, 1-2.

Dit beleid bouwt in grote lijnen voort op de zogenoemde trechter van Dunning uit 1991. Uit dat model kunnen vier vragen worden afgeleid waarop keuzes in de zorg gebaseerd dienen te worden: is de zorg noodzakelijk, is ze effectief, is ze kosteneffectief en is er noodzaak tot collectieve financiering.
} 
disch in letterlijke zin gekenschetst. Dat geldt ook voor de problemen van de groep van 60.000 patiënten.

De opvattingen van de minister stroken niet met die van een deel van de sociaalpsychiatrisch verpleegkundigen. Zij zijn van mening, zoals hierna zal blijken, dat een instrumentele, diagnosegeoriënteerde, niet contextuele benadering van de groep die kan worden aangeduid als sociaal zwak met psychiatrische problemen, niet de goede benadering is. De minister gaat in zijn beleidsplannen ook niet in op de aanbevelingen uit het rapport "Zorg van velen", die inhouden dat er contextuele zorgarrangementen dienen te worden ontwikkeld en dat het aantal contextuele hulpverleners dient te worden uitgebreid.

\subsection{De sociaalpsychiatrische verpleegkunde}

\subsubsection{Groei van de beroepsgroep}

Met de groeiende vraag naar geestelijke gezondheidszorg en de groei van het aantal arbeidsplaatsen, neemt ook het aantal sociaalpsychiatrisch verpleegkundigen toe. In 1971 zijn er bij de SPD-en 491 spv-en in dienst. ${ }^{442}$ Bij de RIAGG's bestaan in 1986 $761 \mathrm{spv}$-arbeidsplaatsen. Dat aantal neemt toe tot 1.065 in $1994 .{ }^{443}$ Het totale aantal spv-en in de Nederlandse geestelijke gezondheidszorg wordt enkele jaren later geschat op 1.544. Daarvan werken er 1.225 bij de RIAGG's, waarvan 55 procent bij de afdeling volwassenenzorg, 27 procent bij de ouderenzorg, dertien procent bij de jeugdzorg en zes procent elders. Bij de APZ-en, CAD's en PAAZ-en is respectievelijk acht, vier en twee procent werkzaam. In 2004 zijn er in Nederland naar schatting 2.500 sociaalpsychiatrisch verpleegkundigen. ${ }^{444}$ De laatste schatting van 2008 komt op een aantal van 2.850 . $^{445}$

\subsubsection{Werk van de sociaalpsychiatrisch verpleegkundigen}

Uit het vorige hoofdstuk is duidelijk geworden dat zowel de cliëntgroep van de sociaalpsychiatrisch verpleegkundigen als de toegepaste manier van werken na de komst van de RIAGG's snel verandert. Dat kan voor een groot deel worden toegeschreven aan het primaat van de psychotherapie binnen de RIAGG's. Gevolg daarvan is dat de verpleegkundigen zich niet langer alleen maar richten op de moeilijk behandelbare patiënt in diens leefomgeving, de niet gemotiveerde die niet naar de

\footnotetext{
${ }^{442}$ Romme, M.A.J. (red.) (1978). Voorzieningen in de geestelijke gezondheidszorg: een gids voor consument en hulpverlener. Alphen aan den Rijn; Brussel: Samsom, 24.

${ }^{443}$ Hutschemaekers, G., \& Neijmeijer, L.(1998). Beroepen in beweging: professionalisering en grenzen van een multidisciplinaire GGZ. Utrecht; Houten: Trimbos-instituut; Bohn Stafleu Van Loghum, 168.

${ }^{444}$ Uitspraak van de voorzitter van de Nederlandse Vereniging van Sociaal Psychiatrisch Verpleegkundigen NVSPV tijdens het congres ter gelegenheid van het vijfentwintig jarig bestaan van de vereniging in december 2004.

${ }^{445}$ Koekkoek, B., Meijel, B. van, Schene, A. \& Hutschemaekers, G. (2008). Sociaal-psychiatrisch verpleegkundigen in Nederland: een enquête. Sociale Psychiatrie, 27(87), 47-56, 48.
} 
RIAGG wil of kan komen. "The social psychiatric care approach, in which social psychiatric nurses visited and supported their chronic patients, was replaced by a far more therapeutic approach in which patients had to visit the RIAGG, were social psychiatric nurses treated them with psychotherapeutic methods". ${ }^{446}$ Het ligt overigens niet voor de hand dat het gaat om psychotherapie in de meer strikte zin van het woord. De verpleegkundigen zijn daartoe niet opgeleid. Waarschijnlijker is dat ze gebruik maken van uit de psychotherapie overgenomen technieken of benaderingen. $^{447}$

Die indruk wordt bevestigd door een beroepenstudie die halverwege de jaren negentig is uitgevoerd. Daaruit blijkt dat de kerntaken van de sociaalpsychiatrisch verpleegkundigen voor het grootste deel bestaan uit het voeren van intakegesprekken, het houden van spreekuren en baliediensten, het doen van crisisinterventie en het voeren van begeleidings-en behandelgesprekken. ${ }^{448}$ De inhoud van de directe patiëntenzorg bestaat vooral uit begeleiding, gedefinieerd als het geven van steun, het bieden van structuur, het adviseren bij materiële en immateriële problemen. Daarna komen netwerkontwikkeling, netwerkondersteuning, zorgcoördinatie en het geven van advies, informatie en hulp bij het gebruik en beheren van medicijnen. Psychotherapie, omschreven als het voeren van inzichtgevende, op verandering gerichte gesprekken wordt minder frequent uitgevoerd. Datzelfde geldt voor het bieden van praktische hulp, zoals het zoeken van huisvesting en het op orde houden van financiën. ${ }^{449}$ Het therapeutische element van de werkzaamheden, zo concluderen de onderzoekers, "lijkt echter niet zozeer betrekking te hebben op het 'aanpakken' van de psychische stoornis zelf, maar op bestrijding van de psychische, sociale en lichamelijke problemen die daaruit voortvloeien". 450 Dat spoort met de in die tijd in de verpleegkundige wereld geaccepteerde opvatting dat verplegen zich niet in de eerste plaats richt op de ziekte of de stoornis van de patiënt, maar op de gevolgen daarvan voor het leven van alledag. Aan deze specifieke invulling van het beroepsdomein is onder meer invulling gegeven in Orem's Self Care Deficit Theory of Nursing, ook Theorie van Zelfzorgtekort genoemd. Uitgangspunt daarvan is dat het doen aan zelfzorg een manier is waarop mensen een gezond bestaan kunnen realiseren. Indien ze, bijvoorbeeld door ziekte of handicap, niet tot zelfzorg in staat zijn, indien er een zelfzorgtekort dreigt te ontstaan of al is ontstaan, zijn verpleegkundige

\footnotetext{
${ }^{446}$ Hutschemaekers, G.J.M., \& Oosterhuis, H. Psychotherapy in The Netherlands after the Second World War, 436.

${ }^{447}$ De term psychotherapie wordt bij voorbeeld ook gebruikt om activiteiten als gespreksvoering, directieve technieken en onderhandelen mee aan te duiden. Zie: Gersons, B.P.R. (1994). Verpleegkundige wordt casemanager: transformatie en opkomst van een "zwijgende meerderheid". Sociale Psychiatrie, 13, 36, zonder paginanummers.

${ }^{448}$ Hutschemaekers, G., \& Neijmeijer, L. Beroepen in beweging: professionalisering en grenzen van een multidisciplinaire GGZ, 174.

${ }^{449}$ Ibidem, 176.

${ }^{450}$ Ibidem, 177.
} 
interventies op hun plaats. Die interventies zijn erop gericht dat zelfzorgtekort te voorkomen, respectievelijk op te heffen of zo beperkt mogelijk te houden. ${ }^{451}$

Wat de eerder aangehaalde beroepenstudie bevestigt is dat de werkzaamheden van de verpleegkundigen zich voor het grootste deel binnen de gebouwen van de RIAGG's zijn gaan afspelen. 62 Procent van de patiëntcontacten vindt daar plaats, tegen 32 procent bij de patiënten thuis en zes procent elders. Veel van de contacten thuis komen voor rekening van de verpleegkundigen in de ouderenzorg. In de sectoren volwassenen- en jeugdzorg vindt respectievelijk achttien en veertien procent van de activiteiten plaats bij de cliënten thuis. ${ }^{452}$ Uit de studie blijkt verder dat 60 procent van de sociaalpsychiatrisch verpleegkundigen contact heeft met de cliënt zelf, negentien procent met de partner van de cliënt (vooral in de RIAGGouderenzorg), tien procent met zijn of haar gezin (met name in de RIAGGjeugdzorg). Zes procent werkt met groepen cliënten.

Cliënten waarmee de sociaalpsychiatrisch verpleegkundigen in aanraking komen zijn mensen met psychiatrische problemen en stoornissen in engere zin, zoals stemmingstoornissen, psychotische stoornissen en angststoornissen, maar ook mensen met, al dan niet in combinatie met psychiatrische problemen, onder anderen een beperkt sociaal netwerk, arbeids- huisvestings- en financiële problemen, relatie- en zingevingsvragen, beperkt of ontbrekend toekomstperspectief, problemen als gevolg van ingrijpende gebeurtenissen zoals geweld en mishandeling, problemen met het verbaliseren en het aangaan van een gesprek en mensen die relatief laag zijn opgeleid. ${ }^{453}$ Chronisch psychiatrische patiënten, en bedoeld worden waarschijnlijk mensen met manifeste, min of meer geïsoleerde psychiatrische problemen in engere zin, vormen met naar schatting vijftien procent een minderheid van de clientèle van de sociaalpsychiatrisch verpleegkundigen. ${ }^{454}$ "Vergelijken we de SPV-patiënten met de patiënten van andere hulpverleners in de RIAGG, dan blijkt dat de SPV-cliënt iemand is die er niet zozeer psychisch, maar wel sociaal en maatschappelijk slecht voor staat." ${ }^{455}$ Komen de verpleegkundigen als groep in aanraking met een breed scala aan patiënten, ook individuele verpleegkundigen kunnen met meer dan één patiëntencategorie in aanraking komen.

In 2008 is bijna 66 procent van de verpleegkundigen werkzaam binnen afdelingen voor kortdurende ambulante zorg, ongeveer 55 procent binnen afdelingen

\footnotetext{
${ }^{451}$ Brouns, G. (1993). Zelfzorgtheorie van Orem. Dwingeloo: Kavannah, 12-13.

452 Hutschemaekers, G., \& Neijmeijer, L. Beroepen in beweging: professionalisering en grenzen van een multidisciplinaire GGZ, 173.

${ }^{453}$ Wolf, J. \& Hoof, F. van (1995). De waarde van het beroep voor de GGZ: een profiel van de beroepsgroep sociaalpsychiatrisch verpleegkundigen. Sociale Psychiatrie, 14(42), 27-33, 28.

${ }^{454}$ Ibidem, 29.

${ }^{455}$ Hutschemaekers, G., \& Neijmeijer, L. Beroepen in beweging: professionalisering en grenzen van een multidisciplinaire GGZ,177.
} 
voor langdurige ambulante zorg en ongeveer 25 procent bij de ambulante crisisdienst. $^{456}$

\subsubsection{Andere verpleegkundigen in het extramurale domein}

Aan het begin van de jaren negentig ontstaat, zoals al eerder is vermeld, de psychiatrisch intensieve thuiszorg PIT. PIT past binnen de ideeën over deïnstitutionalisering en extramuralisering en is gericht op het voorkomen of verkorten van een opname in een APZ of een PAAZ. De zorgverlening is beperkt in de tijd, bijvoorbeeld maximaal drie maanden, en onder meer gericht op ADL-functies, medicatiegebruik, leren omgaan met beperkingen en het ondersteunen van eventuele huisgenoten. ${ }^{457}$ De zorg wordt verleend vanuit aan het psychiatrische ziekenhuis verbonden psychiatrisch verpleegkundigen.

Met de opkomst van de thuiszorg betreden inrichtingsverpleegkundigen, en dat is, anders dan incidenteel, nog niet eerder vertoond, het domein van de sociaalpsychiatrisch verpleegkundigen. Dat valt niet onverdeeld positief bij de laatsten. "Het zit hem er niet in waar je het doet, maar hoe je het doet. Het is misschien wel gericht op het voorkomen van opname of het verkorten van een opname in de kliniek, maar de manier waarop het gebeurt heeft niets met de sociaalpsychiatrische denkwijze te maken". ${ }^{458}$ De sociaalpsychiatrisch verpleegkundigen betwijfelen of de inrichtingsverpleegkundigen, gewend als ze zijn om in teamverband te werken, wel voldoende in huis hebben om zelfstandig te opereren. De inrichtingsverpleegkundigen voelen zich ondergewaardeerd, omdat zij het dagelijkse werk doen dicht bij de patiënten, maar belangrijke beslissingen aan de sociaalpsychiatrisch verpleegkundigen moeten overlaten die de rol van teamcoördinator vervullen. ${ }^{459}$

Het is zeer wel denkbaar dat met het beleid dat door de minister van VWS in 2003 is geformuleerd, het aantal verpleegkundigen, afkomstig uit de psychiatrische ziekenhuizen, in de extramurale geestelijke gezondheidszorg zal toenemen. Daarmee is de extramurale psychiatrische verpleegkunde in afnemende mate het exclusieve domein van sociaalpsychiatrisch verpleegkundigen. Zoals de grenzen tussen intra- en extramurale psychiatrie vervagen, zo gebeurt dat ook met de grenzen tussen intra- en extramurale psychiatrische verpleegkunde.

\footnotetext{
${ }^{456}$ Koekkoek, B., Meijel, B. van, Schene, A., \& Hutschemaekers, G. Sociaal-psychiatrisch verpleegkundigen in Nederland: een enquête. Sociale Psychiatrie, 27(87), 47-56, 51-52.

Kortdurende zorg = korter dan twee jaar. Langdurige zorg = langer dan twee jaar.

${ }^{457}$ Vesseur, J. Activiteiten van de verpleegkundige in de psychiatrisch intensieve thuiszorg: een evaluatieonderzoek naar de PIT-projecten in Maastricht en Sittard, 4.

${ }^{458}$ Padt, I. van der. Hoopvol bezorgd: sociaalpsychiatrische verpleegkunde van de $20^{\text {ste }}$ naar de $21^{\text {ste }}$ eeuw, 143.

${ }^{459}$ Brink, C.J. (2000). Gekwalificeerd voor de psychiatrische thuiszorg: een onderzoek naar de inzetbaarheid van de intramuraal werkende, inservice opgeleide psychiatrisch verpleegkundige in de psychiatrisch intensieve thuiszorg. Doctoraalscriptie Gezondheidswetenschappen, afstudeerrichting Verplegingswetenschap, Universiteit Maastricht. Maastricht: Universiteit Maastricht, 12.
} 
Deze "domeininvasie" is een voorbeeld van een ontwikkeling waarop de sociaalpsychiatrisch verpleegkundige beroepsgroep geen invloed heeft. Ze komt tot stand door ontwikkelingen die zich voltrekken buiten de beroepsgroep om, wordt in elk geval niet door de groep geëntameerd en, zoals hiervoor is gebleken, ook niet met veel enthousiasme ontvangen.

\subsubsection{Sociaalpsychiatrisch verpleegkundigen in de eerste lijn}

De tweede ontwikkeling is de betrokkenheid van sociaalpsychiatrisch verpleegkundigen bij de eerstelijns gezondheidszorg. Die betrokkenheid komt voort uit de in de Beleidsvisie Geestelijke Gezondheidszorg 1999 aangekondigde maatregelen van de minister van VWS om de eerstelijns geestelijke gezondheidszorg, waarin huisartsen, algemeen maatschappelijk werkenden en eerstelijnspsychologen de kerndisciplines zijn, te versterken. Consultatie door werkers uit de tweedelijns GGZ is daartoe het middel.

In een evaluatie over de periode 2000 tot 2004 is onder meer bekeken welke tweedelijns werkers bij de consultatie betrokken zijn. In alle jaren doen de verpleegkundigen, in opklimmende mate, tussen de 58 en 76 procent van de consultaties. Het aandeel van de psychiaters daalt, evenals dat van de psychologen. Dat van overigen, bijvoorbeeld de jeugdzorg, is vrijwel stabiel. Ter concretisering: in 2004 wordt van de 9.774 geregistreerde consultaties 76.1 procent verricht door sociaalpsychiatrisch verpleegkundigen, 7.7 procent door psychologen, 4.3 procent door psychiaters en 11.8 procent door overigen. ${ }^{460}$

Maar het ziet ernaar uit dat het niet blijft bij consultatie alleen. Er zijn vanaf 2001 zogenoemde Regionale Ondersteunings Structuren ROS-en gerealiseerd waarin de ondersteuning van de eerstelijn door de tweedelijn wordt geformaliseerd. In het verlengde daarvan, en gestimuleerd door de minister van VWS, is per 1 januari 2008 de functie van Praktijkondersteuner Huisarts-GGZ, de POH-GGZ, tot stand gekomen. Het doel van de functie wordt omschreven als "het ondersteunen van de huisarts bij het verlenen van zorg aan patiënten die met psychische en/of psychosociale problemen een beroep doen op de huisarts" ${ }^{461}$ De praktijkondersteuner kan, binnen de ruimte die door de huisarts wordt gegeven, behandelen, met uitzondering van medicamenteuze therapie. ${ }^{462}$ Kandidaten voor het vervullen van de nieuwe functie zijn naar verwachting sociaalpsychiatrisch verpleegkundigen en maatschappelijk werkenden. De beroepsvereniging van de verpleegkundigen V\&VN-SPV en die van de maatschappelijk werkenden NVMW hebben op basis van die verwachting

\footnotetext{
${ }^{460}$ Verhaak, P.F.M., Zantinge, E.M., Vonk, E., Voordouw, I., \& Veen, C. v.d. (2005). GGZ-consultaties aan de eerstelijnszorg (registratie 2000-2004). Utrecht: NIVEL, 20.

${ }^{461}$ Venneman, B. \& Verberk, F. (2008). De sociaalpsychiarisch verpleegkundige in de eerstelijns GGZ. Sociale Psychiatrie, 27(87), 7-14, 12.

${ }^{462}$ Bouwmans, M. (2008). Praktijkondersteuner GGZ: belangrijke motor voor ontwikkeling eerstelijns GGZ. Sociale Psychiatrie, 27(87), 56-58, 57.
} 
een functieprofiel opgesteld. ${ }^{463}$ De verpleegkundige beroepsvereniging geeft met haar aandeel in het opstellen van het functieprofiel een signaal dat ze mogelijkheden ziet voor de uitbreiding van de rol van sociaalpsychiatrisch verpleegkundigen in de eerstelijn. Dat signaal kan worden opgevat als een domeinclaim. Datzelfde kan ook worden afgeleid uit het document "Transparant aanbod Sociaal Psychiatrisch Verpleegkundigen in de eerste lijn: modulen als bouwstenen voor de hulpverlening". Daarin wordt gedetailleerd omschreven wat de verpleegkundigen te bieden hebben. ${ }^{464}$

Of verpleegkundigen werkelijk als praktijkondersteuner aan de slag zullen gaan is nog onduidelijk. De ontwikkelingen verkeren nu nog in een vroeg stadium. ${ }^{465} \mathrm{Be}$ langrijk zal de houding van de huisartsen zijn. Ze lijken zich terughoudend op te stellen nu deze nieuwe functie geen inkomsten voor hen zelf genereert. Een gratis verpleegkundige, gedetacheerd vanuit de tweedelijns GGZ, heeft vooralsnog de voorkeur. ${ }^{466}$ Van belang ook zal zijn de bereidheid van zorgverzekeraars om de functie van praktijkondersteuner te financieren. De verpleegkundigen zelf ten slotte doen er ook toe. "Of de SPV erin slaagt een eigen positie te gaan innemen is volgens mij ook afhankelijk of zij de routines van de tweedelijns GGZ achter zich kan laten. En of ze bereid is om met luide stem haar sociaalpsychiatrische uitgangspunten te laten horen of te laten doorklinken in de manier van werken". ${ }^{467}$

De activiteiten van de sociaalpsychiatrisch verpleegkundigen in de eerstelijn tot nu toe kunnen worden gezien als een uitbreiding van het beroepsdomein, te meer omdat zo'n 70 procent van de patiënten waarmee de verpleegkundigen in aanraking komen, niet wordt verwezen naar de tweede lijn. Deze groep behoeft naar men aanneemt geen specialistische zorg en valt dus niet binnen het aandachtsgebied van de verpleegkundigen tot dan toe. Deze domeinuitbreiding is een goed voorbeeld van een ontwikkeling waarin de beroepgroep nauwelijks zeggenschap heeft en in elk geval niet zelf in gang heeft gezet.

\subsubsection{Aandacht voor het sociaalpsychiatrische gedachtegoed}

Als derde ontwikkeling kan worden beschouwd de weer groeiende en steeds terugkerende aandacht binnen de sociaalpsychiatrisch verpleegkundige beroepsgroep voor wat de verpleegkundigen zelf "het sociaalpsychiatrische gedachtegoed" noemen en voor wat wel de "zorgwekkende zorgmijder" wordt genoemd. Vanaf begin jaren negentig van de twintigste eeuw verschijnen er publicaties die daarop betrek-

\footnotetext{
${ }^{463}$ Functieprofiel startdocument PraktijkOndersteuner Huisartsenzorg POH-GGZ 2008.

${ }^{464}$ Scholte, M. \& Brink, C. (2008). Transparant aanbod Sociaal Psychiatrisch Verpleegkundigen in de eerste lijn: modulen als bouwstenen voor de hulpverlening. Utrecht: Movisie.

${ }^{465} \mathrm{Nu}$ is oktober 2008.

${ }^{466}$ Bouwmans, M. Praktijkondersteuner GGZ: belangrijke motor voor ontwikkeling eerstelijns GGZ, 58.

${ }^{467}$ Venneman, B. De sociaalpsychiatrisch verpleegkundige in de eerstelijns GGZ, 14.
} 
king hebben. "Bemoeizorg: ongevraagde hulp voor psychotische patiënten", een proefschrift uit 1993, geschreven door een sociaalpsychiatrisch verpleegkundige, is daarvan een voorbeeld. ${ }^{468}$

In het artikel "Verpleegkundigen, verantwoordelijke partners in de GGZ" uit 1994 wordt gesteld dat sociale psychiatrie niet gelijk staat aan extramuraal werken. "Het gaat om de cliënt in zijn maatschappelijke en sociaal-culturele context, hun behoeften en de directe omgeving: familie, sociale netwerk, professionele netwerk. Er wordt uitgegaan van actieve bemoeienis van de hulpverleners met allerlei risicogroepen. Ook heeft men aandacht voor de sociaal-culturele context waarin psychiatrische problematiek zich ontwikkelt en poogt men maatschappelijke uitstoting en marginalisering van bepaalde groepen tegen te gaan. Sociale psychiatrie onderscheidt zich door een kritische houding van andere vormen van psychiatrie, het ziektemodel staat niet voorop. Ook beschouwt men het als een taak van de sociale psychiatrie het publiek bewust te maken van de maatschappelijke invloed van proble$m n^{\prime}{ }^{469}$ In "Tussen bondgenootschap en 'deskundologie': verkenning van uitgangspunten voor methodiekontwikkeling in de sociaalpsychiatrische verpleegkunde" wordt een pleidooi gehouden voor een behoeftegeoriënteerde in plaats van een diagnosegeoriënteerde benadering in de sociaal- psychiatrische verpleegkunde. ${ }^{470}$

Van later datum zijn het boek "Van bemoei- naar groeizorg: methodieken voor de OGGZ" uit $2000^{471}$ en het artikel "Sociale psychiatrie als referentiekader voor de sociaalpsychiatrische verpleegkunde". ${ }^{472}$ Ook het in onderhavige studie aangehaalde boek "Hoopvol bezorgd: sociaalpsychiatrische verpleegkunde van de $20^{\text {ste }}$ naar de $21^{\text {ste }}$ eeuw" past, voor een deel althans, in deze serie evenals in het artikel "Creativiteit in knellende omstandigheden: omgaan met knellende omstandigheden in de zorg voor kwetsbare mensen". ${ }^{473}$ Tot slot is het boek "Sociale psychiatrie: visie, theorie en methoden van een maatschappelijk georiënteerde psychiatrie", onder redactie van vier sociaalpsychiatrisch verpleegkundigen en een sociaalpsychiater, relevant. ${ }^{474}$ Daarin wordt onder meer het ideaaltypische sociaalpsychiatrische werk-

\footnotetext{
${ }^{468}$ Henselmans, H. (1993). Bemoeizorg: ongevraagde hulp voor psychotische patiënten. Delft: Eburon.

${ }^{469}$ Onderwater, K., Padt, I. van der, \& Leeuw, M. de (1999). Verpleegkundigen, verantwoordelijke partners in de GGZ. Maandblad Geestelijke Volksgezondheid, 54, 369-375, 372.

${ }^{470}$ Schout, G. (1998). Tussen bondgenootschap en 'deskundologie': verkenning van uitgangspunten voor methodiekontwikkeling in de (sociaal) psychiatrische verpleegkunde. Maandblad Geestelijke Volksgezondheid, 53, 1222-1234.

${ }^{471}$ Lohuis, G., Schilperoort, R. \& Schout, G. (2000). Van bemoei- naar groeizorg: methodieken voor de OGGZ. Groningen: Wolters-Noordhoff.

${ }^{472}$ Venneman, B. \& Padt. I. van der (2001). Sociale psychiatrie als referentiekader voor de sociaalpsychiatrische verpleegkunde. Sociale Psychiatrie, 20(61), 7-17.

${ }^{473}$ Lohuis, G., Polstra, L., \& Schout, G. (2004). Creativiteit in knellende omstandigheden: omgaan met knellende omstandigheden in de zorg voor kwetsbare mensen. Amsterdam: SWP.

${ }^{474}$ Onderwater, K., Padt, I. van der, Romme, M., Venneman, B., \& Verberk, F. (red.) (2004). Sociale psychiatrie: visie, theorie en methoden van een maatschappelijk georiënteerde psychiatrie. Utrecht: Lemma. De redacteuren maken deel uit van de in 2002 gestarte Strategiegroep Sociale Psychiatrie die zich tien jaar de tijd heeft gegeven om de "het uitgebreide kennisdomein van de sociale psychiatrie bij elkaar te
} 
proces als een fasenmodel weergegeven, niet zijnde een voorgeprogrammeerd stappenplan. "Het model is een pleidooi om, in contrast met de huidige resultaatgerichte en instrumenteel-technische zorg, ruimte te maken en te houden voor een cliëntgericht, persoons- en behoeftegeoriënteerde professionele aanpak van complexe sociale en zorgsituaties; dat is sociale psychiatrie" ${ }^{475}$

In de hiervoor geschetste ontwikkeling heeft de beroepsgroep, althans een deel ervan, in belangrijke mate een eigen aandeel. Het is de vraag of en hoe deze keuze, gegeven de ontwikkelingen en gangbare opvattingen binnen de (geestelijke) gezondheidszorg waartegen ze zich afzet, in de praktijk concreet kan worden gemaakt.

\subsubsection{Het verpleegkundige opleidingslandschap}

De vierde ontwikkeling betreft het opleidingslandschap. In 1998 is de opleiding Verpleegkundig specialist GGZ gestart. Toelaatbaar tot de opleiding zijn verpleegkundigen met een registratie volgens artikel 3 van de wet BIG, opgeleid op HBO-niveau, met vier tot vijf jaar relevante werkervaring in de GGZ. De opleiding is expliciet bedoeld om verpleegkundig specialisten op te leiden die zowel klinisch als ambulant inzetbaar zijn bij diverse doelgroepen. ${ }^{476}$ Het is niet denkbeeldig dat naast verpleegkundigen uit de psychiatrische ziekenhuizen ook afgestudeerden van deze opleiding actief gaan worden op het domein dat altijd het spv-domein is geweest. Dat wordt binnen de beroepsgroep gezien als een risico. "De kans bestaat dat de verpleegkundig specialist de SPV zal vervangen daar waar deze een leidende rol speelt in het ambulante veld, en dat de psychiatrisch verpleegkundige met aanvullende training en de HBO-opgeleide verpleegkundigen de SPV-en elders overbodig maken. Terwijl de psychiaters een nieuwe beroepsidentiteit ontlenen aan het benadrukken van de biologische aspecten van het vak, profileert de verpleegkundig specialist zich in de breedte. In dat veld wordt de plaats voor de ambulant werkende SPV onduidelijk en onderscheidt hij zich niet meer van de transmuraal werkende psychiatrisch verpleegkundige... De psychiaters verliezen de sociale context uit het oog, de verpleegkundig specialist wordt dusdanig breed opgeleid dat elke sociaalpsychiatrische specificiteit verloren gaat". 477

Een volgende, ingrijpende gebeurtenis in het opleidingsstelsel is het besluit tot beëindiging van de beroepsopleiding, de opleiding MGZ/GGZ, door de minister van OC\&W in 2002. De laatste diploma's zijn in 2007 uitgereikt. Op initiatief van de NVSPV en in samenwerking met enkele hogescholen bestaat er vanaf 2006 de mogelijkheid om de nieuwe, niet door de overheid gefinancierde opleiding Post-HBO SPV

brengen, te integreren, uit te breiden en wetenschappelijk te onderzoeken", zoals is vermeld op blz. 9 van het boek.

${ }^{475}$ Ibidem,79.

${ }^{476}$ Coördinerend Orgaan Nascholing en Opleiding in de GGZ (2006). GGZ verpleegkundige specialist. [S.I.]: Coördinerend Orgaan Nascholing en Opleiding in de GGZ.

${ }^{477} \mathrm{Kool}, \mathrm{J}$. (2000). De psychiater, de verpleegkundig specialist en de sociale psychiatrie: wie bewaakt de ontwikkeling van dit vakgebied? Maandblad Geestelijke Volksgezondheid, 55, 1033-1041, 1035. 
te volgen. De eerste diploma's zijn inmiddels uitgereikt. De opleiding wordt geacht de verpleegkundigen de mogelijkheid te bieden om "... de plaats in te nemen in het hart van de GGZ... te werken voor en met de groep mensen die buiten de boot dreigen te vallen en in hun eigen omgeving in een (dreigend) sociaal isolement terecht komt, kwetsbaar is op vele fronten, maar tegelijkertijd ook een gelukkig leven willen hebben". 478

Andere nieuwe opleidingen waarvan afgestudeerden kunnen instromen in het veld van de extramurale geestelijke gezondheidszorg zijn de Master Advanced Nursing Practice GGZ en de Master Evidence Based Practice/Sociale Psychiatrie. Omdat de twee laatsten ook toegankelijk zijn voor studenten met een andere opleiding dan de Post-HBO SPV, dus voor niet-sociaalpsychiatrisch verpleegkundigen, voldoet een diploma op zichzelf niet aan de voorwaarden voor registratie als sociaalpsychiatrisch verpleegkundige in het in 2003 ingestelde SPV-register. ${ }^{479}$ De beroepsgroep erkent afgestudeerden enkel om het feit dat ze een diploma hebben van deze opleidingen, niet als lid van de groep.

\subsection{Conclusies en discussie}

Het domein van de geestelijke gezondheidszorg blijft in de jaren na de RIAGGvorming in 1982 sterk groeien. Zowel intra-, semi- als extramuraal neemt het aantal cliënten toe. De jaarprevalentie van gebruikers in deze drie sectoren samen bedraagt in 1997 naar schatting meer dan een miljoen. De RIAGG's nemen het leeuwendeel van de cliënten voor hun rekening, gevolgd door de APZ-en en de PAAZ-en. Ook in de jaren na 1997 zet de groei door.

Met het groeiende aantal cliënten neemt ook het aantal hulpverleners toe. De Nederlandse geestelijke gezondheidszorg telt in 1989 ruim 35.000 volledige arbeidsplaatsen, in 1996 omstreeks 45.400 en de aantallen blijven daarna groeien. De RIAGG's kunnen de stijgende hulpvraag niet aan, met wachtlijsten als gevolg.

Naast deze domeinuitbreiding kan een wijziging in opvatting omtrent de inhoud van de behandeling worden geconstateerd. In de RIAGG's, in mindere mate in de psychiatrische ziekenhuizen en de PAAZ-en, wordt vrijwel vanaf het begin psychotherapie de toonaangevende manier van werken en worden psychotherapeuten de toonaangevende beroepsgroep. Met de psychotherapeutische oriëntatie binnen de RIAGG's verandert ook de cliëntpopulatie. In toenemende mate komen patiënten met psycho-sociale problemen in zorg die voor psychotherapie ontvankelijk zijn, relatief goed opgeleid en in elk geval niet met zware en ontregelende psychiatrische beelden. De rol van de psychiaters binnen de RIAGG's, voor zover ze zich niet ook psychotherapeutisch gaan oriënteren, neemt in belang af.

\footnotetext{
${ }^{478}$ Venneman, B, (2005). SPV op koers: prelude op de toekomst. Sociale Psychiatrie, 24(76), 23-31, 26.

${ }^{479}$ www.venvn-spv.nl 14-08-2008
} 
Deze veranderingen blijven niet beperkt tot de extramurale geestelijke gezondheidszorg. Ook in het intramurale domein, meer bepaald de APZ-en, doen zich veranderingen voor. Een belangrijke ontwikkeling met betrekking tot de inhoud van de behandeling is de beperking van de opnameduur. Langdurige opnames worden als contra-effectief beschouwd. Zo kort als het kan, niet langer dan noodzakelijk wordt het devies. Het aantal kortdurende opnames neemt toe en als gevolg daarvan het aantal ontslagen. Omdat door de RIAGG's niet voldoende in nazorg aan de ontslagen patiënten wordt voorzien, worden de poliklinieken van de psychiatrische ziekenhuizen uitgebreid. Daar doet zich al gauw een vergelijkbare ontwikkeling voor als in de RIAGG's: psychotherapie wordt de toonaangevende werkwijze die in toenemende wordt toegepast op een groep patiënten die lijkt op die bij de RIAGG's. Gevolg is dat de poliklinieken steeds meer gaan lijken op de afdelingen voor volwassenenzorg van de RIAGG's. Een ander gevolg is dat patiënten met meer complexe problemen van zorg verstoken blijven, in elk geval dat continuïteit van zorg voor deze groep niet is gewaarborgd.

De wederopkomst van de biologische of medische psychiatrie is een ontwikkeling op behandel-ideologisch gebied die voor het hele domein van de geestelijke gezondheidszorg belangrijk is omdat zij juist weer een rem wordt op de groei van de psychotherapie. Vooral in de jaren negentig neemt deze stroming aan betekenis toe. Het beschikbaar komen van een nieuwe generatie werkzame psychofarmaca en de bereidheid van patiënten om deze te gebruiken, dragen daaraan bij. Gevolg is onder meer dat de rol van de psychiaters als medisch-specialist weer in belang toeneemt. Gevolg is ook dat langdurende inzichtgevende vormen van psychotherapie, waarvan de effectiviteit niet langer wordt aangenomen, onder druk komen te staan. De "klassieke" psychotherapeuten verliezen daarmee voor een groot deel hun rol en verleggen hun activiteiten naar privépraktijken.

Ook los van het beschikbaar komen van de nieuwe medicijnen wordt de langdurende psychotherapie ingeruild voor meer cognitieve, pragmatische en probleemgeoriënteerde werkwijzen. Daarnaast, maar wel in samenhang met de hernieuwde medicalisering, voltrekt zich een andere belangrijke behandelinhoudelijke wijziging in de geestelijke gezondheidszorg, met name binnen de RIAGG's. Die wijziging is overigens niet beperkt tot de geestelijke gezondheidszorg. Net zoals in de somatische gezondheidszorg ontstaat er toenemende aandacht voor objectivering, systematisering en rationalisering. Evidence based practice is daarvan een voorbeeld.

Het overheidsbeleid vertoont eveneens kenmerken van rationalisering. Het in de jaren zeventig ingezette beleid, gericht op regionalisering en vermaatschappelijking, lees bereikbaarheid en continuïteit, en op volume- en kostenbeheersing, wordt onverkort doorgezet. Mede daardoor ontstaan er steeds meer vormen van samenwerking tussen de psychiatrische ziekenhuizen en de RIAGG's, waardoor de grenzen tussen beide instellingen gaan vervagen. Vanaf het begin van de jaren negentig komt het fusieproces tussen RIAGG's en ziekenhuizen op gang en ontstaan er 
regionale instellingen voor geestelijke gezondheidszorg. Zo'n tien jaar later wordt de ontmanteling van die grote instellingen aangekondigd. De geestelijke gezondheidszorg zal zich voor een deel gaan afspelen in de eerstelijnsgezondheidszorg en voor een ander, gespecialiseerd deel, in de tweedelijns intra- of extramurale gezondheidszorg.

De overheid heeft onder andere door wet- en regelgeving mede vorm gegeven aan de toenemende invloed van de patiënten(recht)beweging op het domein van de geestelijke volksgezondheid. De Wet BOPZ en de WGBO van respectievelijk 1992 en 1994 zijn daarvan voorbeelden. De groeiende invloed van de patiënten en/of hun belangenbehartigers kan voor een aanzienlijk deel ook worden toegeschreven aan de niet aflatende inspanningen van met name de belangenbehartigers, gericht op overheid en hulpverleners.

In het zich uitbreidende domein van de extramurale geestelijke gezondheidszorg neemt de groep sociaalpsychiatrisch verpleegkundigen door de jaren heen in omvang toe. Het aantal verpleegkundige formatieplaatsen groeit van 761 in 1986 tot 1065 in 1994. Enkele jaren later wordt het totale aantal geschat op 1544. Daarvan werken er 1225 bij de RIAGG's, waarvan 55 procent in de volwassenenzorg, 27 procent in de zorg voor ouderen, dertien procent in de jeugdzorg en zes procent elders. Bij APZ-en, CAD's en PAAZ-en is veertien procent werkzaam. In 2008 wordt het totale aantal verpleegkundigen geschat op 2850.

De ontwikkelingen binnen het domein van de extramurale geestelijke gezondheidszorg zijn van grote invloed op de verpleegkundigen. Zo gaat de opkomende psychotherapeutische oriëntatie niet aan hen voorbij. Ze worden dan wel geen psychotherapeut en kunnen daartoe niet worden opgeleid, maar nemen wel psychotherapeutische inzichten en benaderingswijzen over. De verpleegkundigen richten zich, zoals andere werkers binnen de RIAGG's, op de groeiende groep cliënten met psycho-sociale en levensproblemen. Niet de leefomgeving van de patiënten is de werkplek van de verpleegkundigen, maar het RIAGG. Bijna tweederde van de contacten met patiënten vindt daar plaats. De aandacht voor oorspronkelijke clientèle, bestaande uit patiënten met een inrichtingsverleden en aangevuld met een groep sociaal weinig redzamen met gedragsproblemen, raakt steeds meer op de achtergrond, maar verdwijnt niet helemaal. Vanaf het begin van de RIAGG-vorming is er een aantal verpleegkundigen dat aandacht blijft houden voor genoemde categorie patiënten en erop wijst dat de vigerende behandelideologie voor deze groep niet tot een adequate benadering leidt. Datzelfde gebeurt als in de jaren negentig de meer medisch-biologische behandeloriëntatie ontstaat. Voornaamste punten van kritiek van de verpleegkundigen zijn de medicalisering van de problemen en de geindividualiseerde benadering van de patiënten zonder het betrekken van de context daarbij. Met de voortgaande systematisering en protocollering van de behandeling tenslotte wordt volgens de verpleegkundigen onvoldoende tegemoet gekomen aan 
dat wat de patiënten nodig hebben en dat wat sociale psychiatrie beoogt: cliëntgerichte en gecontextualiseerde aanpak van zorgproblemen.

De opkomst van de psychiatrisch intensieve thuiszorg PIT, begin jaren negentig, is een voorbeeld van de al genoemde vermaatschappelijking van de geestelijke gezondheidszorg. Het ontstaan van deze transmurale vorm van zorgverlening is om drie redenen belangrijk voor de groep sociaalpsychiatrisch verpleegkundigen. De eerste is dat het extramurale verpleegkundige domein wordt uitgebreid. Dat roept bij de sociaalpsychiatrisch verpleegkundigen weinig reacties op. De tweede reden is dat dit domein nu niet meer het exclusieve domein van de sociaalpsychiatrisch verpleegkundigen is. Dat roept weerstand op bij de sociaalpsychiatrisch verpleegkundigen. De derde reden ten slotte is dat bij de komst van de inrichtingsverpleegkundigen commentaar wordt gegeven van ideologische aard. Die verpleegkundigen brengen hun intramurale oriëntatie mee en die strookt niet met wat het sociaalpsychiatrische gedachtegoed wordt genoemd.

lets vergelijkbaars gebeurt er naar aanleiding van de ontwikkelingen in het opleidingsstelsel. Met het opheffen van de specialistische MGZ/GGZ-opleiding en de komst van de opleidingen Verpleegkundig Specialist GGZ, Master Advanced Nursing Practice en Master Evidence Based Practice/Sociale Psychiatrie dreigt de sociaalpsychiatrische oriëntatie van de verpleegkundigen op het extramurale domein te worden aangetast. De op initiatief van de beroepsvereniging NVSPV gestarte opleiding Post-HBO SPV kan worden gezien als een poging die ontwikkeling een halt toe te roepen.

In hoofdstuk zeven is vastgesteld dat er binnen de sociaalpsychiatrisch verpleegkundige beroepsgroep divergentie in opvattingen bestaat zowel met betrekking tot domein als ideologie. Die vaststelling kan worden gehandhaafd.

Er is een groep die zeer uitgesproken inzet op het werken met al dan niet chronische patiënten met complexe problemen. Daarnaast is er de minder duidelijk uitgesproken groep die het "reguliere" RIAGG-werk doet dat zich voor een groot deel afspeelt in de volwassenen- en ouderenzorg en voor een kleiner deel in de jeugdzorg. Tot slot is er de groep die, naast het verrichten van de reguliere werkzaamheden, actief is in de consultatieve sfeer in de eerstelijnszorg. ${ }^{480}$ Tot de patiëntgroep waarvoor ze daar actief zijn, behoren merendeels mensen zonder ernstige problemen waarvan de behandeling in die eerstelijn kan worden voortgezet. ${ }^{481}$ De groep die inzet op het werken met de chronische patiënten kiest voor wat kan worden aangeduid als de rehabilitatie-benadering. Niet zozeer verandering of genezing is het doel, maar herstel, het op een zo volwaardig en humaan mogelijke manier invul-

\footnotetext{
${ }^{480}$ Voor zover bekend zijn er geen verpleegkundigen alleen maar in de eerste lijn actief. Dezelfde verpleegkundigen zijn dus in twee, wellicht in drie settings werkzaam.

${ }^{481}$ De relatief kleine aantallen verpleegkundigen die op andere plekken werken, bijvoorbeeld psychiatrische afdelingen van algemene ziekenhuizen en de verslavingszorg, worden hier verder buiten beschouwing gelaten.
} 
ling geven aan het leven, mét alle beperkingen, rekening houdend met en gebruik makend van de context. De activiteiten van de groep die het reguliere RIAGG-werk blijft doen, kunnen het best worden omschreven als laag tot matig complexe begeleiding van mensen met matig ernstige psychiatrische en psycho-sociale problemen. De activiteiten zijn gericht op het oplossen van problemen. Van de groep die actief is in de eerstelijn kunnen de werkzaamheden worden omschreven als diagnostisch en consultatief van aard. Het werken in de eerstelijns gezondheidszorg kan worden beschouwd als een domeinuitbreiding, die binnen de beroepsgroep geen discussie oproept en als vanzelfsprekend wordt geaccepteerd.

Samenvattend kan worden gesteld dat binnen de beroepsgroep van de sociaalpsychiatrisch verpleegkundigen van nu, goed 25 jaar na de RIAGG-vorming, minder domein- en ideologische consensus bestaat dan voorheen. Als complicerende factor komt daar nog bij dat het domein niet langer het exclusieve werkterrein van de sociaalpsychiatrisch verpleegkundigen is, maar dat er ook andere verpleegkundigen op het domein actief zijn en nog zullen worden.

De conclusie die opgaat voor de domein- en ideologische consensus kan ook worden getrokken met betrekking tot de positieve evaluatie van elkaars werkzaamheden en bijgevolg dus van de intraprofessionele coherentie. Op deze beide kenmerken bestaat er meer divergentie dan voor de RIAGG-vorming. Hiermee is niet gezegd dat die divergentie enkel kan worden toegeschreven aan ontwikkelingen binnen de beroepsgroep zelf. De voortdurende ontwikkelingen in aangrenzende beroepsgroepen en in de geestelijke gezondheidszorg als systeem zijn van zeer grote invloed. In Abbott's terminologie vertaald: het zijn met name inter- en metaprofessionele factoren die van invloed zijn op de professionalisering van de sociaalpsychiatrische verpleegkunde. In hoofdstuk negen wordt daaraan verder aandacht besteed.

Wat de voorgenomen decategorisering van de tweedelijns geestelijke gezondheidszorg gaat betekenen voor de sociaalpsychiatrisch verpleegkundigen is moeilijk te zeggen. Voor de groep verpleegkundigen in de "reguliere" sectoren volwassenen-, ouderen- en jeugdzorg van de RIAGG's, is de situatie onduidelijk. Indien de plannen worden gerealiseerd, dan zal de tweedelijn in omvang afnemen. Of dat consequenties zal hebben voor arbeidsplaatsen, en zo ja voor welke, is niet goed te overzien.

Het is de vraag of de sociaalpsychiatrisch verpleegkundigen in de toekomst een plek in de eerstelijns geestelijke gezondheidszorg zullen hebben en welke die zal zijn. In de beleidsbrief van de minister uit 2003 komen ze niet voor. Als centrale beroepsgroepen worden genoemd huisartsen, maatschappelijk werkenden en eerstelijnspsychologen. De voortgaande professionalisering van die groepen op het gebied van diagnostiek van en interventies bij geestelijke gezondheidsproblemen zou de consultatiefunctie van de verpleegkundigen wel eens overbodig kunnen maken. 
Wat de ontwikkelingen op het gebied van de praktijkondersteuning huisartsenzorg zullen brengen is, zoals al aangegeven, nog niet duidelijk.

Op het eerste oog ziet het ernaar uit dat een deel van de rond 2.850 sociaalpsychiatrisch verpleegkundigen kan worden ingezet in de door de minister van VWS in 2003 voorgestelde gespecialiseerde geestelijke gezondheidszorg bij een deel van de naar schatting 60.000 chronische patiënten met complexe problemen. ${ }^{482}$ Domeinconsensus, beter gezegd het gebrek aan domeinconsensus tussen de minister en de verpleegkundigen hoeft hier geen breekpunt te zijn. Dat ligt anders waar het gaat om ideologische consensus. De groep van 60.000 , althans een deel daarvan, bestaat uit mensen die ook wel psychisch gehandicapt worden genoemd, "zelden hun hele leven als 'ziek' zijn te bestempelen hoewel er nooit helemaal 'niks aan de hand' is". ${ }^{483}$ Het is de groep die om allerlei wel of niet aan elkaar gerelateerde redenen, sociaal en maatschappelijk weinig zelfredzaam is. Die redenen kunnen variëren van "bijkomende" kenmerken van psychiatrische problematiek ${ }^{484}$, al dan niet in combinatie met het gebruik van middelen, tot het stuk gelopen zijn op voor buitenstaanders wellicht triviale gebeurtenissen en omstandigheden. Het lukt deze mensen niet om basale bestaansvoorwaarden, te weten het hebben van werk en inkomen, het hebben en onderhouden van betekenisvolle relaties en het vorm geven aan vrijetijdsbesteding, in bevredigende mate te realiseren. ${ }^{485}$ Ze zijn, niet allemaal en niet allemaal in gelijke mate, bij tijden zichzelf en de omgeving tot last.

De aanbevelingen uit het rapport "Zorg van velen" omtrent contextualisering van de zorg, het opheffen van het klassieke onderscheid tussen hulpvragers en hulpverleners en het uitbreiden van het aantal contextuele hulpverleners lijken de groep verpleegkundigen op het lijf te zijn geschreven. Onduidelijk is of en in hoeverre die aanbevelingen door de overheid worden overgenomen en zo ja, hoe daaraan concreet vorm zal worden gegeven. Het is de vraag of het in de plannen van de minister niet vooral gaat om een verandering van het gezondheidszorgsysteem in plaats van een verandering van zorgmethoden. De door de minster gebruikte omschrijving van de missie van de geestelijke gezondheidszorg geeft alle aanleiding tot het stellen van die vraag. Daar liggen klaarblijkelijk ideologische verschillen van inzicht tussen de minister en de verpleegkundigen.

\footnotetext{
${ }^{482}$ Er worden in verschillende rapporten verschillende cijfers genoemd. Die zijn voor een deel terug te voeren op verschil in definiëring, voor een deel op de manier waarop onderzoeken zijn uitgevoerd. $\mathrm{Er}$ wordt bijvoorbeeld een aantal van 72.000 genoemd in G. de Wilde (red.) (2002), Erbij horen: advies taskeforce vermaatschappelijking geestelijke gezondheidszorg. Den Haag: Ministerie van VWS, 17.

${ }^{483}$ Ibidem, 7.

${ }^{484}$ Als voorbeeld: nogal eens zijn psychische symptomen van psychiatrische beelden, zoals hallucinaties bij schizofrenie, beter te reguleren dan de "meer onveranderlijk aanwezige achtergrond van problemen in het contact, in het automatische sociale functioneren, de problemen met het uitvoeren van complexe plannen en het tekort aan innerlijk drijvende kracht die maakt dat we ergens achteraan gaan... .". Wunderink, L. Zorg met kleefkracht: over de organisatie van de zorg voor mensen met ernstige psychische stoornissen. Sociale Psychiatrie, 24(75), 15-23, 17.

${ }^{485}$ Wilde, G. de (red.) Erbij horen: advies taskeforce vermaatschappelijking geestelijke gezondheidszorg, 18.
} 
Het is ook niet denkbeeldig dat contextuele zorg en begeleiding voortgaand geprotocolleerd zullen gaan gebeuren en dat er ook hier om evidence gevraagd gaat worden. Voor de overheid zijn deze vormen van rationalisering immers onder meer bruikbaar als beheersinstrument, voor de sector geestelijke gezondheidszorg zijn het welkome middelen om de kwaliteit van interventies aan te tonen en daarmee de legitimering van de sector. De sociaalpsychiatrisch verpleegkundigen in kwestie zetten zich af tegen instrumentalisering en protocollering. Ze vinden dat dat niet past en niet werkt bij de patiëntgroep waarop ze zich willen richten. Ook hier zitten de sociaalpsychiatrisch verpleegkundigen en de overheid ideologisch gezien niet op één lijn. Datzelfde geldt voor de sociaalpsychiatrisch verpleegkundigen en andere belangrijke spelers op het domein van geestelijke gezondheidszorg zoals psychiaters, inrichtingsverpleegkundigen, verpleegkundig specialisten en zorgverzekeraars.

Vooruitkijkend is voorlopig niet zozeer de vraag aan de orde of er voor sociaalpsychiatrisch verpleegkundigen van vandaag ruimte is op het domein van de extramurale (geestelijke) gezondheidszorg, maar hoe die ruimte gaat worden ingevuld. De ontwikkelingen van de afgelopen ruim vijfentwintig jaar overziend geven alle aanleiding te concluderen dat de verpleegkundigen zelf in het beantwoorden van die vraag geen doorslaggevend aandeel zullen hebben. Er zijn te veel zaken aan de orde waarop zij weinig of geen invloed hebben.

Het is goed voorstelbaar dat extramuraal geestelijke gezondheidszorgverpleegkundigen actief zullen zijn binnen drie subdomeinen: de generalistische eerstelijn, de specialistische tweedelijn en het gebied van de tertiaire preventie. Binnen die drie subdomeinen kunnen vooralsnog, zoals nu ook het geval is, sociaalpsychiatrisch verpleegkundigen actief zijn, zij het niet exclusief. De voortgaande instroom van de groep die tot voor enkele jaren inrichtingsverpleegkundigen werd genoemd, maar nu wordt aangeduid als basisverpleegkundigen, en van de groep verpleegkundig specialisten, lijkt evenwel onontkoombaar. De groep die zich tot nu toe sociaalpsychiatrisch verpleegkundige noemt zal daarmee op termijn onder die naam van het toneel verdwijnen. Formeel, volgens de wet, bestaat de titel al niet meer.

Wat dat gaat betekenen voor het in de praktijk brengen van wat met een weerbarstige term het sociaalpsychiatrische gedachtegoed wordt genoemd, is moeilijk te zeggen. Voor de weerbarstige problemen van een groep psychiatrische patiënten kan dat gedachtegoed niettemin het optimale en daarmee gepaste ideologische kader zijn. 


\section{Hoofdstuk 9}

\section{Conclusie en discussie}

\section{$9.1 \quad$ Inleiding}

Dit laatste hoofdstuk begint met een samenvattende weergave van de bevindingen van deze studie. Onderscheiden worden het ontstaan van de sociale psychiatrie tot omstreeks 1940, de uitgroei van omstreeks 1940 tot omstreeks 1985 en de ontwikkelingen van omstreeks 1985 tot heden. Voordat deze laatste periode wordt weergegeven worden als onderbouwing en verbijzondering van de Nederlandse situatie de ontwikkelingen in de provincie Limburg samenvattend gepresenteerd. Dat gedeelte strekt zich uit over de periode 1938 tot 1973.

Daarna worden de bevindingen geformuleerd in termen van Abbott's ideeën over professionalisering en in termen van de van Benson afgeleide ideeën omtrent intra- en interprofessionele coherentie. Het op pagina 143 gepresenteerde schema vat de ontwikkelingen in het domein van de sociale psychiatrie en de ontwikkelingen in en tussen de belangrijke beroepsgroepen die in dat domein actief zijn, samen. Er worden vijf periodes onderscheiden, te weten de periode tot omstreeks 1940, de periode van omstreeks 1940 tot begin jaren zestig, daarna de perioden van begin jaren zestig tot begin jaren zeventig, begin jaren zeventig tot omstreeks 1985 en, tot slot, de periode van omstreeks 1985 tot heden. De aangebrachte indeling is gebaseerd op het gedurende deze studie ontstane inzicht dat die periodes in termen van Benson's uitgangspunten als min of meer af te bakenen episodes kunnen worden beschouwd.

Vervolgens wordt kort aandacht besteed aan de situatie anno 2008. Tot slot worden enkele methodologische, inhoudelijke en afsluitende opmerkingen gemaakt.

\subsection{Het ontstaan van het domein van de sociale psychiatrie tot omstreeks 1940}

Aan het begin van de twintigste eeuw is het domein van de psychiatrie in de Verenigde Staten, Duitsland en Nederland voornamelijk beperkt tot inrichtingen. Die zijn vanaf omstreeks 1850 in aantal en in omvang fors gegroeid. De groei kan enerzijds worden verklaard door een grote stijging van het aantal opnames, niet enkel bestaande uit psychiatrische patiënten, maar ook uit groepen maatschappelijk onaangepasten. Anderzijds kan de groei worden verklaard door het feit dat de behandeling van de patiënten nauwelijks effectief is. Grote groepen onvrijwillig opgenomen 
mensen verblijven in overvolle inrichtingen waar de hygiëne te wensen overlaat en waar agressie, dwang en drang aan de orde van de dag zijn.

In dat psychiatrische domein zijn twee beroepsgroepen actief bij de behandeling en de verzorging van patiënten. De ene groep bestaat uit artsen, al dan niet opgeleid tot zenuwarts of psychiater. De andere groep bestaat uit voorlopers van wat nu verpleegkundigen zijn: zaalknechten en zaalmeiden genoemd.

Het aanzien van beide beroepsgroepen is laag en hun kennisgebieden zijn nauwelijks tot niet ontwikkeld. De psychiaters komen veelal niet verder dan het stellen van diagnoses en het bieden van somatisch zorg aan de vele lichamelijk zieken. De niet geschoolde zaalmeiden en zaalknechten zijn vooral bezig met het handhaven van basale hygiëne en van rust en orde. Aan het einde van de eeuw komen op initiatief van de psychiaters verpleegkundige beroepsopleidingen tot stand. De inhoud ervan is in hoge mate somatisch georiënteerd en gericht op het aandragen van informatie ten behoeve van de psychiatrische diagnostiek.

Begin twintigste eeuw gaat de psychiatrie haar domein uitbreiden, over de muren van de inrichtingen heen. De verklaring daarvoor ligt in een combinatie van factoren. De eerste is dat industrialisatie, urbanisatie en migratie een maatschappelijke dynamiek tot gevolg hebben die volgens velen tot sociale ontwrichting leidt en om ingrijpen vraagt. De tweede factor bestaat uit inzichten uit de sociologie en de psychologie die ertoe leiden dat menselijk gedrag niet enkel als biologisch gedetermineerd wordt gezien, maar dat ook de omgeving kan bijdragen aan het ontstaan en het in stand houden van gedrag en gedragsproblemen. Die omgeving dient bij het voorkomen en oplossen van de problemen te worden meegenomen. De weinig succesvolle intramurale psychiatrie, de nauwelijks hanteerbare situatie in de inrichtingen en de sterk stijgende kosten ten slotte vormen de laatste factor. Er zijn, kort samengevat, redenen om tot het verleggen van de aandacht over te gaan én er zijn nieuwe mogelijkheden om daaraan invulling te geven.

Voor de psychiatrie ontstaan zo twee nieuwe opties. De ene optie is de mogelijkheid om bij te dragen aan de preventie van problemen door de aandacht te vestigen op zaken zoals kinderarbeid, prostitutie en alcoholisme en aan vroegtijdige interventie. Dat wordt vanaf omstreeks het midden van de jaren twintig het aandachtsgebied van de beweging van de psychohygiëne. De andere optie is het aanpakken van bestaande problemen, te weten de nauwelijks succesvolle behandeling van grote groepen patiënten in overvolle inrichtingen en de daarmee gepaard gaande kosten én het voorbereiden op ontslag. Dat wordt het aandachtsgebied van de sociale psychiatrie. Naast de beweging van de psychohygiëne en de sociale psychiatrie blijft de inrichtingspsychiatrie bestaan. Er ontstaat zo een driedeling in de wereld van de geestelijke gezondheidszorg: de psychiatrische inrichtingen voor de intramurale behandeling, de voor- en de nazorg voor extramurale behandeling en de psychohygiëne voor de aanpak van sociale problemen. 
In het domein van de sociale psychiatrie zijn vanaf het begin in alle drie de landen twee beroepsgroepen prominent actief. In de Verenigde Staten zijn het psychiaters en maatschappelijk werkenden, in Duitsland en Nederland zijn het psychiaters en verpleegkundigen.

Maatschappelijk werkenden spelen in de Verenigde Staten al vanaf het eind van de negentiende eeuw een actieve en herkenbare rol in de zorg voor psychiatrische patiënten. Zij worden vanaf het begin van de twintigste eeuw door de artsen en psychiaters ingeschakeld bij het verzamelen van informatie over sociale factoren ten behoeve van de medische diagnostiek en de behandeling. Tegelijkertijd moet beïnvloeding van sociale factoren door de maatschappelijk werkenden ertoe leiden dat gezondheidsproblemen effectiever kunnen worden aangepakt.

Vanaf het begin van de twintigste eeuw ontwikkelen de maatschappelijk werkenden eigen opleidingen en vanaf omstreeks 1910 een eigen methodiek. Die is gericht op het tot stand brengen bij de patiënt van inzicht in problemen en vervolgens op verandering of aanpassing. Dezelfde methodiek maakt het ook mogelijk om gericht informatie te verzamelen ten behoeve van de psychiaters. Samen met de psychiaters ontwikkelen de maatschappelijk werkenden in 1918 een nieuwe opleiding. Het begin daarvan is een markeringspunt in het ontstaan van het nieuwe, vooralsnog kleine specialisme psychiatrisch-sociaal werk. De beroepsgroep professionaliseert vervolgens snel. Er worden leerboeken geschreven, er wordt een beroepsvereniging opgericht en er ontstaan opleidingen aan colleges en universiteiten.

Door de samenwerking met de psychiaters verliest het maatschappelijk werk weliswaar gedeeltelijk zijn eigenstandigheid, maar krijgt het ook de kans om aan de eigen methodiek, het social casework, invulling te geven. De psychiatrisch-sociaal werkenden vervullen in nauwe samenwerking met de psychiaters een rol die de laatsten niet in staat zijn te vervullen omdat ze dat getalsmatig niet waar kunnen maken en omdat ze er niet voor zijn opgeleid.

De aanvankelijk sociale oriëntatie verschuift in de loop van de jaren twintig naar een meer psychologische/psychodynamische oriëntatie. Daarmee komen de psychiatrisch-sociaal werkenden in de loop van de tijd ver af te staan van de meer sociaalpsychiatrische nazorgpraktijk. Ze vinden elders emplooi, bijvoorbeeld in de child guidance clinics. Met de voortgaande professionalisering wendt de beroepsgroep zich voor een deel af van zijn oorspronkelijke doelgroep, te weten opgenomen en ontslagen psychiatrische patiënten.

In Duitsland en Nederland betrekken de psychiaters verpleegkundigen bij hun sociaalpsychiatrische activiteiten.

De aanzetten tot extramurale psychiatrische zorg in Duitsland vanaf omstreeks 1910 worden door de Eerste Wereldoorlog onderbroken. Daarna worden met name vanuit de inrichtingen nazorgactiviteiten georganiseerd. Deze zorg is in hoge mate 
inrichtingsvervangend en structurerend en controlerend van aard. Ze wordt gerealiseerd door inrichtingsverpleegkundigen die laag zijn opgeleid, in elk geval niet gericht op sociaalpsychiatrische of maatschappelijke zorgverlening. In hun opvattingen en werkwijzen worden ze sterk gestuurd door de psychiaters. Hetzelfde kan worden gezegd van de maatschappelijk werkenden die in steden, na beperkte psychiatrische scholing, worden ingezet.

In Nederland ontwikkelt de sociale psychiatrie zich in het begin uitgaande van het grootstedelijke en particuliere initiatief, later van de psychiatrische inrichtingen en kruisverenigingen. Ook hier betrekken de psychiaters verpleegkundigen, aanvankelijk wijkverpleegkundigen, bij hun activiteiten. De wijkverpleegkundigen worden beperkt psychiatrisch geschoold. Aan hen wordt, naast assistentie van de psychiater op het consultatiebureau, een rol toebedacht in het vroegtijdig opsporen van psychiatrische problematiek. Daarmee is de sociale psychiatrie aanvankelijk voor een deel, althans in aanzet, gericht op preventie.

Vanaf 1926 gaan de inrichtingen over tot het instellen van nazorgdiensten, ook buitendiensten genoemd. Deze diensten zijn geënt op de diensten zoals die in Duitsland zijn opgezet. Kleine aantallen psychiaters en kleine aantallen inrichtingsverpleegkundigen houden consultatiebureau en leggen grote aantallen huisbezoeken af. De werkzaamheden van de buitendiensten hebben grotendeels het karakter van nazorg en kunnen als structurerend en controlerend worden aangemerkt. Ze zijn vooral gericht op het geven van aanwijzingen aangaande het leven van alledag van patiënten en mensen in hun directe omgeving en op naleving daarvan.

Als vanaf 1934 de GG\&GD-en in de grotere steden zich op extramurale zorg gaan richten, verandert er niet veel. Ook nu worden grote aantallen huisbezoeken afgelegd door kleine aantallen verpleegkundigen en kleine aantallen psychiaters. Nieuw is dat het voorkomen van opnames, voorzorg genoemd, onderdeel uitmaakt van de activiteiten. Dat neemt niet weg dat het werk het karakter heeft van maatschappelijke dienstverlening, met als doel het aantal psychiatrische opnames te verminderen, in elk geval niet te laten toenemen en dat ook hier structurering en controle belangrijke werkkenmerken zijn.

Binnen het domein van de Nederlandse sociale psychiatrie zijn twee beroepsgroepen, te weten verpleegkundigen en psychiaters, prominent aanwezig. De veelal in deeltijd werkende psychiaters leiden de diensten, houden consultatiebureau, verwijzen patiënten en doen, in beperkte mate, huisbezoeken. De overwegend voltijds aangestelde verpleegkundigen assisteren bij de spreekuren en leggen grote aantallen huisbezoeken af. Sociaalpsychiatrisch geschoold zijn zowel de psychiaters als de verpleegkundigen niet. Ze functioneren op basis van persoonlijk inzicht en opgedane ervaringen. De psychiatrie kent geen specialisme sociale psychiatrie. De opleiding B-nazorg voor de verpleegkundigen die in 1937 op initiatief van de psychiaters tot stand komt, is zeer praktijkgeoriënteerd met een nadruk op niet-psychiatrische on- 
derwerpen. Begin jaren veertig zijn er 49 gediplomeerden. De klinische oriëntatie van de verpleegkundigen is nog sterk.

Tegen de achtergrond van globaal gesproken overeenkomstige maatschappelijke en beroepsinhoudelijke vraagstukken en ontwikkelingen in de Verenigde Staten, Duitsland en Nederland nemen de psychiaters initiatieven die leiden tot zorgverlening buiten de muren van de inrichtingen. Daarmee ontstaat een nieuw, in omvang beperkt domein in de gezondheidszorg, de sociale psychiatrie. Het is, met andere woorden, een samengaan van meta- en interprofessionele factoren dat de aanleiding vormt tot het ontstaan van het nieuwe domein.

De zenuwartsen-psychiaters, die, voor zover al als zodanig opgeleid, biologischorganisch zijn georiënteerd, hebben weliswaar ideeën en idealen, maar ze hebben noch de kennis en de vaardigheden, noch zijn ze voldoende in aantal om er handen en voeten aan te geven. Ze hebben anderen nodig om mede vorm en invulling te geven aan de activiteiten. In de Verenigde Staten zijn het maatschappelijk werkenden, in Duitsland en Nederland verpleegkundigen die door de psychiaters worden binnengehaald op het nieuwe domein. De verklaring voor dat verschil in keuze van de psychiaters kan worden gegeven tegen de achtergrond van verschillen die er, ondanks de overeenkomsten, bestaan tussen de Verenigde Staten enerzijds en Duitsland en Nederland anderzijds.

In de Amerikaanse samenleving zijn de maatschappelijke problemen urgenter dan op het Europese vasteland. Meer dan in Duitsland en Nederland vervult in de aanpak daarvan de filantropie, niet de overheid, een grote rol. De invloed van sociologie en psychologie op de psychiatrie is in Amerika groter dan in Duitsland en Nederland. De Amerikaanse samenleving is in het algemeen pragmatischer en meer probleemoplossend georiënteerd dan de Duitse en de Nederlandse. Dat alles verklaart waarom de psychiatrie in de Verenigde Staten, althans de voorhoede ervan, dynamischer is dan de psychiatrie in Duitsland en Nederland, die eerder beschouwend en filosoferend kan worden genoemd. De Amerikaanse psychiatrie gebruikt de sociale omgeving niet enkel als verklaring voor het ontstaan van psychiatrische problemen, maar ook bij het daadwerkelijke oplossen en voorkomen ervan. Het is daarom dat de Amerikaanse psychiaters kiezen voor maatschappelijk werkenden. De laatsten hebben zich bovendien al geprofileerd in de zorg voor psychiatrische patiënten. Dat gegeven speelt mee bij de keuze van de psychiaters. De maatschappelijk werkenden beschikken over kennis en vaardigheden die de psychiaters niet hebben.

De psychiaters in Duitsland en Nederland zijn, vergeleken met hun Amerikaanse collega's, eerder behoudend. Ze denken en werken vanuit een individualistisch, inrichtingspsychiatrisch perspectief en zijn meer gericht op aanpassing dan op verandering en op het daadwerkelijk betrekken van omgevingsfactoren bij de behandeling van patiënten. Verpleegkundigen passen goed in deze oriëntatie. Hun denken 
en handelen wordt meer dan dat bij de maatschappelijk werkenden in de Verenigde Staten het geval is, bepaald door de psychiaters. Ze hebben nog geen eigen kennisdomein ontwikkeld. Op professionaliseringskenmerken zoals een eigen beroepsopleiding en een beroepsorganisatie blijven ze vooralsnog achter bij de psychiatrischsociaal werkenden in de Verenigde Staten. Dat neemt niet weg dat de verpleegkundigen al gauw de spil van de nazorg zijn. Ze doen het overgrote deel van het werk. Het kan niet anders dan dat ze, weliswaar binnen de kaders die de psychiaters aangeven, de ruimte hebben om naar eigen inzicht te handelen en om hun eigen werkwijzen te ontwikkelen. Vooralsnog leidt dat niet tot waarneembare explicitering van en reflectie op de eigen werkzaamheden.

\subsection{De uitgroei van de sociale psychiatrie van omstreeks 1940 tot omstreeks 1985}

Het tijdvak van ongeveer 1940 tot omstreeks 1985 kan worden gekenmerkt als een periode van toenemende omvang, dynamiek en complexiteit. Dat geldt zowel voor de inrichtingspsychiatrie als voor de sociale psychiatrie.

De inrichtingspsychiatrie herstelt zich langzaam van de gevolgen van de Tweede Wereldoorlog. Nog steeds is de behandeling weinig succesvol. Daarin komt evenwel een doorbraak met de introductie van werkzame psychofarmaca halverwege de jaren vijftig. Patiënten worden beter benaderbaar. Het aantal gevallen van dwangbehandeling, evenals de duur daarvan, neemt af. Er worden hier en daar aanzetten gegeven tot nieuwe behandelvormen zoals individuele psychotherapie en sociotherapie. Te weinig en onvoldoende geschoold personeel maakt echter dat deze laatste ontwikkeling zich slechts langzaam doorzet.

In de loop van de jaren zestig worden ingrijpender veranderingen merkbaar. De gemiddelde opnameduur van patiënten loopt onder meer door het gebruik van de psychofarmaca terug. Met de invoering van de Algemene Wet Bijzondere Ziektekosten (AWBZ) in 1967 worden de kosten van langdurige opnames vergoed, waardoor de financiële middelen groeien en de personeelstekorten worden ingelopen.

Belangrijk ook is de opkomst van de kritische of antipsychiatrie in de tweede helft van de jaren zestig. Er wordt scherpe kritiek geuit op de medische oriëntatie van de psychiatrie en op de inhumaan genoemde omstandigheden in de inrichtingen. Binnen die inrichtingen ontstaan grote verschillen van inzicht en niet zelden forse conflicten aangaande de behandeling van en de omgang met de patiënten. Patiënten dienen niet langer als ziek te worden beschouwd maar als mensen met problemen die zelf in hoge mate verantwoordelijk zijn voor het oplossen daarvan.

In de jaren zeventig wordt de invloed van de overheid op de gang van zaken in de inrichtingen duidelijk herkenbaar. De nadruk wordt gelegd op een bereikbaar en samenhangend geheel van intra- en extramurale voorzieningen en op versterking van de extramurale psychiatrie. Er wordt een begin gemaakt met de afbouw van de 
psychiatrische inrichtingen. Ongeveer tegelijkertijd, vanaf begin jaren zeventig, groeit bij de inrichtingen het aantal poliklinieken. De poli's voorzien voor een deel in nazorg aan ontslagen patiënten, maar richten zich in toenemende mate op de behandeling van een groep die overeenkomt met de patiënten van de afdelingen voor volwassenenzorg van wat vanaf 1982 de Riagg's gaan heten: de Regionale Instellingen voor Ambulante Geestelijke Gezondheidszorg. In de Riagg's zijn ondergebracht de Medisch Opvoedkundige Bureaus, De Bureaus voor Levens- en Gezinsvragen en de Sociaal Psychiatrische Diensten. In de diensten zijn de voor- en nazorgfuncties opgegaan.

Bij de voor- en nazorg, voor zover verbonden aan de psychiatrische inrichtingen, is vanaf begin jaren veertig een proces van verzelfstandiging begonnen dat in de loop van de jaren vijftig vrijwel is voltooid. Omdat de inrichtingen niet voor een afgebakend verzorgingsgebied werken, is de bereikbaarheid van patiënten bemoeilijkt en wordt de kwaliteit van de geboden zorg onvoldoende geacht. Gemeentes en provincies, die de nazorg financieren, zijn gebaat bij kwaliteit van zorg omdat daardoor het aantal opnames kan worden verlaagd of verkort. Het is dus een samengaan van inhoudelijke en financiële overwegingen dat de ontkoppeling van de buitendiensten en de inrichtingen kan verklaren. De voor- en nazorgdiensten van de inrichtingen worden ondergebracht bij provinciale, regionale en plaatselijke samenwerkingsverbanden en stichtingen. Met de al bestaande gemeentelijke nazorgdiensten, psychiatrische inrichtingen, vrijgevestigde zenuwartsen, huisartsen en rust- en pensiontehuizen op levensbeschouwelijke basis, vormen ze een lappendeken aan voorzieningen. De inrichtingen zorgen voor de intramurale behandeling, de nazorgdiensten voor de extramurale nazorg, de vrijgevestigde psychiaters en de huisartsen verzorgen de medicamenteuze behandeling extramuraal. In dat complexe geheel van instellingen en personen is het moeilijk om regie te voeren. De samenwerking blijft veelal beperkt tot vrijblijvende afspraken omtrent opname- en ontslagprocedures. Het geheel wordt nog gecompliceerder als de druk op de nazorgdiensten toeneemt door een groeiend aantal ontslagen uit de inrichtingen als gevolg van het gebruik van psychofarmaca. Niet zelden worden er patiënten ontslagen zonder dat de nazorginstanties daarin zijn gekend, en opnames, noodzakelijk geacht volgens dezelfde diensten, worden niet altijd gerealiseerd.

Het werk in de voor- en nazorg wordt rond 1960 nog steeds gedaan door psychiaters en verpleegkundigen. Ofschoon de organisatorische scheiding tussen de inrichtingen en de nazorg een feit is, zijn het grotendeels aan inrichtingen verbonden of uit de inrichting afkomstige psychiaters die de nazorgdiensten leiden en de psychiatrische inbreng leveren. De verpleegkundigen hebben eveneens voor het merendeel hun opleiding gehad in de inrichtingen en zijn, ook indien ze de B-nazorg hebben gedaan, sterk individueel, toezichthoudend en structurerend gericht. De nazorgpsychiatrie is in hoge mate een verlengde van de inrichtingspsychiatrie en daarin komt pas eind jaren zestig, begin jaren zeventig verandering. 
Voor het zover is kunnen er nog vier belangrijke beïnvloedende factoren worden vermeld. De eerste is de rijkssubsidieregeling voor Sociaal-Psychiatrische Diensten in 1961. Die houdt in dat de rijksoverheid 40 procent van de personeelslasten voor haar rekening neemt. Het gevolg van deze regeling is dat de diensten zich uitbreiden en dat de ontstane scheefgroei in beschikbare middelen tussen verschillende diensten, althans voor een deel, ongedaan wordt gemaakt. Mede als gevolg van de verbeterde financiële situatie kunnen de diensten zich richten op een nieuwe groep vrijwillige patiënten, mensen zonder ernstige of acute psychiatrische beelden, die gebaat zijn bij langdurige begeleiding en ondersteuning.

De tweede belangrijke factor is de komst van de psychologen. Die kan worden verklaard tegen de achtergrond van het inzicht dat niet enkel ernstige psychopathologie, maar ook levensproblemen tot ernstig disfunctioneren kunnen leiden en bijgevolg behandeling behoeven. De al eerder genoemde verruimde financiële mogelijkheden dragen evenzeer bij aan de komst van de nieuwe beroepsgroep.

Het derde belangrijke gegeven is de kritiek van de antipsychiatrie die, vorm krijgend in de tweede helft van de jaren zestig, ook aan de sociale psychiatrie niet voorbij gaat. Er wordt aandacht gevraagd voor de invloed van sociaalmaatschappelijke en interpersoonlijke factoren op het ontstaan en in stand houden van psychiatrische problemen en voor een actievere rol van de patiënten bij het oplossen daarvan. Verantwoordelijkheid en motivatie van patiënten worden kernbegrippen. Daarbij past inzichtgevende en op verandering gerichte behandeling en in betrekkelijk korte tijd worden psychotherapeutische behandelvormen, waarbij de psychologen actief betrokken zijn, de prominente werkwijze. De voor- en nazorg oude stijl raakt op de achtergrond, zonder echter helemaal te verdwijnen.

Belangrijk, als vierde factor, is de financiering van extramurale geestelijke gezondheidszorg vanaf 1971 via de AWBZ. Die maakt het mogelijk dat het domein van de sociale psychiatrie in omvang toeneemt. Daarmee nemen ook aantallen psychiaters, psychologen en verpleegkundigen toe. De verpleegkundigen blijven de grootste beroepsgroep. Voor die beroepsgroep krijgen de veranderende opvattingen omtrent wenselijk geachte behandeling langzaam aan consequenties waar het gaat om de aard en de concrete invulling van de dagelijkse werkzaamheden. Dat er veranderingen gaande zijn wordt ook duidelijk uit de ontwikkelingen in de verpleegkundige opleiding zoals die vanaf begin jaren zestig vorm krijgen.

De bestaande opleiding B-nazorg die aan verpleegkundigen wordt aangeboden vanaf 1937 wordt niet langer een goede basis geacht voor de verpleegkundige beroepsuitoefening in de extramurale zorg. In 1961, 1964 en 1969 presenteren verschillende commissies voorstellen voor nieuwe opleidingen. In het tot stand komen van deze voorstellen hebben de psychiaters c.q. de psychiatrische beroepsverenigingen een grote rol. Het lidmaatschap van de commissie uit 1961 van een verpleegkundige en van de commissie uit 1969 van twee verpleegkundigen laten 
evenwel zien dat de verpleegkundigen een aandeel krijgen in het inrichten van hun specialistische opleiding.

In 1971 krijgt de Katholieke Sociale Academie De Aemstelhoorn in Amsterdam toestemming om te beginnen met de opleiding tot sociaalpsychiatrisch verpleegkundige, die gaat heten: opleiding Maatschappelijke Gezondheidszorg afdeling Geestelijke Gezondheidzorg MGZ/GGZ. Het diploma ziekenverpleging A als toelatingseis vervalt in 1973. Het diploma ziekenverpleging B is daarmee voldoende. Twee jaar later wordt de opleiding in zeven plaatsen verspreid over het land aangeboden. In de tussentijd, in 1965, is de toelating van mannen tot de opleiding wijkverpleging geregeld. Mannen kunnen vanaf dan de opleiding B-nazorg volgen. Met het vervallen van de wijkaantekening als toelatingseis voor de nieuwe opleiding MGZ/GGZ neemt het aantal mannen in de extramurale psychiatrische verpleging verder toe. Naar schatting komt in 1995, op een totaal aantal verpleegkundigen van vijftien- tot zestienhonderd, de verhouding vrouwen-mannen op 47-53.

In de beginjaren van de nieuwe opleiding wordt er gezocht naar het "eigene" van de sociaalpsychiatrische verpleegkunde en bestaat er spanning tussen de opleiding en het werkveld. Het zoeken naar het eigene verloopt moeizaam. De klinische ervaring van de verpleegkundigen wordt als essentieel gezien voor de beroepsuitoefening, maar tegelijkertijd ook als een risico omdat ze teveel stigmatiserende elementen in zich heeft. De klinische ervaring onderscheidt de verpleegkundigen van de maatschappelijk werkenden en stelt hen in staat, zo wordt gezegd, "dingen anders te plaatsen". Een reden om de opleiding weer niet te zwaar als een verpleegkundige opleiding te accentueren is dat daarmee een te sterke koppeling wordt onderhouden met wat het medische model en het medisch-organische denken wordt genoemd. De trend in de psychiatrie is om daarvan los te komen. Die trend wordt zichtbaar in de invloed van bijvoorbeeld de agogiek en de andragogie op de opleiding. De verpleegkundige methodiek wordt daaraan ontleend omdat, zo wordt gesteld, de opleiding zich richt op begeleidend en helpend bezig zijn. In 1979 wordt de sociaalpsychiatrisch verpleegkundige omschreven als "een hulpverlener binnen de GGZ die een beïnvloedend proces probeert aan te gaan, gericht op de totale context van de hulpvrager, met name op de leefomgeving". In de opleiding staat de vereiste attitude-ontwikkeling voor de beroepsuitoefening in de maatschappelijke gezondheidszorg centraal. Wat die attitude inhoudt wordt niet nader omschreven.

De moeizame relatie tussen de opleidingen en het werkveld en met name de door de opleidingen nagestreefde autonomie is een terugkerend thema. Zo is het moeilijk om overeenstemming te bereiken over de eisen waaraan de stageplaatsen en de daar geboden begeleiding dienen te voldoen. De verschillende werkplekken hebben hun eigen ideeën over de eisen die aan de verpleegkundigen moeten worden gesteld en de opleidingen passen zich daaraan, ten minste voor een deel, aan. Dat er verschil van inzicht bestaat omtrent de eisen waaraan de verpleegkundigen moeten voldoen wordt in 1979 duidelijk. In het werkveld gaan stemmen op om de 
opleiding aan te passen, zodat de verpleegkundigen zich richten op de oorspronkelijke nazorgpatiënten. De opleidingen vinden dat aan die groep voldoende aandacht wordt besteed en voeren de gevraagde verandering niet door. Er zijn blijkbaar grenzen aan de aanpassingsbereidheid van de kant van de opleidingen.

Los van de beroepsopleiding tot sociaalpsychiatrisch verpleegkundige ontstaat rond 1970 bij de verpleegkundigen aandacht voor verdiepende bijscholing. Scholing op het gebied van bijvoorbeeld groepstherapie, relatietherapie en gedragstherapie maakt langzaamaan opgang. In 1976 verschijnt een door een verpleegkundige geschreven publicatie waarin wordt betoogd dat sociaalpsychiatrisch verpleegkundigen zich op gezinsbehandeling moeten gaan richten.

Van de registratie tot psychotherapeut, waarover in 1981 het advies van de commissie Verhagen wordt uitgebracht, worden de verpleegkundigen uitgesloten. Voor de registratie is een academische vooropleiding vereist.

Het ontstaan van de beroepsvereniging in 1979 kan worden gezien als een belangrijk moment in het proces van professionaliseren van de sociaalpsychiatrisch verpleegkundigen. De vereniging heeft aanvankelijk vooral ten doel invloed uit te oefenen op de arbeidsvoorwaarden van de verpleegkundigen. De aandacht komt al gauw ook te liggen op beroepsinhoudelijke zaken. Een voorbeeld is de discussie die wordt gevoerd over de ontwikkelingen binnen de beroepsgroep. Daaruit blijkt bezorgdheid omtrent de neiging van verpleegkundigen om de richting van therapeut op te willen gaan. De nazorg, en wat wordt genoemd de zorg voor kansarmen, wordt daardoor verwaarloosd. De opleidingen zouden zich, zo wordt gesteld, meer moeten gaan richten op curatieve werkzaamheden voor wat worden genoemd uitzichtloze gevallen.

\subsection{Sociale psychiatrie in de provincie Limburg tot omstreeks 1975}

Het domein van de sociale psychiatrie ontstaat in Limburg in de tweede helft van de jaren dertig, zo'n vijftien tot twintig jaar nadat de eerste initiatieven elders in het land zijn genomen. Aanvankelijk verlopen de ontwikkelingen traag. Het zijn kleine aantallen patiënten, met name kinderen en volwassenen zonder inrichtingsverleden die gebruik maken van de spreekuren. Die spreekuren worden verzorgd door psychiaters van de Venrayse inrichtingen Sint Servatius en Sint Anna, geassisteerd door een verpleegkundige. Incidenteel legt de verpleegkundige huisbezoeken af. Nazorg in de letterlijke zin van het woord is dan nog niet aan de orde.

Met de komst van de fulltime huisbezoekster in 1940 zet de groei in. De verpleegkundige legt grote aantallen huisbezoeken af. Ze richt zich daarbij met name op (ex-)inrichtingspatiënten en daarmee dus op nazorg. De groei zet na het einde van de oorlog door en komt voor het grootste deel voor rekening van de zich uitbreidende groep verpleegkundigen. Het aantal psychiaters blijft tot ver in de jaren zestig klein. Ze werken tot die tijd, op één uitzondering na, parttime. Omstreeks 
1960 werken er in Limburg zes nazorgverpleegkundigen. Naast het afleggen van de huisbezoeken nemen ze, samen met de psychiaters, deel aan maandelijkse besprekingen in de inrichtingen, waar wordt overlegd over proefverlof, ontslag of (her)opname van patiënten. Dat overleg is geen garantie voor goede afstemming. Het komt regelmatig voor dat ontslagen worden geregeld buiten de nazorgdienst om of dat opnames, noodzakelijk volgens die diensten, niet worden gerealiseerd.

Vanaf 1958 begint het aantal contacten tussen de inrichtingen en de nazorg toe te nemen. De grote stijging in contacten met de nazorg tot 100 procent in 1963 begint na de komst van de provinciale nazorgpsychiater in 1960. De contacten bestaan voor het overgrote deel uit brieven waarin proefverlof of ontslag worden aangekondigd. Tegelijkertijd neemt het aantal contacten tussen inrichtingspsychiaters en naasten van de patiënten af.

De positie van de inrichtingspsychiaters blijft belangrijk. De echte psychiatrie speelt zich af binnen de inrichtingen; sociale psychiatrie blijft lang een afgeleide van de inrichtingspsychiatrie. Sociale psychiatrie berust in hoge mate op ervaring en inzicht en is in wezen een vorm van maatschappelijke dienstverlening, gericht op het voorkomen van (her)opnames en het bespoedigen van ontslag.

Zonder de nazorgverpleegkundigen kan de sociale psychiatrie niet functioneren. Zij zijn het die de patiënten bezoeken en controleren en informatie verstrekken aan de psychiaters. De informatie van de verpleegkundigen speelt een doorslaggevende rol bij de besluitvorming rond proefverlof, ontslag en (her)opname.

In 1956 wordt een begin gemaakt met de regionalisering van de extramurale geestelijke gezondheidszorg, die in 1960 haar voorlopige beslag krijgt. Daarmee loopt Limburg in organisatorische zin vooruit op de Riagg-vorming die in 1982 landelijk wordt gerealiseerd. Het personeelsbestand blijft groeien. Alleen al in de regio Maastricht zijn in 1972 zes sociaalpsychiatrisch verpleegkundigen, twee psychiaters en twee psychologen in dienst.

Rond 1970 tekenen zich ook meer inhoudelijke veranderingen af. In de nazorgpopulatie groeit de groep die kan worden aangeduid als jonge chronici, een groep die intensieve begeleiding behoeft. Maar er komt ook een nieuw type patiënt in beeld, de groep met wat wordt genoemd psychosociale en levensproblemen. Daarmee verschuiven de werkzaamheden in het domein van de sociale psychiatrie van nazorg naar voorzorg. De komst van een nieuwe beroepsgroep, de psychologen, maakt een eind aan de hegemonie van psychiaters en verpleegkundigen en draagt bij aan de nieuwe, meer behandelingsgerichte oriëntatie van de sociale psychiatrie. De nazorg heeft daarmee, goed dertig jaar na haar ontstaan, in haar bekende vorm de langste tijd gehad.

De ontwikkelingen in de sociale psychiatrie in Limburg verlopen in grote lijnen niet veel anders dan de ontwikkelingen elders in het land, ofschoon ook daar de ontwikkelingen niet overal gelijk opgaan. Er zijn aanzienlijke verschillen tussen steden en 
provincies en ook verschillen tussen steden onderling en provincies onderling. Belangrijkste verschil is dat de ontwikkelingen in Limburg later beginnen en lange tijd langzamer verlopen. Voor dat gegeven kunnen enkele verklaringen worden aangevoerd.

Vooral in de snel groeiende steden is wat nu de grotestedenproblematiek wordt genoemd omvangrijk en duidelijk merkbaar. Het nemen van initiatieven op het gebied van de geestelijke hygiëne en de voor- en nazorg is daarmee urgent. Die urgentie is groter dan in Limburg, waar de problemen, gezien tegen de achtergrond van een meer homogene bevolkingsopbouw en de veelal op religieuze grondslag functionerende maatschappelijke verbanden, minder actueel zijn. De steden hebben, anders dan de kleine gemeentes in Limburg, een direct merkbaar financieel belang bij opnamepreventie en -verkorting van relatief omvangrijke groepen patiënten. Ze kunnen, omdat ze grote spelers zijn in het domein van de sociale psychiatrie, een vuist maken en de regie voeren, althans meer dan in Limburg waar het Groene Kruis die regiefunctie niet of in beduidend mindere mate heeft. De financiering van de voor- en nazorg vormt in Limburg, maar ook elders buiten de grote steden, lange tijd een belemmering voor de ontwikkeling van de sociale psychiatrie. Daarin komt voor een deel verandering met de rijkssubsidieregeling van 1961, en helemaal met de financiering van de sociale psychiatrie via de AWBZ in 1971.

De trage ontwikkeling van de sociale psychiatrie in Limburg kan ook worden verklaard door een voortdurend tekort aan psychiatrische mankracht. Die is deels het gevolg van de beperkte financiën, deels van de lage status die de sociale psychiatrie heeft en deels van het algemene tekort aan psychiaters, al dan niet met een katholieke achtergrond. In Sint Servatius komt in 1957 de eerste zenuwarts in dienst. Tot dan werken er enkel artsen met psychiatrische ervaring.

Ook de houding van de inrichtingen is een belangrijke verklaring voor de late start van de nazorg. De directie van Sint Anna ziet daarin geen leidende taak weggelegd en wil hoogstens meewerken door het beschikbaar stellen van een psychiater en een verpleegkundige ten behoeve van het consultatiebureau. Het kleine aantal verwijzingen van patiënten uit de inrichtingen naar de nazorgdiensten kan al evenzeer worden gezien als een uiting van weinig enthousiasme.

Bij de invloed van de Rooms Katholieke Kerk, die in die tijd in Limburg groot is, kan een vraag worden gesteld. De Limburgse geestelijkheid heeft zich in het bestuur van het Groene Kruis herhaaldelijk sterk gemaakt voor de geestelijke gezondheid in de provincie. Of er rechtstreekse invloed is van de kerk op de ontwikkeling van de sociale psychiatrie en zo ja, of die verband houdt met de relatief late start en de trage ontwikkeling ervan, is niet duidelijk.

De regionalisering van de extramurale psychiatrie die in Limburg al in 1960 haar beslag krijgt, kan bijzonder worden genoemd. In het betrekkelijk homogene Limburg, zijn geen dominante gemeentes en spelen twee katholieke inrichtingen en het katholieke Groene Kruis een invloedrijke rol. In deze institutionele leegte komt rela- 
tief makkelijk een moderne infrastructuur voor extramurale geestelijke gezondheidszorg tot stand. Die structuur houdt stand als het proces van secularisatie op gang komt en de rol van kerk en religie minder prominent wordt. Vanaf dan loopt de extramurale geestelijke gezondheidszorg in Limburg jarenlang vooruit op de ontwikkelingen elders in Nederland.

\subsection{De geestelijke gezondheidszorg vanaf omstreeks 1985 tot heden}

In de jaren na de Riagg-vorming in 1982 zet de groei van het domein van de geestelijke volksgezondheid onverminderd sterk door. Dat geldt zowel voor het intra- als voor het extramurale deel. In 1982 vragen 7 op de 1.000 inwoners om hulp. Dat aantal is in 1997 gestegen tot 17 per 1.000. De jaarprevalentie van het aantal cliënten in de hele Nederlandse geestelijke gezondheidszorg wordt in 1997 geschat op meer dan een miljoen. De Riagg's nemen daarvan het leeuwendeel voor hun rekening. Daar is in 2006 anderhalf procent van de bevolking, ongeveer 247.500 personen, ingeschreven. Met het patiëntenbestand groeit de personeelsomvang. In 1989 zijn er rond de 35.000 volledige arbeidsplaatsen. Dat aantal komt in 1996 op omstreeks 45.400 en blijft in de jaren daarna toenemen.

Maar het is niet enkel groei die de geestelijke gezondheidszorg kenmerkt. Ook inhoudelijk voltrekken zich belangrijke ontwikkelingen.

In de Riagg's neemt de psychotherapie een steeds belangrijker plaats in. De psychotherapeuten, waaronder ook psychiaters die zich als zodanig hebben geschoold en actief zijn, worden daarmee de toonaangevende beroepsgroep. Ook in de psychiatrische ziekenhuizen en de psychiatrische afdelingen van de algemene ziekenhuizen wint de psychotherapie terrein, zij het minder dan in de Riagg's.

In de inrichtingen zet de ingezette trend zich voort om de opnames zo kort mogelijk te houden. Mede als gevolg daarvan stijgt het aantal ontslagen sterk en daarmee de vraag naar nazorg. De Riagg's kunnen deze vraag niet aan, als gevolg waarvan de inrichtingen daaraan zelf door uitbreiding van poliklinieken aandacht gaan besteden. Desondanks ontstaat er een groeiende groep patiënten voor wie onvoldoende continuïteit in de zorgverlening wordt gerealiseerd.

De zich uitbreidende poliklinieken ontwikkelen zich in korte tijd tot afdelingen voor brede extramurale hulpverlening en gaan daarmee steeds meer lijken op de afdelingen voor volwassenenzorg van de Riagg's.

In de loop van de jaren tachtig begint de biologisch georiënteerde psychiatrie, die een tijd lang uit de gratie, maar niet helemaal verdwenen is geweest, aan een heropkomst. Ze krijgt daarbij de wind in de zeilen door het beschikbaar komen van effectieve psychofarmaca. Dat draagt ertoe bij dat zowel bij voorschrijvers als bij de gebruikers, naast psychotherapie, geneesmiddelen weer een acceptabele behandelvorm worden. 
Voor de psychiaters heeft de toenemende medisch-biologische oriëntatie een versteviging van de positie tot gevolg. Ze zijn nu actief op het terrein van zowel de psychiatrische diagnostiek als van de psychotherapeutische en de medicamenteuze behandeling en bestrijken daarmee het hele therapeutische werkveld. Ze krijgen weer een aansturende rol in de positie van behandelcoördinator of teamleider. Dat geldt vooral voor de Riagg's. In de intramurale sector is de positie van de psychiaters minder in het geding geweest.

De psychotherapie begint in de loop van de jaren negentig duidelijk van karakter te veranderen. Veel toegepaste vormen van fundamentele en inzichtgevende behandeling worden vervangen door meer pragmatische, probleemgeoriënteerde werkwijzen. Die omslag kan op twee manieren worden verklaard. De eerste is dat die psychotherapie "oude stijl" te eenzijdig ten goede komt aan relatief jonge, goed opgeleide en gemotiveerde hulpvragers. De groep die niet aan deze kenmerken voldoet is daardoor onderbedeeld, zo luidt de kritiek die al vanaf het ontstaan van de Riagg's wordt geuit. Belangrijk is echter ook het groeiende inzicht dat de meer persoonsgerichte vormen van psychotherapie onvoldoende effectief zijn voor beide groepen patiënten en dat rationele werkwijzen zoals cognitieve therapie meer effect sorteren. Evidence based werken wordt ook in de geestelijke gezondheidszorg richtinggevend uitgangspunt. De psychotherapie oude stijl heeft daarmee als prominente behandelvorm haar langste tijd gehad. Veel psychotherapeuten beginnen een eigen praktijk. Hun plaats wordt ingenomen door psychiaters, psychologen-niet psychotherapeut en sociaalpsychiatrisch verpleegkundigen.

De overheid krijgt in de loop van de jaren in toenemende mate invloed op de geestelijke gezondheidszorg. Al vanaf de jaren zeventig is die invloed herkenbaar in de vorm van bijvoorbeeld de Structuurnota Geestelijke Gezondheidszorg uit 1974 en de Nieuwe Nota Geestelijke Gezondheidszorg uit 1984.

Centraal thema in de overheidsbemoeienis is het tot stand brengen van een geintegreerd, alomvattend en bereikbaar, dus geregionaliseerd maar ook beheersbaar systeem van voorzieningen. Continuïteit van zorg is daarbij een belangrijk uitgangspunt. Een en ander wordt nader uitgewerkt in onder meer de Beleidsvisie Geestelijke Gezondheidszorg van 1999. Daarin wordt versterking van de eerstelijn aangekondigd, beëindiging van de Riagg's en de psychiatrische ziekenhuizen als aparte voorzieningen en een herziening van de beroepenstructuur. Er wordt ingezet op zaken als opnamepreventie en -vervanging, het opzetten van zorgketens om de continuïteit van zorg te verbeteren, vraagsturing in plaats van aanbodsturing en versterking van de positie van de cliënten.

Dat laatste wordt onder meer zichtbaar in het tot stand komen van de Wet Bijzondere Opnemingen Psychiatrische Ziekenhuizen BOPZ in 1992 en de Wet op de Geneeskundige Behandelovereenkomst WGBO in 1995. Maar ook los van wetgeving groeit de rol van de cliënten of hun vertegenwoordigers. Dat wordt onder meer 
duidelijk door invloed die de vereniging voor familieleden en betrokkenen van mensen met schizofrenie of een psychose "Ypsilon" heeft. Als laatste voorbeeld van de veranderende rol van de cliënten kan worden genoemd het betrekken van ervaringsdeskundigen bij het geven van voorlichting en bij het opstellen van zorgprogramma's en behandelrichtlijnen.

De bemoeienis van de overheid leidt er mede toe dat de organisatorische samenwerking tussen psychiatrische inrichtingen en Riagg's steeds duidelijker contouren krijgt. Het vanaf begin jaren negentig in gang gezette fusieproces tussen intraen extramurale instellingen gaat onverminderd voort en zo'n tien jaar later, in 2003, wordt de ontmanteling van die omvangrijke instellingen aangekondigd. De geestelijke gezondheidszorg zal voortaan bestaan uit twee lagen. In de eerste laag, de geintegreerde eerstelijnszorg, wordt voor het grootste deel van de mensen met psychische stoornissen kortdurende generalistische hulp verleend door huisarts, maatschappelijk werkende of eerstelijnspsycholoog. De tweede laag, de gespecialiseerde ambulante en klinische geestelijke gezondheidszorg, is er voor mensen met ernstige en complexe problemen die in de eerstelijn niet behandeld kunnen worden. Voor een deel zijn dat de naar schatting 60.000 personen die langdurige zorg en begeleiding nodig hebben, waarvan zo'n 25.000 intensief, onder meer als gevolg van sociale en gedragsproblemen. Doel is niet genezing of herstel, maar het leren omgaan met de beperkingen als gevolg van de stoornis.

Het overheidsbeleid is, zoals ook in de somatische gezondheidzorg, gericht op wat de minister noemt het behandelen van ziekten en het zoveel mogelijk beperkt houden van de schadelijke effecten daarvan. Ter bevordering van de zorginhoudelijke samenhang en van de doelmatigheid van de gehele curatieve zorg wordt de financiering van wat in termen van de minister wordt aangeduid als de geneeskundige geestelijke gezondheidszorg per 1 januari 2008 overgeheveld van de AWBZ naar de Zorgverzekeringswet. Als verrekeningsmodel wordt in die geneeskundige geestelijke gezondheidszorg, net zoals in de somatische gezondheidszorg, de systematiek van de diagnose-behandelcombinaties ingevoerd.

Psychiatrische problemen worden in het vervolg op één lijn gesteld met somatische problemen en als medisch in de letterlijke betekenis van het woord gekarakteriseerd.

\subsection{De sociaalpsychiatrische verpleegkunde vanaf de Riagg-vorming}

Met de groei van het sociaalpsychiatrische domein groeit door de jaren heen ook het aantal sociaalpsychiatrisch verpleegkundigen. In 1986 zijn er 761 formatieplaatsen, in 1995 zijn dat er 1.065. Van de naar schatting 1.544 actieve sociaalpsychiatrisch verpleegkundigen in de tweede helft van de jaren negentig is 87 procent werkzaam bij de Riagg's, de rest bij psychiatrische ziekenhuizen, consultatiebureaus voor alcohol en drugs en psychiatrische afdelingen van algemene ziekenhuizen. In 
2008 zijn er in Nederland maar schatting 2.850 sociaalpsychiatrisch verpleegkundigen. De groei van de beroepsgroep is slechts één aspect in de ontwikkeling ervan. Die ontwikkeling wordt sterk beïnvloed door ontwikkelingen in de extramurale geestelijke gezondheidszorg en door ontwikkelingen daaromheen.

De na de Riagg-vorming toenemende nadruk op psychotherapie, uitgevoerd ten behoeve van de groeiende groep patiënten met psychosociale en levensproblemen, leidt ertoe dat verpleegkundigen zich psychotherapeutisch gaan oriënteren, in elk geval psychotherapeutische inzichten en werkwijzen overnemen. Ze richten zich steeds meer, maar niet allemaal en niet exclusief, op voornoemde patiëntencategorie. Daarmee raakt de aandacht voor de oorspronkelijke groep, de al dan niet chronische patiënten met een inrichtingsverleden, later uitgebreid met een groep weinig redzamen, al dan niet in combinatie met gedragsproblemen, op de achtergrond. Het is ook niet langer de patiënt in diens leefomgeving die het centrale aandachtspunt van de verpleegkundigen vormt, maar de patiënt die het Riagg bezoekt. Halverwege de jaren negentig heeft ongeveer 60 procent van de contacten van de verpleegkundigen plaats binnen de muren van het Riagg. 60 Procent van de verpleegkundigen heeft contact met de cliënt zelf, negentien procent met diens partner en tien procent met het gezin. Zes procent van de verpleegkundigen werkt met cliëntgroepen.

Zowel cliënten als hun problemen zijn divers. Het gaat om mensen met psychiatrische problemen en stoornissen in engere zin, maar vooral om mensen met bijvoorbeeld een beperkt sociaal netwerk, arbeids- huisvestings- en financiële problemen, relatie- en zingevingsvragen, problemen als gevolg van mishandeling en geweld, problemen met het verbaliseren en een relatief laag opleidingsniveau. Chronische patiënten vormen met naar schatting vijftien procent de minderheid van de clientèle van de verpleegkundigen. Vergeleken met andere Riagg-werkers richten de verpleegkundigen zich niet zozeer op de behandeling van mensen met manifeste psychiatrische problemen, maar vooral op de groep die er sociaal en maatschappelijk slecht voor staat. De kerntaken van de verpleegkundigen bestaan voor het grootste deel uit het voeren van intakegesprekken, het houden van spreekuren en baliediensten, het doen van crisisinterventie en het voeren van behandel- en begeleidingsgesprekken. Concreet komt de directe patiëntenzorg vooral neer op het bieden van steun en structuur en het adviseren bij materiële en immateriële problemen. Daarna komen zaken als netwerkontwikkeling- en ondersteuning, zorgcoördinatie en activiteiten rond het beheer en gebruik van medicijnen.

Tot begin jaren negentig zijn de sociaalpsychiatrisch verpleegkundigen de enige verpleegkundigen die een rol van betekenis spelen op het domein van de sociale psychiatrie. Dat verandert als vanaf die tijd de psychiatrisch intensieve thuiszorg ontstaat. Vanuit de psychiatrische inrichtingen bieden inrichtingsverpleegkundigen kortdurende zorg, gericht op onder meer ADL-functies, medicatiegebruik en het geven van omgangsadviezen aan naasten van patiënten, met als doel het verkorten of voorkomen van (her)opnames. 
Omstreeks 2000 worden ook andere verpleegkundigen, zoals die met de opleiding Verpleegkundig Specialist GGZ of met masteropleiding Advanced Nursing Practice of Evidence Based Practice, actief op het domein van de sociale psychiatrie. In 2002 wordt de beroepsopleiding tot sociaalpsychiatrisch verpleegkundige, de opleiding MGZ/GGZ, opgeheven. Nog voordat in 2007 de laatste diploma's worden uitgereikt, gaat op initiatief van de Nederlandse Vereniging van Sociaal Psychiatrisch Verpleegkundigen, in samenwerking met enkele hogescholen, de opleiding Post HBOSPV van start. Het is deze opleiding die door de NVSPV-V\&VN wordt gezien als de nieuwe beroepsopleiding. Gediplomeerden van de overige nieuwe opleidingen worden enkel onder voorwaarden ingeschreven in het in 2003 door de beroepsvereniging ingestelde SPV-register. Met de opleiding Post HBO-SPV wordt beoogd beroepsbeoefenaren op te leiden die gaan werken voor wat wordt omschreven als de groep mensen die buiten de boot dreigt te vallen, in een (dreigend) sociaal isolement verkeert en op vele fronten kwetsbaar is.

Het formuleren van deze opleidingsdoelen sluit aan bij een ontwikkeling binnen de beroepsgroep die vanaf het begin van de jaren negentig herkenbaar wordt uitgedragen en die kan worden samengevat als de aandacht voor het sociaalpsychiatrische gedachtegoed. Er wordt onder meer voor gepleit om de patiënt te zien als onderdeel van zijn maatschappelijke en sociaal-culturele context, om die context te betrekken in de behandeling en om behoefte- in plaats van diagnosegeoriënteerd te werken. Sociale psychiatrie wordt geplaatst tegenover wat wordt genoemd de resultaatgerichte en instrumenteel-technische zorg en is, zo wordt gesteld, meer dan enkel extramurale psychiatrie.

Toch is het niet alleen de zorg voor de kansarmen en kwetsbaren waarop de sociaalpsychiatrisch verpleegkundigen inzetten. Ze zijn vanaf het begin van dit decennium actief in de eerstelijns gezondheidszorg. Werkers uit de Riagg's worden ingezet om door middel van consultatie de eerstelijn te versterken. De verpleegkundigen nemen een aanzienlijk deel van die consultatie voor hun rekening. In 2004 gaat het om afgerond 76 procent van het totale aantal van bijna 10.000 .

De ondersteuning van de eerstelijn is in $\mathbf{2 0 0 1}$ geformaliseerd met het instellen van zogenoemde Regionale Ondersteunings Structuren. Als vervolg daarop is in 2008 de functie van Praktijkondersteuner Huisarts-GGZ ingesteld. Als kandidaten voor het vervullen van de nieuwe functie worden genoemd sociaalpsychiatrisch verpleegkundigen en maatschappelijk werkenden. De beroepsverenigingen van beide in aanmerking komende beroepsgroepen hebben inmiddels een functieprofiel Praktijk Ondersteuner Huisartsenzorg POH-GGZ opgesteld. De NVSPV/V\&VN geeft met de deelname aan het ontwikkelen van het profiel te kennen serieus in te willen zetten op de uitbreiding en consolidering van de rol van sociaalpsychiatrisch verpleegkundigen in de eerstelijn. Vooralsnog is onduidelijk of en hoe deze domeinuitbreiding zich verder zal ontwikkelen. 
Zo heerst er ook nog onduidelijkheid omtrent de gevolgen van de voorgenomen decategorisering van de tweedelijns geestelijke gezondheidszorg. Sociaalpsychiatrisch verpleegkundigen kunnen, zoals het er uitziet, worden ingezet in de gespecialiseerde geestelijke gezondheidszorg bij een deel van de naar schatting 60.000 patienten met complexe problemen. Het rapport "Zorg van velen" waarin de minister wordt geadviseerd te komen tot gecontextualiseerde zorg is wat dat aangaat op maat gesneden. Of dat gaat gebeuren, en zo ja, of die zorg gaat worden ingericht zoals de verpleegkundigen bepleiten, is de vraag. Het is niet uitgesloten dat ook hier dat wat de verpleegkundigen instrumentalisering en protocollering noemen, aan de orde zal zijn. Daarop zetten ze, in elk geval vooralsnog, niet in.

Het is denkbaar dat extramuraal geestelijkegezondheidszorgverpleegkundigen actief zullen zijn binnen drie subdomeinen van de extramurale geestelijke gezondheidszorg: de generalistische eerstelijn en de twee onderdelen van de specialistische tweedelijn, te weten het deel daarvan dat zich richt op behandeling en het andere deel dat zich richt op zorg en begeleiding. Van die groep verpleegkundigen zullen zij die zich tot nu toe sociaalpsychiatrisch verpleegkundigen noemen, in afnemende mate deel uitmaken. De titel sociaalpsychiatrisch verpleegkundigen bestaat formeel al niet meer en het is de vraag of de anders opgeleide verpleegkundigen het bijvoeglijk naamwoord sociaalpsychiatrisch zullen gebruiken. Of daarmee het sociaalpsychiatrisch gedachtegoed uit beeld zal geraken, is moeilijk te zeggen.

\subsection{Terugkoppeling naar de theorie}

In onderstaand schema zijn de belangrijkste ontwikkelingen in het domein van de sociale psychiatrie en in de belangrijke beroepsgroepen die in dat domein actief zijn, weergegeven. Ze worden aan de hand van het schema geformuleerd in termen van Abbott's professionaliseringsideeën en geconcretiseerd in termen van de van Benson afgeleide ideeën omtrent intra- en interprofessionele coherentie. Aangetekend kan worden dat de vraag hoe de verpleegkundigen in de praktijk van alledag concreet hun claim waarmaken niet eenvoudig is te beantwoorden. Hetzelfde kan worden opgemerkt met betrekking tot de psychiaters. Als verklaring kan worden gegeven dat het werk van beide beroepsgroepen, in tegenstelling tot sommige andere professies, niet goed kan worden omschreven in termen van technische activiteiten en daarbij passende, min of meer afgebakende, volgtijdelijke handelingen.

De claim van de sociale psychiatrie is tot begin jaren zestig een eenvoudige: het buiten de inrichting houden van mensen met psychiatrische problemen. Aanvankelijk gebeurt dat door het verlenen van nazorg. Later, te beginnen in de jaren vijftig, komt daar voorzorg bij. Inhoudelijk verschillen voor- en nazorg niet veel van elkaar. Het gaat om een beperkt scala aan activiteiten waarin controle en structuur voorop staan. Middelen om dat te realiseren zijn vooral de grote aantallen huisbezoeken 


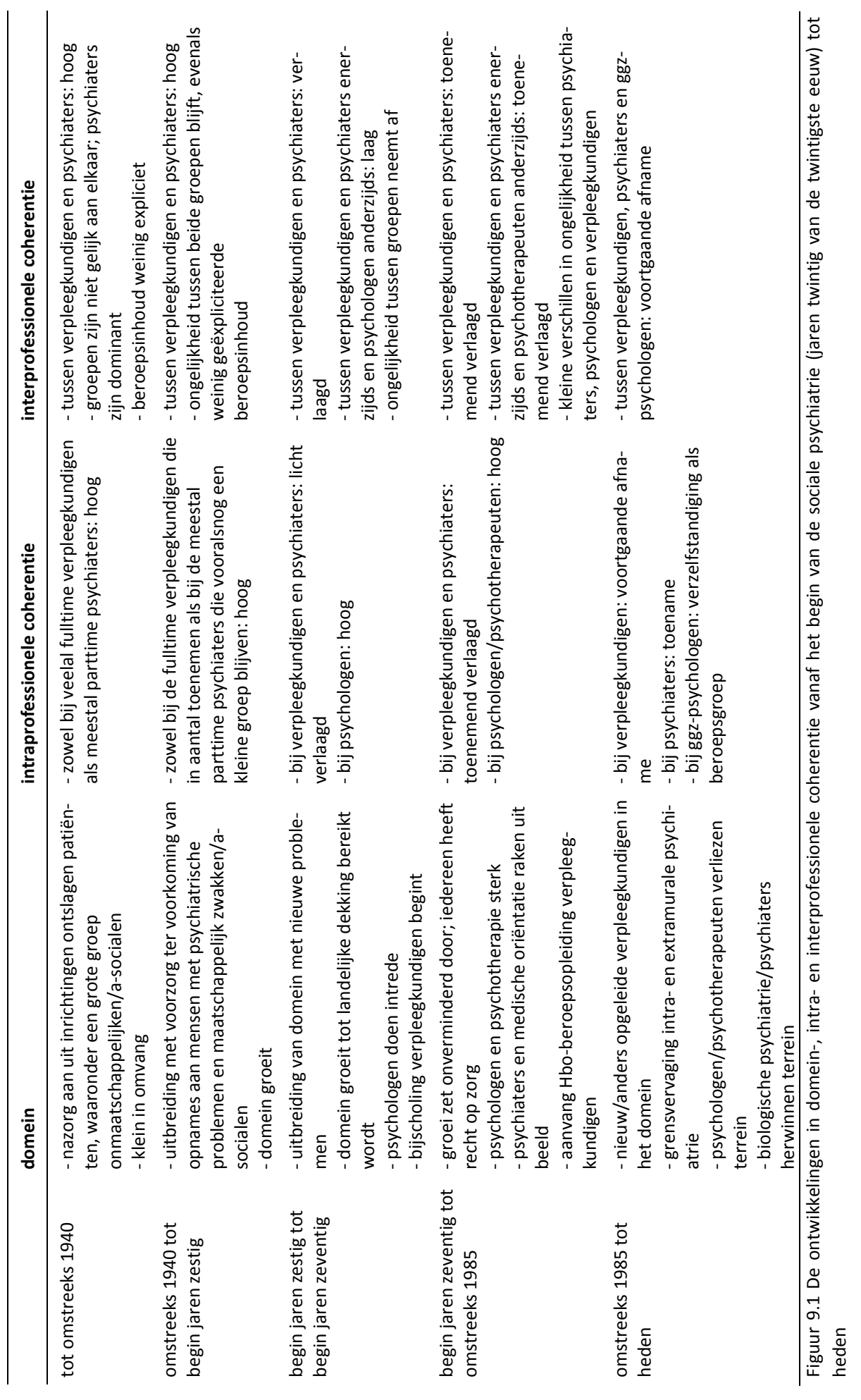


die voor rekening komen van de verpleegkundigen en de spreekuren die worden gedaan door de psychiaters.

De claim van de sociale psychiatrie wordt gerealiseerd door de twee beroepsgroepen die binnen het domein actief zijn. Zij zijn de enige professionele spelers in het domein. De domeinclaim is dezelfde als die van de twee beroepsgroepen. Ze werken nauw samen en de verhoudingen zijn duidelijk. De kleine aantallen psychiaters, veelal parttime werkend, zijn de baas en eindverantwoordelijk, de grotere aantallen veelal fulltime werkende verpleegkundigen voeren binnen de grenzen die de psychiaters stellen, de activiteiten uit. Die grenzen zijn hoe dan ook ruim en de verpleegkundigen kunnen in hoge mate zelf bepalen hoe ze hun werkzaamheden concreet invullen. Eigen inzicht en ervaring zijn belangrijk en dat geldt zowel voor de verpleegkundigen als voor de psychiaters. Er bestaat nog niet zoiets als een kennisgebied sociale psychiatrie of sociaalpsychiatrische verpleegkunde. Dat de verpleegkundigen vanaf 1937 een beroepsopleiding, de B-nazorg kunnen volgen, doet daar niets aan af.

De claim is een succesvolle. Het blijkt mogelijk om patiënten zonder al te veel problemen buiten de inrichting te laten verblijven. Aantallen patiënten nemen langzaam maar gestaag toe. Het belang dat daaraan wordt toegekend wordt onderstreept door de gedeeltelijke financiering via de Rijkssubsidieregeling in 1961.

De financiering en de daaraan verbonden personeelsmatige eisen kunnen echter ook worden gezien als een uiting van overheidsbemoeienis. De overheid verbindt voorwaarden aan de financiering en stuurt daarmee, zij het nog niet zozeer op inhoud, dan toch op inrichting en organisatie van de Sociaal Psychiatrische Diensten. Er dient zich dus een nieuwe speler aan in het domein van de sociale psychiatrie wiens invloed vanaf de jaren zeventig steeds duidelijker merkbaar gaat worden. De diensten kunnen dankzij de financiering groeien en gaan zich steeds meer richten op cliënten zonder ernstige of acute psychiatrische beelden, die gebaat zijn bij langdurige begeleiding en ondersteuning.

Voor de werkzaamheden van zowel psychiaters als verpleegkundigen heeft de uitbreiding met deze groep geen noemenswaardige gevolgen. De claim verandert er ook nog niet door. Datzelfde geldt voor de intra- en interprofessionele coherentie. Zowel binnen als tussen de twee groepen is de coherentie hoog. Er bestaat overeenstemming in de opvatting dat nazorg ten behoeve van inrichtingspatiënten de kern is van beider activiteiten. Als in de loop van de jaren vijftig een nieuwe patiëntcategorie in beeld komt, te weten de groep die nog niet eerder in een inrichting opgenomen is geweest, wordt voorzorg, het voorkomen van opnames, een nieuwe functie van de sociale psychiatrie die door beide beroepsgroepen wordt onderschreven. Dat is een aanwijzing voor zowel intra- als interprofessionele ideologische consensus. De ideologie is nog weinig ontwikkeld en gedifferentieerd. In meer hedendaagse termen gaat het om care, begeleiding en ondersteuning. 
Binnen en tussen de beroepsgroepen bestaat eveneens overeenstemming over de rol en de taken die er moeten worden vervuld. Dat is een aanwijzing voor zowel intra- als interprofessionele domeinconsensus. Het gegeven dat er binnen en tussen de beide beroepsgroepen in de praktijk van alledag blijkbaar zonder problemen met elkaar wordt samengewerkt, is een aanwijzing voor positieve evaluatie van elkaars werkzaamheden en voor werkcoördinatie. Vooralsnog is dat alles weinig doordacht en uitgewerkt. Duidelijk is de hiërarchie tussen de meestal parttime werkende psychiaters en de veelal fulltime werkende verpleegkundigen. Die wordt onderstreept door het feit dat het de psychiaters zijn die het voortouw nemen voor de nazorgopleiding van de verpleegkundigen en daar lange tijd de inhoud van bepalen. In het dagelijkse werk hebben de verpleegkundigen, binnen de grenzen die de hiërarchie stelt, veel ruimte om hun werk naar eigen inzicht te organiseren en uit te voeren.

Beide beroepsgroepen op het domein van de sociale psychiatrie in Nederland zijn gedurende de eerste drie tot vier decennia van het bestaan van dat domein, in termen van zowel intra- als interprofessionele coherentie in evenwicht.

Veranderingen beginnen zich af te tekenen aan het begin van de jaren zestig. Het domein krijgt een impuls tot uitbreiding met de landelijke subsidieregeling voor Sociaal Psychiatrische Diensten. Vanaf die tijd komt de naam sociaalpsychiatrisch verpleegkundige steeds meer in gebruik. Belangrijk zijn de komst van de psychologen die een merkbare rol gaan spelen in het domein van de sociale psychiatrie en de beweging van de antipsychiatrie die aan betekenis wint. De invloed van sociaalmaatschappelijke en interpersoonlijke factoren op ontstaan en oplossen van psychiatrische, psycho-sociale en levensproblemen krijgt sterke nadruk.

Met de aandacht daarvoor verandert de claim van de sociale psychiatrie en treedt er differentiatie op in de claim. Niet enkel meer het buiten de inrichting houden van patiënten, maar ook preventie, het behandelen en oplossen van problemen, is aandachtspunt. Daarbij passen nieuwe benaderingen en in betrekkelijk korte tijd winnen psychotherapeutische behandelmethoden terrein. Voor- en nazorg oude stijl, met als functies controle, begeleiding en ondersteuning, raken op de achtergrond, maar verdwijnen niet.

De wijzigingen in de domeinclaim voltrekken zich ook in de claim van psychiaters en verpleegkundigen. Dat gebeurt vooralsnog langzaam en niet in beide beroepsgroepen als geheel. De opkomende interesse voor psychotherapeutisch georienteerde werkwijzen en voor scholing op dat gebied bij sommige, lang niet alle verpleegkundigen is daarvan een voorbeeld.

De tot dan toe hoge intra- en interprofessionele coherentie in en tussen beide beroepsgroepen is niet langer meer vanzelfsprekend en is licht verlaagd vergeleken met de jaren ervoor. De coherentie tussen verpleegkundigen en psychiaters enerzijds en psychologen anderzijds kan laag worden genoemd. 
Vanaf begin jaren zeventig worden duidelijker veranderingen merkbaar. De AWBZfinanciering van de sociale psychiatrie vanaf 1971 geeft de sector een zeer belangrijke impuls. Deze vorm van financiering kan worden gezien als een maatschappelijke erkenning van het succes van de claim van de sociale psychiatrie, in elk geval als het onderschrijven van het belang ervan. De financiering heeft tot gevolg dat de sector kan blijven groeien.

Tegen de achtergrond van veranderende opvattingen over ontstaan en behandeling van psychiatrische problemen, in combinatie met de instroom van een nieuwe categorie patiënten, bestaande uit mensen met wat wordt genoemd psychosociale en levensproblemen, begint de claim van de sociale psychiatrie merkbaar te veranderen. Het aandachtspunt verschuift van generieke begeleiding in de vorm van voor- en nazorg, gericht op het buiten de inrichting laten verblijven van psychiatrische patiënten, naar de extramurale, meer psychotherapeutisch georiënteerde behandeling van psychiatrische patiënten en van mensen met psychosociale en levensproblemen.

De verpleegkundigen, ofschoon niet de hele groep, gaan mee in deze nieuwe oriëntatie; de claim van de beroepsgroep wordt gedifferentieerder van aard. Een deel gaat zich richten op de nieuwe patiëntengroep en begint zich (psycho)therapeutisch bij te scholen en te specialiseren, een ander deel gaat op de oude voet verder. Er ontstaat binnen de beroepsgroep een zekere mate van divergentie in de overeenstemming omtrent werkterrein, de taken die daarop moeten worden verricht en kennis en vaardigheden die daarvoor nodig zijn. Datzelfde geldt voor de psychiaters.

De bemoeienissen van de psychiaters om de verpleegkundige opleiding te veranderen illustreren het bestaan binnen die eerste beroepsgroep, althans een deel ervan, van nieuwe ideeën omtrent de gewenste invulling van zowel de sociaalpsychiatrisch medische als de sociaalpsychiatrisch verpleegkundige praktijk. De bemoeienissen van de psychiaters met de verpleegkundige opleiding laten ook zien dat er nog steeds een bepaalde mate van hiërarchie bestaat tussen de beide beroepsgroepen. Dat neemt niet weg dat de verpleegkundigen, nog steeds, een hoge mate van autonomie hebben waar het gaat om het inrichten van hun werkzaamheden.

In het domein van de sociale psychiatrie kan zowel binnen de groep psychiaters en de groep verpleegkundigen als tussen beide groepen een afnemende maar nog redelijke mate van professionele coherentie worden waargenomen. Tussen die twee groepen enerzijds en de opkomende beroepsgroep van de psychologen anderzijds is de coherentie laag. De intraprofessionele coherentie binnen de groeiende groep psychologen is hoog.

$\mathrm{Na}$ de komst van de Riagg's zet de groei van het domein onverminderd door. De claim van wat nu minder vaak sociale psychiatrie maar steeds meer extramurale psychiatrie wordt genoemd, verandert snel. Preventie en extramurale behandeling 
van psychiatrische, psychosociale en levensproblemen zijn de aandachtspunten. De prominente manier van werken is psychotherapie en dan met name langerdurende, inzichtgevende vormen van psychotherapie. Met de steeds grotere rol van de psychotherapie en van psychotherapeutisch georiënteerde werkwijzen wordt de Riaggspreekkamer de werkplek. Het kenmerk bij uitstek van de sociale psychiatrie, het interveniëren in, rekening houdend met en gebruik makend van de directe omgeving van de patiënt, raakt, op crisisinterventie na, sterk op de achtergrond. Dat gaat door als in de loop van de jaren de biologische psychiatrie snel terrein wint en de langerdurende vormen van psychotherapie worden vervangen door meer pragmatische, probleemoplossende methodieken. De claim van de psychiaters neemt in kracht toe en gelijk opgaand daarmee de intraprofessionele coherentie binnen deze groep. De claim van de psychologen/psychotherapeuten neemt even snel in belang af. Zij verlaten in grote aantallen de Riagg's. Een nieuwe generatie vindt als GGZpsycholoog werk in de eerstelijn.

Binnen de verpleegkundige beroepsgroep is geen eenduidigheid in de claim die wordt gelegd. Er bestaat voortgaande divergentie in opvattingen. In de eerste plaats is dat de groep patiënten waarop de aandacht zich zou moeten richten: de groep kansarme, al dan niet chronische patiënten tegenover de groep met relatief lichte psychiatrische en psychosociale problemen. Vervolgens zijn er de activiteiten die ten behoeve van de patiënten zouden moeten worden verricht: begeleiding en ondersteuning versus behandeling/psychotherapie. Tot slot bestaat er divergentie in de visie van waaruit de werkzaamheden moeten worden verricht: de noodzaak tot het betrekken van de sociale context bij de benadering van de patiënt tegenover een geïndividualiseerde aanpak. Anders gezegd: domein- en ideologische consensus staan voortgaand onder druk. Datzelfde kan worden gezegd van positieve evaluatie van elkaars werkzaamheden en dus, samenvattend, van de intraprofessionele coherentie.

Anno 2008 kan de groep sociaalpsychiatrisch verpleegkundigen, werkzaam in het domein van de extramurale geestelijke gezondheidszorg, waar het gaat om domein- en ideologische oriëntatie in drieën worden onderverdeeld. Dit is een analytisch onderscheid: in concreto zijn dezelfde verpleegkundigen in verschillende settings werkzaam. De eerste groep zet in op het werken met al dan niet chronische patiënten met complexe problemen. De groep kiest voor wat wel de rehabilitatiebenadering wordt genoemd. Doel daarvan is niet zozeer genezing maar het op een zo volwaardig en humaan mogelijke manier invulling kunnen geven aan het leven, rekening houdend met en gebruik makend van de sociale context. De tweede groep richt zich op het "reguliere" Riagg-werk. Dat kan het best worden omschreven als laag tot matig complexe begeleiding van mensen met matig ernstige psychiatrische en psychosociale problemen. De derde groep is recent actief in de consultatieve sfeer in de eerstelijnszorg en zet in op bestendiging daarvan. De activiteiten daar zijn diagnostisch en consultatief van aard. Complicerende factor is dat de extramu- 
rale geestelijke gezondheidszorg niet langer het exclusieve werkterrein is van sociaalpsychiatrisch verpleegkundigen, maar dat er inmiddels anders opgeleide verpleegkundigen werkzaam zijn.

De claim van de verpleegkundigen is meer divers dan ooit tevoren. In het verlengde daarvan kan de conclusie luiden dat er binnen de beroepsgroep van de sociaalpsychiatrisch verpleegkundigen minder domein- en ideologische consensus bestaat dan voorheen. Tegen de achtergrond van de veronderstelde samenhang tussen deze twee dimensies en de dimensies positieve evaluatie van elkaars werkzaamheden en werkcoördinatie kan worden geconcludeerd dat deze twee laatsten niet hoog zullen zijn. Deze conclusie geldt bijgevolg voor het niveau van intraprofessionele coherentie binnen de verpleegkundige beroepsgroep.

\subsection{Methodologische en inhoudelijke kanttekeningen}

Bij deze studie kunnen enkele methodologische opmerkingen worden geplaatst, betrekking hebbende op betrouwbaarheid en validiteit. ${ }^{486}$ Met betrouwbaarheid wordt bedoeld de afwezigheid van toevallige vertekeningen, met validiteit wordt bedoeld de afwezigheid van systematische vertekeningen.

Een belangrijke indicator voor betrouwbaarheid is, al dan niet virtuele, herhaalbaarheid. Deze studie is in principe en met dezelfde methoden herhaalbaar omdat de onderzochte situatie niet is veranderd. De enige reserve geldt voor de interviews. Mogelijk zijn niet alle verpleegkundigen, waarvan de informatie uit hoofdstuk 7 afkomstig is, gezien hun hoge leeftijd nog bereikbaar. Een ander aspect van betrouwbaarheid is intersubjectieve overeenstemming tussen leden van het onderzoeksteam. Deze overeenstemming is in deze studie op verschillende manieren gewaarborgd. Zo is in de loop van het project de stand van zaken regelmatig besproken tussen de onderzoeker en de onderzoeksbegeleiders. Dat wordt ook wel aangeduid met argumentatieve betrouwbaarheid. Bij de voorbereiding en de uitvoering van het in hoofdstuk 6 beschreven statusonderzoek is interbeoordelaarsovereenstemming gewaarborgd. Tussen de in dit geval twee onderzoekers en de onderzoeksbegeleiders is met enige regelmaat gecontroleerd op overeenstemming in de gezochte informatie en de interpretatie daarvan.

In deze studie is gebruik gemaakt van literatuur, archieven, patiëntstatussen en van interviews. Deze vorm van bronnentriangulatie wordt geacht bij te dragen aan de validiteit. Het bereiken daarvan wordt onderstreept door het optreden van datasaturatie, zowel binnen als tussen de verschillende typen bronnen.

Het kan opvallend worden genoemd dat weinig informatie is verkregen over de groep maatschappelijk werkenden. Dat is opvallend omdat het een beroepsgroep is

\footnotetext{
${ }^{486}$ Voor begripsdefinities en concrete uitwerkingen wordt verwezen naar Maso, I., \& Smaling, A. (1998). Kwalitatief onderzoek: praktijk en theorie. Amsterdam: Boom, hoofdstuk 4, 64-86.
} 
die nogal eens wordt geassocieerd met de groep sociaalpsychiatrisch verpleegkundigen. Het is aannemelijk dat de verpleegkundigen en de maatschappelijk werkenden aanvankelijk door een getalsmatige oorzaak niet zoveel met elkaar in aanraking zijn gekomen. Het aantal maatschappelijk werkenden in de extramurale psychiatrie bedraagt in 1975 naar schatting 91, tegenover 491 sociaalpsychiatrisch verpleegkundigen. ${ }^{487}$ Een deel van de maatschappelijk werkenden is, al dan niet voltijds, actief binnen de Medisch Opvoedkundige Bureaus en de Bureaus voor Levens- en Gezinsmoeilijkheden. Goed twintig jaar later is de verhouding maatschappelijk werkenden versus verpleegkundigen ongeveer 600 tegen $1.125{ }^{488}$ In de periode 19891994 neemt het aantal maatschappelijk werkenden af met 23 procent en neemt het aantal verpleegkundigen toe met 40 procent. Daarvoor wordt als verklaring gegeven dat het maatschappelijk werk door zijn psychotherapeutische oriëntatie vanaf omstreeks 1970 taken kwijtraakt, die worden overgenomen door de verpleegkundigen. ${ }^{489}$ De verpleegkundigen en de maatschappelijk werkenden hebben blijkbaar verschillende professionele claims, waardoor ze zich op verschillende typen cliënten richten of verschillende werkwijzen hebben en niet met elkaar in aanraking komen.

De afname van het aantal maatschappelijk werkenden zet door in de jaren negentig. "Door de werkgevers in de GGZ worden beide beroepsgroepen weliswaar als gelijkwaardig en onderling inwisselbaar beschouwd, op de werkvloer wordt bijna altijd een keuze voor de SPV-ers gemaakt" ${ }^{490}$ De maatschappelijk werkenden hebben, voor een deel althans, taakopvattingen die niet stroken met de opvattingen van anderen. "Zij zien zich ook in de rol van (psycho)therapeut, gespecialiseerd op het gebied van psychosociale hulpverlening, aan vooral echtparen en gezinnen" ${ }^{491}$ De maatschappelijk werkenden onderscheiden zich onvoldoende van psychologen en psychotherapeuten en voor deze disciplines "is een dergelijke positie van de maatschappelijk werkenden nauwelijks acceptabel". ${ }^{492}$ Anders gezegd: het is de maatschappelijk werkenden binnen de Riagg's onvoldoende gelukt om een eigen claim overeind te houden. Elders is dat wel gelukt, zoals in het Algemeen Maatschappelijk Werk en in het personeelswerk van bedrijven en instellingen. Daar richten ze zich onder meer op het toepassen van regelingen, op arbeidsvoorwaarden en op bemiddeling bij individuele problemen.

De psychiaters zijn, zij het in wisselende mate, van grote invloed geweest op de ontwikkeling van de sociaalpsychiatrisch verpleegkundige beroepsgroep. De nadruk

\footnotetext{
${ }^{487}$ Romme, M.A.J. (red.) (1978). Voorzieningen in de geestelijke gezondheidszorg: een gids voor consument en hulpverlener. Alphen aan den Rijn; Brussel: Samsom, 24.

${ }^{488}$ Hutschemaekers, G., \& Neijmeijer, L. (1998). Beroepen in beweging: professionalisering en grenzen van een multidisciplinaire GGZ. Utrecht; Houten: Trimbos-Instituut; Bohn Stafleu Van Loghum, 181.

489 Ibidem, 58.

${ }^{490}$ Ibidem, 215.

${ }^{491}$ Ibidem.

492 Ibidem, 126.
} 
die de verpleegkundigen in deze studie hebben gekregen heeft geleid tot een zekere onderbelichting van die invloed. Anders gezegd: een meer op de psychiaters toegespitst onderzoek naar taakopvattingen en aspecten van samenwerking zou kunnen leiden tot een nuancering en completering van het hier ontstane beeld van de gang van zaken in de door verpleegkundigen en psychiaters zo sterk gevormde praktijk van de sociale psychiatrie.

\subsection{Tot besluit}

De minister van VWS heeft in 2003 het beleidsvoornemen uitgesproken dat de zorg voor de groep van naar schatting 60.000 chronische patiënten met complexe problemen een apart onderdeel zal worden van wat wordt genoemd de gespecialiseerde geestelijke gezondheidszorg. Blijkbaar verdwijnt het domein van de sociale psychiatrie niet, maar neemt het, zonder zo nog te worden genoemd, een andere vorm aan. Er bestaat blijkbaar een, weliswaar relatief kleine, groep mensen die het om allerlei redenen persoonlijk en maatschappelijk langdurig niet redt en die op zorg is aangewezen.

Er zijn twee goede redenen om die zorg te blijven verlenen. De eerste reden is de druk die de groep (niet alle leden ervan constant en in even hoge mate) legt op de directe leefomgeving en op de samenleving. Het hebben van een zoon of dochter met een dubbele diagnose brengt meer verdriet, zorg en angst mee dan menig ouder aankan en menig buitenstaander voor mogelijk houdt. Het onvoorspelbare, soms destructieve gedrag van sommigen met bijvoorbeeld een borderlinepersoonlijkheidsstoornis kan zeer deregulerend werken op allerlei zorg- en hulpverleningsdiensten en -instellingen en kost veel energie en geld. De tweede reden vormen de last en beperkingen die veel mensen uit bedoelde groep ervaren. Het niet hebben van werk, inkomen en goede huisvesting, het moeilijk of niet kunnen aangaan en onderhouden van contacten en intieme relaties, en dat alles langdurig en vaak in combinatie met elkaar, is op zijn zachtst gezegd een ontmoedigend vooruitzicht.

Het is dus zowel verstandig als humaan om de zorgverlening voor deze groep op peil te houden. Belangrijk criterium is dat de zorg laagdrempelig en toegankelijk is. $\mathrm{Nu}$ al blijkt dat patiënten zelf de weg naar sociaalpsychiatrisch verpleegkundigen in huisartspraktijken weten te vinden. Deze patiënten hebben, hoe het domein van de geestelijke gezondheidszorg ook wordt ingericht, en al zullen ze het zelf niet op deze manier verwoorden, kennelijk behoefte aan mensen die met verstand van zaken kunnen inschatten welk type zorg op zijn plaats is en hoe dat vervolgens kan worden gerealiseerd. Dat type zorg kan, om het in termen van Orem's Self-Care Deficit Theory of Nursing uit te drukken, variëren van "supportive educative" en "partly 
compensatory" tot "wholly compensatory" activiteiten. ${ }^{493}$ Vanouds hoort dat soort activiteiten tot het domein van de verpleegkunde. Goed opgeleide verpleegkundigen komen in aanmerking om dat werk te verrichten. Hoe ze verder worden genoemd is van ondergeschikt belang.

${ }^{493}$ Orem, D.E. (2001). Nursing: concepts of practice. St. Louis: Mosby, 350. 


\section{Naamgeving van de verpleegkundigen in de sociale psychiatrie door de jaren heen}

Nomen est omen of: de naam is een voorteken, de naam zegt iets over iemands lot. Ook indien deze uitspraak niet letterlijk wordt genomen, dan nog is het interessant om te bekijken hoe de verpleegkundigen in de extramurale psychiatrie door de tijd heen zijn genoemd en of dat iets zegt, en wat dan wel, over de kijk op hun functie.

Onderstaande voorbeelden zijn, met uitzondering van de met * gemerkte, voor zover bekend, gebruikt door niet-verpleegkundigen, door artsen, psychiaters en beleidsmakers.

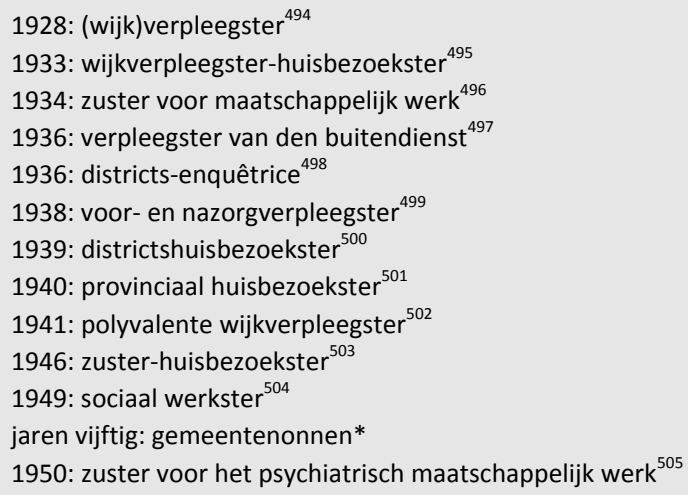

\footnotetext{
${ }^{494}$ Beijerman, W. (1928). Verzorging van zenuw- en geesteszieken in de maatschappij: handleiding in het bijzonder voor wijkverplegenden. Groningen; Den Haag: Wolters, 137.

${ }^{495}$ Veeger, L. (1933). Geestelijke gezondheidszorg en de wijkverpleegster-huisbezoekster. Katholieke Gezondheidszorg, 4, 158-161, 158.

${ }^{496}$ Querido, A. (1980). Doorgaand verkeer: autiobiografische fragmenten. Lochem-Poperinge: De Tijdstroom, 137.

${ }^{497}$ Verslag St. Anna (1936). In Vereeniging van R.K. Gestichten en Inrichtingen voor Krankzinnigen en Zwakzinngen. Achtste jaarboek der Vereeniging van R.K. Gestichten en Inrichtingen voor Krankzinnigen en Zwakzinngen, 26.

${ }^{498}$ Willemsen, C. (2001). De belofte van het hiernumaals: zeventig jaar ambulante geestelijke gezondheidszorg in het gewest Breda 1929-1999. Nijmegen: SUN, 51.

${ }^{499}$ Verslag St. Anna (1938). In Vereeniging van R.K. Gestichten en Inrichtingen voor Krankzinnigen en Zwakzinnigen. Tiende jaarboek der Vereeniging van R.K. Gestichten en Inrichtingen voor Krankzinnigen en Zwakzinnigen, 30.

${ }^{500}$ Verslag St. Anna (1939). In Vereeniging van R.K. Gestichten en Inrichtingen voor Krankzinnigen en Zwakzinnigen. Elfde jaarboek der Vereeniging van R.K. Gestichten en Inrichtingen voor Krankzinnigen en Zwakzinnigen, 29.

${ }^{501}$ R.K. Vereeniging Het Limburgsche Groene Kruis (1940). Jaarverslag R.K. Vereeniging Het Limburgsche Groene Kruis. [S.I.]: R.K. Vereeniging Het Limburgsche Groene Kruis, 135.

${ }^{502}$ Grinten, T.E.D. van der (1987). De vorming van de ambulante geestelijke gezondheidszorg: een historisch beleidsonderzoek. Baarn: Ambo, 183.

${ }^{503}$ Verslag St. Servatius (1946). In Vereeniging van R.K. Gestichten en Inrichtingen voor Krankzinnigen en Zwakzinnigen. Dertiende jaarboek der Vereeniging van R.K. Gestichten en Inrichtingen voor Krankzinnigen en Zwakzinnigen, 12.

${ }^{504}$ Ibidem, 255.
} 


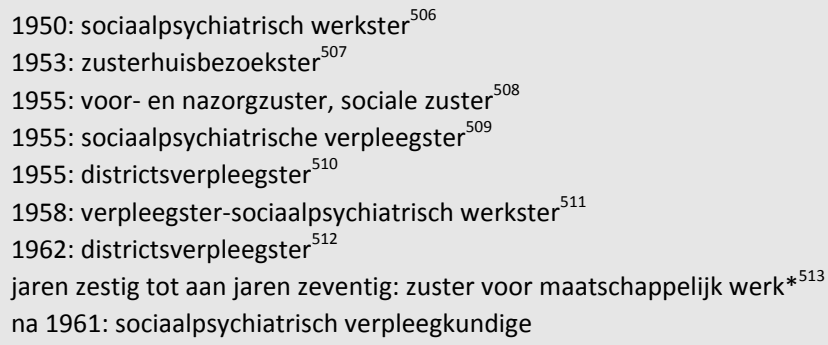

Welke betekenis kan aan de verschillende benamingen worden toegekend, of, in dit geval, in hoeverre zeggen de benamingen iets over het domeinperspectief van degenen die ze gebruiken?

De termen districts- en provinciaal huisbezoekster, districts-enquêtrice en districtsverpleegster worden gebruikt daar waar de voor- en nazorg provinciaal en districtsgewijs is georganiseerd, veelal door kruisorganisaties. Deze organisaties kennen de functie districtsverpleegkundige ook in de somatische zorg. Het gaat dan om regionaal opererende, gespecialiseerde wijkverpleegkundigen op het gebied van bijvoorbeeld tuberculose.

Uit inrichtingsverslagen afkomstig zijn de termen verpleegster van den buitendienst, voor- en nazorgzuster (met uitzondering van referentie 16) en zuster-huisbezoekster. Hieruit kan worden geconcludeerd dat de naamgeving wijst op werkzaamheden buiten de inrichting, na ontslag van de patiënten.

De titels wijkverpleegster-huisbezoekster en polyvalente wijkverpleegster hebben betrekking op wijkverpleegkundigen in de psychiatrische voor-en nazorg.

Het gebruik van de naam zuster voor (psychiatrisch) maatschappelijk werk is gerelateerd aan de Amsterdamse GG\&GD. In de naamgeving wordt de maatschappelijke oriëntatie die in werk en geschrift van Querido herkenbaar is, weerspiegeld.

In de andere benamingen komt het bijvoeglijk naamwoord sociaal voor. Dat kan worden gezien als een verwijzing naar de sociale rol die de verpleegkundigen wordt toebedacht.

De uitzonderingen waarin de benamingen worden gebruikt door de verpleegkundigen hebben betrekking op Amsterdam. Ze noemen zich tot eind jaren veertig in hun aantekeningen zuster. In de jaarverslagen van de GG\&GD worden de verpleegkundigen vanaf 1962 sociaalpsychiatrisch verpleegkundigen

${ }^{505}$ Hart De Ruyter, Th. (1950). De afdeling geestelijke hygiëne. Tijdschrift voor Sociale Geneeskunde, 28, 538-550, 538. Niet uitgesloten is dat de naam al vanaf 1934, wanneer Querido in Amsterdam de afdeling begint, gebruik wordt naast de naam zuster voor maatschappelijk werk.

${ }^{506}$ Ibidem, 542. Zie commentaar bij de vorige verwijzing.

${ }^{507}$ Verslag St. Servatius (1953). In Vereeniging van R.K. Gestichten en Inrichtingen voor Krankzinnigen en Zwakzinnigen. Zestiende jaarboek der Vereeniging van R.K. Gestichten en Inrichtingen voor Krankzinnigen en Zwakzinnigen, 11.

${ }^{508}$ Trimbos, C.J.B.J. (1955). De ontwikkeling der voor- en nazorgdiensten in het kader der geestelijke gezondheidszorg. Maandblad Geestelijke Volksgezondheid, 10, 53-62, 56, 58.

${ }^{509}$ Barnhoorn, J.A.J. (1955). Sociale psychiatrie, geestelijke hygiëne, geestelijke gezondheidszorg en geestelijke volksgezondheid. Maandblad Geestelijke Volksgezondheid, 10, 1-40, 13.

${ }^{510}$ Verslag St. Servatius (1955). In Vereeniging van R.K. Gestichten en Inrichtingen voor Krankzinnigen en Zwakzinnigen. Achttiende jaarboek der Vereeniging van R. K. Inrichtingen voor Krankinnigen en Zwakzinnigen, 14.

${ }^{511}$ Barnhoorn, J.A.J. (1958). Sociaal-psychiatrische casuïstiek. Leiden, Stenfert Kroese, 25.

${ }^{512}$ Sociaal-psychiatrische dienst te weinig bekend: interview met zuster N. van der Hek. Katholieke GezondheidsZorg, 1962, 3, 98-99, 98.

${ }^{513}$ Ibidem.

${ }^{514}$ Akkermans, C. Aanspoelen aan de Achtergracht: maatschappelijke ontwikkelingen, clientèlevormingen de psychiatrische patiënten van de Amsterdamse GG\&GD (1933-1988), 177. 
genoemd. Ze ondertekenen tot in de jaren zestig brieven met zuster voor maatschappelijk werk, vanaf de jaren zeventig met sociaalpsychiatrisch verpleegkundige.

In de volksmond worden de verpleegkundigen in Amsterdam ook wel gemeentenonnen genoemd omdat ze een verpleegstersuniform, gemeentelijke overjas en "gemeentehoedje" dragen. ${ }^{514}$

$\mathrm{Na}$ de vorming van de Sociaal-Psychiatrische Diensten in 1961 raakt de naam sociaalpsychiatrisch verpleegkundige ingeburgerd en raken andere benamingen in onbruik. Dat geldt ook voor de naam nazorgzuster die lange tijd in zwang is geweest.

Ofschoon in de wet Big de titel sociaalpsychiatrisch verpleegkundige niet voorkomt, blijft de benaming, niet in het minst bij de verpleegkundigen zelf, tot op heden gangbaar. Er bestaat, weliswaar niet meer als zelfstandige vereniging, nog steeds de afdeling sociaalpsychiatrisch verpleegkundigen van V\&VN. Of die naam nog lang zal worden gebezigd, is de vraag. Het domein van de sociale psychiatrie bestaat onder die noemer niet meer, de titel sociaalpsychiater is nauwelijks nog gangbaar. Waarom zouden de verpleegkundigen de uitzondering zijn? 


\section{Bronnen en literatuur}

\section{Archieven}

Sociaal Historisch Centrum voor Limburg, Maastricht. R.K. Vereeniging Het Limburgsche Groene Kruis. Archief 1936.

Sociaal Historisch Centrum voor Limburg, Maastricht. Archieven St. Anna Venray 1938-1973.

Sociaal Historisch Centrum voor Limburg, Maastricht. Archieven St. Servatius Venray 1938-1973.

\section{Jaarboeken}

Jaarboek der Vereeniging van R.K. Gestichten en Inrichtingen voor Krankzinnigen en Zwakzinnigen 1934, 1935, 1936, 1940, 1946, 1954,

Jaarboek van de Katholieke Vereniging voor Behandeling en Verpleging van Geestelijk Gestoorden, 1958

\section{Jaarverslagen}

Jaarverslag Stichting Geestelijke Gezondheidszorg Maastricht e.o. 1960-1972

Jaarverslag R.K. Vereeniging/Vereniging Het Limburgsche Groene Kruis 1934-1936, 1955-1956, 1964/1967, 1968/1972

\section{Literatuur}

Abbott, A. (1988). The system of professions: an essay on the division of expert labor. Chicago; London: University of Chicago Press.

Abel-Smith, B. (1979). A history of the nursing profession. London: Heinemann.

Abma, R., \& Weijers, I. (2005). Met gezag en deskundigheid: de historie van het beroep psychiater in Nederland. Amsterdam: SWP.

Adriaansens, H. P. M., \& Zijderveld, A. C. (1981). Vrijwillig initiatief en de verzorgingsstaat: cultuursociologische analyse van een beleidsprobleem. Deventer: Van Loghum Slaterus.

Advies inzake een beleid voor psychotherapie (1981). Bulletin Nederlandse Vereniging van SociaalPsychiatrisch Verpleegkundigen, 1-2.

Akkermans, C. (2006). Aanspoelen aan de Achtergracht: maatschappelijke ontwikkelingen, clientèlevorming en de psychiatrische patiënten van de Amsterdamse GG\&GD (1933-1988). Amsterdam: Aksant.

Alem, V. van, Fransman, J., Heijden, H. van der, Jonkers, F., Limbeek, J. van, \& Wouters, L. (1991). Querido's legacy. Amsterdam: Municipal Health Service.

Anderson, G. L. (1930). The scope and aim of a mental hygiene program in a public health nursing association. Public Health Nurse(22), 377-379.Antonia-Wilhelmina-Fonds (1932). De rol van de wijkverpleging bij de huiselijke zorg van zenuw- en zielszieken. Zesde conferentie door den Raad van Bestuur van het Antonia Wilhelmina Fonds, Utrecht.

Bailey, H. (1936). Nursing schools in psychiatric hospitals. American Journal of Nursing, 36, 495-508.

Bakker-van der Kooij, C. (1981). Mara, pleegzuster zijn: ontwikkelingen in de ziekenverpleging en de organisatiepogingen van verpleegsters in Nederland, 1817-1920. In J. Blok et al. (eds.), Jaarboek voor vrouwengeschiedenis. Nijmegen: Socialistiese Uitgeverij. 
Bakker, H., Goei, L. de, \& Vijselaar, J. (1994). Thuis opgenomen: uit de geschiedenis van de sociale psychiatrie in Nederland. Utrecht: NcGv.

Bambang Oetomo, R. (1974). Patiënt, arts en verplegende: hun onderlinge betrekkingen toen en nu. Tijdschrift voor Psychiatrie, 16, 387-413.

Barnhoorn, J. A. J. (1955). Sociale psychiatrie, geestelijke hygiëne, geestelijke gezondheidszorg en geestelijke volksgezondheid. Maandblad Geestelijke Volksgezondheid, 10(bijlage februarinummer), 1-40.

Barnhoorn, J. A. J. (1958). Sociaalpsychiatrische casuïstiek. Leiden: Stenfert Kroese.

Beek, H. van de, \& Hutschemaekers, G. (1992). De psychiatrische polikliniek voor het voetlicht. Maandblad Geestelijke Volksgezondheid, 47(9), 939-954.

Beijerman, W. (1923). De sociale zijde der psychiatrie. Nederlands Tijdschrift voor Geneeskunde, 67, 7478.

Beijerman, W. (1928). Verzorging van zenuw- en zielszieken in de maatschappij: handleiding in het bijzonder voor wijkverplegenden. Groningen; Den Haag: Wolters.

Bell, N. W., \& Spiegel, J. P. (1966). Social psychiatry: vagaries of a term. Archives of General Psychiatry, 14, 337-345

Benson, J. K. (1975). The interorganizational network as a political economy. Administrative Science Quarterly, 20, 229-249.

Billekens, A. J., Boeck, L. de, Els, T. van, Jaarsveld, T. van, Jansen, P., Kroft, A., et al. (2005). 100 Jaar psychiatrie in Venray: geschiedenis van de psychiatrische instellingen Sint Anna en Sint Servatius. Zutphen: Walburg Pers.

Binnenkade, C. (1973). Honderd jaar opleiding tot verpleegkundige in Nederland 1872-1972: een terreinverkenning. Leiden: Stafleu's Wetenschappelijke Uitgeversmij.

Blok, G. (2004). Baas in eigen brein: 'antipsychiatrie' in Nederland, 1965-1985. Amsterdam: Uitgeverij Nieuwezijds.

Blok, G., \& Vijselaar, J. (1998). Terug naar Endegeest: patiënten en hun behandeling in het psychiatrisch ziekenhuis Endegeest 1897-1997. Nijmegen: SUN.

Boer, N. de (1995). Riagg's hebben hun doel bereikt. De Gazet, 8, 6-8.

Boom, H. v. d., Philipsen, H., \& Stevens, F. (2004). Een schets van de professionalisering van de wijkverpleging in Nederland in de laatste vijftig jaar (1950-2004). Gewina, 27, 100-119.

Boom, H. van der (2008). Home nursing in Europe: patterns of professionalisation and institutionalisation of home care and family care to elderly people in Denmark, France, the Netherlands and Germany. Amsterdam: Aksant.

Boschma, G. (1997). Psychiatrische verpleegkunde: een historisch perspectief. Maandblad Geestelijke Volksgezondheid, 52, 959-976.

Boschma, G. (1999). High ideals versus harsh reality: a historical analysis of mental health nursing in Dutch asylums, 1890-1920. Nursing History Review, 7, 125-151.

Bouman, H. (1932). Eventuele taak van het Groene Kruis in de organisatie voor geestelijke volksgezondheid. Het Groene en Witte Kruis, 28, 226-237.

Bouman, K. H. (1929). Over sociale psychiatrie. Psychiatrische en Neurologische Bladen, 33, 133-148.

Bouwmans, M. (2008). Praktijkondersteuner GGZ: belangrijke motor voor ontwikkeling eerstelijns GGZ. Sociale Psychiatrie, 27(87), 56-58.

Brink, C. J. (2000). Gekwalificeerd voor de thuiszorg: een onderzoek naar de inzetbaarheid van de intramuraal werkende, inservice opgeleide psychiatrisch verpleegkundige in de psychiatrisch intensieve thuiszorg. Doctoraalscriptie Universiteit Maastricht, Maastricht.

Brinkgreve, C. (1982). De zorg voor zenuwlijders in Nederland rond de eeuwwisseling en de opkomst van de psychoanalyse. In J. M. W. Binneveld, C. Brinkgreve, A. J. Lameijn, H. F. M. Peeters, P. Vandermeersch, C. P. de Vos \& J. Vijselaar (eds.), Een psychiatrisch verleden: uit de geschiedenis van de psychiatrie. Baarn: Ambo.

Brouns, G. (1993). Zelfzorgtheorie van Orem. Dwingeloo: Kavannah.

Brouns, G., Diederiks, J. P. M., \& Philipsen, H. (2003). Sociaalpsychiatrische verpleegkunde in Nederland 1917-1937. Verpleegkunde, 18, 93-102. 
Brouns, G., Philipsen, H., Diederiks, J., \& Meertens, P. (2007). Sociale psychiatrie in de provincie Limburg tot omstreeks 1975: van achterstand tot voorsprong. In A. Knotter \& W. Rutten (eds.), Studies over de sociaal-economische geschiedenis van Limburg (vol. 52, pp. 137-157). Maastricht: Sociaal Historisch Centrum voor Limburg.

Caplan, R. (1969). Psychiatry and the community in nineteenth-century America: the recurring concern with the environment in the prevention and treatment of mental illness. New York: Basic Books.

Carpenter, M. (1980). Asylum nursing before 1914: a chapter in the history of labour. In C. Davies (Ed.), Rewriting nursing history. London: Croom Helm/Totowa: Barnes \& Noble.

Centraal Bureau voor de Statistiek (2004). Statistisch jaarboek 2004. Voorburg; Heerlen: CBS.

Centraal Bureau voor de Statistiek (2007). Statistisch Jaarboek 2007. Voorburg; Heerlen: CBS.

Church, O. M. (1982). That noble reform: the emergence of psychiatric nursing in the United States 18821963. Ann Arbor: University Microfilms International.

Church, O. M. (1986). From custody to community in psychiatric nursing. Nursing Research, 36, 48-55.

Coördinerend Orgaan Nascholing en Opleiding in de GGZ (2006). GGZ verpleegkundige specialist. S.I.: Coördinerend Orgaan Nascholing en Opleiding in de GGZ.

Cornips, J. (1952). Bijdrage tot de geschiedenis van de krankzinnigenzorg te Maastricht. Maastricht: Burgerlijk Armbestuur; Sociaal Historisch Centrum.

Cox, W. H. (1927). Handleiding voor den cursus in de verpleging van zielszieken. I: Eerste cursusjaar. Amsterdam: J.H. de Bussy.

Cox, W. H. (1929). Handleiding voor den cursus in de verpleging van zielszieken. II: Tweede cursusjaar. Amsterdam: J.H. de Bussy.

Dankers, J., \& Linden, J. van der (1996). Van regenten en patiënten: de geschiedenis van de Willem Arntsz Stichting: Huis en Hoeve, Van der Hoevenkliniek en Dennendal. Amsterdam; Meppel: Boom.

Davies, C. (1980). A constant casualty: nurse education in Britain and the USA to 1939. In C. Davies (ed.), Rewriting nursing history. London: Croom Helm/Totowa: Barnes \& Noble.

Deutsch, A. (1940). The convergence of social work and psychiatry: an historical note. Mental Hygiene, 24, 92-97.

Doeve, E. (1980). Een analyse van het sociaalpsychiatrisch verpleegkundige beroep volgens het beroeps(vormings)model van Mok. Doctoraalscriptie Rijksuniversiteit Groningen, Groningen.

Dorgan, R. E. (1970-1971). From demonology to scientific humanitarianism: social casework specializes. International Journal of Social Psychiatry, 17, 20-38.

Ehrenreich, J. H. (1985). The altruistic imagination: a history of social work and social policy in the United States. Ithaca; London: Cornell University Press.

Esch, P. van der (1975-1980). Geschiedenis van het Staatstoezicht op Krankzinnigen. Leidschendam: Ministerie van Volksgezondheid en Milieuhygiëne.

Esser, P. H. (1970-1971). Sociale psychiatrie. Kampen: J.H. Kok.

Eynde, I. E. I. M. van (1978). Enkele nieuwe woonvormen voor psychiatrische patiënten. Tijdschrift voor Psychiatrie, 20, 79-94.

Falkenstein, D. (2000). "Ein guter Wärter ist das vorzüglichste Heilmittel...": zur Entwicklung der Irrenpflege vom Durchgangs- zum Ausbildungsberuf. Frankfurt am Main: Mabuse Verlag.

Falthauser, V. (1927). Die speziellen Gesichtspunkte für die Organisation der Offenen Geisteskrankenfürsorge: Fürsorgepfleger. In H. Roemer, G. Kolb \& V. Faltlhauser (eds.), Die offene Fürsorge in der Psychiatrie und ihren Grenzgebiete. Berlin: Verlag von Julius Springer.

Festen, T., \& Heringa, M. (1997). Van dichtbij en veraf: 15 jaar RIAGG/25 jaar NVAGG. Utrecht: NVAGG.

Finzen, A. (1998). Das Pinelsche Pendel: Dimensionen des Sozialen im Zeitalter der biologischen Psychiatrie. Bonn: Das Narrenschiff.

Fischer, M. (1912). Neue Aufgaben der Psychiatrie in Baden. Allgemeine Zeitschrift für Psychiatrie und Psychisch-gerichtliche Medizin, 69, 34-68.

Fischer, M. (1919). Die soziale Psychiatrie im Rahmen der sozialen Hygiene und allgemeinen Wohlfartspflege. Allgemeine Zeitschrift für Psychiatrie und Psychisch-gerichtliche Medizin, 76, 529548. 
Foudraine, J. (1971). Wie is van hout.... een gang door de psychiatrie. Baarn: Ambo.

Frankenstein, G. (1927). Psychiatrische Sozialarbeit in den Vereinigten Staaten von Amerika. Zeitschrift für die Gesamte Neurologie und Psychiatrie, 325-336.

French, L. M. (1940). Psychiatric social work. New York: Commonwealth Fund.

Frets, F. W. (1986). Van verheffing tot behandeling: ontwikkeling van de practische sociale psychiatrie. In J. Vijselaar (ed.), Ambulant in zicht: geschiedenis van de ambulante geestelijke gezondheidszorg in Nederland. Utrecht: NcGv.

Functieprofiel startdocument PraktijkOndersteuner Huisartsenzorg POH-GGZ 2008.

Geneeskundige Inspectie voor de Geestelijke Volksgezondheid (1993). 100 Jaar diploma Bverpleegkunde. Rijswijk: Staatstoezicht op de Volksgezondheid.

Gersons, B. P. R. (1994). Verpleegkundige wordt casemanager: transformatie en opkomst van een "zwijgende meerderheid". Sociale Psychiatrie, 13(36).

Geschiedenis St. Anna en St. Servatius en Pachalis (gebundelde reader) (2002). Venray: Vincent van Gogh Instituut.

Goei, L. de (2001). De psychohygiënisten: psychiatrie, cultuurkritiek en de beweging voor geestelijke volksgezondheid in Nederland, 1924-1970. Nijmegen: SUN.

Goffman, E. (1961). Asylums: essays on the social institution of mental patients and other inmates. Garden City: Anchor Books.

Grinten, T. E. D. van der (1987). De vorming van de ambulante geestelijke gezondheidszorg: een historisch beleidsonderzoek. Baarn: Ambo.

Grob, G. N. (1991). From asylum to community: mental health policy in modern America. Princeton, NJ: Princeton University Press.

Hall, R. H. (1988). Comment on the sociology of the professions. Work and Occupations, 15(3), 273-275.

Hart de Ruyter, T. (1950). De afdeling geestelijke hygiëne. Tijdschrift voor Sociale Geneeskunde, $28(22$ december), 538-550.

Haselbeck, H. (1985). Zur Sozialgeschichte der "Offenen Irren-Fürsorge": vom Stadtasyl zum sozialpsychiatrischen Dienst. Psychiatrische Praxis, 12, 171-179.

Havermans, F. M., \& Oosterbaan, W. M. (1954). Sociale psychiatrie voor maatschappelijk werkenden. Roermond; Maaseik: Romein.

Heerma van Voss, A. J. (1991). Querido, een levensverhaal. Maandblad Geestelijke Volksgezondheid, 46, 722-811.

Henselmans, H. (1993). Bemoeizorg: ongevraagde hulp voor psychotische patiënten. Delft: Eburon.

Hermans, E. (2000). In het verkeerde bed: het zorgtraject van een cohort CVA-patiënten na ziekenhuisopname. Proefschrift Universiteit Maastricht, Maastricht.

Hodiamont, P. P. G., Berting, M., \& Hezewijk, W. J. M. van (1998). Cultuurverschillen binnen een integrerende GGZ-instelling. Tijdschrift voor Psychiatrie, 40, 231-237.

Hoffmann-Richter, U., \& Finzen, A. (1995). Sozialpsychiatrie-Spezialdisziplin oder Sichtweise?: Entwicklungsgeschichte des Begriffs und seiner Bedeutung. In A. Finzen \& U. Hoffmann-Richter (eds.), Was ist Sozialpsychiatrie?: eine Chronik (pp. 11-19). Bonn: Psychiatrie-Verlag.

Hoof, F. van, \& Wolf, J. (1995). Beroep: SPV: een onderzoek naar werk en toekomstperspectieven van sociaalpsychiatrisch verpleegkundigen. Utrecht: NcGv.

Horn, G. H. M. M. te (1979). Voorzorg, nazorg, geen zorg: de samenwerking tussen de ambulante en de klinische GGZ. Maandblad Geestelijke Volksgezondheid, 34, 669-672.

Houten, D. van (2006). Professionalisering en arbeidsdeling. Sociale Interventie, 15(2), 17-25.

Hutschemaekers, G. (2000). Wordt Nederland steeds zieker?: kengetallen en achtergrondanalyses. Maandblad Geestelijke Volksgezondheid, 55, 314-335.

Hutschemaekers, G., \& Neijmeijer, L. (1998). Beroepen in beweging: professionalisering en grenzen van een multi-disciplinaire GGZ. Utrecht: Trimbos-instituut/Houten: Bohn Stafleu Van Loghum.

Hutschemaekers, G. J. M., \& Oosterhuis, H. (2004). Psychotherapy in the Netherlands after the second world war. Medical History, 48, 429-448. 
Hutschemaekers, G. J. M., \& Tiemens, B. G. (2006). Het einde van de sectorale ggz: ontwikkelingen, trends en controverses in Nederland. Tijdschrift voor Psychiatrie, 48, 27-37.

Ilberg, G. (1904). Soziale Psychiatrie. Monatsschrift für Soziale Medizin, 1, 321-329, 393-328.

Illich, I. D., Zola, I. K., \& MacNight, J. (1977). Disabling professions. London: Boyars.

Jabaaij, L., \& Hutschemaekers, G. (1998). Vraag en aanbod in de Paaz: een praktijkstudie vanuit het perspectief van patiënten en behandelaars op de psychiatrische afdelingen van algemene ziekenhuizen. Utrecht: Trimbos-instituut.

Kamphuis, M. (1948a). Amerika en wij: wat valt er voor ons maatschappelijk werk te leren? Tijdschrift voor Maatschappelijk Werk, 2, 49-52.

Kamphuis, M. (1948b). Het Amerikaanse social case work. Tijdschrift voor Maatschappelijk Werk, 2, 8185.

Klinische les: verschrikkelijke ziektes (1985). Sociale Psychiatrie, 5(16), 13.

Koekkoek, B., Meijel, B. K. G. van, Schene, A., \& Hutschemaekers, G. (2008). Sociaalpsychiatrisch verpleegkundigen in Nederland: een enquête. Sociale Psychiatrie, 27(87), 47-56.

Koerselman, F. (1998). Classificatie en psychotherapie. Maandblad Geestelijke Volksgezondheid, 53, 1064-1068.

Kolb (1920). Inwieweit sind Änderungen im Betriebe der Anstalten geboten?: Referat, erstattet der Hamburger Tagung des Deutschen Vereins für Psychiatrie. Psychiatrisch-Neurologische Wochenschrift, 21/22, 163-176.

Kool, J. (2000). De psychiater, de verpleegkundig specialist en de sociale psychiatrie: wie bewaakt de ontwikkeling van dit vakgebied? Maandblad Geestelijke Volksgezondheid, 55, 1033-1041.

Koppert, C. (1976). De sociaalpsychiatrische verpleegkundige en gezinsbehandeling. Lochem: De Tijdstroom.

Kraepelin, E. (1918). Hundert Jahre Psychiatrie. Zeitschrift für die Gesamte Neurologie und Psychiatrie, 38, 161-275.

Kukla, R. (1973). Zur Sozialisation der Krankenschwestern in der Psychiatrie. Kölner Zeitschrift für Soziologie und Sozialpsychologie, 25, 484-498.

Kwast, S. van der (1974). Vijftig plus: de geschiedenis van de Dr. F.S. Meijersvereniging. In S. van der Kwast (ed.), Het einde van onbegonnen werk?: vijftig jaar sociaalpsychiatrisch reclasseringswerk van de Dr. F.S. Meijers-Vereniging (pp. 11-29). Meppel: Boom.

Laat, F. C. M. de (198X). Van psychiatrische verpleegkundige tot ... : een historisch overzicht van de ontwikkelingen rond psychiatrische verpleegkunde in de periode 1920-1980. Doctoraalscriptie Universiteit van Amsterdam, Amsterdam.

Laing, R. D. (1960). The divided self: a study of sanity and madness. London: Tavistock.

Landelijke Commissie Geestelijke Volksgezondheid (2002). Zorg van velen: eindrapport van de Landelijke Commissie Geestelijke Volksgezondheid. Den Haag: Ministerie van VWS.

Larkin, K. O. (1931). What education does the psychiatric social worker need? Psychiatric Quarterly, 5, 723-732.

Ledenraadpleging V\&VN-SPV 2006 (2006). [Amsterdam]: Noordam \& De Vries.

Lendering, J., \& Meer, J. van der (2002). Volksgezondheidssubsidies: een institutioneel onderzoek naar het beleidsinstrument subsidiëring op het terrein van de volksgezondheid 1945-1997. Den Haag: Rijksarchiefdienst; PIVOT; Ministerie van Volksgezondheid, Welzijn en Sport.

Lidz, T. (1966). Adolf Meyer and the development of American psychiatry. American Journal of Psychiatry, 123, 320-332.

Lief, A. (1948). The commonsense psychiatry of Dr. Adolf Meyer: fifty-two selected papers. New York [etc.]: McGraw Hill.

Lieshout, P. van (1985). Veertig jaar geestelijke volksgezondheid: een analyse van het MGv. Maandblad Geestelijke Volksgezondheid, 40, 1243-1274.

Lohuis, G., Polstra, L., \& Schout, G. (2004). Creativiteit in knellende omstandigheden: omgaan met knellende omstandigheden in de zorg voor kwetsbare mensen. Amsterdam: SWP. 
Lohuis, G., Schilperoort, R., \& Schout, G. (2000). Van bemoei- naar groeizorg: methodieken in de OGGz. Groningen: Wolters-Noordhoff.

Londen, J. van (2001). Opkomst en neergang van de sociale psychiatrie: kan het boek van de sociale psychiatrie al worden gesloten en terzijde gelegd? Utrecht: Trimbos-instituut.

Lubove, R. (1983). The professional altruist: the emergence of social work as a career, 1880-1930 (8th ed.). New York: Atheneum.

Lumeij, J. L. J. (1961). Het werk van de Sociaal-Psychiatrische Dienst: een kritische bezinning op de huidige werkwijze en inhoud van het werk. Maandblad Geestelijke Volksgezondheid, 16, 207-218.

Maso, I., \& Smaling, A. (1998). Kwalitatief onderzoek: praktijk en theorie. Amsterdam: Boom.

Mastboom, J. (1981). Poliklinieken van psychiatrische centra: een beschrijvend onderzoek naar ontstaan, werkwijze, personeelsopbouw, taken en funkties van de psychiatrische poliklinieken van psychiatrische centra ( $\left.p p c^{\prime} s\right)$ en een nadere positiebepaling binnen de geestelijke gezondheidszorg in Nederland in 1978. Utrecht: NcGv.

May, M. E. (1893, reprint 1949). Nursing of the insane. In I. A. Hampton et al. (eds.), Nursing of the sick. New York: McGraw-Hill.

Meijers, F. S. (1939). De voor- en nazorg van geestelijk hulpbehoevenden. Amsterdam: Centrale Vereeniging ter Behartiging der Maatschappelijke Belangen van Zenuw- en Zielszieken.

Meinema, T. (1922). Over gezinsverpleging van geesteszieken. Amsterdam: Antonia Wilhelmina Fonds.

Meyer, A. (1922). Historical sketch and outlook of psychiatric and social work. Hospital Social Service, 5, 221-225.

Ministerie van VWS (1989). Beleidsvisie geestelijke gezondheidszorg 1999. Den Haag: Ministerie van VWS.

Ministerie van VWS (2003). Brief van de minister van Volksgezondheid, Welzijn en Sport aan de Tweede Kamer der Staten-Generaal van 28-11-2003. Den Haag: Ministerie van VWS.

Ministerie van VWS (2007). Brief van de minister van Volksgezondheid, Welzijn en Sport aan de Tweede Kamer der Staten-Generaal van 11-7-2007. Den Haag: Ministerie van VWS.

Möllenhoff, H. (1992). Zur Geschichte des Pflegepersonals. In P. Eller \& C. Vanja (eds.), Psychiatrie in Heppenheim: Streifzüge durch die Geschichte eines hessischen Krankenhauses 1866-1991. Kassel: Landeswohlfartverband Hessen.

Müller, M. (1982). Erinnerungen: erlebte Psychiatriegeschichte 1920-1960. Berlin [etc.]: Springer.

Nederlandse Vereniging van Sociaal Psychiatrisch Verpleegkundigen (2004). Congres ter gelegenheid van het vijfentwintigjarig bestaan van de vereniging in december 2004. Jubileumcongres 'Een brede aanpak in 2004', VU Amsterdam, 9-10 december 2004.

Nederlandse Vereniging voor Ambulante Geestelijke Gezondheidszorg (1981). De PSV tussen opleiding en werkveld: nota van de Werkgroep Eindpunt Opleiding SPV. Utrecht: NVAGG.

Nederlandse Vereniging voor Ambulante Geestelijke Gezondheidszorg, Nederlandse Vereniging van Sociaalpsychiatrisch Verpleegkundigen, \& Vereniging ter Behartiging van de Belangen van het Gezondheidszorgonderwijs (1987). Inzetbaarheid HBO-verpleegkundigen als spv. Utrecht: NVAGG [etc.].

Nederlandse Vereniging voor Psychiatrie en Neurologie, \& Nationale Federatie voor Geestelijke Volksgezondheid (1969). Rapport betreffende de opleiding tot verpleegkundige voor sociaalpsychiatrisch werk: Nederlandse Vereniging voor Psychiatrie en Neurologie; Nationale Federatie voor Geestelijke Volksgezondheid.

Nolan, P. (1993). A history of mental health nursing. Cheltenham: Stanley Thornes.

NU'91 (2008). Mededeling ledenadministratie NU'91, 01-12-2008.

Odencrantz, L. C. (1929). The social worker in family, medical and psychiatric social work. New York: Harper.

Onderwater, K., Padt, I. van der, \& Leeuw, M. de (1999). Verpleegkundigen, verantwoordelijke partners in de GGZ. Maandblad Geestelijke Volksgezondheid, 54, 369-375.

Onderwater, K., Padt, I. van der, Romme, M., Venneman, B., \& Verberk, F. (2004). Sociale psychiatrie: visie, theorie en methoden van een maatschappelijk georiënteerde psychiatrie. Utrecht: Lemma.

Oosterhuis, H. (2004). Between institutional psychiatry and mental health care: social psychiatry in the Netherlands, 1916-2000. Medical History, 48, 413-428. 
Oosterhuis, H., \& Wolters, S. (1998). The changing professional identity of the Dutch psychiatrists $1960-$ 1997. In M. Gijswijt-Hofstra \& R. Porter (eds.), Cultures of psychiatry and mental health care in postwar Britain and the Netherlands. Amsterdam [etc.]: Rodopi.

Orem, D. E. (2001). Nursing: concepts and practice. St. Louis: Mosby.

Overbosch, J. F. A. (1928). De nazorg van geesteszieken door het gesticht in het grootestadsmilieu. Psychiatrische en Neurologische Bladen, 32(bijblad Neurotherapie), 17-25.

Padt, I. van der (1999). Hoopvol bezorgd: sociaal psychiatrische verpleegkunde van de 20e naar de 21 e eeuw. Eindhoven: Nederlandse Vereniging van Sociaal Psychiatrisch Verpleegkundigen.

Palm, A. F. B. L. (1997). De opleiding tot sociaalpsychiatrisch verpleegkundige 1970-1995: een historisch onderzoek. Doctoraalscriptie Universiteit Maastricht, Maastricht.

Pameyer, J. (1928a). De buitendienst van "Maasoord". Conferentie gehouden door den Raad van Bestuur van Het Antonia Wilhelminafonds.

Pameyer, J. (1928b). Plaatsing in de maatschappij van geestelijk onvolwaardigen. Amsterdam: De Bussy.

Pameyer, J. (1932). Over voor- en nazorg van geesteszieken. Inleiding voor het 37e Gezondheidscongres, Amsterdam.

Panke-Kochinke, B. (2001). Die Geschichte der Krankenpflege (1679-2000): ein Quellenbuch. Frankfurt am Main: Mabuse Verlag.

Peeters, H. F. M. (1982). Historische fasen in aard en behandeling van geestesziekten. In J. M. W. Binneveld, C. Brinkgreve, A. J. Lameijn, H. F. M. Peeters, P. Vandermeersch, C. P. de Vos \& J. Vijselaar (eds.), Een psychiatrisch verleden: uit de geschiedenis van de psychiatrie. Baarn: Amboboeken.

Peeters, H. F. M., \& Vos, C. P. de (1982). Een historische analyse van een provinciaal psychiatrisch centrum over de periode 1885-1977. In J. M. W. Binneveld, C. Brinkgreve, A. J. Lameijn, H. F. M. Peeters, P. Vandermeersch, C. P. de Vos \& J. Vijselaar (eds.), Een psychiatrisch verleden: uit de geschiedenis van de psychiatrie. Baarn: Amboboeken.

Peplau, H. E. (1982). Historical development of psychiatric nursing: a preliminary statement of some facts and trends. In S. A. Smoyak \& S. Rouslin (eds.), A collection of classics in psychiatric nursing literature (pp. 10-46). Thorofare, N.J.: Charles B. Slack.

Peplau, H. E. (1989). Future directions in psychiatric nursing from the perspective of history. Journal of Psychosocial Nursing, 27, 18-28.

Peters, A., Thiesen, J., Verburg, H., Schene, A., \& Schrijvers, G. (2007). Zorgprogrammering in de GGZsector: de stand van zaken in 2006. Maandblad Geestelijke Volksgezondheid, 62, 500-511.

Philips, J. F. R. (1960). 50 Jaar Limburgse Groene Kruis: 50 jaar sociale gezondheidszorg in Limburg. Sittard: R.K. Vereniging "Het Limburgse Groene Kruis".

Piebenga, P. J. (1934). Op welke wijze kunnen de Kruisvereenigingen meewerken bij de voor- en nazorg van geesteszieken: welke eischen moeten daartoe aan de wijkzusters worden gesteld. Het Groene en Witte Kruis, 30, 172-187.

Porter, R. (2002). Madness: a brief history. New York: Oxford University Press.

Querido, A. (1933). Het Zeeburgerdorp: een sociaalpsychiatrische studie. Leiden; Amsterdam: Stenfert Kroese.

Querido, A. (1980). Doorgaand verkeer: autobiografische fragmenten. Lochem; Poperinge: De Tijdstroom.

Raecke. (1921). Moderne Irrenfürsorge und soziale Psychiatrie. Westdeutsche Ärzte-Zeitung, 12, 48.

Rähmi, L. (1918). Die Dauer der Anstaltsbehandlung der Schizophrenen [DI. 1]. PsychiatrischNeurologische Wochenschrift, 45/46, 283-291.

Rähmi, L. (1919). Die Dauer der Anstaltsbehandlung der Schizophrenen [DI. 2]. PsychiatrischNeurologische Wochenschrift, 47/48, 295-300.

Roberts, M. M. (1954). American nursing: history and interpretation. New York: Macmillan.

Roemer, H. (1920-1921). Die sozialen Aufgaben des Irrenarztes in der Gegenwart. PsychiatrischNeurologische Wochenschrift, 45/46, 343-351.

Romme, M. A. J. (ed.) (1978). Voorzieningen in de Geestelijke Gezondheidszorg: een gids voor consument en hulpverlener. Alphen aan den Rijn; Brussel: Samson. 
Scheer, W. M. van der (1930). Een blik in het arbeidsveld van den psychiater: klinische en sociale psychiatrie. Groningen [etc.]: Wolters.

Scheer, W. M. van der (1933). Nieuwere inzichten in de behandeling van geesteszieken: arbeidstherapie, actievere therapie volgens $\mathrm{Dr}$. H. Simon, de verpleging van onrustige krankzinnigen in geheel nieuwe banen. Groningen [etc.]: Wolters.

Scheer, W. van der (1934). Vraagstukken der sociale psychiatrie en der geestelijke volksgezondheid. Tijdschrift voor Sociale Geneeskunde(Febr.), 3-12, 35-19.

Scheffer, J. C. T. (1906). Voorlezingen over zenuwzieken en krankzinnigen en hunne verpleging: lessen gegeven aan de leerlingverpleegsters van de krankzinnigengestichten te Utrecht en te Endegeest en van het Sanatorium Rhijngeest te Oegstgeest. Haarlem: Bohn.

Schepper, R. M. de (1991). De Pameijer Stichting (1926-1991): een geschiedenis van de sociale psychiatrie en verstandelijk-gehandicaptenzorg te Rotterdam. Rotterdam: Pameijer Stichting.

Schim van der Loeff, H. J., \& Barnhoorn, J. A. J. (1932). Zielszieken en hunne verpleging (2e herz. ed.). Roermond-Maeseyck: Romen.

Schmiedebach, H., \& Priebe, S. (2004). Social psychiatry in Germany in the twentieth century: ideas and models. Medical History, 48, 449-472.

Schnabel, P. (1998). Dutch psychiatry after World War II: an overview. In M. Gijswijt-Hofstra \& R. S. Porter (eds.), Cultures of psychiatry and mental health care in postwar Britain and the Netherlands (pp. 29-42). Amsterdam [etc.]: Rodopi.

Schnitzler, J. G. (1915). Krankzinnigen en hun verpleging: een leidraad voor krankzinnigenverpleegsters (2e ed.). Amsterdam: De Bussy.

Schnitzler, J. G. (1926). Krankzinnigen en hun verpleging: een leidraad voor verplegenden in krankzinnigengestichten (3e ed.). Amsterdam: De Bussy.

Scholte, M., \& Brink, C. (2008). Transparant aanbod Sociaal Psychiatrisch Verpleegkundigen in de eerste lijn: modulen als bouwstenen voor de hulpverlening. Utrecht: Movisie.

Schout, G. (1998). Tussen bondgenootschap en 'deskundologie': verkenning van uitgangspunten voor methodiekontwikkeling in de (sociaal) psychiatrische verpleegkunde. Maandblad Geestelijke Volksgezondheid, 53, 1222-1234.

Schuurman, K. (1977). De ontwikkeling en de invloed van het beroep van psychiatrisch-sociaal werker, 1928-1965. Doctoraalscriptie Universiteit van Amsterdam, Amsterdam.

Schweighofer, J. (1926). Die Familie 135: eine sozialpsychiatrische Untersuchung. Zeitschrift für die Gesamte Neurologie und Psychiatrie, 623-654.

Shorter, E. (1997). A history of psychiatry: from the era of the asylum to the age of Prozac. New York [etc.]: Wiley.

Simon, H. (1929). Aktivere Krankenbehandlung in der Irrenanstalt. Berlin [etc.]: Walter de Gruyter.

Sociaalpsychiatrische dienst te weinig bekend: interview met zuster N. van der Hek (1962). Katholieke GezondheidsZorg(3), 98-99.

Sociaal Cultureel Planbureau (1998). Sociaal cultureel rapport 1998. Den Haag: SCP.

Sociaal Psychiatrische Dienst (1972). Taak en plaats van de maatschappelijk werkende bij de SPD. [S.I.]: SPD.

Sorel, F. M. (1982). De zorg nagelaten. Maandblad Geestelijke Volksgezondheid, 37, 1295-1305.

Southard, E. (1917). Alienists and psychiatrists: notes on divisions and nomenclature of mental hygiene. Mental Hygiene, 1, 567-571.

Southard, E. (1918). Mental hygiene and social work: notes on a course in social psychiatry for social workers. Mental Hygiene, 2, 388-406.

Spaulding, E. (1918). The training school of psychiatric social work at Smith College. Part 3: The course in social psychiatry. Mental Hygiene, 2, 586-589.

Stevens, F., \& Philipsen, H. (2003). Professionalisering van beroepen in de gezondheidszorg. In C. W. Aakster \& J. W. Groothoff (eds.), Medische sociologie: sociologische perspectieven op ziekte en zorg (5e geh. herz. ed.). Groningen; Houten: Wolters-Noordhoff.

Szasz, T. (1961). The myth of mental illness: foundations of a personal conduct. New York: Harper \& Row. 
Trimbos, C. J. B. J. (1955). De ontwikkeling der voor- en nazorgdiensten in het kader der geestelijke volksgezondheid. Maandblad Geestelijke Volksgezondheid, 10, 53-62.

Trimbos, C. J. B. J. (1959). De geestelijke gezondheidszorg in Nederland. Utrecht: Het Spectrum.

Trimbos, C. J. B. J. (1970). Perspektieven en wensen in de sociale psychiatrie. Maandblad Geestelijke Volksgezondheid, 25, 248-262.

Veeger, L. (1933). Geestelijke gezondheidszorg en de wijkverpleegster-huisbezoekster. Katholieke Gezondheidszorg, 4, 158-161.

Venneman, B. (2005). SPV op koers: prelude op de toekomst. Sociale Psychiatrie, 24(76), 23-31.

Venneman, B., \& Padt, I. van der (2001). Sociale psychiatrie als referentiekader voor de sociaalpsychiatrische verpleegkunde. Sociale Psychiatrie, 20(61), 7-17.

Venneman, B., \& Verberk, F. (2008). De sociaalpsychiatrisch verpleegkundige in de eerstelijns GGZ. Sociale Psychiatrie, 27(87), 7-14.

Verhaak, P. F. M., Zantinge, E. M., Vonk, E., Voordouw, I., \& Veen, C. van der (2005). GGZ-consultaties aan de eerstelijnszorg (registratie 2000-2004). Utrecht: NIVEL.

Vesseur, J. (1997). Activiteiten van de verpleegkundige in de psychiatrisch-intensieve thuiszorg: een evaluatieonderzoek naar de PIT-projecten Maastricht en Sittard. Maastricht: Wetenschapswinkel Universiteit Maastricht.

Vijselaar, J. (1980). De zedenkundige behandeling en de afschaffing van de lijfsdwang in het gesticht Meerenberg. In J. M. W. Binneveld, C. Brinkgreve, A. J. Lameijn, H. F. M. Peeters, P. Vandermeersch, C. P. de Vos \& J. Vijselaar (eds.), Een psychiatrisch verleden: uit de geschiedenis van de psychiatrie. Baarn: Amboboeken.

Visiecommissie Psychiatrisch Centrum St. Bavo (1973). De chronische patiënt: tweede rapport van de visiecommissie. Noordwijkerhout: Psychiatrisch Centrum St. Bavo.

Waaldijk, B. (1996). Het Amerika der vrouw: sekse en geschiedenis van maatschappelijk werk in Nederland en de Verenigde Staten. Groningen: Wolters-Noordhoff.

Walgrove, N. J. (1986). Mental health after care: where is nursing? Nursing Clinics of North America, 21, 473-481.

Walk, A. (1961). The history of mental nursing. Journal of Mental Science, 107(January), 1-17.

Weisbrod-Frey, H. (2001). Die Krankenpflegeausbildung im zeitlichen Überblick. In H. Steppe (ed.), Krankenpflege im Nazionalsozialismus. Frankfurt am Main: Mabuse Verlag.

Weisglas, M. (1981). De overgang van oppassers en oppasseressen naar verplegers en verpleegsters in de krankzinnigengestichten, 1880-1921: onderdeel van de hervorming van het Nederlandse krankzinnigenwezen. Doctoraalscriptie Universiteit van Amsterdam, Amsterdam.

Wennink, J. H. (1998). De ongelukkige relatie tussen maatschappelijke en geestelijke gezondheidszorg: een bezinning op 25 jaar (sociale) psychiatrie. Maarssen: Elsevier; De Tijdstroom.

Werkgroep Eindpunt Opleiding SPV (1981). De SPV tussen opleiding en werkveld. Utrecht: Nederlandse Vereniging voor Ambulante Geestelijke Gezondheidszorg.

Westhoff, H. (1996). Geestelijke bevrijders: Nederlandse katholieken en hun beweging voor geestelijke gezondheidszorg in de twintigste eeuw. Nijmegen: Valkhof Pers.

Wiegman, N. (1998). De verpleegster zij in de eerste plaats vrouw van karakter: ziekenverpleging als vrouwenzaak (1898-1998). In R. van Daalen \& M. Gijswijt-Hofstra (eds.), Gezond en wel: vrouwen in de zorg voor gezondheid in de twintigste eeuw. Amsterdam: Amsterdam University Press.

Wilde, G. de (ed.) (2002). Erbij horen: advies task force vermaatschappelijking geestelijke gezondheidszorg. Utrecht: Trimbos-instituut.

Willem Arntsz Stichting (1996). Jaarverslag 1959. In J. Dankers \& J. van der Linden (eds.), Van regenten en patiënten: de geschiedenis van de Willem Arntsz Stichting: Huis en Hoeve, Van der Hoeven Kliniek en Dennendal. Amsterdam; Meppel: Boom.

Willemsen, C. (2001). De belofte van het hiernamaals: zeventig jaar ambulante geestelijke gezondheidszorg in het gewest Breda, 1929-1999. Nijmegen: SUN.

Wolf, J., \& Hoof, F. van (1995). De waarde van het beroep voor de GGZ: een profiel van de beroepsgroep sociaalpsychiatrisch verpleegkundigen. Sociale Psychiatrie, 14(42), 27-33. 
Wunderink, L. (2005). Zorg met kleefkracht. Sociale Psychiatrie, 24(75), 15-23.

Zuithoff, D. (1959). Samenwerking psychiatrische inrichtingen sociaalpsychiatrische diensten. Maandblad voor de Geestelijke Gezondheidszorg, 14, 331-340. 


\section{Summary}

\section{Background}

On August 1, 2006, the Dutch Association of Social Psychiatric Nurses (NVSPV), with some 2,000 members, joins the professional foundation Nurses and Care Givers in the Netherlands (V\&VN). The NVSPV, founded in 1979, is no longer an independent foundation but part of an umbrella organisation under the name of V\&VN Department of Social Psychiatric Nurses (V\&VN-SPV). The magazine Social Psychiatry still exists. In 2003, a register is set up in which social psychiatric nurses can register. ${ }^{515}$

As of December 2006, in the V\&VN, 33 professional foundations are grouped together, boosting membership to around 20,000 . On one side the organization the V \& VN is the umbrella of professions while on the other side it is viewed as representative of the content and in more general terms, the development of the nursing and caring professions. The umbrella focuses [only] indirectly on working conditions. The unions are responsible for taking care of these interests. ${ }^{516}$

Aside from the new professional foundation and various unions, another professional foundation exists: $\mathrm{Nu}$ '91. This foundation focuses on the professional content as well as working conditions and has 20,000 members, including nurses and nursing assistants. ${ }^{517}$ The professional foundation Sting, exclusively for nursing assistants, lists slightly less than 3,000 members. ${ }^{518}$

Approximately 12 percent of the total 400,000 nurses and auxiliary nurses (hereinafter referred to as nursing assistants) in the Netherlands are registered members of a professional foundation. ${ }^{519}$

The 2006 merger appears to have been a significant episode in the development process of nursing and care giving in the Netherlands. The organizations involved in the merger agree that their shared interests and knowledge are enough to group into one organization. Obviously they find that there is an area of nursing and caring in which two professional groups can be active: the nurses and the nursing assistants.

From these two groups, the nurses have achieved a kind of social recognition by becoming officially listed in the BIG register. The Individual Health Care Professions Act (BIG) outlines the qualifications and competences, which permits one to prac-

\footnotetext{
${ }^{515}$ www.venvn.nl 30-10-2006

${ }^{516}$ www.venvn.nl 10-12-2008

${ }^{517}$ Communication Administrative Office Nu'91 01-12-2008

${ }^{518}$ www.levv.nl 30-10-2006

${ }^{519}$ Ibidem
} 
tice a profession in the individual healthcare field. Everyone who satisfies the necessary qualifications and competences criteria are permitted to register and can hold the title of nurse, which is protected by law. ${ }^{520}$ Although the title 'nursing assistant' is not a protected title, recognized institutes have uniformed requirements concerning education and the requisite practical experience.

The nursing and nursing assistant domain is known for its immense diversity. There are professionals who work in different environments that vary from particularly medical, cure-oriented departments of hospitals to care-oriented organizations such as home care or nursing homes. The work tasks vary from basic caring activities to highly technical cure.

There is a varying degree of independency in the role and responsibility towards the demanders of cure and care. Nurses and nursing assistants that work in periphery health care, i.e. home care nurses and family aides, are less an extension of a doctor than the nurses that work at the intensive care department of a university hospital. $^{521}$

The variation also exists in the content and the level of the educational backgrounds. In the Dutch healthcare system, employed professionals are educated at MBO (Secondary School), HBO (Tertiary Education) or University levels. Occupational titles vary from family aides, nursing assistants, specialist nurse to nurse specialist and nurse practitioner. There is a broad range of continued educational opportunities on offer.

A final point in which the diversity can be illustrated is the number of nurses and nursing assistants who became part of an organization: V\&VN-SPV in 2006 with 2,070 members, meaning that 80 percent of the group is organized in comparison with V\&VN GGZ psychiatric nurses who have 236 members from an estimated population of 12,000 psychiatric nurses, just below two percent. ${ }^{522}$

\section{Social psychiatric nurses}

The social psychiatric nurses are, when compared with psychiatric nurses, not only better organized, but they are also relatively better educated. According to a survey conducted in 2006, 70 percent of the V\&VN-SPV members have a HBO level of education (not specified) and 30 percent hold a diploma from a continuing education programme. The percentage rate between men and women is $42 \mathrm{vs.} 58$. Ten per-

\footnotetext{
${ }^{520}$ www.ribiz.nl 01-09-2009. 256.435 nurses are registred

${ }^{521}$ Boom, H. van der, Philipsen, H., \& Stevens, F. (2004). Een schets van de professionalisering van de wijkverpleging in Nederland in de laatste vijftig jaar (1950-2004). Gewina, 27, 100-119, 103.

${ }^{522}$ More recent information is not available. V\&VN does not register specialism.
} 
cent work primarily with younger people, 67 percent with adults including the elderly and thirteen percent work with other patient types (non-specific). ${ }^{523}$

Social psychiatric nurses, compared with psychiatric nurses, are a highly educated group of professionals. This is generated by the fact that the group with a Community Health Care/Mental Health Care (MGZ/GGZ) educational background has his own specialised course at the HBO level, which requires a basic nursing diploma. Psychiatric nurses do not hold such a distinction. They are able to start with a basic diploma be it a MBO or a HBO level. ${ }^{524}$

The level of education and work characteristics are typical for the social psychiatric nurses, probably more so than the level of organisation. The majority works extramural, with a high level of independency, under the supervision of psychiatrists. The social psychiatric nurse, who is employed at a family physician practice, does so under the supervision of these physicians.

Both the employment field and the employment background can be noted as the somewhat intangible term 'social psychiatry'. However, there is an obvious domain within healthcare, more specifically, mental health care, in which a professional group is active: the social psychiatric nurses.

\section{Research questions}

Little research has been carried out on the development of social psychiatric nursing. The goal of this study is to investigate and report on the origin and the development of social psychiatric nursing in the Netherlands, from its inception in the 1920s until about 1995. This is based on three questions:

- What is the origin of the specific domain "social psychiatry" within healthcare?

- How did in this domain develop a specific professional nursing group?

- What are the future expectations? Can it be expected that, with the changes that have already been partially carried out and will still be realized, social psychiatric nursing will remain a specific profession?

This thesis is mainly a study of the first two questions. The third question will be discussed at the end in a reflection on the results of this thesis.

After the build up of the thesis a theoretical framework will be presented that will be the starting point for the analysis afterwards.

\footnotetext{
${ }^{523}$ Ledenraadpleging V\&VN-SPV 2006. Rapport 29-11-2006, Noordam \& De Vries, 11-12. Seventy percent is on the low side. For a part this can be explained by the fact that nurses with continued and a higher education do not consider themselves as $\mathrm{HBO}$ educated. Another explanation might be that up until 1996 the existing dispensation ruling of the Health Care Inspectorate made it possible for non$\mathrm{HBO}$ educated nurses to work as social psychiatric nurses.

${ }^{524}$ Psychiatric nurses are referred here as nurses without a MGZ/GGZ education who are actively working in psychiatry e.g. psychiatric hospitals.
} 


\section{Structure and division of this thesis}

Between the first introductory chapter and the final chapter, this thesis is made up of seven chapters, which focus in a chronological order, on the first two research questions.

In Chapter 2, a description of the origins of the social psychiatry movement, based on literature research, is provided. Since this not possible without an understanding of psychiatry within the institutions, we begin with an explanation. The chapter covers the period between the start of the twentieth century, when the term social psychiatry is first introduced, up until the Second World War. The description provides an outline of developments in Germany and the USA, followed by the Netherlands. The developments in the Netherlands are strongly influenced by those in Germany and the USA. It clearly shows the development of a specific domain of social psychiatry other than clinical psychiatry. Fast and industrializing societies, believe it to be important that once a patient is discharged, he should remain under supervision in his living environment and that activities are initiated, which result in the prevention of new disorders and/or (re)admission to an institute. The psychiatrists take the initiatives and try to increase aftercare for patients discharged from an institute by influencing public opinion and by the use of assistants. Around 1930 onwards in the Netherlands, nurses are working extramural psychiatric consulting hours and executing house calls, initiated by the psychiatric institutes and provincial and city organizations. This is the origin of a specific and recognized healthcare domain, but a specific social psychiatric profession, medical as well as nursing, does not exist. There is little or no description of the operational work carried out in this domain.

In Chapter 3 a comparison is made between the USA and the Netherlands covering the same period as in Chapter 1 . Although in both countries a social psychiatric domain develops along more or less similar lines, it leads to different developments in the related professions. Since the start of the century in the USA, social workers have been involved with the extramural care for psychiatric patients. This has been carried out by nurses in the Netherlands, since about 1920. A description of these two processes helps to answer the second research question, reading as follows: How, given a certain domain in healthcare, does a profession develop? Obviously a social necessity for aftercare or preventative care can lead to the origin of psychiatric social work as well as social psychiatric nursing. As background information a description of the development of psychiatric nursing in general, which means its development within psychiatric institutions, will be given.

In Chapter 4 the information contained in Chapters 2 and 3 will be analyzed. The developments in the USA, Germany and The Netherlands are summarized and compared. This comparison is useful for answering the first research question, stating: What is the origin of the specific domain "social psychiatry" within health care? 
Basically this comparison is also useful for initiating the second research question: How did in this domain develop a specific professional nursing group? This is carried out in terms taken from the theoretical framework (Chapter 1 ), more specifically the Benson related ideas about inter- and intra-professional coherence. Chapter 4 also determines the manner in which in the succeeding chapters the second question will be answered in greater detail.

Chapter 5, also based on literature study, provides information concerning the continued development within The Netherlands, from the Second World War until about 1985. Around that time, the expansion of extramural mental health care in a system of Regional Institutes of Outpatient Mental Health Care (RIAGG's), including fiscal support from the Exceptional Medical Expenses Act (AWBZ), concludes. The social psychiatric domain becomes independent. Social psychiatric nurses maintain a strong position within this field. The number of nurses increases, the educational requirements escalate and the work takes on a professional character. Not only does the domain become more independent, but also more complex. A shift occurs from the care of former institutional patients towards care for clients with less severe psychopathology that have never been institutionalized. Social psychiatrists and social psychiatric nurses are not the only professionals. In order to fully understand, a description of the developments in psychiatry in general, which occur in the 1970 s and are very substantial, is provided.

Chapters 6 and 7 contain a more detailed underpinning of the Dutch situation, as given in Chapter 5. Chapter 6 outlines the development of social psychiatry in the Province of Limburg, how social psychiatric nurses elevate and define their position. This is based on information extracted from annual reports and files of the former Roman Catholic Association The Limburg Green Cross (association for home care) and the former Venray Psychiatric Hospitals - St. Servatius and St. Anna. A sample of 382 status reports of patients who left the institutes between 1938 and 1973, were extracted from the archives. Information is gathered from the status reports about how many and what kind of contacts are established with which persons and organizations outside of the institute. Around 1960 a crucial shift occurs. Until that time there is little systematic contact between the institutes and especially with patient family members. Following this period, in 80 to 100 percent of all cases, contact continues between the institutes and social psychiatric care. Contact with patient family members strongly declines.

Chapter 7 is based on interviews with retired social psychiatric nurses together with information collected from earlier studies. The focus is on questions of how nurses experience the development of their profession and how they describe the relationship with other professional groups within the social psychiatric field. An important question is: What activities and competences contribute towards the professionalization of social psychiatric nurses within the nursing profession and within the domain of social psychiatry? Information in this chapter deals with the period 
beginning in the first half of the 1950s until the mid-1980s. The group, from which the information is collected, can be divided into three sub-groups. The first group has been active since the late 1940s, early 1950s. None of them has a MGZ/GGZ educational background and a few have experience with the creation of the Riagg. The second group is made up of nurses who have been active since the early 1960s. None of them has an MGZ/GGZ educational background and they all have experience with the creation of the RIAGG. The third group represents the generation born around 1950. Their common denominator is that they all have an MGZ/GGZ education, the first ones in 1974, and the latter in 1980. Some of them have experience with the changeover to RIAGG. The creation of RIAGG is, in many ways, a landmark in the development of social psychiatric nursing.

Chapter 8 provides a general outline of the developments within the domain of mental health care and Social Psychiatric Nursing from 1985 until around 2005 with some exeptions taken from 2008 . The borders of the different domains intra- and extramural mental health care turn out to be less clear as a result of societal developments. The role of the government is very influential. At the turn of the twenty first century, the government announces a new strategy policy that, if carried out, will have profound consequences for the sectoral structure of second-line mental health care. This chapter also confirms that the developments in the social psychiatric nursing profession are strongly influenced by external developments and circumstances. A good example would be the change in the education system, which as a matter of consequence, resulted in the discontinuance of the MGZ/GGZ. New is that nurses, at least an important group, take a definite position in the debate and decide to work with complex accessible, workable patients and for what is known as "social psychiatric course of thought".

The final chapter reflects on the findings of this thesis and, based on recent and expected developments, a preview of future social psychiatric nursing. The final chapter is included in this summary. This is followed with some comments and final remarks.

The theoretical framework will be presented in the following paragraph and will be the starting point for the analysis of this thesis.

\section{A vision at domains, professions and professionalization}

Healthcare professionals have health problems as domain, this is their focal point. They are able to focus on problems because they have specific knowledge and capability that others either do not have or do not have enough of.

Health problems vary in complexity. Problems with low complexity i.e. help in household chores can be managed by splitting the tasks into relatively simple tasks that can be carried out by workers with little education. This is work division without specialization and the organization can be summarized as bureaucratization. 
More complex problems such as extramural care for psychiatric patients cannot be solved by this type of work organization. There is a need for knowledge, evaluation and capacity of professionals who have acquired this from extended education, internships and work experience. In this kind of work organization, one can speak of professionalization and professions.

Professionalization has been investigated in a variety of ways over time.

In the functional approach, the question is asked "Why does the profession exist?" Central here is the idea that professionals acquire their status from their societal duties. They gain these duties as a result of the increasing modernization of societal complexities and the increasing complexity of the problems. Specialized knowledge of the professional is necessary to solve the problems. In other words, there is a need for specialists whose work it is to solve those problems ${ }^{525}$. "Ideology of Service" or "doing good" is the heart of professionalism, work in which the professional's interest does not factor. The relationship between a doctor and a patient is an example. ${ }^{526}$ The doctor is a professional who, affective neutral, functional specific and universal, uses his knowledge to help people. The patient is the nonprofessional who trusts the doctor. ${ }^{527}$

The functional approach does not ask how do professions exist, but how they can be characterized, how can they be distinguished from non-professions. The characteristics of professions are: having scientifically based knowledge, being active for the general cause that cannot or may be done by others; having autonomy over the practice of the profession. The professionalization process has different phases: attempt to gain juridical acknowledgement, establishing of own (academic) educations and exams; establishing an ethical code and the development towards internationalization. ${ }^{528}$ These phases, with no agreement in the literature about the criterion for sequence, suggest starting and final points in the development process from occupation to profession. ${ }^{529}$

The power approach or "strategy of occupational control" concentrates on the acquisition of power and the way a profession acquires and utilizes that power. Freidson refers to the medical profession as the profession that succeeded in this. The profession has disposed a lot of routine work to e.g. nurses, received judicial support for the power status towards defining and approaching problems, created a

\footnotetext{
${ }^{525}$ Houten, van D. (2006). Professionalisering en arbeidsdeling. Sociale Interventie, 2, 17-25, 18.

${ }^{526}$ Ibidem, 18.

${ }^{527}$ Stevens, F., \& Philipsen, H. (2003). Professionalisering van beroepen in de gezondheidszorg. In C.W. Aakster, \& J.W. Groothoff (eds.), Medische Sociologie: sociologische perspectieven op ziekte en zorg. Groningen/Houten: wolters Noordhoff, 86.

${ }^{528}$ Ibidem, 86

${ }^{529}$ Boom, van der H. (2008). Home nursing in Europe: patterns of professionalisation and institutionalisation of home care and family care to elderly people in Denmark, France, the Netherlands and Germany. Amsterdam: Aksant, 43.
} 
market for their services and a monopoly over education. ${ }^{530}$ Illich views the power of the medical profession among other things in the dependency of patients that are saved by the experts. ${ }^{531}$

These approaches offer potential for a good study of professions.

Abott's comments concerning professionalization approaches are that the assumptions, which provide the basis, be open to criticism. The assumptions are: professions develop along a given pattern; the development of a profession occurs independently from other, related professions; the structure and cultural claims of a profession are more important than the actual work; professions are homogeneous, internal small differentiated units and finally, the professionalization process does not change over time ${ }^{532}$.

According to Abott too much emphasis is placed on "empirical facts and structural characteristics (in Abbott's terms: 'external appearances') while the processes and interactions preceding these outcomes (Abbott: 'intrinsic qualities of professions') are far more important to professions". ${ }^{533}$ To obtain a good overview of the pro-cesses and interactions, Abbott solicits using the content of the work, visible in the diagnostics, decision-making and interventions, as a starting point for the research of professions. ${ }^{534}$

Profession are widely described by Abott as "exclusive occupational groups applying somewhat abstract knowledge to particular cases". ${ }^{535}$ "Although its precise meaning is not narrowed down, people generally understand what is meant by the term 'profession', and therefore need no further specification of what a profession 'is' or represents. Instead, it is more useful to focus on their roles and functions in society". ${ }^{536}$

Professions claim control or jurisdiction about the way in which they work, and the manner in which they define their problems and tasks. Accomplishment of the work and of the interventions greatly defines the power of the claim - successful professionalization and eventually, the future existence of the profession. Support with an (abstract) knowledge system is important. An (abstract) knowledge system can pose questions, define tasks and redefine and protect against an eventual take over by other professions.

\footnotetext{
${ }^{530}$ Stevens F. \& Philipsen, H. (2003). Professionalisering van beroepen in de gezondheidszorg, 89.

531 Illich, I.D., Zola, I.K. \& MacNight, J. (1977). Disabling professions. London: Boyars, 29.

${ }^{532}$ Abbott, A. (1988). The system of professions: an essay on the division of expert labor.Chicago: The University of Chicago Press, 17.

${ }^{533}$ Boom, van der, H. (2008). Home nursing in Europe: patterns of professionalisation and institutionalisation of home care and family care to elderly people in Denmark, France, the Netherlands and Germany, 47.

${ }^{534}$ Abbott, A. (1988). The system of professions: an essay on the division of expert labor, 40.

535 Ibidem, 318.

${ }^{536}$ Boom, van der, H. (2008). Home nursing in Europe: patterns of professionalisation and institutionalisation of home care and family care to elderly people in Denmark, France, the Netherlands and Germany, 46.
} 
In reality of the current complex healthcare, professional claims are not absolute and are not exclusively defined by a particular professional group. There are not many complex problems that are the domain of just one profession. ${ }^{537}$ In resolving the disruptive behaviour of a psychotic person in a neighbourhood not only the problem definition of the social psychiatric nurse, but also of the local police officer is relevant. Cooperation of working together and adjustment of activities is inevitable and as a matter of consequence, the borders between professions are accessible. The analysis of the development of related groups is not complete without studying the border area and the inclusion of inter-professional competition.

Aside from the fact that professions influence one another, they also form part of the societal field of power. ${ }^{538}$ They also seek acknowledgement of their profession and the scientific basis of it. Developments in that field influence the kind and content of the activities of the professionals. One can think of laws and regulations and developments such as the advance of customer interest groups.

In summary, three perspectives can be distinguished that lead to a sound study of professions, in this case, social psychiatric nursing: the intra-professional, the inter-professional and the meta-professional perspective.

A more concrete study of professions can be achieved by using the ideas of Benson. ${ }^{539}$ Although Benson focuses on the interaction between organizations, his approach provides useful starting points for studying professions.

By analyzing the relations between professions the dimensions domain consensus, ideological consensus, positive evaluation and work coordination can be divided. Domain consensus is the way in which there is agreement between professions about each other's tasks and work field. Ideological consensus is the manner in which professions agree about the vision that forms the basis of the work. Positive evaluation is the manner in which there is positive judgment about each other's work. The degree in which the activities of both parties are matched to one another is called work coordination.

An example to better understand this is: Nursing assistants and nurses are involved with caring for patients who as a result of motor functioning defects following an accident, can no longer take care of themselves. The nursing assistants specifically focus on providing care in the narrow sense of the word e.g. personal hygiene. Nurses focus on helping the patient to care for him/herself, and to regain their independence as quickly as possible. This example reveals consensus in the domain: care for an individual with motor functional defects. There is no consensus concerning the basic vision from which the work is executed; there is no ideological

\footnotetext{
${ }^{537}$ Boom, H. van der, Philipsen, H., \& Stevens, F. Een schets van de professionalisering van de wijkverpleging in Nederland in de laatste vijftig jaar (1950-2004), 116.

${ }_{538}$ Abbott, A. (1988). The system of professions: an essay on the division of expert labor, 33.

539 Benson, J.K. (1975). The interorganizational network as a political economy. Administrative Science Quarterly, 20, 229-249, 235-236.
} 
consensus. One group provides care while the other group provides rehabilitation. Predictably both groups may be unimpressed with each other's work. It is not inconceivable to think that these activities are not well coordinated. In other words: the evaluation of each other's work rates is low and the work coordination is insufficient.

The four dimensions, as displayed in the example, maintain a certain kind of relation. Relation means that changes in one dimension will lead to changes in other dimensions, that there is a balance in the relationship between professions. The balance must not be observed in a mechanical way in which a change that occurs in one dimension will automatically lead to changes in another dimension. What this means is that there is a tendency of co-variation of the four dimensions. ${ }^{540}$ If two professions disagree about one another's domain, then there will be little work coordination. Placed in a sequence of high to low, the four dimensions will move closer together. When dimensions score higher or lower on that sequence, one can refer to this as higher or lower inter-professional coherence.

The same idea can be used to measure intra-professional cohesion. If there is more agreement in a profession about the four dimensions, coherence will be higher. This is supposed to be a condition for professionalization.

The balance between the four dimensions is not an autonomous matter, but depends on societal forces. This means that the variation of balance is only possible within the limits created by actors in the societal field of power.

Also based on Benson's ideas - the intra-, inter- and meta-professional perspective can be useful in studying professions.

\section{The origins of the domain of social psychiatry until about 1940}

At the beginning of the twentieth century, the psychiatric domain in the USA, Germany and the Netherlands is mainly limited to institutes. There has been a sharp growth, from the 1850s on, in the number of institutes and the existing ones become larger and larger. On the one hand, the growth can be explained by the substantial raise in admissions, not only of psychiatric patients, but also groups of societal non-adaptive. On the other hand, the growth results from the fact that treatment of patients has little effect. Large groups of non-voluntary admissions fill the institutes with poor hygienic conditions where aggression, coercion and forcefulness are a part of daily life.

Two professions are active in this field for treating and caring for the patients. One group of doctors with or without a psychiatric education and the other group is the early formation of what we now call nurses: the lay attendants.

\footnotetext{
${ }^{540}$ Hermans, E. (2000). In het verkeerde bed: het zorgtraject van een cohort CVA-patiënten na ziekenhuisopname. PhD-thesis. Maastricht: Universiteit Maastricht, 117.
} 
The standing of these two groups is low and their fields of knowledge scarcely developed. The psychiatrists do little more than offer diagnosis and provide somatic care to the many physically ill. The uneducated and untrained attendants are basically concerned with maintaining basic hygiene and law and order. At the end of the century psychiatrists initiate nursing vocational education. The content is primarily physically oriented and focused on achieving information for psychiatric diagnoses.

At the beginning of the twentieth century psychiatry extends its domain outside the walls of the institutions. The explanation is a combination of different factors. The first is that industrialization, urbanization and migration, and societal dynamics lead to social disorder that requires intervention. The second holds to notions from sociology and psychology that say human behaviour is not only biologically determined, but also that environment may add to the existence and the maintenance of behaviour and behavioural problems. The latter factors are the less successful intramural psychiatry, the unmanageable situation within the institutions and the continued increase of costs. In short: there are reasons to alter attention and new possibilities to implement these changes.

Two new options occur in the field of psychiatry. The first option is to include the feasibility to prevent problems by paying attention to such items as child labour, prostitution, alcoholism and early intervention. In the mid-20s this becomes the field of the movement of psycho-hygiene. The other option is to solve existing problems: the unsuccessful treatment of larger groups in over-crowded institutions, the related costs and preparation for discharge. This becomes the field of social psychiatry. Aside from the movement of psycho-hygiene and social psychiatry, institutional psychiatry remains. A three-part division occurs in the world of mental health: the psychiatric institutes for intramural treatment, pre- and after- care for extramural treatment and the psycho-hygienic approach towards social problems.

From the beginning, two professional groups are active in the domain of social psychiatry in all three countries: in the USA these are psychiatrists and social workers, in Germany and the Netherlands these are psychiatrists and nurses.

From the end of the nineteenth century social workers (USA) play an active and recognized role in the care of psychiatric patients. From the beginning of the twentieth century doctors and psychiatrists use them to gain information concerning social factors for medical diagnosis and treatment. At the same time the influence of social workers leads to a more effective approach towards health problems.

At the beginning of the twentieth century, social workers develop their own education and from about 1910, they developed their own methodological approach. It is focussed on providing the patients with insights into their problems and/or to adapt to changes. This method allows them to gather information for the psychiatrists. In 1918, the social workers together with the psychiatrists develop a new education. This is a landmark in terms of the existence of a new, introductory, 
small specialism of psychiatric social work. The professional group quickly becomes more professionalized. Educative books are written, a professional foundation is established and college/university courses are developed.

As a result of the cooperation with the psychiatrists, social workers become less independent however they acquire the opportunity to develop their own practice the social case work. The psychiatric social workers, in close cooperation with the psychiatrists, assume a role that psychiatrists cannot because they are too few and do not have the proper education.

The social orientation starts to shift during the 20 s towards a more psychological, psycho-dynamic orientation. Therefore, the social psychiatric workers develop a greater distance during this time, from the more social psychiatric aftercare. They find other employment e.g. in child guidance clinics. With the continuation of professionalization, the group slightly separates from the original target group: the patients in the institutes and the ones who have left the institutes.

Psychiatrists from Germany and the Netherlands involve nurses in their social psychiatric activities.

The first development (1910) on extramural psychiatric care in Germany is brought to a halt by the First World War. After the war, aftercare is mainly organized by the institutions. This care is highly institutional replacing, structural and managing. Care is distributed by hospital trained nurses with very little education, not focussed on social psychiatric and societal care. They are strongly guided by the psychiatrists in terms of their ideas and method of working. The same can be said for the social workers working in the cities with only limited psychiatric education.

In the beginning, in the Netherlands, social psychiatry is developed from either city or personal initiatives, later by psychiatric institutes and different Cross Associations for home nursing. At first, psychiatrists also involve community nurses in their activities. These community nurses have a modest psychiatric education. Aside from assisting the psychiatrist, they also play a role in uncovering psychiatric problems at the early stages. Thus, in the beginning, social psychiatry focussed, or at least partly, on prevention.

From 1926 onwards, the institutes establish aftercare services, which are also known as "external services". These services are based on those established in Germany. A small number of psychiatrists and institute nurses establish a consultation bureau and execute a lot of house calls. The activities of the external services are mainly characterized as aftercare and can be observed as providing structure and organization to the patient by managing them. They are primarily focussed on offering advice in accordance to daily life of patients and others within their direct living environment and the management of it.

From 1934, when the Municipal Health Services (GG \& GD) located in the larger cities begin to focus on extramural care, little changes. Once again a great number 
of house calls are now conducted by a small number of nurses and a small number of psychiatrists. Precare becomes a new addition to their activities, however, the work is characteristic of social services targeted towards decreasing the number of persons admitted to institutes, or at least stabilizing the number of admissions. Structuring and managing also became important work issues.

Within the Dutch social psychiatry domain, two professional groups now exist: psychiatrists and nurses. The psychiatrists, who work mainly on a part-time basis, are employed at consultation bureaus, refer patients to other doctors and make relatively few house calls. The nurses, who work mainly on a full-time basis, assist during the consultation hours and make many house calls. Neither the psychiatrists nor the nurses have a social psychiatric education. Their performance is based on personal ideas and experience. Psychiatry has no knowledge of the social psychiatry specialism. The course "Aftercare for Nurses", established in 1937 and initiated by psychiatrists, is very practically orientated and focusses on non-psychiatric subjects. At the beginning of the 1940s, 49 persons have a diploma. The clinical orientation remains very strong.

Against the background of the previously described common societal and professional content issues and developments taking place in the USA, Germany and the Netherlands psychiatrists initiate care outside of the institutional walls. This is the beginning of a new, limited domain in healthcare, social psychiatry. It is, in other words a merger of meta- and inter-professional factors is the reason for the development of the new domain. The psychiatrists, insofar as they are educated as such, are biologically, organically oriented, have ideas and ideals, but they possess neither the knowledge nor the capacity, and are too few in number to realize these ideas and ideals. Others are needed to design the form and content of the activities. In the USA, these are social workers, in Germany and the Netherlands nurses are introduced to the new domain by the psychiatrists. The reason for these different choices are that although they share similarities, there are apparent differences between the USA, Germany and the Netherlands.

In American society societal problems are deemed more urgent than in Europe. More so than in Germany, while in the Netherlands, charity and not the government, play a greater role in resolving problems. In the USA the influence of psychology on psychiatry is greater than in Germany and the Netherlands. In general, American society tends to be more pragmatic and more problem-solving oriented. For this reason, psychiatry in the USA, at least the principal psychiatrists, are more dynamic than in Germany or the Netherlands. In the latter two countries psychiatry can be viewed as more descriptive and philosophical. American psychiatry not only recognizes the social environment as a source for the development of psychiatric problems, but also uses it to solve and prevent these problems. Therefore the American psychiatrists select social workers. They have already profiled themselves 
in the care of psychiatric patients. This plays a role in the selection of the psychiatrist. The social workers have the knowledge and capacity, which the psychiatrists do not.

German and Dutch psychiatrists, compared with their American colleagues, tend to be somewhat conservative. They think and operate from an individual, institutional, psychiatric perspective and are more focussed on adaptation than on change or on the very real inclusion of environmental factors in the treatment of patients. Nurses conform well to this orientation. Their thoughts and performance, much more so than the social workers, are determined by psychiatrists. They haven't yet developed their own knowledge domain. With regard to such professionalization issues as individual professional education, compared to social workers in the USA, they fall behind. In spite of this, the nurses immediately become the centre point of aftercare. They are responsible for the majority of the work. It is clear that within limits addressed by the psychiatrists, they have the opportunity to act in accordance to their personal ideas and to develop personal working methods. Initially this does not lead to a more explicit viewpoint of their work nor do they reflect on it.

\section{Further development of social psychiatry from about 1940 until around 1985}

The era between 1940 and 1985 roughly can be defined as a period of growth, heightened dynamics and complexity, not only for social psychiatry, but also the psychiatry of the institutes.

Institutional psychiatry slowly overcomes the effects of the Second World War. Still, treatment is rarely successful. There is a breakthrough generated by the introduction of psycho-pharmaceuticals in the 1950s. Patients become more accessible and the number of forced treatments and the length of these treatments decrease. Some institutes introduce new methods of treatment including individual psychotherapy and social therapy. This development proceeds slowly because there is a lack of well-educated personnel.

More substantial changes occur in the 1960s. The average stay for patients, also a result of the use of psycho-pharmaceuticals, decreases. With the introduction of the Exceptional Medical Expenses Act (AWBZ) in 1967, the costs of longer stays are covered. Financial assets grow and the shortage of personnel is halted. Another important factor is the rise of critical or anti-psychiatry, which occurs during the second-half of the 1960s. Sharp criticism is conveyed towards the medical orientation of psychiatry and the assumed inhuman conditions inside the institutes. A difference in ideas and the frequent rigid conflicts concerning the handling and treatment of patients become regular occurrences in the larger institutions. Patients should 
not be viewed as ill, but as individuals with problems that the onus for sol-ving these problems is largely the responsibility of the patient.

During the 1970s government influence of the institutes becomes more evident. The emphasis is on accessible and coherent intramural and extramural services and the strong development of extramural psychiatry. A start is made to decrease the number of psychiatric institutes. Around the same time - early 1970s the number of out-patient clinics within the institutes, increase. The out-patient clinics offer partial patient aftercare, and increasingly focus on the treatment of a similar group of adult patients who are from the departments of Adult Health Care of what since 1982 is known as the Regional Institute for Outpatient Mental Health Care (RIAGG). The RIAGG's house Child Guidance Clinics, Centres for Marriage and Family Problems and Social Psychiatric Services. The pre- and aftercare operational services are merged together in the services.

For pre- and aftercare, insofar as they are connected to the psychiatric institutes - early 1940s - a start is made to gain independence, something that finishes in the 1950s. Since institutes do not work for a specific healthcare region, patient accessibility is more difficult and the quality of care is often deemed insufficient. Cities and Provinces that become involved with aftercare are involved with the quality of care because quality influences the number and duration of stays inside the institutes. A merger of content and financial consideration results in the separation of 'external services' and the institutes. Institutional pre- and aftercare services, become a part of the provincial, regional and local co-operations and foundations. Existing aftercare services, psychiatric institutes, local psychiatrists, family physicians and rehabilitation boarding houses form an unmanageable patchwork of services. Institutes offer intramural treatment, the aftercare services offer extramural aftercare; local psychiatrists and family physicians offer extramural medical treatment. This complex system of institutes and persons is difficult to manage. Cooperation is mostly limited to free format agreements concerning admission and discharge procedures. This becomes more complex when the pressure on aftercare services increases as the number of institutional discharges grow as a result of using psycho-pharmaceuticals. Not seldom are patients discharged without first notifying aftercare services. Admissions, deemed necessary by these services, are not always realized.

In 1960 pre- and aftercare work is still carried out by psychiatrists and nurses. Even though the organisational division between institutes and aftercare is a fact, aftercare is administered and coordinated by the institute psychiatrists or psychiatrists who originated from the institutes. Nurses are mainly educated at the institutes and in the case that they finished their psychiatric aftercare training, very individual, managing and structurally focussed. Psychiatric aftercare is to a great degree an extension of institutional psychiatry. This only changes around 1970. 
Prior to this, four significant influencing factors can be defined. The first is the national financing for social psychiatric services (1961). This means that the federal government pays 40 percent of personnel costs. This new ruling results in a growth of services offered and any existing imbalance of assets between the different services partially disappears. Owing to an improved financial situation, services are able to focus on a new group of voluntary patients - people without a serious or urgent psychiatric problem - who benefit from help and guidance over a longer period of time. The second important factor is the arrival of psychologists. Important because the idea that not only psychopathology, but also life problems, can lead to serious dysfunctions and, as a consequence, require treatment. The previously mentioned financial prospects enhance the opportunity for the new professional group to exist. The third important fact is the open criticism or anti-psychiatry perception, which influences social psychiatry during the second-half of the 1960s. Attention is demanded on the influence of societal and interpersonal factors on the existence and maintenance of psychiatric problems and for a more active role of the patient to solve these problems. Responsibility and motivation of patients are key words that go together with insight and change-focussed treatment. In a short period of time these psycho-therapeutic treatment methods, in which psychologists are involved, become the main method of working. The old-style form of pre- and aftercare falls to the background without ever completely disappearing. The fourth factor is the financing of the extramural mental health by the AWBZ from 1971 onwards. The AWBZ makes it possible for the domain social psychiatry to grow. As a consequence, the number of psychiatrists, psychologists and nurses grows. The nurses remain the largest professional group. For this group the changing ideas about desirable treatment eventually have consequences in their daily work. The occurrence of changes also becomes clear in the development of nursing education in the 1960s.

The existing psychiatric aftercare training, offered to nurses from 1937 onwards is no longer considered a good basis for the nursing profession in extramural care. In 1961, 1964, and 1969, different committees present different proposals for new education. Throughout the development of these proposals, psychiatrists and psychiatric professional foundations play a significant role. The membership of a nurse in the committee 1961 and two nurses in 1969 indicates that nurses also receive recognition in the establishment of the new specialized education.

In 1971 the Catholic Social Academy De Aemstelhoorn in Amsterdam, is authorized to start with a new educational programme for social psychiatric nursing: Community Health Care, specialization Mental Health Care MGZ/GGZ.

In 1973, the diploma general nursing (diploma A), is no longer an entrance requirement and the diploma psychiatric nursing (diploma $B$ ) is deemed sufficient. Two years later the educational programme is offered at seven different locations throughout the country. Meanwhile in 1965, men are admitted to the education 
programme 'Community Nursing' and, as a result of this, are now permitted to take part in the psychiatric aftercare education. With the discontinuance of the Diploma of Community Nursing as an entrance requisite for the new education programme MGZ/GGZ, the number of men in extramural psychiatric nursing increases further. In 1995, from the approximate total of the 1,500 to 1,600 nurses, the proportion of women vs. men is 47-53.

In the first years of the new education programme, a search to define distinguished characteristics of social psychiatric nursing takes place and tension arises between the education and the work field. The search to define the individual character proves difficult. The clinical experience of the nurses is conceived as essential for their professional practise, but holds a number of stigmatic elements. The clinical experience separates the nurses from the social workers and provides the potential "to implement things in a different way". A reason not to overemphasize the nursing character of the education is that there is a strong link to what is called "the medical model and medical thinking". The development within psychiatry is to depart from that model and thinking. This can be seen as the influence of the social sciences related to the promotion of personal, social and cultural welfare (agogiek and andragogie) on the education. Nursing methodology is based on that because as they say, education focuses on guidance and support. In 1979, a social psychiatric nurse is described as "a worker in mental health care who tries to initiate an influencing process focussed on the entire context of the individual who requests care, more specifically, on the living environment." In education, the required attitude development for activity in the profession in the field of societal health care is the central point. Greater detail of what this attitude means is not described.

The difficult relation between the education and the work field, especially the desired autonomy by the schools is a theme that frequently reoccurs. It is, for instance, difficult to reach agreement about the conditions of a traineeship and related mentoring. The different work places have their own ideas about such conditions for nurses and some of the education training institutes accept these conditions. The difference concerning the conditions for nurses becomes clear in 1979. In the work field there are opinions to change the education so that nurses will focus on the initial aftercare of patients. The education establishment think that this group already has enough attention and does not implement the changes. Obviously there is a limit to the adaptability of the schools.

Aside from the professional education for social psychiatric nurses, around 1970, nurses become more interested in deeper, additional education. For example, education in the fields of group therapy, relation therapy and behaviour therapy starts slowly. In 1976, a publication, written by a nurse is published in which it is stipulated that social psychiatric nursing should focus on family treatment. For registration as a 
psychotherapist, on which a committee advises the government in 1981, nurses are excluded. An academic education is necessary to be registered.

The existence of a professional foundation in 1979 can be viewed as a significant moment in the professionalization process of social psychiatric nursing. In the beginning the foundation mainly tries to influence nursing working conditions. However, the attention quickly turns to professional content. An example is the discussion that takes place in the foundation about the development within the professional group. This demonstrates the worries about the inclination of nurses to develop in the direction of a therapist. Aftercare and what is referred to as the underprivileged is neglected. The schooling, as is stated, should focus more on curative activities for what is referred to as "hopeless cases".

\section{Social psychiatry in the province of Limburg until around 1975}

Social psychiatry exists in the Province of Limburg since the latter part of the 1930s, some fifteen to twenty years later than the first initiatives in the Netherlands. Developments are slow in the beginning. Especially the small number of patients, mostly children and adults without an institutional history, make use of the consultation hours. These consultation hours are offered by psychiatrists of the Venray institutes St. Servatius and St. Anna, with the assistance of a nurse. Incidentally, the nurse makes house calls. Aftercare in the literal term, does not yet exist.

With the appearance of the full-time nurse in 1940 growth begins. The nurse makes a great number of house calls. The calls are especially focussed on (ex)patients and therefore on the aftercare. Growth continues after the end of the war and is mainly conducted by the growing group of nurses. The number of psychiatrists remains low until late in the 1960s. Until that time, with one exception, they work on a part-time basis. Around 1960, there are six active aftercare nurses. Aside from making house calls, they participate in monthly meetings held at the institutes together with the psychiatrists. Testing probationary release, discharge or (re)-admission of patients is discussed during these meetings. These meetings are no guarantee for good cooperation. Releases are regularly organized without aftercare service and admissions, although necessary according to the service, fail to be carried out.

As of 1958 the number of contacts between the institutes and aftercare increases. The biggest increase (100 percent) in 1963, takes place after the introduction of the provincial aftercare psychiatrist. The contacts, which are mainly by correspondence, take place when a probationary release or discharge is announced. The number of contacts between the institute psychiatrists and patient family members decreases during the same period.

The position of the institute psychiatrist remains important. Real psychiatry is carried out in the institutes. For a long time social psychiatry is an extramural exten- 
sion of the institutional psychiatry. Social psychiatry is highly based on experience and knowledge and is a kind of societal service, focused on the prevention of (re)admission and accelerating discharges.

Social psychiatry cannot exist without aftercare nurses. They visit and control patients and provide information to the psychiatrists. The information provided by the nurses plays a critical role in decisions concerning probationary releases, discharges and (re) admissions.

In 1956, the regionalization of extramural healthcare begins and it concludes in 1960. In an organizational way, Limburg is an early adaptor in the formation of the RIAGG's, which takes place in 1982.

By the end of the 1960s, changes with respect to content also become visible. The population of aftercare patients, which can be defined as young, chronic patients who need intensive care increases. A new type of patient also appears; a group with what is known as "psycho-social" and life problems. The activities within the social psychiatric domain shift from aftercare towards precare. The appearance of a new professional group, the psychologists, makes an end to the hegemony of psychiatrists and nurses and contributes to the advanced treatment-orientation of social psychiatry. After 30 years the aftercare has seen better days.

The developments in social psychiatry in Limburg, in many ways are no different than the developments that took place in other parts of the country, although developments are not completely the same everywhere. There are significant differences between the cities and provinces as well as between the cities and provinces themselves. The main difference is that in Limburg, developments begin later and are slow moving for a longer duration. There are a couple of reasons for this.

Especially in the fast-growing cities - what is now called 'big city problems' are substantial and recognizable. Initiatives in the area of mental hygiene and pre and aftercare are urgent. The urgency is bigger than in Limburg, where the problems, against the background of a more homogenous population and the religious based societal connections are less urgent. The cities have, unlike the smaller cities and villages in Limburg, a direct financial interest in preventing or reducing admissions of relatively large groups of patients. They can, because they are bigger players in the social psychiatric domain, take a stand, in any event, more so than in Limburg the Catholic Green Cross Association. Fiscal funding of the pre and aftercare services is in Limburg, and also in other regions outside of the cities, for a longer period, hindering the development of social psychiatry. Change occurs with the introduction of the national funding in 1961 and completes with the funding of social psychiatry through the AWBZ in 1971.

The slow development of social psychiatry in Limburg can also be explained by the continuous shortages of psychiatric manpower. This is partly the result of limited finances, partly the result of the social psychiatry's low status and partly the 
result of a shortage of psychiatrists in general, with or without a Catholic background. In 1957 the St. Servatius institute hires its first neurologist. Until this time only doctors with psychiatric experience are employed at the institute. The attitude of the institutes contributes to the late start up of aftercare services. St. Anna's management does not see a leading role and only wants to cooperate by making a psychiatrist and nurse available to the consultation bureau. The small number of referrals from institutes to aftercare services can be seen as proof that there is little enthusiasm.

The influence of the Roman Catholic Church, a prominent figure in Limburg at that time, is unsure. The Limburg clergy, board members of the Catholic Green Cross, plead several times for mental health care in the province. Whether or not the church has any direct influence on the development of social psychiatry and if so, can it be connected to its slow start and slow development, remains unclear.

The regionalization of extramural psychiatry (1960) can be considered special. In relatively homogeneous Limburg, there are no dominant cities. Two Catholic institutes, St. Servatius and St. Anna and the Catholic Green Cross, play a major role. Within this institutional emptiness, a modern infrastructure for extramural mental healthcare develops with relative ease. The structure remains when the process of secularization commences and the role of the church and religion diminishes. From here on the extramural healthcare in Limburg takes the lead when compared with the developments in other parts of the country.

\section{The mental health care from 1985 until present}

The strong growth of the mental health domain continues after the formation of the RIAGG's. This applies to intramural and extramural care as well. In 1982, seven out of 1,000 inhabitants request help. This number grows to 17 per 1,000 inhabitants in 1997. In 1997 the year prevalence of the number of clients in the Netherlands is estimated at more than one million. A large majority of these clients stem from the RIAGG's. In 2006 one and a half percent of the population, approximately 247,500 persons, are registered. As the number of patients increases so does the number of personnel. In 1985 there are some 35,000 full time equivalents. This continues to grow - 45,400 in 1996 - in the years thereafter, but it is not only growth that characterizes mental health care.

With respect to content there are other important developments. At the RIAGG's psychotherapy becomes more important. Psychotherapists, including psychiatrists that are educated as such, are now the leading professional group. This also holds true in psychiatric hospitals and psychiatric departments located in general hospitals, although less than at the RIAGG's. 
The trend to hold onto patients for as short a time as possible continues in the institutes. As a result of the number of discharges increases and the demand for aftercare increases.The RIAGG's are unable to meet the demands and hospitals expand the outpatient departments. In spite of the expansion there is not enough continuity of care. The outpatient departments develop quickly into departments where broad extramural care is offered and they look more and more like the adult care departments at the RIAGG's

In the 1980s biologically oriented psychiatry, which has been for a long time unpopular but has never disappeared, has a revival. This revival is stimulated by the availability of effective psycho-pharmaceuticals. This adds to the fact that by prescribers as well as patients, along with psycho-therapy, medication is accepted as a satisfactory method of treatment.

For the psychiatrists the growing medical-biological orientation means that their position gains strength. They are not only active in the field of psychiatric diagnosis but also in the field of psycho-therapy and the treatment by medication, which covers the entire therapy work field. Once again, especially in the RIAGG's, they have a steering role in the position of treatment coordinator or team leader. In the intramural domain, their role has never really been at risk.

During the 1990s the character of psycho-therapy begins to clearly change. Many familiar forms of fundamental and insight giving treatment are now replaced by more pragmatic, problem-oriented working methods. This change can be explained in two ways. The first is that "old style" psychotherapy is too exclusively applied to the young, well-educated and motivated persons requesting help. From the start the criticism of the RIAGG's is that the group that does not possess these characteristics receives too little attention. What is also important is that the heightened insight that the more person-oriented method of psycho-therapy is insufficiently effective for both groups of patients and that any rational working methods such as cognitive therapy are more effective. Evidence-based working in mental health care also becomes a directive starting point. The "old-style" psychotherapy as a prominent method of treatment has seen her best days. Many psychotherapists set up their own practices. They are replaced by psychiatrists, psychologists NOT psycho-therapists and social psychiatric nurses.

Throughout the years government influence on mental health care continues to grow. This can be identified in the examples of two policy memoranda: the Structuurnota Geestelijke Gezondheidszorg (1974) and the Nieuwe Nota Geestelijke Gezondheidszorg (1984).

The central theme of government influence is the establishment of an integrated, complete comprehensive and accessible system of care services, which is regionalized and manageable. Continuity of care is an important starting point. These issues are described in greater detail in the policy memorandum Beleidsvisie 
Geestelijke Gezondheidszorg (1999). Announcements are made concerning the strengthening of the first-line (free accessible care without referral), the conclusion of the RIAGG's and the psychiatric hospitals as distinct services and a reshuffling of the professional structure. The focus is on such issues as admission, substitution, the establishment of care chains to improve the continuity of care, demand driven instead of supply driven care and strengthening the position of the customer.

The final point is already apparent since the establishment of the Special Admission to Psychiatric Hospitals Act (BOPZ) in 1992 and the Medical Treatment Agreement Act (WGBO) in 1995. Aside from the introduction of the regulations the role of the customer and/or their representatives, begins to increase. This becomes evident by the influence of the Ypsilon Foundation for family members and others associated with schizophrenic or psychotic disorders. A final example of the changing role of the customer is the inclusion of (ex) patients as expert witnesses in the process of patient education and the development of treatment programmes and protocols.

Government involvement leads to a growing organizational cooperation between the psychiatric institutes and the RIAGG's. The merger between intra- and extramural institutes that started in the beginning of the 1990s continues and ten years later, in 2003, the dismantling of these large institutes is announced. Mental health care will be organized in two layers. In the first layer, the integrated first-line care, the larger section of persons with a psychiatric disorder will receive short-term generalised care, provided by the family physician, the social worker or the first-line psychologist. The second layer, specialized ambulatory and clinical mental health care, is for persons with serious and complex problems who are not suitable for first-line treatment. From the 60,000 persons necessitating long-term care and assistance, 25,000 of these require intensive care as a result of social and behavioural problems. The goal is not to cure or make them better, but to educate them to cope with their limitations that result from their disorder.

The government policy is, as with somatic health care, focussed on what the Minister referred to as "curing the illness and, as much as possible, limiting the damaging effect of it". To stimulate the coherence of the care framework and the effectiveness of the entire curative care, financing, of what in terms of the Minister is referred to as "Medical Mental Health Care", is transferred (January 1, 2008) from the AWBZ to the Health Insurance Act (ZVW). As a financial model in medical mental health care, just as in somatic care, the diagnosis treatment combinations are introduced. From then on psychiatric problems are put in line with somatic problems and are characterized as medical in the literal sense of the word. 


\section{Social psychiatric nursing from RIAGG's inception}

With the growth of the social psychiatric domain, the number of social psychiatric nurses also grows. In 1986, there are 761 fte's and in 1995, 1,065. From the estimated 1,544 active social psychiatric nurses in the second-half of the 1990s, 87 percent is employed at the RIAGG's. The others are employed at psychiatric hospitals, consultation bureaus for alcohol and drug problems and psychiatric departments located in the general hospitals. In 2008 there are approximately 2,580 social psychiatric nurses. The expansion of this profession is only one aspect of its development. This development is strongly influenced by the developments taking place within extramural healthcare and related circumstances.

The heightened focus towards psychotherapy, following the commencement of the RIAGG's, executed to treat the growing number of patients with psycho-social and life problems, leads to a more psychotherapeutic orientation of nurses, or at least, to the adaption of psycho-therapeutic insights and working methods. They begin to focus more, but not completely and not exclusively on the abovementioned patient category. Therefore, the attention for the initial group, the (non) chronic patients with a history of institutionalization, later expanded to a group of persons with low performance status, and eventually in combination with behavioural problems, decreases. The patient in his living environment is no longer the nurse's central focus of attention, but the patient visiting the RIAGG. In the mid1990s, about 60 percent of nursing contacts take place at the RIAGG locations. 60 Percent of the nursing staff has contact with patients, twenty percent with the patient's partner and ten percent with family members. Six percent of the nursing staff works with client groups.

The clients and their problems are diverse. It not only concerns people with psychiatric problems and disorders in a limited sense, but also persons with, for example, a limited social network, employment, housing, financial, relational and existential problems, issues caused by maltreatment and violence, problems expressing themselves clearly and with a relatively low education level. Chronic patients make up approximately fifteen percent of the nurses' client base. Compared with the other RIAGG personnel, the nurses do not focus on the treatment of people with apparent psychiatric problems, but more specifically on groups with social and societal problems. The core responsibilities of these nurses are mainly the intakes, consultation hours and reception shifts, crisis intervention and treatment and counselling. Direct patient care is primarily to offer help and structure and consultation in material and non-material problems. Secondary are issues such as network development and support, care coordination and activities regarding management and intake of medication. 
Until the 1990s, social psychiatric nurses are the only nurses to play a substantial role in the social psychiatric domain. Changes occur with the start of intensive psychiatric home care. From the psychiatric institutes, institute nurses provide shortterm care, focused on Activity of Daily Living ADL-functions, medication usage and providing advice to family members on how to handle the patient with a goal to limiting or preventing re-admissions.

Around 2000, other nurses such as those with an educational background as Nurse Specialists GGZ or with Master of Advanced Nursing Practice or Evidence Based Practice, become active in the social psychiatry domain. The professional education for social psychiatric nursing is terminated in 2002. Before the last diplomas are awarded in 2007, the programme "Post HBO-SPV" is launched in cooperation with some universities of applied sciences and initiated by the former Dutch Association of Social Psychiatric Nurses. The association considers this programme as the [new] professional education. Graduates from other programmes, and only under strict conditions, are registered in the SPV register, which is established by the professional foundation in 2003. The HBO-SPV programme educates professionals to work with groups that receive little or no attention or support and are at risk of dropping out, are living in social isolation and are in many ways vulnerable.

Establishing the course goals is linked with a development of the professional group, which becomes clear in the early 1990s and can be summed up as attention towards social psychiatric course of thought. Appeals are made to see the patient as a part of his/her societal and social cultural context, to involve this context as part of the treatment and to work demand oriented rather than diagnosis oriented. Social psychiatry is positioned across from what is called "result oriented" and "instrumental technical care" and is more than only extramural psychiatry.

The social psychiatric nurses not only focus on caring for the vulnerable and the underprivileged. Since the beginning of the decennium, the nurses are actively involved in first-line healthcare. RIAGG personnel are appointed to strengthen the first-line through consultation. The nurses provide a major part of these consultations: 75 percent of the total of 10,000 in 2004.

Support of the first-line is formalized in 2001 with the establishment of the Regional Support Structures (Regionale Ondersteunings Structuren). In addition, the position of assistant to family doctors (POH-GGZ) is established in 2008. Social psychiatric nurses and social workers are mentioned as candidates. In the meantime the professional foundations of both of these professional groups develop a performance profile POH-GGZ. The position of NVSPV-V\&VN with regard to the performance profile indicates that the association strives to extend and consolidate the role of social psychiatric nurses in the first line. For the time being it is uncertain whether and how the extension of the domain will continue. 
There is also uncertainty about the consequences of the planned decategorization of the second-line mental health care. Social psychiatric nurses could be, as it now looked, employed in the specialized mental health care sector as part of the approximate 60,000 patients with complex problems. The report 'Zorg van velen', from which the Minister of Health is advised to choose contextual care, is tailor-made for this aspect. The question is whether or not this will happen and if yes, will care be structured according to the wishes of the nurses? Not excluded here is that what nurses call "instrumentalization and protocolization" will also occur. For the time being, the nurses do not select this.

It is conceivable that extramural mental health care nurses will be active in three sub-domains of extramural healthcare: generalized first-line, and in two parts of the second line - the part that focuses on treatment and the part that focuses on care and guidance. The nursing group, formed by those who refer to themselves as social psychiatric nurses, will decrease. Officially, the title "social psychiatric nurse" no longer exists and it is doubtful whether nurses with different educational backgrounds will call themselves that. The domain of social psychiatry no longer exists under this name and the title "social psychiatrist" is rarely used. Why then, should the social psychiatric nurses be an exception? It is difficult to say whether or not, as a consequence, social psychiatry's course of thought will disappear.

\section{Feedback to the theory}

The following diagram outlines the most important developments in the social psychiatric domain and in the most important professions that are active within it. The diagram indicates professionalization ideas according to Abott and provides more clarity in terms of Benson's related ideas on intra and inter-professional coherence.

The claim of social psychiatry until the early 1960s is simple: Keeping people with psychiatric problems out of the institutes. At first this is achieved by the provision of aftercare. Later at the beginning of the 1950s precare is included. The content of the pre- and aftercare does not differ much. It concerns a limited scale of activities in which control and structure are essential. The way in which to realize this is the great number of house calls carried out by the nurses and the consultation hours headed by the psychiatrists.

The claim of social psychiatry is realized by two professional groups that are active within the domain. They are the only players. The domain's claim is the same as the claim made by the two professional groups. They work closely together and their relation is clear-cut. The small numbers of psychiatrists who work mostly on a part-time basis are the front runners and have the final responsibility, the greater number of nurses who work mostly on a full-time basis carry out the work within 


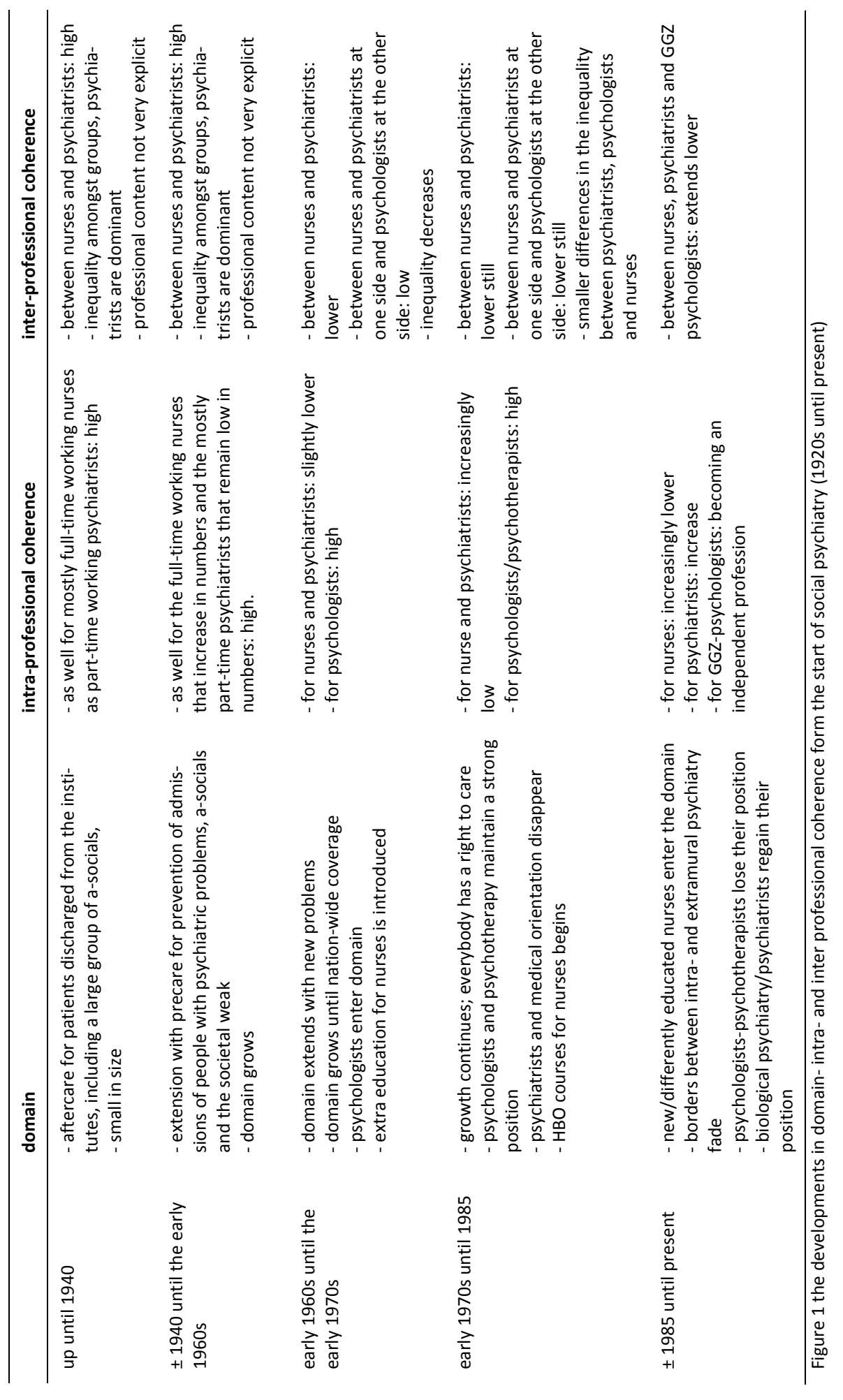


limitations set down by the psychiatrists. The limits are flexible and for a large part, the nurses are able to decide themselves on how the tasks shall be carried out. Personal insight and experience are equally important for the nurses and psychiatrists alike. There is no such thing as a knowledge area of social psychiatry or social psychiatric nursing. The fact that nurses can, from 1937 onwards, participate in a professional aftercare education does not change this.

The claim proves successful. Patients are kept out of the institutes without too many problems. Patient numbers slowly increase. The significance of this materializes through partial financing in 1961. The financing and the related personnel requirements can also be viewed as governmental interference. The government uses the financial conditions and influences, not so much the content, but at least the structure and organisation of the Social Psychiatric Services. A new player enters the social psychiatric domain, whose influence becomes more evident in the early 1970s. Thanks to the financing, services continue to grow and focus on clients with less serious or acute psychiatric problems, clients that benefit from long-term support and guidance.

In regards to the actual work of psychiatrists and nurses, the extension of care does not pose any great consequences. The claim doesn't yet change. This also applies to the intra- and inter-professional coherence. Coherence is high within and between the groups. There is agreement about the idea that aftercare for institutional patients is the core of the activities. At the moment that a new patient category comes to light (1950s), the patient group has never been institutionalized, the precare and prevention of admissions becomes a new social psychiatric position that gains acceptance of both groups. This is an indication of both intra and interprofessional ideological consensus. The ideology scarcely develops or is differentiated. In more common terms, pertains to care, guidance and support.

There is also consensus within and between the two groups about their role and related tasks to be filled or performed. This is also an indication of intra as well as inter-professional domain consensus. The fact that within and between both professional groups daily work responsibilities are executed apparently without problems is an indication for coordination and positive evaluation of each other's work. At first there is little thought behind this and not much is worked out officially. The hierarchy between the part-time psychiatrists and the full-time nurses is clear. This is emphasized by the fact that the psychiatrists take the lead in the aftercare education of nurses. For a long time, the psychiatrists also decide on the educational content. The daily work routine of the nurses, whilst keeping within the hierarchical structure, allows for a broad scope in which to organise and perform their tasks in accordance to their own ideas. In the Netherlands, both professional groups from the social psychiatric domain, remain throughout the third and forth decades, in terms of intra- and inter-professional coherence, in balance. 
Changes occur during the start of the 1960s. The domain receives an impulse from the National Subsidy Ruling for Social Psychiatric Services. Important is the arrival of psychologists who play a significant role in the social psychiatric domain. Also important is the anti-psychiatric movement. The influence of social, societal and inter-personal factors in regards to existence and resolving psychiatric, psychosocial and life problems gains strength. Under this influence, the claim of social psychiatry changes and differentiates. Focus is not only on the prevention of admissions, but also on prevention, treatment and solving or at least, managing problems.

Amongst these changes, new approaches begin to appear and within a relatively short period, psycho-therapy treatment methods achieve importance. Preand aftercare with position control, guidance and support move to the background, but do not disappear altogether. The changes of the domain claim also takes place in the claim of psychiatrists and nurses. At first this moves along slowly and does not infiltrate the entire body of the professional groups. An example of this is the growing interest amongst nurses of psycho-therapy oriented working methods and education. The high intra- and inter-professional coherence in and between the two professional groups is no longer obvious and is slightly lower than in the earlier years. The coherence between nurses and psychiatrists at one end and psychologists at the other can be considered as low.

At the beginning of the 1970s these changes become more evident. The fiscal support for social psychiatry by the AWBZ from1971 onwards provides a major impulse to the sector. This method of financial support can be viewed as societal recognition of social psychiatry's claims of success or, at least, the recognition of its importance. This fiscal support stimulates further growth.

Against a background of changing ideas about the existence and treatment of psychiatric problems, in combination with the arrival of a new category of patients, built up by people with what is known as psycho-social and life problems, the social psychiatric claim noticeably changes. The focus shifts from generic support throughout pre- and aftercare, towards extramural psycho-therapeutically oriented treatment of psychiatric patients and people with psycho-social and life problems.

Many of the nurses follow this new orientation. The profession's claim becomes differentiated. One part focuses on the new group of patients and specializes in psycho-therapy while another part continues with their previous work. Inside the professional group a certain kind of divergence begins about the agreement of the work field, the tasks to be carried out and the knowledge and competences required. The same applies to the psychiatrists.

The interference of psychiatrists in changing nursing education, illustrates the existence of the first group, at least for a part, of innovative ideas about how social psychiatric medical practice and social psychiatric nursing practice, should be structured and organized. The interference of psychiatrists in nursing education also indicates that a certain kind of hierarchy still remains between both professional 
groups. However, nurses remain highly autonomous in the structuring and organization of their work.

Within the social psychiatric domain, in both groups of psychiatrists and nurses as well as between the both groups, a decreasing yet reasonable amount of professional coherence can be seen. Coherence is low between the two groups and the rising professional group of psychologists. The inter-professional coherence within the psychologist group is high.

Growth of the domain continues after the initiation of the RIAGG's. The claim of what less often is called social psychiatry and more often extramural psychiatry changes rapidly. The focus points include prevention and extramural treatment of psychiatric, psycho social and life problems. The most significant working method is psycho-therapy, especially long-term insight-providing forms of psycho-therapy. With the increasing role of psycho-therapy and psycho-therapeutically oriented working methods, the RIAGG consulting room becomes the workplace. The specific characteristic of social psychiatry, interventions taking into account and making use of the patient's immediate surroundings disappear, except from crisis intervention, into the background. This continues throughout the years that biological psychiatry gains ground and the long-term forms of psychiatry are replaced by more pragmatic problem-solving methods. The claim of psychiatrists grows and in line with it, the intra-professional coherence of the group also grows. The importance of the claims by psychologists and psycho-therapists decreases at the same speed. They begin to leave the RIAGG's in large numbers. A new generation finds employment as firstline psychologists.

There is no unequivocal claim coming out of the nursing group. The ideas continue to be divergent. In the first place there is the group of patients on which attention should be focussed: the underprivileged group of chronic and non-chronic patients against patients with relatively minor psychiatric and psychological problems. Next there are the activities that must be carried out for patients: guidance and support vs. treatment/ psycho-therapy. And finally, there is divergence within the vision about which activities are necessary: the necessity to include the social context in patient approach vs. the individualized approach. In other words, domain and ideological consensus are constantly under pressure. The same can be said for the positive evaluation of one another's work and thus, in summary, the intraprofessional coherence.

The group of social psychiatric nurses active in the domain of extramural mental health (2008) can be divided into three groups concerning domain and ideological orientation. This is an analytical division: in fact the same nurses are active in different settings. The first group focuses on working with (non-) chronic patients with complex problems. The group chooses for what is called the "rehabilitation" approach. The goal is not healing, but to assure as satisfactory a human existence as possible, taking into account and using the social context. The second group focuses 
on the usual RIAGG work. This can be described as a low to moderate complex guidance of people with moderate to serious psychiatric and psycho-social problems.

The third group is currently active in consultation of first-line care and focuses on the continuation of it. The activities are both diagnostic and consulting. One matter that makes it more complex is that extramural mental health care is no longer the exclusive work field of social psychiatric nurses, and that differently educated nurses are now actively involved.

The nurses' claim is more diversified than ever. The conclusion can be drawn that there is currently less domain and ideological consensus amongst the group of social psychiatric nurses than there was previously. Against a background of an assumed relationship between these two dimensions and the dimensions positive evaluation of one another's work and work coordination, the conclusion can be drawn that the latter two will not be high. The conclusion, as a consequence, applies to the level of intra-professional coherence within the nursing profession as a whole.

\section{Remarks according to methodology and content}

With reference to this study some methodological and content remarks can be made according to reliability and validation. ${ }^{541}$ Reliability refers to the absence of coincidental distortions; validation means the absence of systematic distortions.

An important indicator of reliability is the eventual virtual reproducibility. In principle, this study can be reproduced using the same methods since the research situation has not changed. The only exception is the interviews. Taking into account the ages of the nurses, it is most likely that not all of the nurses that provided information in Chapter 7 are still reachable. Another aspect of reliability is the intersubjective agreement between the members of the research team. This study guarantees the agreement in different ways. Throughout the project, regular discussions were held about the project status between the researcher and research supervisors. This is also called 'argumentative reliability'. During the preparation and execution phase, described in Chapter 6, of the status research, interrater agreement is guaranteed. In this case there were two researchers and two reviewers. Regular checks were in place to make sure that any information uncovered and the interpretation of it was the same.

Literature, archives, patient records and interviews are used throughout the study. This method of resource triangulation adds to the validity. Accomplishing validity is underlined by the occurrence of data saturation both in and between the different types of resources.

\footnotetext{
${ }^{541}$ Definitions and details can be found in Maso, I., \& Smaling, A. (1998). Kwalitatief onderzoek: praktijk en theorie. Amsterdam: Boom, chapter 4, 64-86.
} 
It is remarkable that there is little information gathered about the social worker group. Remarkable in that it is a professional group that is regularly associated with the social psychiatric nursing group. It is plausible that initially for numerical reasons little contact is made with one another. The number of social workers in extramural psychiatry (1975) is an estimated 91 out of 491 social psychiatric nurses. ${ }^{542}$ A section of the social workers, part-time and full-time, are active in the Child Guidance Clinics and Centres for Marriage and Family Problems. Twenty years later the number of social workers and nurses are about 600 against $1,125 .{ }^{543}$

During the period 1989-1994, the number of social workers decreases by 23 percent and the number of nurses increases by 40 percent. The reason for this is that social work, by its psycho-therapeutic orientation, looses tasks from about 1970 that are taken over by the nurses. ${ }^{544}$ Obviously the professional claim between the nurses and the social workers differs, which is the reason they focus on different types of clients, different working methods and for this reason, they do not meet.

The decrease of social workers continues into the 1990s. "By the employers in the GGZ both professional groups are looked at as equal and interchangeable, at the work floor, however always a choice for SPVérs is made". ${ }^{545}$ The social workers have, for at least a part, ideas about tasks that are not in line with the ideas of others. "They see themselves also in the role of (psycho) therapists, specialized in the field of psycho social care, mainly for couples and families" ${ }^{546}$ The social workers are insufficiently different from psychologists and psycho- therapists and for these disciplines "a position as such for social workers is hardly acceptable". ${ }^{547}$ In other words: the RIAGG social workers did not succeed in holding on to their claim. In other places such as general social work and in the personnel administration at companies and institutes, they do succeed. Here they focus on the application of regulations, on labour conditions and the mediation with individual problems.

Psychiatrists have a significant influence on the development of the social psychiatric nursing group. The emphasis on the nurses in this study to a certain degree underexposes this influence. In other words: a more psychiatrist-focused study on conceptions and aspects of cooperation could lead to a differentiation and completion of the developed view of the course of events in everyday practice of social psychiatry, so strongly influenced by nurses and psychiatrists

\footnotetext{
${ }^{542}$ Romme, M.A.J. (red.) (1978). Voorzieningen in de geestelijke gezondheidszorg: een gids voor consument en hulpverlener. Alphen aan den Rijn; Brussel: Samsom, 24.

${ }^{543}$ Hutschemaekers, G., \& Neijmeijer, L. (1998). Beroepen in beweging: professionalisering en grenzen van een multidisciplinaire GGZ. Utrecht; Houten: Trimbos-Instituut; Bohn Stafleu Van Loghum, 181.

544 Ibidem, 58.

${ }^{545}$ Ibidem, 215.

${ }^{546}$ Ibidem.

${ }^{547}$ Ibidem, 126.
} 


\section{Conclusion}

In 2003, the Minister of Health has announced that the care for a group of approximately 60,000 chronically ill patients will become a part of what will be called "specialized mental health care". Obviously the social psychiatry domain does not disappear, but, without being named as such, it takes another form. Obviously there is a relatively small group of people, who for different personal and societal reasons are unable to cope and require care.

There are two reasons for the continued availability of this care. The first reason is the pressure that the group (not everyone involved continued or at the same volume) lays on their direct living environment and the society. Having a son or daughter with a double diagnosis brings about more grief, care and fear than most parents are able to cope with and think possible. The unpredictable, sometimes destructive, behaviour of some patients e.g. those with a border-line personality disorder, can be very de-regulating for care or cure oriented services and it costs a lot of energy and money. The second reason has to do with the burden and limitations that many persons from this group experience. The absence of employment and income, a good home, difficult or no contacts and relations, for a longer period of time and often in combination with one another, is to put it mildly, a demorali-zing prospect.

It is wise and humane to continue care for this type of group. An important criterion is that care maintains a low threshold and be easily accessible and open. It is already apparent that patients find their way to social psychiatric nurses, working in family physician practices, on their own. Aside from the way in which the mental health care domain is organized, patients obviously require (although they will not express it this way) experienced personnel who are able to assess which type of care is required and how this care should be administered. This type of care, to express it in terms of Orem's Self-Care Deficit Theory of Nursing varies from "supportive educative" and "partly compensatory" to "wholly compensatory" activities. ${ }^{548}$ Historically these kinds of activities are part of the domain of nursing. Well educated nurses are qualified to carry out this work. What they are called is of secondary importance.

${ }^{548}$ Orem, D.E. (2001). Nursing: concepts of practice. St. Louis: Mosby, 350. 


\section{Dank}

\section{Veel dank aan}

- Prof. dr. Hans Philipsen, eerste promotor, voor de geïnteresseerde en stimulerende betrokkenheid bij dit, zijn $60^{\text {ste }}$, promotieonderzoek en voor de gewaardeerde inbreng in aangelegenheden van professionele en aangrenzende aard over een periode van 30 jaar;

- Prof. dr. Ad Knotter, tweede promotor, voor de uitdagende en opbouwende inbreng;

- Dr. Jos Diederiks, copromotor, voor de geëngageerde en motiverende betrokkenheid bij dit project.

\section{Dank ook aan}

- Prof. dr. Ad Knotter, in de functie van directeur van het Sociaal Historisch Centrum voor Limburg in Maastricht voor het verlenen van toegang tot de archieven;

- de medewerkers van het Sociaal Historisch Centrum voor Limburg, in het bijzonder de heer Henk Hondius, voor de altijd zo vanzelfsprekende dienstverlening;

- Drs. Piet Meertens voor, alweer, de hulp bij de dataverzameling en de niet afnemende belangstelling;

- de Raad van Bestuur van het voormalige Psycho-Medisch Streekcentrum Vijverdal voor het geven van toestemming tot het verrichten van een haalbaarheidsonderzoek;

- mevrouw P. Boren-Scholtes (sociaalpsychiatrisch verpleegkundige), mevrouw A. Butter (sociaalpsychiatrisch verpleegkundige), mevrouw $\mathrm{H}$. Willems (sociaalpsychiatrisch verpleegkundige), mevrouw R. Glas (sociaalpsychiatrisch verpleegkundige), mevrouw W. de Reuver (sociaalpsychiatrisch verpleegkundige), mevrouw K. van Tellingen (sociaalpsychiatrisch verpleegkundige), mevrouw drs. M. Crolla-Baggen (maatschappelijk werker/systeemtherapeut) en mevrouw drs. A. van

Nooijen Kooij (sociaalpsychiatrisch verpleegkundige) voor de verstrekte informatie tijdens boeiende gesprekken;

- de voormalige Faculteit der Gezondheidswetenschappen, nu Faculty of Health, Medicine and Life Sciences, Maastricht University, voor het faciliteren van dit onderzoek;

- collega's, met name de 'lunchtafel', van de voormalige capaciteitsgroep, later sectie Verplegingswetenschap, nu Vakgroep Verpleging en Verzorging/Department of Health Care and Nursing Science, Faculty of Health, Medicine and Life Sciences, Maastricht University; 
- Marianne Tilly voor de hulp bij het verwerven van literatuur, het beheer van het literatuurbestand en voor editoriale ondersteuning;

- het administratiebureau van de voormalige Nederlandse Vereniging voor SociaalPsychiatrisch Verpleegkundigen NVSPV voor het prompte reageren op vragen;

- Dr. Roos-Marie Bal voor het commentaar bij een conceptversie van het manuscript;

- Lori Mees voor het verzorgen van de Engelse samenvatting;

- de leden van de beoordelingscommissie voor de bereidheid deel uit te willen maken van die commissie. 


\section{Curriculum Vitae}

Gerard Joseph Antonius Maria Brouns, geboren 22 maart 1950 te Eygelshoven

1956-1961: R. K. Jongensschool St. Joannes de Doper, Eygelshoven

1961-1962: Onze Lieve Vrouweschool, Heerlen

1962-1963: Voorbereidende Klas St. Antonius Doctorcollege, Kerkrade

1963-1968: Handelsschool/HAVO, St. Bernardinuscollege, Heerlen

1968-1971: opleiding ziekenverpleging B, Psychiatrisch Centrum St. Servatius, Venray

1971-1972: verpleegkundige, Psychiatrisch Centrum St. Servatius, Venray

1972-1974: Hogere Opleiding (H.O.), afstudeerrichting management, Katholieke Hogere School voor Verpleegkundigen, Nijmegen

1974-1979: leidinggevend verpleegkundige, opname-afdeling, Psycho-Medisch Streekcentrum Vijverdal, Maastricht

1979-1991: capaciteitsgroep Klinische Psychiatrie, Rijksuniversiteit Limburg, Maastricht (onder meer gedetacheerd als afdelings- en clustermanager bij het PsychoMedisch Streekcentrum Vijverdal te Maastricht en bij de afdeling psychiatrie van het Academisch Ziekenhuis Maastricht)

1991: doctoraaldiploma Gezondheidswetenschappen, afstudeerrichting Verplegingswetenschap, Universiteit Maastricht

1991-heden: universitair docent bij de capaciteitsgroep, later sectie Verplegingswetenschap, nu Vakgroep Verpleging en Verzorging/Department of Health, Care and Nursing Science, Universiteit Maastricht (onder meer programmaleider van de deeltijdopleiding Verplegingswetenschap, programmaleider van de opleiding Master of Nursing Science te Aarau, Zwitserland, 1996-1999 en 2004-2006)

2008-heden: Onderwijsinstituut Faculty of Health, Medicine and Life Sciences Maastricht University (internationalisering onderwijs m.n. Duitse taalgebied).

Voormalig redactie(raads)lid van Verpleegkunde; Nederlands-Vlaams wetenschappelijk tijdschrift voor verpleegkundigen.

Mede-oprichter en voormalig voorzitter van de Vereniging voor Consultatieve Psychiatrische Verpleegkunde, nu V\&VN Consultatieve Psychiatrische Verpleegkunde. Founder van de International Orem Society for Nursing Science and Scholarship. 